WSRC-TR-99-00310

\title{
Hydrogeological Analysis and Groundwater Flow for C-Reactor Area with Contaminant Transport for C-Reactor Seepage Basins (CRSB) and C-Area Burning/Rubble Pit (CBRP)(U)
}

Gregory P. Flach, Mary K. Harris, Robert A. Hiergesell, Andrew D. Smits, and Kelley L. Hawkins

December 1999

Prepared by:

Westinghouse Savannah River Company

Savannah River Site

Aiken, SC 29808

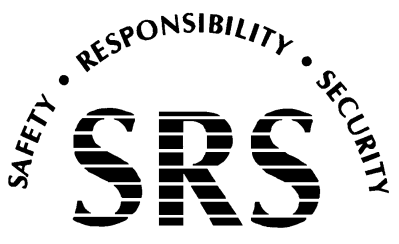

Prepared for the U.S. Department of Energy Under Contract Number DE-AC09-96SR18500 
This document was prepared in conjunction with work accomplished under Contract No. DE-AC09-96SR18500 with the U. S. Department of Energy.

\section{DISCLAIMER}

This report was prepared as an account of work sponsored by an agency of the United States Government. Neither the United States Government nor any agency thereof, nor any of their employees, makes any warranty, express or implied, or assumes any legal liability or responsibility for the accuracy, completeness, or usefulness of any information, apparatus, product or process disclosed, or represents that its use would not infringe privately owned rights. Reference herein to any specific commercial product, process or service by trade name, trademark, manufacturer, or otherwise does not necessarily constitute or imply its endorsement, recommendation, or favoring by the United States Government or any agency thereof. The views and opinions of authors expressed herein do not necessarily state or reflect those of the United States Government or any agency thereof.

This report has been reproduced directly from the best available copy.

Available for sale to the public, in paper, from: U.S. Department of Commerce, National Technical Information Service, 5285 Port Royal Road, Springfield, VA 22161, phone: (800) 553-6847, fax: (703) 605-6900

email: orders@ntis.fedworld.gov

online ordering: http://www.ntis.gov/help/index.asp

Available electronically at http://www.osti.gov/bridge

Available for a processing fee to U.S. Department of Energy and its contractors, in paper, from: U.S. Department of Energy, Office of Scientific and Technical Information, P.O. Box 62, Oak Ridge, TN 37831-0062,

phone: (865)576-8401,

fax: (865)576-5728

email: $\underline{\text { reports@ adonis.osti.gov }}$ 
WSRC-TR-99-00310

\section{Hydrogeological Analysis and Groundwater Flow for C-Reactor Area with Contaminant Transport for C-Reactor Seepage Basins (CRSB) and C-Area Burning/Rubble Pit (CBRP)(U)}

Gregory P. Flach, Mary K. Harris, Robert A. Hiergesell, Andrew D. Smits, and Kelley L. Hawkins

December 1999

Prepared by:

Westinghouse Savannah River Company

Savannah River Site

Aiken, SC 29808

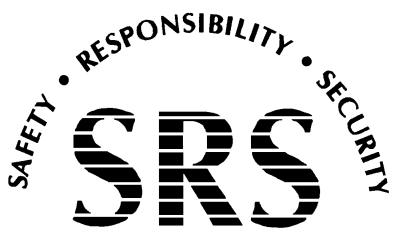

Prepared for the U.S. Department of Energy Under Contract Number DE-AC09-96SR18500 
This page was intentionally left blank 


\section{EXECUTIVE SUMMARY}

A groundwater flow model encompassing approximately $4 \mathrm{mi}^{2}$ within $\mathrm{C}$ Reactor area has been developed. The objectives and goals of the $\mathrm{C}$ Reactor Area groundwater model are to:

- Provide a common hydrogeologic and groundwater flow modeling framework for C Area that can be easily updated as additional field data is collected from waste site investigations.

- Provide a baseline groundwater flow model for use in subsequent flow and transport simulations for remedial/feasibility studies for C Area waste sites.

- Provide baseline transport simulations for CBRP and CRSB that reconstruct historical contaminant distributions and simulate future plume migration from each waste unit.

- Provide a working groundwater flow model for particle tracking and analysis to guide subsequent field characterization activities.

The model incorporates historical and current field characterization data up through spring 1999. The model simulates groundwater flow within the area bounded to the west and north by Fourmile Branch, to the south by Caster Creek, and to the east by a line between Fourmile Branch and the headwaters of Caster Creek. Vertically the model extends from ground surface to the top of the Gordon aquifer. The chosen areal grid is 14,600 by 13,200 feet with a resolution of 200 feet. The model accurately reproduces groundwater flow directions from the CBRP and CRSB, and matches targets for hydraulic head, recharge and baseflow within calibration goals. The hydrogeologic model reflects aquifer heterogeneity as derived from CPT lithologic data.

Baseline transport models were developed for the CBRP and CRSB waste units. The CRSB transport model is based on known tritium releases to the unit and the average plume concentrations and migration path corroborate recent groundwater sampling results. The CBRP transport model assumes that NAPL within the soil serves as the source for the observed TCE plume. The model assumes a TCE flux of $10 \mathrm{~kg} / \mathrm{yr}$ prior to implementation of SVE/AS remedial technology, which is assumed to remove the entire source from the vadose zone. The predicted TCE plume for 1999 travels primarily along the north side of the Twin Lakes drainage at concentrations that are consistent with current CPT data. 
This page intentionally left blank 


\section{TABLE OF CONTENTS}

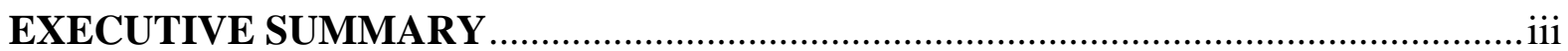

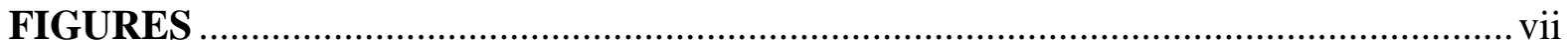

TABLES

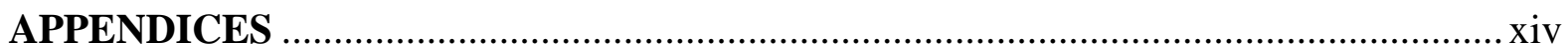

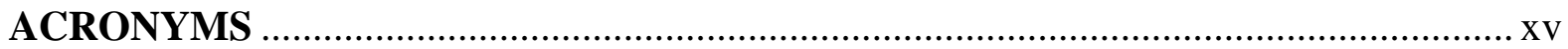

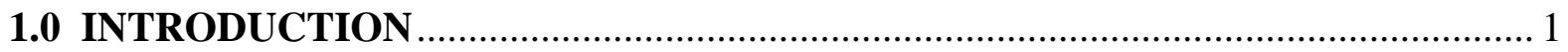

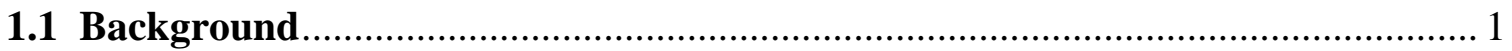

1.2 Modeling Objective and Approach .................................................................... 2

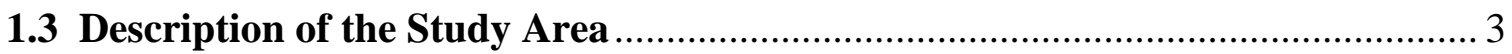

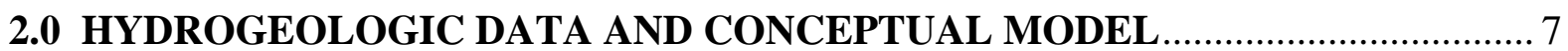

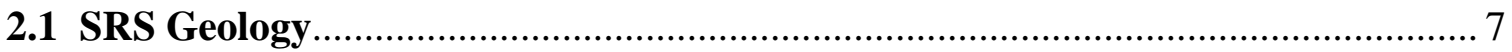

2.2 SRS Hydrostratigraphic Units and Properties ..................................................

2.2.1 Meyers Branch Confining System ……………............................................ 9

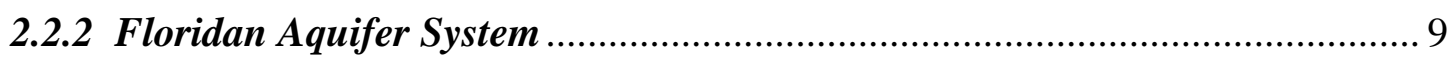

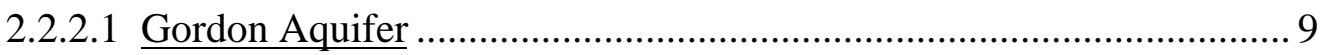

2.2.2.2 Gordon Confining Unit ................................................................... 10

2.2.2.3 Upper Three Runs Aquifer............................................................. 10

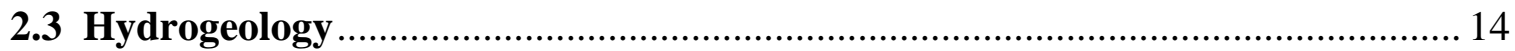

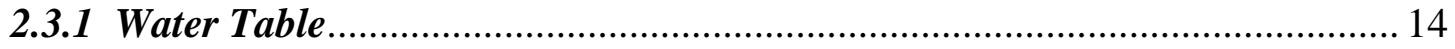

2.3.2 Gordon Aquifer Potentiometric Surface …………….............................. 15

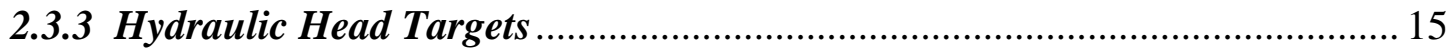

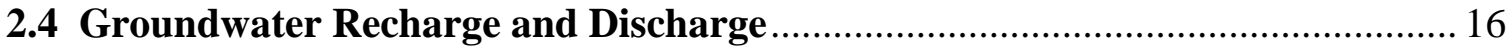


TABLE OF CONTENTS (Continued)

2.5 Conceptual Model of Groundwater Flow

2.6 Hydrologic Properties

2.6.1 Soil Characteristic Curves ............................................................................ 19

2.6.2 Effective (Kinematic) Porosity ............................................................... 20

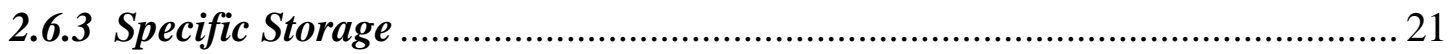

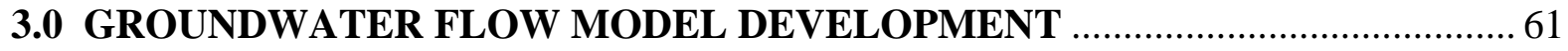

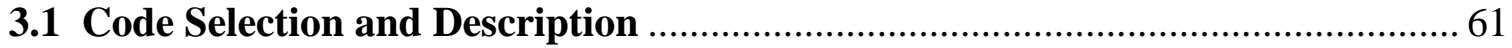

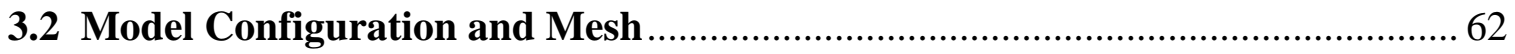

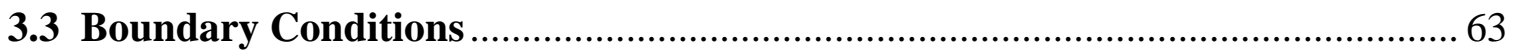

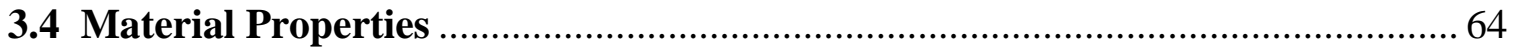

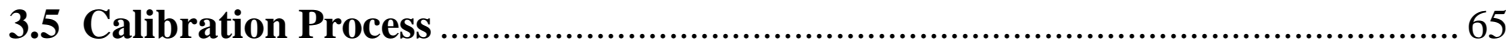

4.0 GROUNDWATER FLOW MODEL RESULTS .......................................... 74

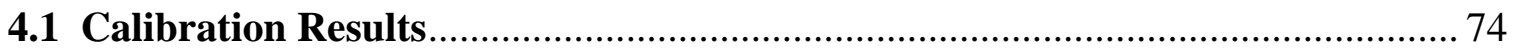

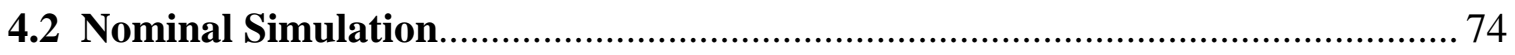

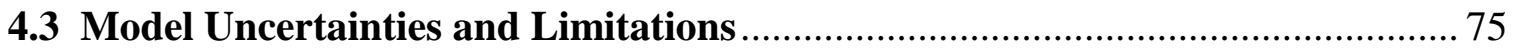

5.0 CRSB AND CBRP FLOW AND TRANSPORT MODELS ................................ 119

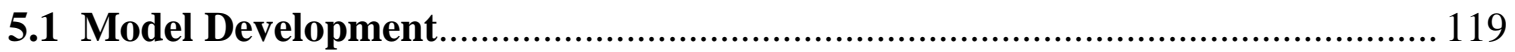

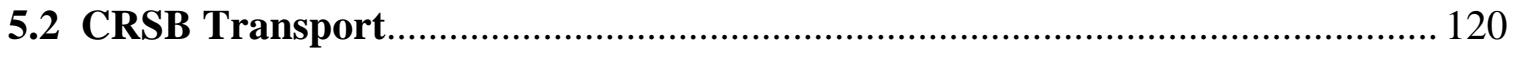

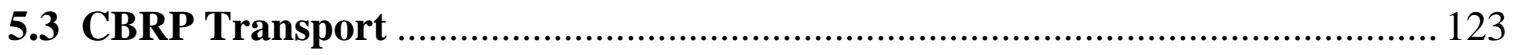

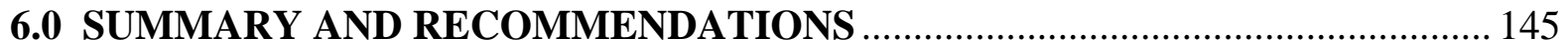

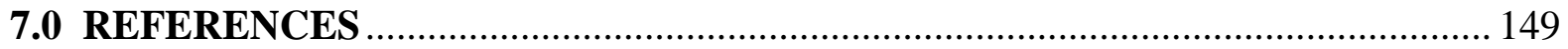




\section{FIGURES}

1-1 Location of the Savannah River Site and Model Area .........................................

1-2 Location of Groundwater Basins at the Savannah River Site .....................................5

1-3 Location of Major Streams and Rivers in Model Area; Geologic Model

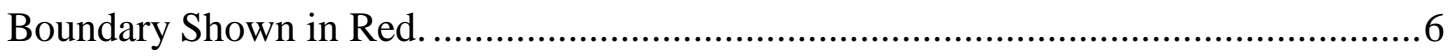

2-1 Comparison of Lithostratigraphic and Hydrostratigraphic Units at SRS .................23

2-2 Locations of Cone Penetrometer Tests and Geologic Cores ....................................24

2-3 EarthVision ${ }^{\circledR}$ Visualization of TCE Concentrations beneath the Model Area ...........25

2-4 EarthVision ${ }^{\circledR}$ Visualization of Tritium Concentrations beneath the Model Area .......26

2-5 Conceptual Hydrostratigraphic Model for C Reactor Area ..................................27

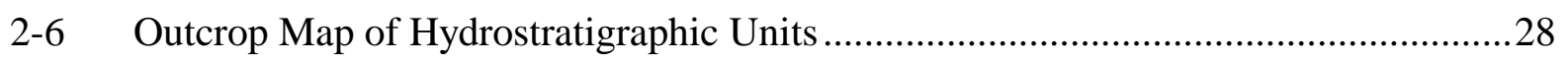

2-7 Altitude-Contour Map of the Top of the Gordon Aquifer .......................................29

2-8 Altitude-Contour Map of the Top of the Gordon Confining Unit .............................30

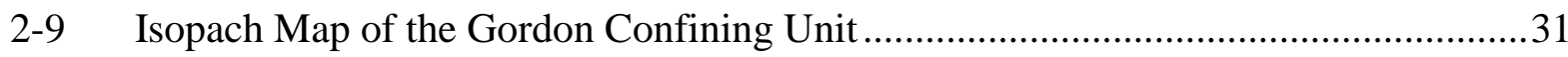

2-10 Altitude-Contour Map of the Top of the Lower Interval of the "Lower"

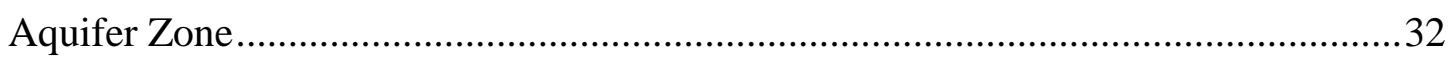

2-11 Isopach Map of the Lower Interval of the "Lower" Aquifer Zone ...........................33

2-12 Altitude-Contour Map of the Top of the Lower Carbonate Interval (CC2) within the "Lower" Aquifer Zone

2-13 Isopach Map of the Lower Carbonate Interval (CC2) within the "Lower"

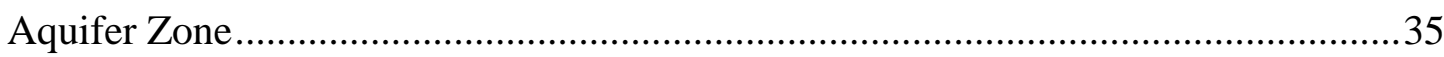

2-14 Altitude-Contour Map of the Top of the Middle Interval of the"Lower" Aquifer Zone. 


\section{FIGURES (Continued)}

2-16 Altitude-Contour Map of the Top of the Upper Carbonate Interval (CC1) within the "Lower" Aquifer Zone

2-17 Isopach Map of the Upper Carbonate Interval (CC1) within the "Lower" Aquifer Zone

2-18 Altitude-Contour Map of the Top of the Upper Interval of the "Lower" Aquifer Zone.

2-19 Isopach Map of the Upper Interval of the "Lower" Aquifer Zone

2-20 Altitude-Contour Map of the Top of the "Tan Clay" Confining Zone 42

2-21 Isopach Map of the "Tan Clay" Confining Zone 43

2-22 Altitude-Contour Map of the Top of the "Transmissive Zone"..... 44

2-23 Isopach Map of the "Transmissive Zone" 45

2-24 Altitude-Contour Map of the Top of the "AA" Interval .......................................46

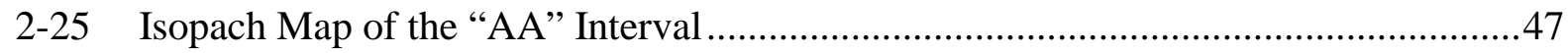

2-26 Altitude-Contour Map of the Top of the "A" Interval .........................................48

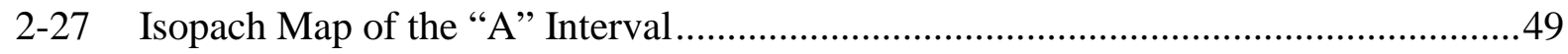

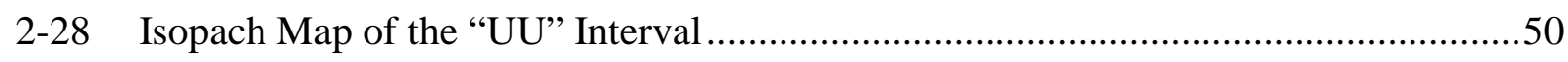

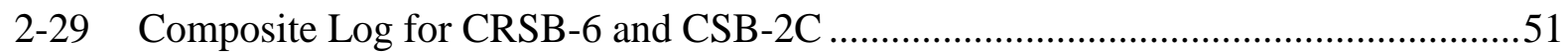

2-30 Regional Water Table Map..........................................................................

2-31 Water Table Map for C Reactor Area.........................................................53

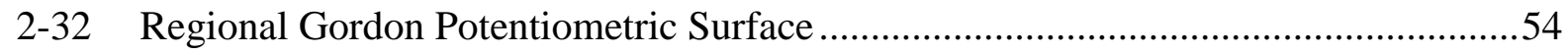

2-33 Locations of Reactor Area Piezometers Installed in 1998 _.....................................55

2-34 Map of Live (Perennial) Stream Reaches as Determined by Field Observations........56 


\section{FIGURES (Continued)}

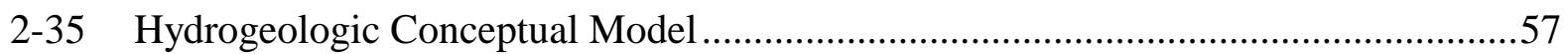

2-36 Approximate Soil Characteristic Curves ……………………................................58

3-1 Plan View of Model Domain and Finite-Element Mesh ...........................................68

3-2 North-South Cross-Sectional Slice through Mesh at CRSB ........................................69

3-3 Three-Dimensional Perspective View of Mesh ......................................................... 70

3-4 Top Surface Boundary Conditions.........................................................................

3-5 Boundary Conditions for Gordon Aquifer between Top and Bottom Nodal

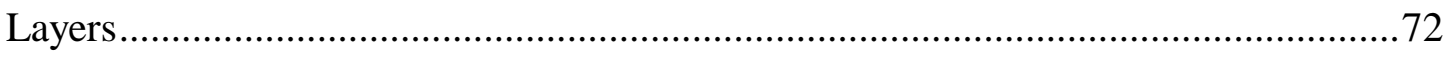

3-6 Boundary Conditions for Upper Three Runs Aquifer between Top and Bottom

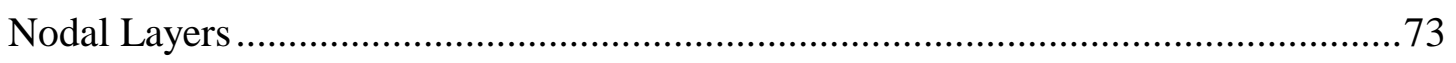

4-1 Simulated Versus Measured Head for each Aquifer Zone .........................................77

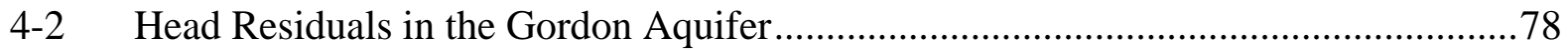

4-3 Head Residuals in the Lower UTRA ………............................................................79

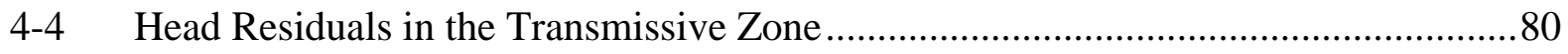

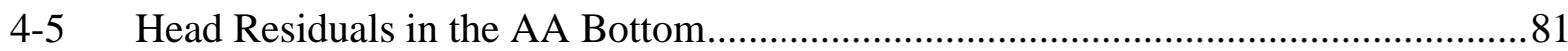

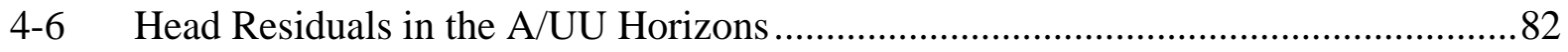

4-7 Hydraulic Conductivities in Element Layer 1 (GAU Except Outcrops).......................83

4-8 Hydraulic Conductivities in Element Layer 2 (GAU Except Outcrops).......................8

4-9 Hydraulic Conductivities in Element Layer 3 (GCU Except Outcrops).......................85

4-10 Hydraulic Conductivities in Element Layer 4 (GCU Except Outcrops).......................86

4-11 Hydraulic Conductivities in Element Layer 5 (ILAZ Except Outcrops) ......................87

4-12 Hydraulic Conductivities in Element Layer 6 (CC2 Except Outcrops) ........................88 


\section{FIGURES (Continued)}

4-13 Hydraulic Conductivities in Element Layer 7 (mLAZ Except Outcrops) .................89

4-14 Hydraulic Conductivities in Element Layer 8 (CC1 Except Outcrops).....................90

4-15 Hydraulic Conductivities in Element Layer 9 (uLAZ Except Outcrops)....................91

4-16 Hydraulic Conductivities in Element Layer 10 (TCCZ Except Outcrops) ................92

4-17 Hydraulic Conductivities in Element Layer 11 (TCCZ Except Outcrops) .................93

4-18 Hydraulic Conductivities in Element Layer 12 (TZ Except Outcrops) .....................94

4-19 Hydraulic Conductivities in Element Layer 13 (TZ Except Outcrops) .....................95

4-20 Hydraulic Conductivities in Element Layer 14 (TZ Except Outcrops) .....................96

4-21 Hydraulic Conductivities in Element Layer 15 (AA Except Outcrops) .....................97

4-22 Hydraulic Conductivities in Element Layer 16 (AA Except Outcrops) ....................98

4-23 Hydraulic Conductivities in Element Layer 17 (AA Except Outcrops) ....................99

4-24 Hydraulic Conductivities in Element Layer 18 (A/UU Except Outcrops) ...............100

4-25 Hydraulic Conductivities in Element Layer 19 (A/UU Except Outcrops) ................101

4-26 Hydraulic Conductivities in Element Layer 20 (A/UU Except Outcrops) ...............102

4-27 Simulated Head in the Gordon Aquifer .......................................................... 103

4-28 Simulated Head in the Lower UTRA ................................................................ 104

4-29 Simulated Head in the Upper UTRA........................................................... 105

4-30 Simulated Head in the Aquifer Zone Containing the Water Table.......................... 106

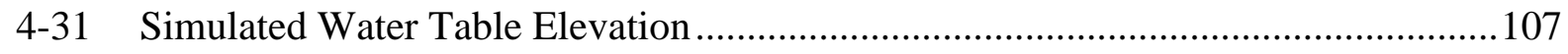

4-32 Simulated Flow Directions in the Gordon Aquifer............................................ 108

4-33 Simulated Flow Directions in the Lower UTRA ................................................. 109 


\section{FIGURES (Continued)}

4-34 Simulated Flow Directions in the Upper UTRA …........................................110

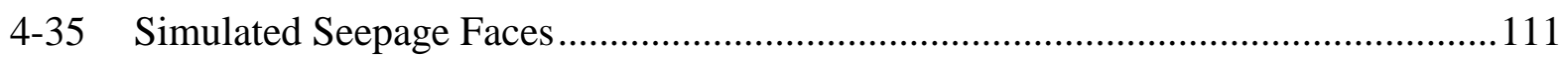

4-36 Simulated Rates of Recharge and Discharge ................................................... 112

4-37 Simulated Groundwater Flow Paths from the CRSB ..........................................113

4-38 Simulated Groundwater Flow Paths from the CBRP ...........................................114

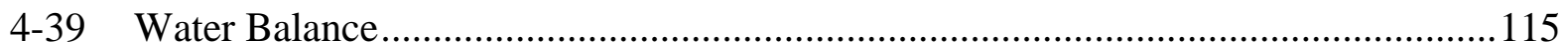

5-1 Plan View of CRSB/CBRP Model Domain and Finite-Element Mesh....................126

5-2 Perspective View of CRSB/CBRP Model Finite-Element Mesh ............................127

5-3 Simulated Groundwater Flow Paths from the CRSB and CBRP ...........................128

5-4 Tritium Releases to the C-Reactor Seepage Basins............................................ 129

5-5 Process Water Discharge to C-04 Outfall and C-Area Canal .................................. 130

5-6 Three-Dimensional Cutaway of Simulated CRSB Tritium Plume in January 1999

5-7 Plan and Cross-Sectional Views of Simulated CRSB Tritium Plume in

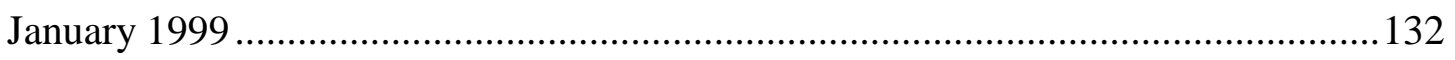

5-8 Maximum Concentration in Simulated CRSB Tritium Plume through Time ...........133

5-9 Vertical Average of Simulated CRSB Tritium Plume Above CC1 in January 1999

5-10 Simulated Historical Tritium Plumes Associated with CRSB ..............................135

5-11 Simulated Future Tritium Plumes Associated with CRSB ...................................136

5-12 Three-Dimensional Cutaway of Simulated CBRP TCE Plume in January 1999 ......137

5-13 Plan and Cross-Sectional Views of Simulated CBRP TCE Plume in January 1999 


\section{FIGURES (Continued)}

5-14 Maximum Concentration in Simulated CBRP TCE Plume through Time...............139

5-15 Vertical Average of Simulated CBRP TCE plume above CC1 in January 1999 ...... 140

5-16 Simulated Historical TCE Plumes Associated with CBRP ................................. 141

5-17 Simulated Future TCE Plumes Associated with CBRP …................................... 142 


\section{TABLES}

2-1 Summary of Hydraulic Head Targets ...................................................................... 59

2-2 Base Flow Estimates Based on a Single Field Measurement under Low-Flow

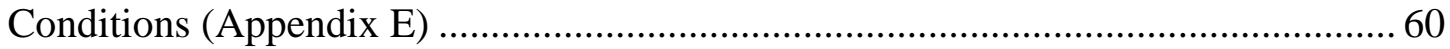

4-1 Calibration Summary for Groundwater Flow Targets........................................... 116

4-2 Calibration Summary for Hydraulic Head Targets............................................. 117

4-3 Calibration Summary for Hydraulic Conductivity ............................................. 118

5-1 Selected CPT Sampling Results for Tritium ......................................................... 143 
APPENDICES

APPENDIX A DATA COLLECTION AND HYDROGEOLOGIC MODEL METHODOLOGY

APPENDIX B HYDOSTRATIGRAPHIC DATA

APPENDIX C ANALYTICAL DATA

APPENDIX D DATA REFERENCES

APPENDIX E SUMMARY OF STREAM BASEFLOW AND WATER TABLE WORK CONDUCTED IN SUPPORT OF THE R-REACTOR AND K-REACTOR GROUNDWATER MODELING EFFORTS (SRT-EST-98-110)

APPENDIX F

HYDRAULIC HEAD TARGETS AND RESIDUALS

APPENDIX G METHODOLOGY FOR CORRELATING C-AREA CPT DATA TO HYDRAULIC CONDUCTIVITY AND UPSCALING TO THE MODEL GRID RESOLUTION

APPENDIX H C-AREA CPT LOGS WITH ESTIMATED PERCENT FINES AND HYDRAULIC CONDUCTIVITY 


\section{ACRONYMS}

\begin{tabular}{|c|c|}
\hline AS & air sparging \\
\hline $\mathrm{CC} 1$ & upper carbonate interval (of the "lower" aquifer zone) \\
\hline $\mathrm{CC} 2$ & lower carbonate interval (of the "lower" aquifer zone) \\
\hline $\mathrm{cfs}$ & cubic feet per second \\
\hline $\mathrm{Ci}$ & curie(s) \\
\hline CPT & cone penetrometer technology \\
\hline CPTu & cone penetrometer test \\
\hline CRBP & C-Area Burning/Rubble Pit \\
\hline CRESP & Consortium for Risk Evaluation with Stakeholder Participation \\
\hline CRSB & C Reactor Seepage Basins \\
\hline DOE & Department of Energy \\
\hline EMS & Environmental Monitoring Section \\
\hline EPD & Environmental Protection Department \\
\hline ERD & Environmental Restoration Department \\
\hline ES\&TD & Environmental Science and Technology Department \\
\hline FACT & Flow and Contaminant Transport (code) \\
\hline $\mathrm{ft}$ & feet \\
\hline GCU & Gordon confining unit \\
\hline GIMS & Geochemical Information Management System \\
\hline GSA & General Separations Area \\
\hline GWMA & Groundwater Model Area \\
\hline
\end{tabular}




\section{ACRONYMS}

\begin{tabular}{|c|c|}
\hline 1LAZ & lower interval of the "lower" aquifer zone \\
\hline $\mathrm{in} / \mathrm{yr}$ & inch(es) per year \\
\hline $\mathrm{kg}$ & kilogram \\
\hline LAZ & "lower" aquifer zone \\
\hline $\mathrm{MBCS}$ & Meyers Branch confining system \\
\hline MCL & minimum contamination level \\
\hline mLAZ & middle interval of the "lower" aquifer zone \\
\hline msl & mean sea level \\
\hline NAPL & non-aqueous phase liquid(s) \\
\hline PBF & Pen Branch Fault \\
\hline $\mathrm{pCi} / \mathrm{L}$ & picocurie(s) per liter \\
\hline $\mathrm{pCi} / \mathrm{ml}$ & picocurie(s) per milliliter \\
\hline $\mathrm{ppb}$ & part(s) per billion \\
\hline ShRINE & Savannah River Information Network Environment \\
\hline SRS & Savannah River Site \\
\hline SRTC & Savannah River Technology Center \\
\hline SVE & soil vapor extraction \\
\hline TCCZ & "tan clay" confining zone \\
\hline TCE & trichloroethylene \\
\hline $\mathrm{TZ}$ & transmissive zone of the "upper" aquifer zone \\
\hline UAZ & "upper" aquifer zone \\
\hline
\end{tabular}




\section{ACRONYMS}

uLAZ upper interval of the "upper" aquifer zone

USGS United States Geological Survey

UTR Upper Three Runs

UTRA Upper Three Runs aquifer

$\mathrm{V} \& \mathrm{~V} \quad$ verification and validation

WSRC Westinghouse Savannah River Company 
This page intentionally left blank 


\subsection{INTRODUCTION}

\subsection{Background}

The Savannah River Site (SRS) is a U.S. Department of Energy (DOE) facility that occupies 300 square miles within Aiken, Barnwell, and Allendale counties in southwestern South Carolina (Figure 1-1). The SRS was set aside in 1950 as a controlled area to produce nuclear materials for national defense. The DOE and its contractors are responsible for the operation of the SRS. Westinghouse Savannah River Company (WSRC) is currently contracted to manage and operate the site.

The SRS operated five reactors to produce special radioactive materials during the Cold War Period. R Reactor was the first production reactor to go on-line, achieving criticality in December 1953. P Reactor achieved criticality in February of 1954, followed by L Reactor in August 1954, K Reactor in October 1954, and C Reactor in March 1955. The reactors produced plutonium-238, plutonium-239, and tritium for uses related to national defense, and also generated special isotopes for non-defense research, medical uses, and space programs. These special isotopes included cobalt-60, polonium-210, uranium-233, curium-244, and californium-252.

The past disposal practices associated with SRS reactor operations created waste units within and adjacent to the five reactor areas. Reactor area waste units include seepage basins, Bingham pump outage pits, burning/rubble pits, rubble piles, acid/caustic basins, coal pile runoff basins, and coal ash basins. WSRC (1997) provides a detailed discussion of these waste units.

The reactor areas lie within five major drainage systems (basins). These include the Fourmile Branch, Pen Branch, Steel Creek, Lower Three Runs and Upper Three Runs basins (Figure 12). SRS facilities are normally situated on well-drained, topographically high areas (divides) which separate the basins. C Reactor lies on a relatively small topographic high that is within the Fourmile Branch basin (Figure 1-2). The C-Reactor Seepage Basins (904-66G, -67G, and $-68 \mathrm{G})$ and the C-Area Burning/Rubble Pit (131-C) are the two principal reactor waste units associated with C-Area.

The C-Reactor Seepage Basins (CRSBs) are located to the west of C Reactor (Figure 1-3). The waste unit consists of three unlined (earthen) basins constructed in 1957 to contain radioactive water discharged from the reactor process buildings. 
The seepage basins were used from 1959 to 1970 to dispose of low-level radioactive process purge water from the reactor disassembly basin. In 1963, the purge water was deionized and filtered and to remove solids and sludge prior to discharge to the basins. The seepage basins were not used from 1970 to 1978. During this period, purge water was mixed with large volumes of cooling water from the heat exchanger and discharged to area streams. Discharge to the CRSBs resumed in 1978 after improvements were made to the processing of purge water from the disassembly basin. The C-Reactor was shutdown for repairs in 1985, and the CRSBs have not received wastewater since 1987.

Waste disposal records indicate that the main basin received aqueous radioactive waste. Radionuclides in the wastewater from the disassembly basin, sumps, tanks and drums included tritium, chromium-51, cobalt-60, cesium-134, cesium-137, and other beta-gamma fission products (WSRC, 1993). Tritium releases to CRSBs the are documented in Environmental Protection Department (EPD) annual monitoring reports. Hetrick and Martin (1990) provide a summary listing through 1988, which covers the time span over which the CRSBs were active.

The C-Area Burning Rubble Pit (CBRP) is located approximately 2,500 feet northwest of C Reactor (Figure 1-3). The CBRP was a shallow, unlined excavation (approximately 25 feet wide and 350 feet long) with depths of approximately 8 to 12 feet and a volume of approximately 3,240 cubic yards. The CBRP was constructed in 1951 and used to dispose of and burn organic solvents, waste oils, paper, plastics, and rubber through 1973. After 1973, the pit was filled with inert rubble and soil (WSRC, 1994). Specific disposal amounts and periods of operation are unknown.

CPT sampling in 1999 detected high TCE concentrations in groundwater beneath and downgradient of CBRP (Appendix C). The history of solvent disposal at the pit and the persistence of high TCE concentrations 25 years after operations ceased suggests the presence of TCE in non-aqueous phase liquid (NAPL) within the vadose zone beneath the CBRP.

\subsection{Modeling Objective and Approach}

A groundwater flow model encompassing approximately $4 \mathrm{mi}^{2}$ within C Reactor area was developed to meet the planning objectives described in Section 4.2 of the General Groundwater Strategy for Reactor Area Projects (WSRC, 1997a). Specific objectives and goals of the $\mathrm{C}$ Reactor Area groundwater model are to: 
- Provide a common hydrogeologic and groundwater flow modeling framework for C Area that can be easily updated as additional field data is collected from waste site investigations.

- Provide a baseline groundwater flow model for use in subsequent flow and transport simulations for remedial/feasibility studies for C Area waste sites.

- Provide baseline transport simulations for CBRP and CRSB that reconstruct historical contaminant distributions and simulate future plume migration from each waste unit.

- Provide a working groundwater flow model for particle tracking and analysis to guide subsequent field characterization activities.

The model uses EarthVision ${ }^{\circledR}$ proprietary software to calculate two-dimensional grids, maps, and cross-sections of the hydrogeology. The groundwater modeling is performed using the Flow And Contaminant Transport (FACT) code. The FACT code is a finite-element code developed by the Savannah River Technology Center (SRTC) (Hamm and others, 1997, Aleman and Hamm, 1999).

\subsection{Description of the Study Area}

The SRS is centered 22.5 miles southeast of Augusta, Georgia, approximately 100 miles from the Atlantic Coast within the Upper Atlantic Coastal Plain Physiographic Province. The Savannah River forms the southwest boundary of the SRS (Figure 1-1). The SRS is situated on the Aiken Plateau of the Atlantic Coastal Plain at an approximate elevation of 300 feet above mean sea level (ft msl). Overall, the plateau has a highly dissected surface and is characterized by broad inter-fluvial areas with narrow, steep-sided valleys. Local relief can attain 280 feet (Siple, 1967). The Aiken plateau is generally well-drained, although many poorly drained sinks and depressions exist.

The model area, herein referred to as the C-Area Groundwater Model Area (GWMA) comprises approximately 4 square miles within the central SRS. The GWMA has low to moderate topographic relief and drains to the west via perennial and intermittent streams (Figure 1-3). The GWMA is bounded to the north and west by Fourmile Branch, to the south by Caster Creek, and to the west a line between Fourmile Branch and the headwaters of Caster Creek (Figure 1-3). 


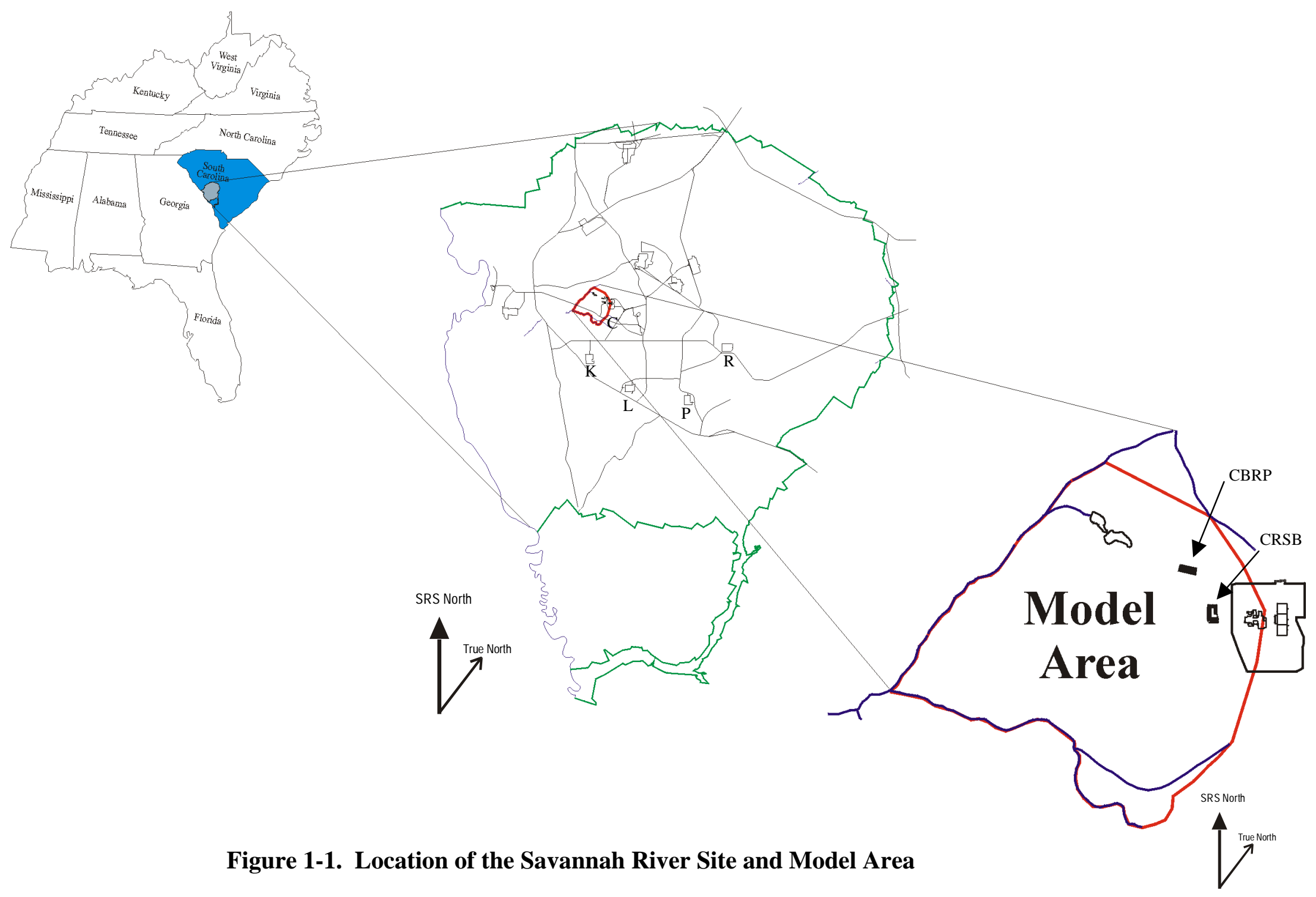




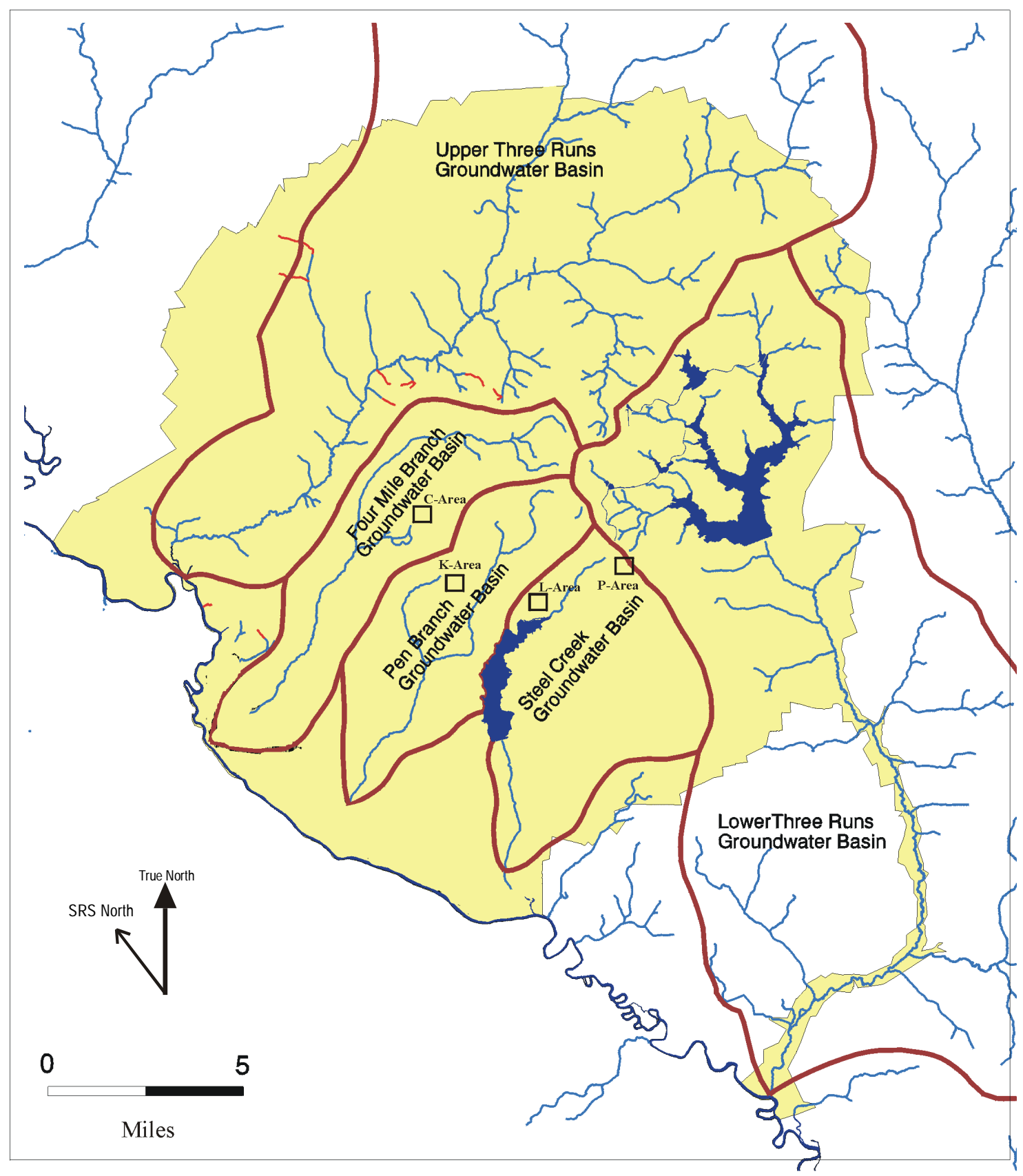

Figure 1-2. Location of Groundwater Basins at the Savannah River Site 


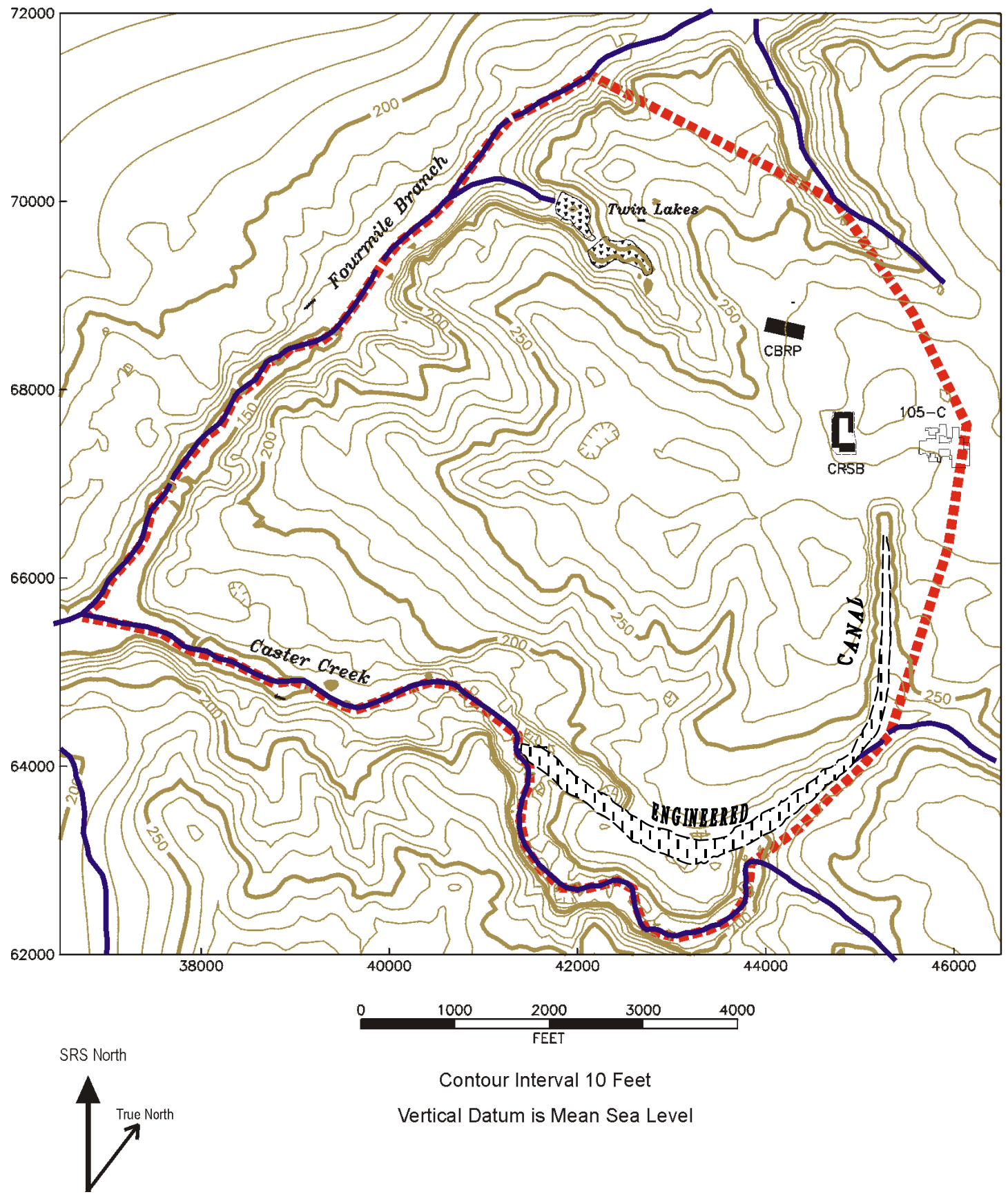

Figure 1-3. Location of Major Streams and Rivers in Model Area. Geologic Model Boundary Shown in Red 


\subsection{HYDROGEOLOGIC DATA AND CONCEPTUAL MODEL}

\subsection{SRS Geology}

The SRS lies within the Atlantic Coastal Plain, a southeast-dipping wedge of unconsolidated and semi-consolidated sediment that extends from its contact with the Piedmont Province at the Fall Line to the edge of the continental shelf. The sediment ranges from Late Cretaceous to Miocene in age and comprises layers of sand, muddy sand, and mud with minor amounts of calcareous sediment (Fallaw and Price, 1995). The Coastal Plain sediment rests unconformably on Triassic-aged sedimentary rock of the Dunbarton Basin and Paleozoicaged crystalline rock of the Appalachian orogen.

The Pen Branch Fault (PBF) offsets basement rock and Late Cretaceous to Tertiary-aged sediment beneath the areas south of the GWMA (Figure 1-1). Seismic studies and stratigraphic correlation indicate that the Pen Branch Fault is a sub-vertical growth fault with down-to-the-northwest movement sense. The PBF probably represents reactivation of a border fault in the basement rock along the north margin of the Dunbarton Basin (Snipes and others, 1993; Stieve and Stephenson, 1995). The areas south of the PBF are underlain by Triassic-aged sedimentary rock.

\subsection{SRS Hydrostratigraphic Units and Properties}

The hydrostratigraphy of the SRS has been the subject of several different classification schemes. This report incorporates the hydrostratigraphic nomenclature currently established for the SRS region by Aadland and others (1995), who present a thorough review and description of the units. Figure 2-1 correlates the hydrostratigraphic nomenclature with the local lithostratigraphy as defined by Fallaw and Price (1995). This report addresses the up-dip part of the Floridan aquifer system and the top of the Meyers Branch confining system as defined by Aadland and others (1995).

Flach and others (1999) presents a summary of permeability data from aquifer pumping tests, borehole permeability tests (slug tests), and laboratory tests of core samples from locations within the C, K, L, and P Area GWMA, which includes the C Area GWMA described in this report.

Appendix A presents a summary of the data collection and modeling methods that were utilized for this investigation. Appendix B presents locations of data points, hydrostratigraphic boundaries, and a summary of the two-dimensional grids calculated from 
the boundaries. Appendix $\mathrm{C}$ presents the analytical data collected for locations within the GWMA. Appendix D lists source documents for the data presented in Appendices B and C.

The project database includes results from analyses of groundwater samples taken from within the water table aquifer at CPT locations (Figure 2-2). The analytical data include results for tritium and TCE. The data presented in Appendix $\mathrm{C}$ indicate that TCE concentrations in groundwater beneath the GWMA range up to $130,000 \mu \mathrm{g} / \mathrm{L}$, and that the maximum tritium concentration was recorded at 57,800,000 $\mathrm{pCi} / \mathrm{L}$. Figures 2-3 and 2-4 present three-dimensional visualizations of the distribution of these analytical data. The sample intervals appear as cubes, which are color-coded to indicate the concentration, measured in the sample. Sample intervals colored yellow and red indicate measured concentrations above the MCL for the constituent ( $5 \mu \mathrm{g} / \mathrm{L}$ for TCE, 20,000 pCi/L for tritium). Figure 2-3 illustrates that most of the measured TCE contamination in the water table is located between CBRP and Fourmile Branch, indicating this waste unit as the likely source. Figure 2-4 suggests that CRSB is the likely source for the majority of the tritium activity within the water table as the largest measured levels lie between CRSB and the nearby drainages.

Geologic descriptions from three cores and CPT lithologic data from 81 locations are used to identify and delineate hydrostratigraphic boundaries within the near surface sediments beneath the study area. The boundaries were compiled into a hydrogeologic model using EarthVision geospatial analysis software. Figure 2-5 is a 3-dimensional visualization of the model and illustrates the stratigraphic relationships between the units. Figure 2-6 presents a map view of the surface outcrop of the units. The following sections describe the lithologic characteristics along with the configuration of the tops and thickness of the hydrostratigraphic units mapped for this study. It should be noted that the tops of the hydrostratigraphic units correspond closely with unconformities in the SRS region recognized by Fallaw and Price (1995). All of the maps exhibit contour patterns that reflect the variability in data density across the area. Directional references given in the following discussion are made with respect to the SRS grid system. 


\subsubsection{Meyers Branch Confining System}

The Meyers Branch confining system (MBCS) defines the base of the Floridan aquifer system beneath the study area. In the GWMA, the top of the MBCS is delineated by laterally continuous layers of dense, gray to black, clay and sandy clay of the Lang Syne Formation of the Black Mingo Group (Figure 2-1) (Aadland and others, 1991 and 1995). The MBCS exhibits a relatively gentle dip in a south-southeast direction.

\subsubsection{Floridan Aquifer System}

The Floridan aquifer system overlies the MBCS and includes the Gordon aquifer, Gordon confining unit, and Upper Three Runs aquifer within the GWMA (Figure 2-1). The Upper Three Runs aquifer is recharged primarily by precipitation (Hiergesell, 1998a). Groundwater flow maintains a significant vertical component from the Upper Three Runs aquifer down into the Gordon aquifer.

\subsubsection{Gordon Aquifer}

The Gordon aquifer constitutes the basal unit of the Floridan aquifer system beneath the GWMA and is the lowermost unit characterized in this report (Figure 2-1). Within the study area, the Gordon aquifer includes loose sand and clayey sand of the Congaree Formation and, where present, the sandy parts of the underlying Fourmile Branch and Snapp Formations (Figure 2-1), (Harris and others, 1990; Aadland and others, 1991 and 1995). The sand within the Gordon aquifer is yellowish to grayish orange and is sub- to well rounded, moderately to poorly sorted, and medium- to coarse-grained. Pebbly layers and zones of sand cemented with iron and silica are common. The Gordon aquifer includes rare interbeds of light tan to gray clay that range up to three feet in thickness. Lenses of clay less than 6 inches in thickness are common near the base of this unit. The Gordon aquifer contains a small amount of sporadically distributed calcareous sediment.

The configuration of the top of the Gordon aquifer is illustrated in Figure 2-7. The thickness of this unit is variable, ranging from approximately 60 feet to 160 feet across the SRS (Flach and others, 1999). Three multi-well pumping tests performed on wells in the GSA that are screened within the Gordon aquifer give permeability values that range from $1.86 \mathrm{E}-04$ to $4.50 \mathrm{E}+01 \mathrm{ft} / \mathrm{day}$ (Flach and others, 1999). Ten single-well pumping tests performed on wells from across the SRS that are screened within the Gordon aquifer give permeability values that range from 8.20E-01 to $1.43 \mathrm{E}+02 \mathrm{ft} /$ day (Flach and others, 1999). Aadland and others (1995) present additional information on pumping tests conducted within the Gordon aquifer. 


\subsubsection{Gordon Confining Unit}

The Gordon confining unit (GCU) separates the Gordon aquifer from the Upper Three Runs aquifer. This unit is commonly referred to as the "green clay" in previous SRS literature and includes sediment of the Warley Hill Formation (Figure 2-1). The unit comprises interbedded silty and clayey sand, sandy clay and clay. The clay is stiff to hard and is commonly fissile. Glauconite is a common constituent and imparts a distinctive greenish cast to the sediment, hence the informal name of "green clay" given to this unit. Zones of silicacemented sand and clay are present within the GCU in some cores taken from the GSA. Beneath the GWMA, the GCU includes some calcareous sediment and limestone, primarily calcarenaceous sand and clayey sand with subordinate calcarenaceous clay, micritic clay, and sandy micrite and limestone.

The GCU dips toward the south-southeast, increasing from approximately 10 feet to 80 feet in thickness (Figures 2-8 and 2-9). Laboratory tests of undisturbed samples taken from the GCU at locations across the SRS indicate vertical permeability ranges from $1.14 \mathrm{E}-06$ to 4.27E-01 ft/day and horizontal permeability ranges from 5.40E-06 to $1.22 \mathrm{E}-01 \mathrm{ft} /$ day within this unit (Flach and others, 1999).

\subsubsection{Upper Three Runs Aquifer}

The Upper Three Runs aquifer (UTRA), as defined in this report, includes all strata from the ground surface to the top of the GCU. The UTRA includes the informally named "upland" unit, Tobacco Road Sand, Dry Branch Formation, Clinchfield Formation, and Santee Limestone (Figure 2-1). For the purposes of hydrostratigraphic analysis, the UTRA is often locally divided into informal "lower" and "upper" aquifer zones that are separated by the "tan clay" confining zone (Figure 2-1). The informal zones are further differentiated into intervals where local hydrologic conditions and model resolution requirements warrant additional hydrogeologic detail.

“Lower" Aquifer Zone. The "lower" aquifer zone (LAZ) of the UTRA beneath the GWMA consists of dominantly fine-grained, well-sorted sand and clayey sand of the Santee Formation and parts of the Dry Branch Formation that are beneath the "tan clay" confining zone (Figure 2-1). The bulk of the carbonate sediment beneath the GWMA is contained within the Santee Limestone and lower part of the Dry Branch Formation and is included in the LAZ. Descriptions of drill core indicate that the carbonate sediment in this vicinity has a 
significant siliciclastic component, and consists primarily of calcarenaceous sand, micritic sand, shelly sand, with minor amounts of sandy calcarenite and shelly limestone.

For the purposes of this study, the LAZ is sub-divided into five informal hydrostratigraphic intervals. Characteristic log signatures of tip, sleeve, and pore pressure data from the CPT tool delineate these intervals. This sub-division was necessitated by the need to identify and map the layers of dense, relatively impermeable micritic sand and micritic sandy limestone that are present beneath this part of the SRS. In areas farther down-dip, sediment of similar lithology are considered to constitute significant aquitards (Aadland and others, 1995). From the bottom up, these intervals include the lower interval (ILAZ), carbonate interval 2 (CC2), middle interval (mLAZ), upper carbonate interval (CC1), and upper interval (uLAZ) of the LAZ.

Altitude-contour and isopach maps of the intervals within the LAZ are presented in Figures 2-10 and 2-19. The map in Figure 2-6 indicates that parts of the LAZ are exposed at the surface due to erosion and down-cutting along the stream valleys of Fourmile Branch and Caster Creek.

"Tan Clay" Confining Zone. The "tan clay" confining zone (TCCZ) of the UTRA is equivalent to the "tan clay" zone referred to in previous SRS reports. The includes sediment assigned to the Twiggs Clay and Irwinton Sand Members of the Dry Branch Formation (Figure 2-1). The zone contains light-yellowish tan to orange clay and sandy clay interbedded with clayey sand and sand. Clay layers are dispersed vertically and horizontally throughout the zone and are probably not laterally continuous over distances greater than 100 to 200 feet (Harris and others, 1990; Aadland and others, 1991). Beneath the GWMA, the TCCZ consists of two sequences of interbedded mud and sand with some calcareous sediment. The lower sequence contains light green to tan, slightly fissile clay and silty sand that is commonly interbedded with sand, silty sand, and coarse-grained, carbonate gravel. The carbonate gravel consists of oysters and other shell debris that is mixed with mud, sand, and gravel. The lower sequence commonly includes interbeds of relatively dense, well-indurated layers of a matrix-supported, shelly, sandy carbonate mudstone. This material consists of siliciclastic sand, mud, and gravel, shell debris, and other carbonate fragments contained in a matrix of mud-sized carbonate material (micrite).

The upper sequence within the TCCZ consists of interbedded siliciclastic sand and mud. The mud is waxy and commonly fissile, suggesting a very high clay content. The interbedded sand is generally well-sorted and medium-grained, with good interstitial porosity. The 
interbeds within this sequence vary from less than one to five feet in thickness. The individual layers of sand and mud cannot normally be correlated from core to core, but characteristic geophysical and CPT signatures can be readily identified at most data points, indicating that this interval is laterally continuous.

The configuration of the top of the TCCZ is illustrated in Figure 2-20 and an isopach map of the unit is presented in Figure 2-21. The configuration of the top of the TCCZ is very similar to that of the underlying LAZ. The measured thickness of the TCCZ ranges from approximately 10 feet to 20 feet. The TCCZ is deeply incised Fourmile Branch (Figures 2-6 and 2-20).

Laboratory tests of undisturbed samples taken from the TCCZ in cores across the SRS indicate vertical permeability ranges from $3.70 \mathrm{E}-08$ to $2.39 \mathrm{E}-01 \mathrm{ft} / \mathrm{day}$ and horizontal permeability ranges from $1.45 \mathrm{E}-05$ to $2.04 \mathrm{E}-01 \mathrm{ft} / \mathrm{day}$ within this unit (Flach and others, 1999).

"Upper" Aquifer Zone. The "upper" aquifer zone (UAZ) of the UTRA includes all strata from the ground surface to the top of the TCCZ. The UAZ includes the "upland" unit, Tobacco Road Sand, and part of the Dry Branch Formation (Figure 2-1). Massive beds of sand and clayey sand with minor interbeds of clay characterize the UAZ. The sediment within the "upland" unit is commonly very dense and clayey and often contains gravely sand.

The top of the UAZ is defined by the present-day topographic surface. The UAZ may be subdivided into four informal hydrostratigraphic intervals that are delineated by characteristic log signatures of tip, sleeve, and pore pressure data from the CPT tool. From the bottom up, these intervals include the "transmissive zone", "AA" interval, "A" interval, and an undifferentiated soils interval ("uu" interval) (Figure 2-1). Altitude-contour and isopach maps of these intervals are presented as Figures 2-22 through 2-23. Each interval bears distinctive CPT log signatures, which are indicative of their overall hydrogeology. These informal units were initially identified at R-Area (WSRC,1997b), and have been primarily identified on a local basis. Flach and others (1999) presents a correlation of these intervals between different areas of the SRS.

The "transmissive zone" (TZ) corresponds with the interval of relatively clean sand that makes up the upper parts of the Dry Branch Formation (Figure 2-1). Logs of CPT data from this interval typically show very high tip and sleeve values with relatively low tip/sleeve ratios (Figure 2-29). The tip/sleeve ratios from the TZ normally produce very smooth 
patterns on CPT logs. This is probably indicative of the relatively massive sand layers that constitute this unit. The base of the TZ is commonly found at elevations between 170 and $190 \mathrm{ft}$ msl and is picked where the relatively high friction ratio values of the TCCZ drop to values that are generally less than 2.0, and the tip and sleeve values both demonstrate abrupt increases which are sustained with decreasing depth (Figure 2-29).

Figure 2-22 presents an altitude contour map for the top of this unit. The map indicates that the $\mathrm{TZ}$ follows the regional dip toward the south-southeast. Local high and low areas on this surface generally correlate with highs and lows on the top of the TCCZ (Figure 2-20) The isopach map for the TZ is shown in Figure 2-23. The thickness of the TZ varies locally, but generally increases in a southeast direction. Figure 2-6 shows that this unit is exposed on the slopes above the stream valleys within the GWMA.

The base of the "AA" interval is delineated from CPT logs where relatively small and constant friction ratio values in the TZ increase abruptly, and the tip and sleeve values both show a significant decrease. The base of the "AA" interval is commonly found at elevations between 220 and 200 (ft msl). Within the "AA" interval, logs of tip and sleeve readings indicate relatively low and generally consistent values that are accompanied by an erratic pattern of highly variable friction ratio readings (Figure 2-29). Logs of tip and sleeve readings from the "AA" interval generally have a "blocky" appearance when compared with tip and sleeve data from the TZ (Figure 2-29). The generally blocky pattern of the tip and sleeve curves and the highly variable and erratic friction ratio curve indicate the "AA" interval consists of a sequence of interbedded sand, and silty sand, probably of much lower transmissivity than the underlying TZ. The sediment contained within the "AA" interval is generally correlative with the lower parts of the Tobacco Road Sand (Figure 2-1). A comparison of CPT logs with geologic and geophysical data from the same location indicates that the base of the "AA" interval corresponds with the base of the Tobacco Road Sand. Figures 2-24 and 2-25 present altitude-contour and isopach maps of this unit

The "A" interval is correlative with the upper parts of the Tobacco Road Sand. The base of the "A" interval is delineated on CPT logs where the friction ratio curve changes abruptly from the highly variable values and erratic pattern of the "AA" interval to much smaller values with a "stable" curve pattern (Figure 2-29). The tip and sleeve values near the base of the "A" interval are often relatively large, and commonly show a gradual decrease up-section with a corresponding gradual increase in friction ratio values. These log-pattern changes correlate with the fining-upward sequence that is commonly observed in continuous core samples taken from the upper part of the Tobacco Road Sand. Figure 2-29 illustrates this 
relationship between the CPT log patterns and the lithology changes within this unit. Figures 2-26 and 2-27 present altitude-contour and isopach maps for this interval.

The uppermost UAZ consists of the fluvial sediments of the "upland" unit, recent alluvial material deposited by active stream reaches (outside of the Savannah River) and any local soil horizons which have formed in-situ from any of the lithostratigraphic units. For the purposes of this study, all of these have been grouped into a single "undifferentiated upper soils" ("uu") interval. Figure 2-1 illustrates the relative position of the "uu" interval with respect to the underlying units.

The "uu" interval can usually be identified on CPT logs where the sleeve stress values show a significant increase (up-section). This change accompanied by a drastic and abrupt increase in the friction ratio commonly to sustained values in excess of five (Figure 2-29). Friction ratio values within the "uu" interval generally exhibit an irregular pattern of drastic changes that often define groups, giving the curve a rough, "blocky" pattern (Figure 2-29). The top of the "uu" interval commonly contains material that displays very low tip and sleeve values. These readings represent material that is interpreted to be the near-surface soil horizon. Because the "uu" interval includes the sediments assigned to the "upland" unit and surficial soil horizons, it typically appears as a "draping" over the top of the other units, when viewed in three dimensions or in cross-section (Figure 2-5). This is also suggested by the isopach contour patterns for this unit (Figure 2-28).

\subsection{Hydrogeology}

\subsubsection{Water Table}

The water table aquifer is contained within the UTRA and includes all saturated material from the water table to the top of the GCU. The water table aquifer is commonly divided into the informal UAZ and LAZ, separated by the TCCZ. For this report, no distinction is made for the upper and lower zones because the majority of well data is from the upper zone as there are very few wells screened in the lower part of the water table aquifer within the model area at this time. A water table map of the reactor areas model domain is shown in Figure 2-30. The map is based on water level measurements obtained from selected wells along with careful examination of flowing reaches of the headwater segments of the streams (Hiergesell, 1998a). The configuration of the water table is tightly controlled by the local topography and drainage system. Wells are scarce in the reactors area with the majority of the wells located around the reactor facilities. In addition to the regional water table map, 
Figure 2-31 illustrates the water table configuration in more detail in C-Area. For further discussion of the water table in the reactor areas, the reader is referred to Hiergesell (1998a).

\subsubsection{Gordon Aquifer Potentiometric Surface}

The Gordon aquifer is the lowermost aquifer of interest in this study and represents the basal unit of the Floridan aquifer system in C-Area (Figure 2-1). Figure 2-32 illustrates the Gordon aquifer potentiometric surface (Hiergesell, 1999). Data is limited for the Gordon aquifer in C-Area. The Gordon aquifer discharges to the Upper Three Runs valley to the northnorthwest and to the Savannah River valley to the west-southwest.

\subsubsection{Hydraulic Head Targets}

In addition to constructing potentiometric maps for conceptual understanding of groundwater flow and boundary condition specification (e.g. Figures 2-31 and 2-32), hydraulic head data are valuable model calibration targets. Because steady-state groundwater flow is the focus of this effort, long-term, time-averaged head data are of most interest as model calibration targets. The primary source of uncertainty in mean water level is transient fluctuation in individual readings that are on the order of a few feet. Surveying errors, measurement errors, etc. are generally very small in comparison.

Water level data for most wells at the SRS are available from the Geochemical Information Management System (GIMS), which can be accessed through the Savannah River Information Network Environment (ShRINE). The data are also published in periodic well inventory and monitoring reports; see Environmental Protection Department and Exploration Resources, Inc. (1996a, b) for example. GIMS archives data obtained through a groundwater monitoring program administered by the Environmental Monitoring Section (EMS) of the Environmental Protection Department (EPD). The GIMS database is known to contain erroneous entries. Outliers were identified as single readings that deviated from the average value by more than $20 \mathrm{ft}$ and eliminated. With the remaining data, the sample standard deviation of the mean value was computed as (Walpole and Myers, 1978, section 5.5)

$$
\mathrm{s}_{\mathrm{m}}=\frac{\mathrm{s}}{\sqrt{\mathrm{n}}}=\frac{1}{\sqrt{\mathrm{n}}} \times\left[\frac{1}{\mathrm{n}-1} \sum_{\mathrm{i}=1}^{\mathrm{n}}\left(\mathrm{h}_{\mathrm{i}}-\overline{\mathrm{h}}\right)^{2}\right]^{1 / 2}
$$

Mean values with an uncertainty exceeding $3 \mathrm{ft}$ at $95 \%$ confidence $\left(2 \mathrm{~s}_{\mathrm{m}}>3 \mathrm{ft}\right)$ were eliminated, with the idea that uncertainty in a hydraulic head target should not exceed the 
calibration goal. Previous models covering relatively small areas of the SRS have generally achieved a root-mean-square residual of $3 \mathrm{ft}$ (e.g. Camp Dresser \& McKee, 1989; GeoTrans, 1992; Flach and Harris, 1997). Sample standard deviations could not be computed for wells with a single reading, and the single reading was accepted the target for steady-state flow calibration.

Valuable data from wells not included in the EMS monitoring program are also available. The Environmental Science and Technology Department (ES\&TD) has monitored the P-series wells and other SRS wells for several years (Hiergesell, 1998). Water level data are also available from Environmental Restoration Department (ERD) documents, such as the RFI/RI/BRA for the CMP Pits (WSRC, 1996). In 1998, piezometer clusters were installed at 17 locations across the reactors area for the purpose of defining water levels in remote areas (Figure 2-33) (WSRC, 1999). The two-piezometer clusters targeted the "upper" and "lower" UTRA. These data supplement the head targets derived from the GIMS database.

Flach and others (1999, Appendix F) provide a listing of targets and summary statistics for the $\mathrm{C}, \mathrm{K}, \mathrm{L}$ and $\mathrm{P}$ areas, based on the methodology described above. Appendix F contains a subset of these hydraulic head targets that lie within the active C-Area model domain. Each well was assigned to the appropriate hydrostratigraphic unit, as defined by the picks and grids presented in Section 2.2. The results are summarized in Table 2-1. Wells assigned to the Gordon aquifer are screened completely within the Gordon aquifer. Wells and piezometers above the Gordon confining unit are assigned to an aquifer zone if at least half the screen lies within that zone. Otherwise, the water level is ignored as model calibration target. There are a total of 48 targets within the active model domain.

\subsection{Groundwater Recharge and Discharge}

Groundwater flow in upper aquifers at the Savannah River Site is driven by recharge, with streams intercepting flow from areas of higher groundwater elevations (Figures 2-30 and 232). Nearly all recharge within the CKLP model area discharges to streams within or bounding the same area, usually the nearest stream. For this type of groundwater flow system, recharge and discharge estimates, coupled with head measurements and confining unit leakance estimates, define the overall horizontal conductivity values of upper aquifers required to calibrate a numerical flow model. Because conductivity data at the model scale are typically non-existent, groundwater flow estimates are important model calibration targets. 
At least three independent investigations of surface groundwater recharge have been performed in or near the SRS. Parizek and Root (1986) conducted a detailed hydrologic budget study of the McQueen Branch basin. They estimated average recharge for the basin at 15.6 in/yr. Parizek and Root (1986) computed this value by dividing the total volumetric rate of recharge by the total basin area. The average recharge rate excluding seepage/wetland areas would therefore be somewhat larger. Hubbard $(1984,1986)$ conducted a multi-year lysimeter study at the SRS burial grounds in the General Separations Area and measured an average recharge of about $16 \mathrm{in} / \mathrm{yr}$ for grass cover. Based on lysimeters with small pine trees growing within them, Hubbard (1986) estimated recharge to be $6 \mathrm{in} / \mathrm{yr}$ for forested areas. Hubbard (1986) also reported that Denehy and McMahon (1985) measured 15 in/yr of recharge at the Chem-Nuclear site in Barnwell, South Carolina. Parizek and Root (1986) and Looney and others (1987) report that Cahill (1982) estimated recharge to be about $15 \mathrm{in} / \mathrm{yr}$ at the Low Level Radioactive Solid Waste Burial Site near Barnwell, South Carolina (ChemNuclear). It is unclear from the literature cited here whether the Denehy and McMahon (1985), and Cahill (1982) studies are related, apart from being conducted at the same location.

From these studies, the average recharge over the Savannah River Site is estimated to be about $15 \mathrm{in} / \mathrm{yr}$. The average rate excluding groundwater discharge areas would be somewhat higher. This estimate may be high due to a bias toward analysis of developed areas that tend to be less forested and flatter. The data for forested conditions are difficult to reconcile. Hubbard (1985) estimated recharge at $6 \mathrm{in} / \mathrm{yr}$ for forested areas. On the other hand, the vegetation of McQueen Branch basin studied by Parizek and Root (1986) study was 85\% evergreen and deciduous forest, and produced an estimate of nearly $16 \mathrm{in} / \mathrm{yr}$. The average of these two estimates is $10 \mathrm{in} / \mathrm{yr}$. Considering that the area of interest in this study is relatively undeveloped and heavily forested, perhaps a reasonable range to consider for groundwater flow modeling sensitivity studies is 10 to $16 \mathrm{in} / \mathrm{yr}$.

Hiergesell (1998b, 1998c) measured base flow for small streams in C-Area and the data are presented in Appendix E. Selected measurements pertinent to C-Area are summarized in Table 2-2. Hiergesell $(1998 b, 1998 c)$ also estimated the point of effluence along small streams and refined an ARC/INFO USGS coverage of live stream reaches, as illustrated by Figure 2-34. The uncertainty in these base flows has not been estimated. 


\subsection{Conceptual Model of Groundwater Flow and Solute Transport}

Based on the hydrogeology and groundwater recharge and discharge discussed in the previous sections, a conceptual model for subsequent groundwater flow and solute transport was developed. Figure 2-35 presents a schematic depiction of the hydrogeologic conceptual model (HCM) for groundwater flow within the study area. Groundwater flow in the Upper Three Runs aquifer is seen to be driven by recharge, with Fourmile Branch and tributaries intercepting flow from higher elevations (Figures 2-30 and 2-31). The underlying Gordon aquifer is influenced at a regional scale by the Savannah River and Upper Three Runs, which appear to completely drain the aquifer and function as no-flow lines (Figure 2-32). Within CArea, the Gordon aquifer is recharged by the overlying Upper Three Runs aquifer. Except for process water outfalls, surface water bodies gain from groundwater discharge. Aadland and others (1995, Plate 17) report the leakance of the Crouch Branch confining unit (of the Meyers Branch confining system) as roughly $3 \times 10^{-6}$ day $^{-1}$, which corresponds to $0.13 \mathrm{in} / \mathrm{yr}$ for every $10 \mathrm{ft}$ of head difference. The head difference across the Crouch Branch confining unit is near zero across C-Area (Aadland and others, 1995, Figure 30). Flow across the unit is therefore a small fraction of total recharge, and could probably be neglected. A representative leakance coefficient for the Gordon confining unit in the study area appears to be roughly $10^{-5}$ day $^{-1}$ (Aadland and others, 1995, Plate 13). The head difference across the Gordon confining unit is highly variable due to large variation in the water table. Using a head difference of $50 \mathrm{ft}$ for example, the Darcy velocity through the unit would be $2.2 \mathrm{in} / \mathrm{yr}$ or $15 \%$ of surface recharge. Therefore, groundwater flow in the Gordon aquifer appears to be influenced significantly by recharge from the overlying UTR aquifer, and lateral flow across the model boundaries. The Site Utilities Department well database on ShRINE indicates that no producing wells are screened in the Gordon aquifer in C-Area.

Solute groundwater contamination originating in the C-Area is expected to be confined to the Upper Three Runs and Gordon aquifers. Most surface recharge discharges to the nearest stream (e.g. Fourmile Branch), with the balance entering the Gordon aquifer. In C-Area, the flow between the Crouch Branch and Gordon aquifers is slightly upward on average, so contamination is not expected to enter the Crouch Branch aquifer.

Based on the above concept of groundwater flow and contaminant migration in C-Area, a three-dimensional numerical model will be required to represent the complex multidimensional flow patterns that drive contaminant migration. As shown in Figure 2-35, the minimum extent of the numerical model should include the CBRP, CRSB and downgradient areas to Fourmile Branch and Caster Creek. Because contamination essentially originates at 
the ground surface, the numerical model should ideally extend from ground surface to the bottom of the Gordon aquifer. A larger lateral domain may be desirable to take advantage of natural streams and drainages. These features can be assigned a drain boundary condition, which is usually more certain than an alternative prescribed head boundary condition. The numerical representation should have at least one layer for each hydrostratigraphic interval depicted in Figure 2-35. Additional layers are desirable to resolve the vertical flow field for more accurate three-dimensional particle tracking, and simulate contaminant plumes which are typically 5 to $20 \mathrm{ft}$ thick. The actual conductivity field is known to be highly variable and this heterogeneity strongly affects contaminant migration. Additional model layers within units are also desirable for representing heterogeneity where CPT data are available. The numerical model should capture as much heterogeneity as feasible given the available characterization data.

\subsection{Hydrologic Properties}

In addition to the unit-specific hydraulic conductivity data discussed above, soil characteristic curves, effective porosity, and specific storage data are needed for model development. The steady-state hydraulic head and Darcy velocity fields in the saturated zone are affected only by horizontal and vertical hydraulic conductivity, making these remaining properties less critical to model development. Soil characteristic curves (capillary suction and relative permeability as a function of water saturation) affect the flow solution in unsaturated regions. Effective porosity affects groundwater "particle" tracing results, which rely on the pore velocity field. Specific storage affects transient flow only, and then only in confined aquifer systems for practical purposes. Characterization data available for defining these hydraulic properties in the model are identified below. Given the general scarcity and uncertainty in the data, generic estimates to be applied model-wide are appropriate.

\subsubsection{Soil Characteristic Curves}

Relative permeability and capillary suction head as a function of water saturation are referred to as soil characteristic curves. These relationships are difficult to measure accurately, and testing is expensive. Very little data are available for SRS unconsolidated sediments. O'Brien \& Gere (1991) obtained a small set of water retention (capillary suction versus saturation) data for M-Area sediment samples. The data have been plotted by Flach and others (1996, Figures 11 and 12). Yu and others (1993) obtained both relative permeability and water retention data for remolded GSA sediments to be used for Environmental Restoration construction projects. Recently, Amidon (1996) obtained water retention data 
from 3 undisturbed soil samples collected from the vadose zone around the Burial Grounds Complex. According to Looney and others (1987), Gruber (1981, 1983) and Parizek and Root (1986) measured soil water content in the vadose zone and suggested the average water content is approximately $30 \%$ (water volume/total volume). Given the scarcity of the data and lacking a specific need for detailed vadose zone modeling, a simplified approach for defining soil characteristic curves is taken as shown in Figure 2-36. The curves are chosen to align with data for sandy sediments as opposed to clayey sediments (see Flach and others (1996), Figures 11 and 12). The relative permeability at residual saturation is set to 0.1 instead of zero to avoid slow convergence. These "pseudo-soil" characteristic curves are adequate for transporting water and contaminants through the vadose zone to the water table, provided detailed, accurate information about the unsaturated zone is not needed. The most important aspect of these curves is the assumed residual saturation value (40\%), which has the strongest effect on average vadose zone saturation. Groundwater travel times through the vadose zone are affected by saturation through pore velocity.

\subsubsection{Effective (Kinematic) Porosity}

Aadland and others (1995, p. 44) analyzed laboratory data from 83 selected sediment samples taken from various low permeability beds within the Upper Three Runs aquifer. For 28 "clayey to very clayey, often silty, sand" samples the total porosity averaged $40 \%$. For 55 "sandy, often silty clay, and clay" samples, the average total porosity is $41 \%$. Aadland and others (1995, Table 3) also calculated the total porosity of the sandy portions of the Upper Three Runs aquifer using the Beard and Weyl (1973) method, and arrived at an average total porosity of 35\%. For the Gordon aquifer, the result is 34\% (Aadland and others, 1995, Table 7). More recently, Smits and others (1997) compiled a database of porosity measurements for the General Separations Area. The arithmetic average of these values, mostly from low permeability samples, is $45 \%$. From these data and analyses, total porosity in aquifer zones appears to average about $40 \%$.

An "effective" porosity value, smaller than the total porosity, is commonly used for transport simulations and particle tracing related to contaminant migration. As discussed by De Marsily (1986, Chapter 2), two types of porosity are commonly and unfortunately referred to as "effective porosity". The first is specific yield or drainage porosity of an unsaturated soil, $\omega_{\mathrm{d}}$, and the second is kinematic porosity of a saturated medium, $\omega_{\mathrm{c}}$. Section 2.3 .3 of De Marsily (1986) summarizes which porosity (total included) to use for which application. For saturated-zone particle tracing and transport simulations, the kinematic porosity is appropriate and the focus of effective porosity discussions in this report. 
An effective porosity can be used to account for regions of relatively immobile water, ranging from grain-sized "dead-end" pores to macro-scale clay intervals, which do not effectively participate in contaminant transport. The presence of immobile water does not necessarily dictate the use of an effective porosity (De Marsily, 1986, p. 259). If the solute contaminant perfectly penetrates the immobile water $\left(K^{\prime}=1, C^{\prime}=C\right.$ in De Marsily (1986)) (or there is no immobile water), then total porosity is appropriate $(\omega)$. On the other hand, if a model block contains sub-regions of immobile water that a solute will not penetrate $\left(K^{\prime}=0, C^{\prime}=0\right)$, then a lower, "effective" porosity is appropriate (kinematic, $\omega_{\mathrm{c}}$ ).

Effective porosity can be estimated by assuming that only the largest scale regions of relatively immobile water are not effectively penetrated by contaminant. At smaller scales, contaminant is able to effectively diffuse into regions of immobile water. Macro-scale regions of immobile water can reasonably be defined as sediment intervals with more than $25 \%$ mud. For the General Separations Area, 32\% of the nearly 40,000 ft of sediment core contains greater than $25 \%$ mud, based on analysis of the lithologic data compiled by Smits and others (1997). This suggests that as low as $68 \%$ of a typical aquifer is effectively available for contaminant transport, and that effective porosity is approximately $25 \%$ (68\% of $40 \%$ total porosity). This estimate may be a conservative (low) estimate for effective conductivity, because in reality some contamination would penetrate the lower conductivity intervals. This value is consistent with the recommendations of Looney and others (1987, p. 39 ), who recommend assuming an effective porosity of 0.2 for risk calculations. Transport sensitivity studies should consider an effective porosity range of approximately $20 \%$ to $40 \%$.

\subsubsection{Specific Storage}

Specific storage is relevant only to transient flow simulations, and therefore has no effect on the steady-state results presented in later sections. Specific storage is defined by (Freeze and Cherry, 1979, p. 59)

$$
S_{s}=\rho g(\alpha+\eta \beta)
$$

where

$\mathrm{S}_{\mathrm{S}} \quad$ specific storage

$\rho \quad$ density of water $\left(\sim 1000 \mathrm{~kg} / \mathrm{m}^{3}\right)$

g gravitational acceleration $\left(9.8 \mathrm{~m} / \mathrm{s}^{2}\right)$ 
$\alpha \quad$ compressibility of porous medium

$\eta \quad$ total porosity

$\beta$ compressibility of water $\left(4.4 \times 10^{-10} \mathrm{~m}^{2} / \mathrm{N}\right)$

Compressibility ranges from $10^{-6}$ to $10^{-8} \mathrm{~m}^{2} / \mathrm{N}$ for clay and from $10^{-7}$ to $10^{-9} \mathrm{~m}^{2} / \mathrm{N}$ for sand (Freeze and Cherry, 1979, Table 2.5). Assuming a nominal compressibility value of $5 \times 10^{-8} \mathrm{~m}^{2} / \mathrm{N}$ and a total porosity of $40 \%$ yields $1.5 \times 10^{-4} \mathrm{ft}^{-1}$ for specific storage. 


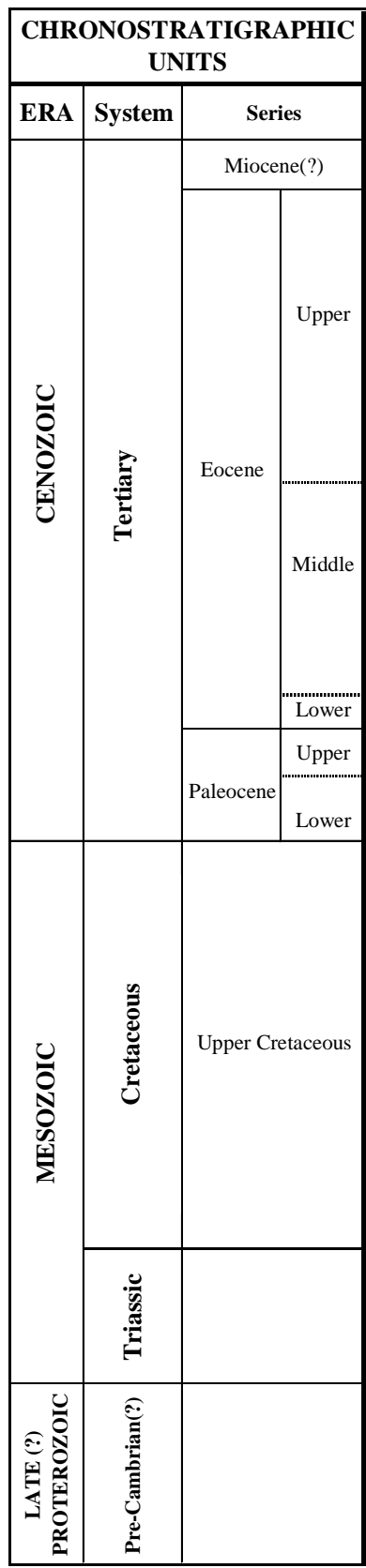

\begin{tabular}{|c|c|c|}
\hline \multicolumn{3}{|c|}{$\begin{array}{c}\text { LITHOSTRATIGRAPHIC UNITS } \\
\text { (Modified from Fallaw and Price, 1995) }\end{array}$} \\
\hline Group & \multicolumn{2}{|c|}{ Formation } \\
\hline & \multicolumn{2}{|c|}{ "upland" unit } \\
\hline \multirow{5}{*}{$\begin{array}{c}\text { Barnwell } \\
\text { Group }\end{array}$} & \multicolumn{2}{|c|}{ Tobacco Road Sand } \\
\hline & \multirow{3}{*}{$\begin{array}{l}\text { Dry Branch } \\
\text { Formation }\end{array}$} & Twiggs Clay Mbr. \\
\hline & & Griffins Landing Mbr. \\
\hline & & Irwinton Sand Mbr. \\
\hline & \multicolumn{2}{|c|}{$\begin{array}{l}\text { Clinchfield } \\
\text { Formation }\end{array}$} \\
\hline \multirow{4}{*}{$\begin{array}{l}\text { Orangeburg } \\
\text { Group }\end{array}$} & \multirow{2}{*}{\multicolumn{2}{|c|}{$\begin{array}{c}\text { Santee } \\
\text { Formation }\end{array}$}} \\
\hline & & \\
\hline & \multicolumn{2}{|c|}{ Warley Hill Formation } \\
\hline & \multicolumn{2}{|c|}{ Congaree Formation } \\
\hline \multirow{5}{*}{$\begin{array}{c}\text { Black } \\
\text { Mingo } \\
\text { Group } \\
\end{array}$} & \multicolumn{2}{|c|}{ Fourmile Branch Formation } \\
\hline & \multicolumn{2}{|c|}{ Snapp Formation } \\
\hline & \multicolumn{2}{|c|}{ Lang Syne Formation } \\
\hline & \multicolumn{2}{|c|}{ Sawdust Landing Formation } \\
\hline & \multicolumn{2}{|c|}{ Steel Creek Formation } \\
\hline \multicolumn{3}{|l|}{ Black Creek } \\
\hline & \multicolumn{2}{|c|}{ Middendorf Formation } \\
\hline & \multicolumn{2}{|c|}{ Cape Fear Formation } \\
\hline $\begin{array}{c}\text { Newark } \\
\text { Supergroup }\end{array}$ & \multicolumn{2}{|c|}{ Sedimentary Rock (Dunbarton Basin) } \\
\hline & \multicolumn{2}{|c|}{ Crystalline Basement Rock } \\
\hline
\end{tabular}

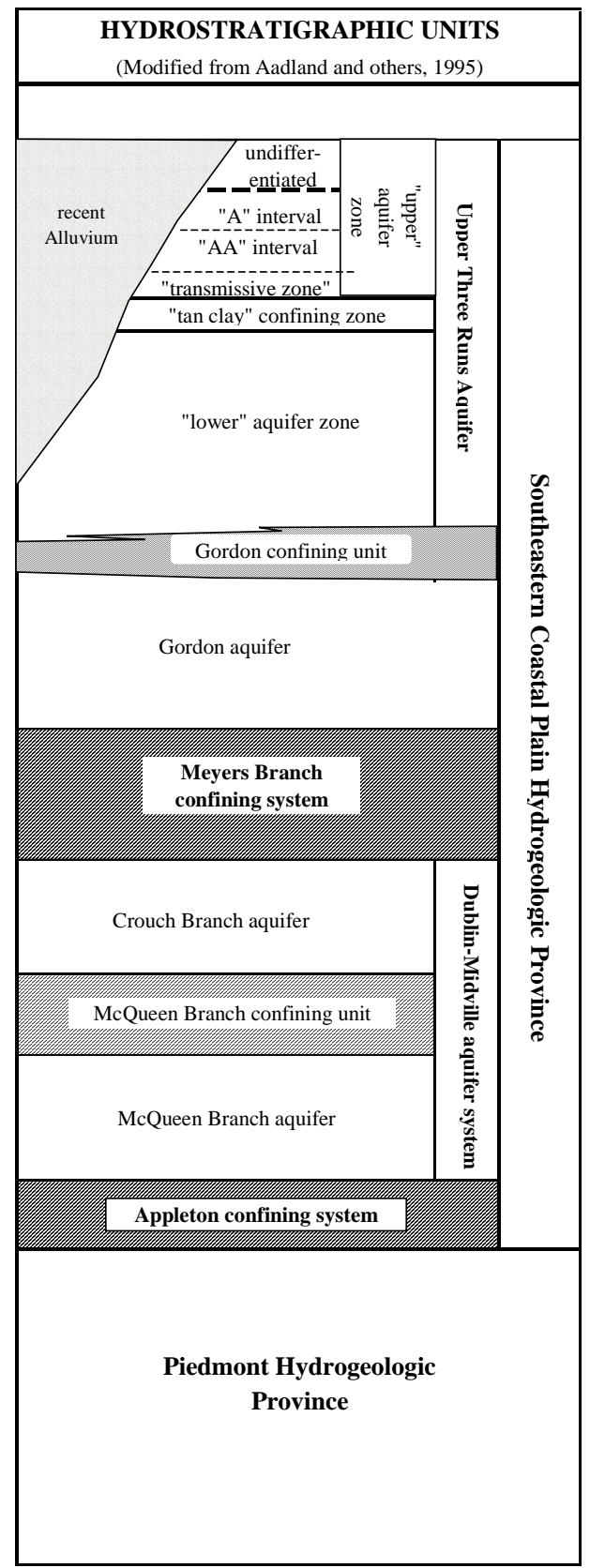

Figure 2-1. Comparison of Lithostratigraphic and Hydrostratigraphic Units at SRS 


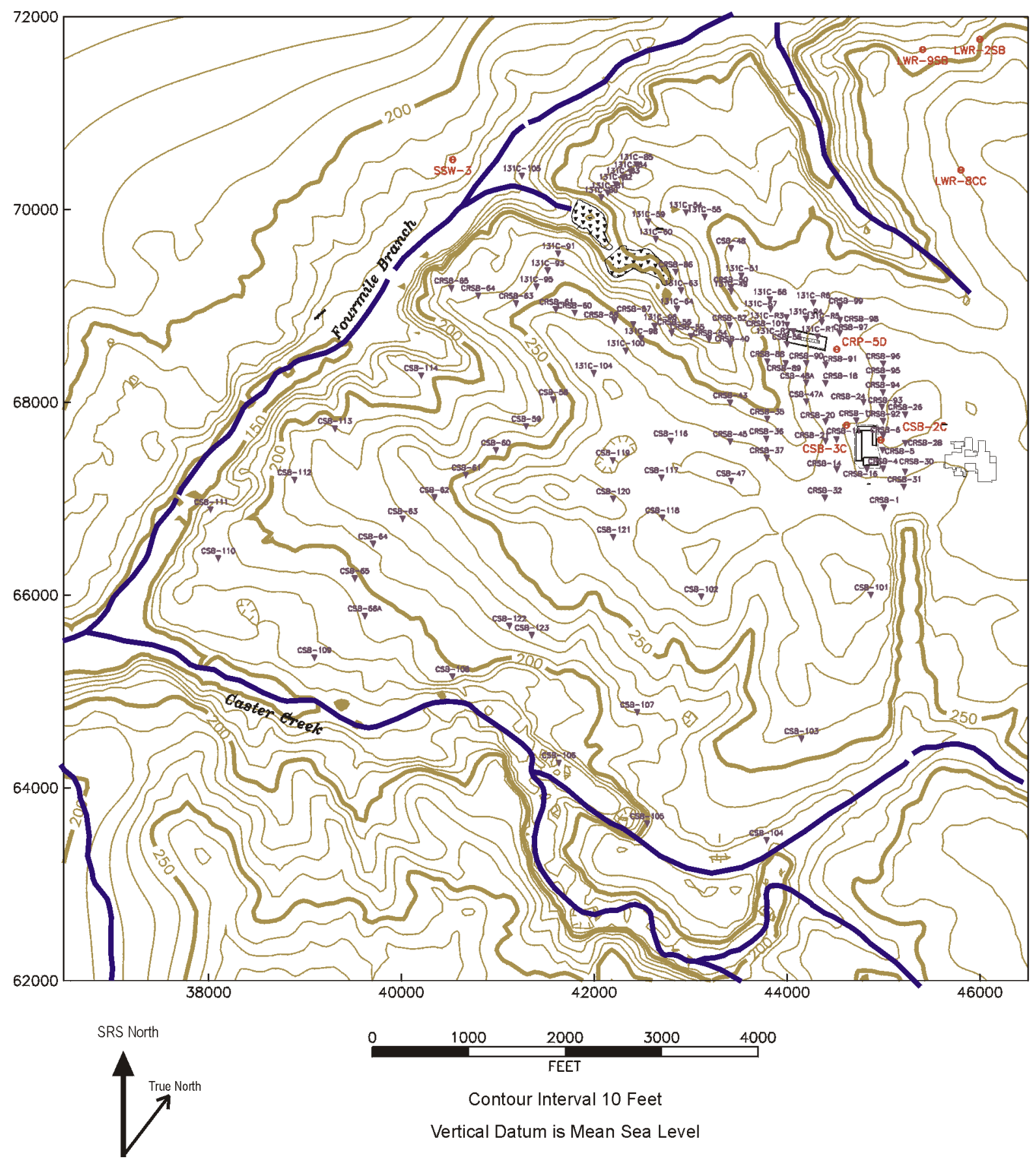

Figure 2-2. Locations of Cone Penetrometer Tests and Geologic Cores 
TCE Results

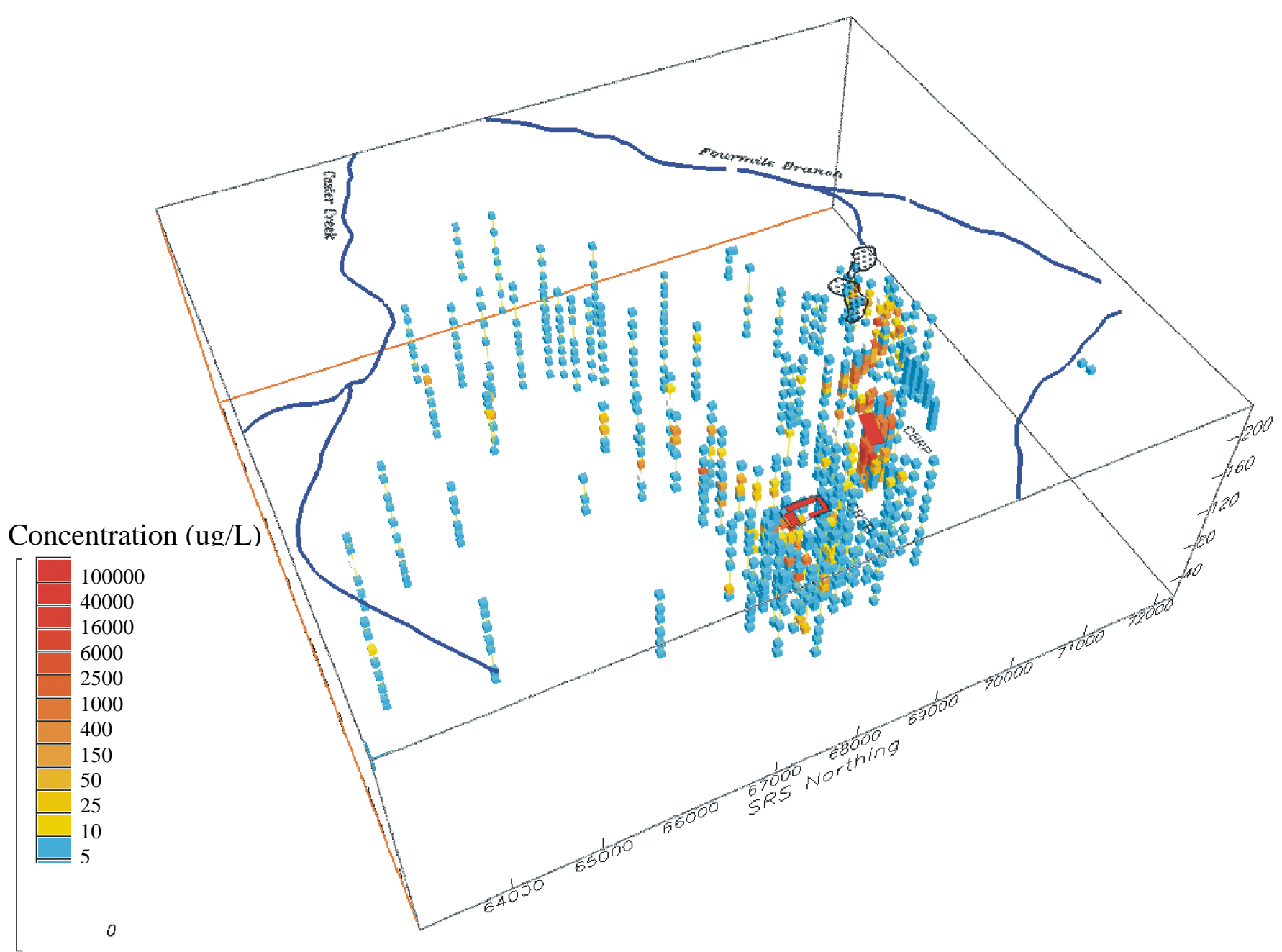

Figure 2-3. EarthVision ${ }^{\varpi}$ Visualization of TCE Concentrations beneath the Model Area 


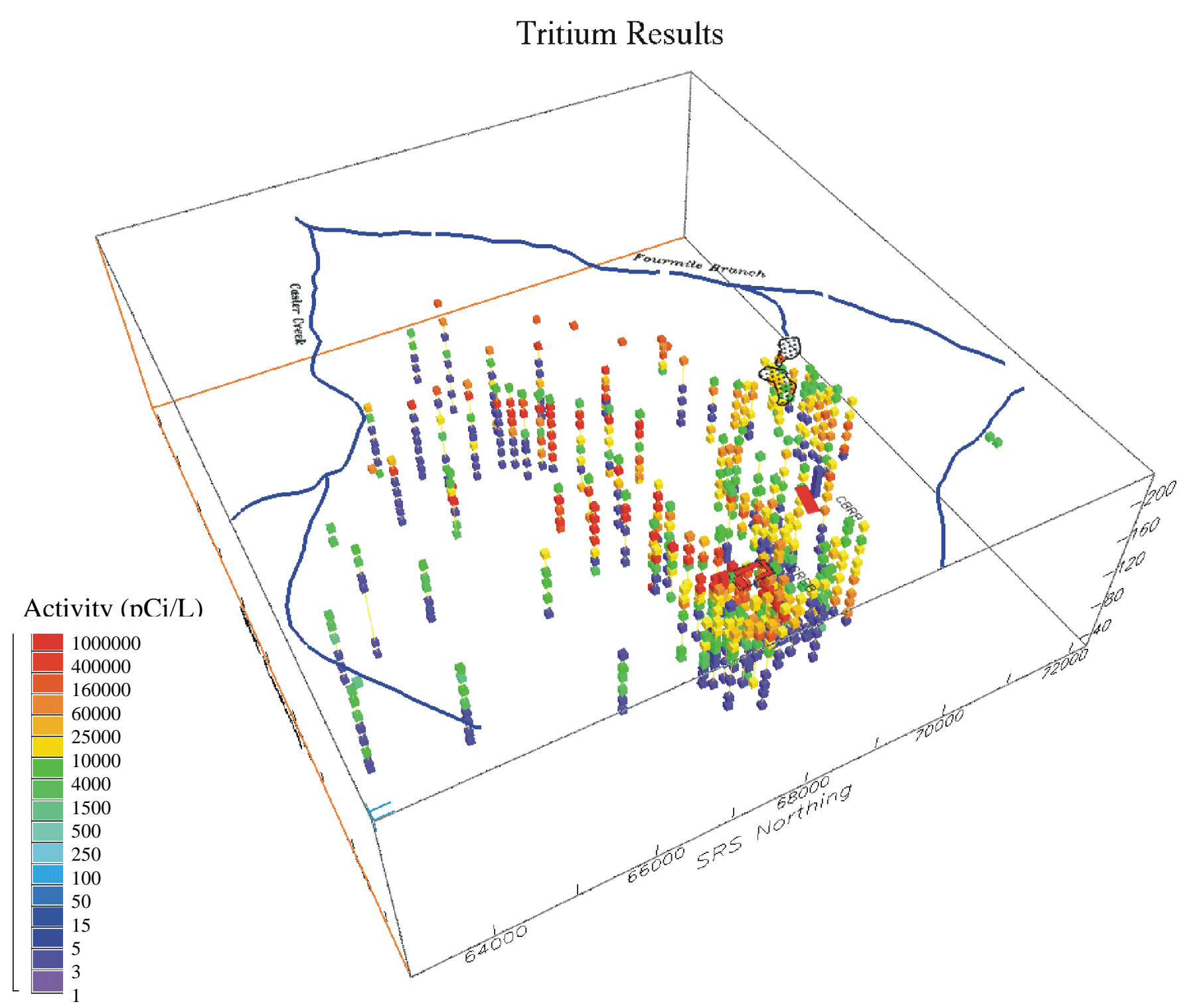

Figure 2-4. $\quad$ Earth Vision ${ }^{\circledR}$ Visualization of Tritium Concentrations beneath the Model Area 


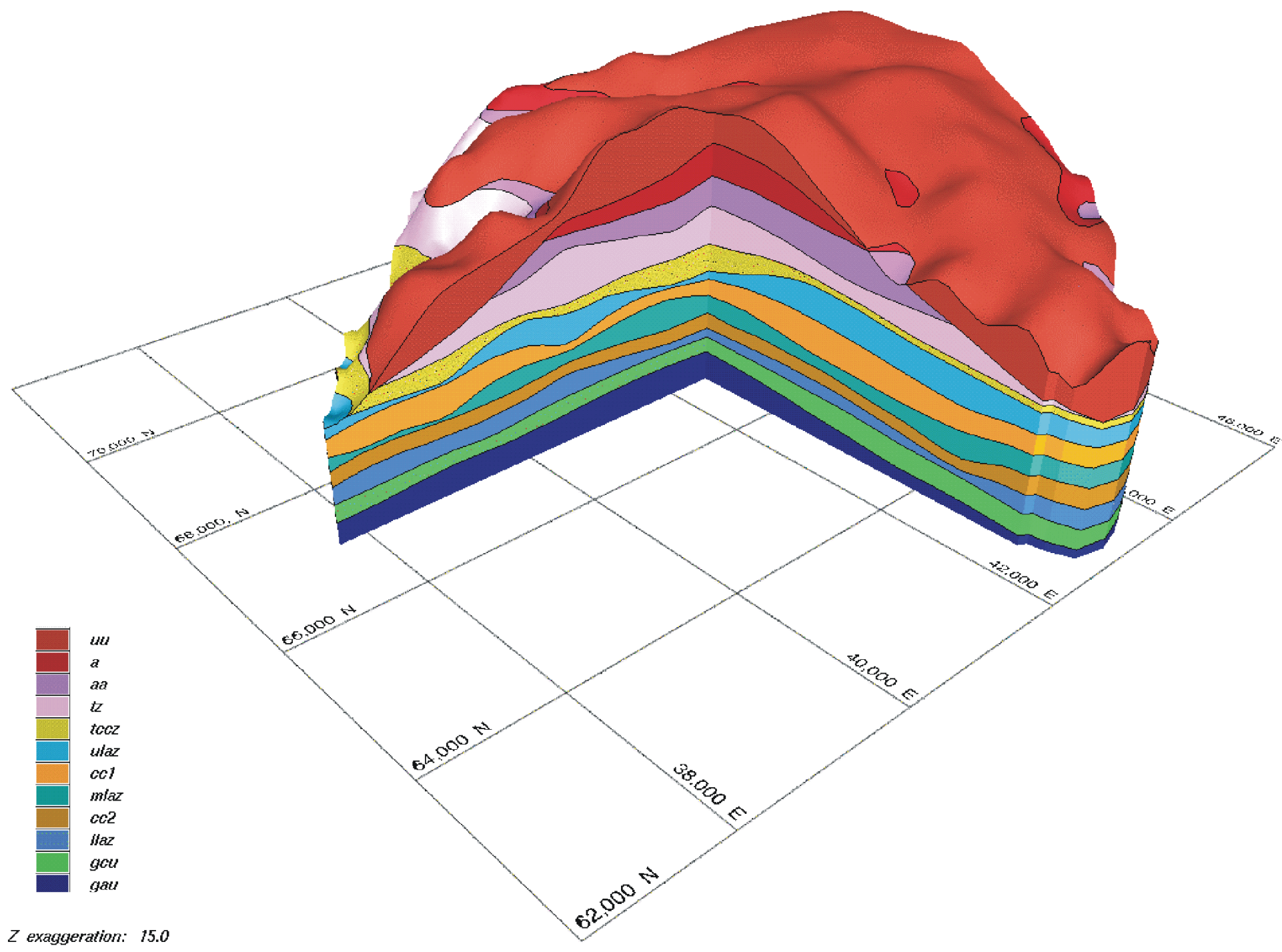

Figure 2-5. Conceptual Hydrostratigraphic Model for C Reactor Area 


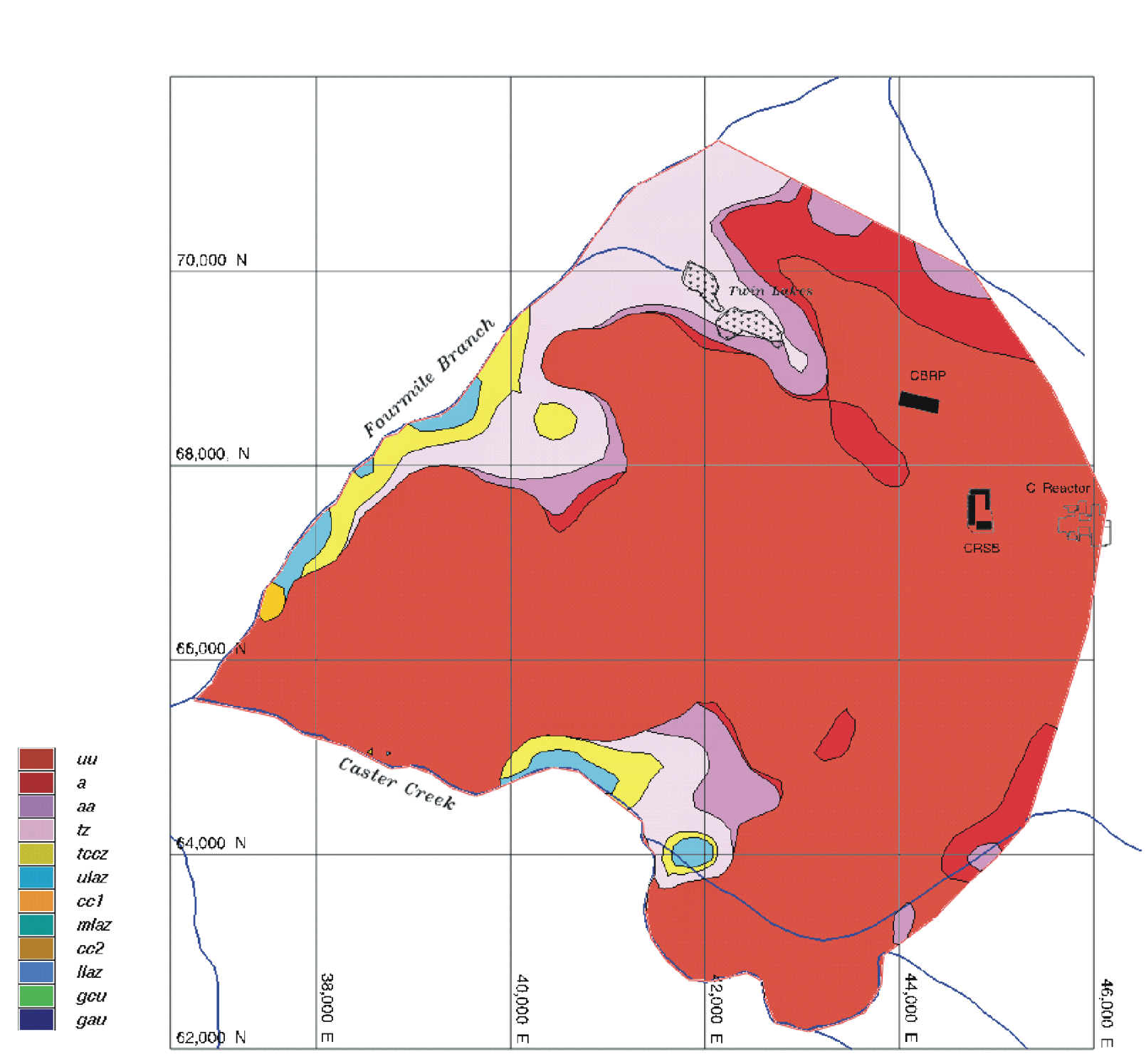

Figure 2-6. Outcrop Map of Hydrostratigraphic Units 

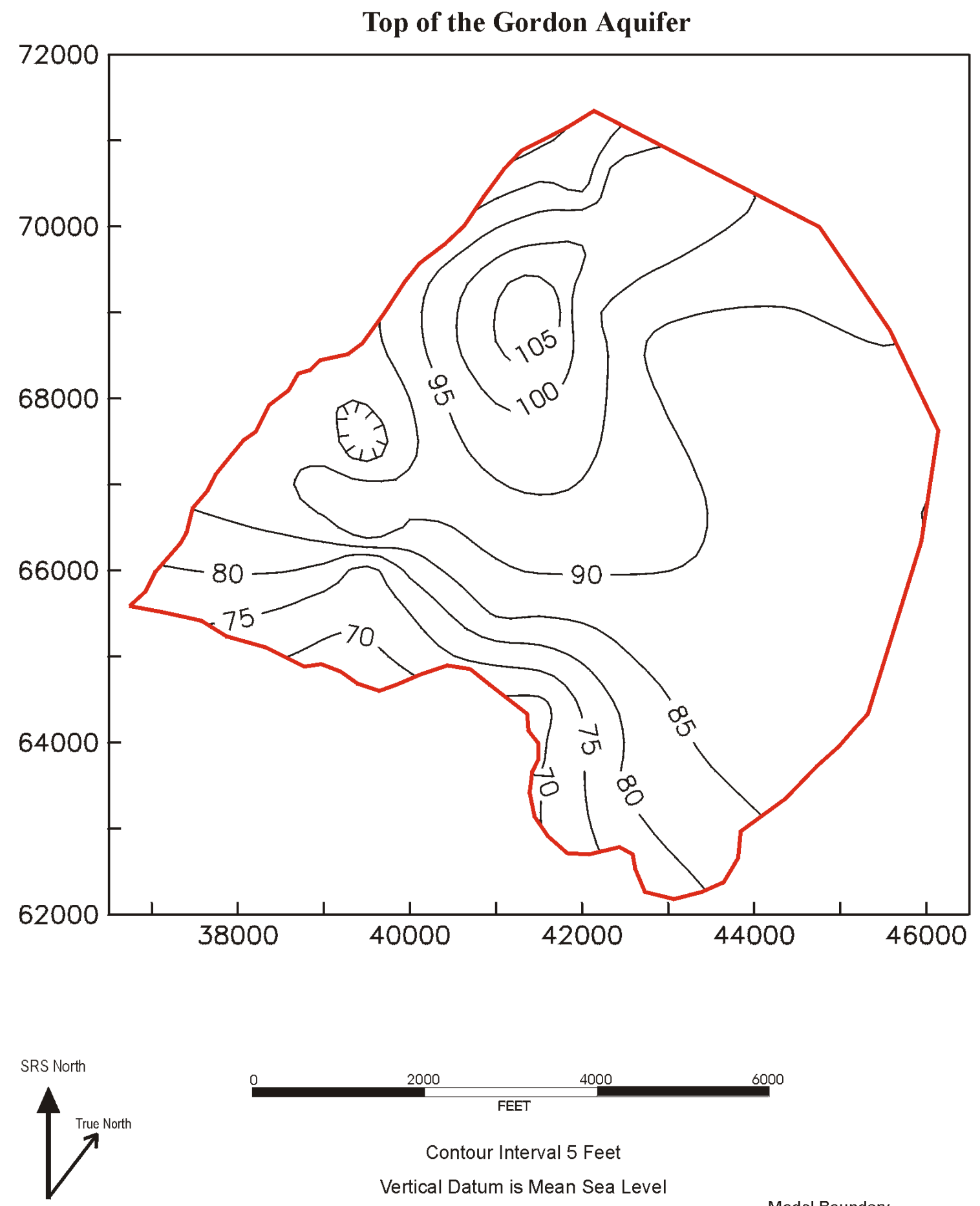

Model Boundary

Figure 2-7. Altitude-Contour Map of the Top of the Gordon Aquifer 


\section{Top of the Gordon Confining Unit}
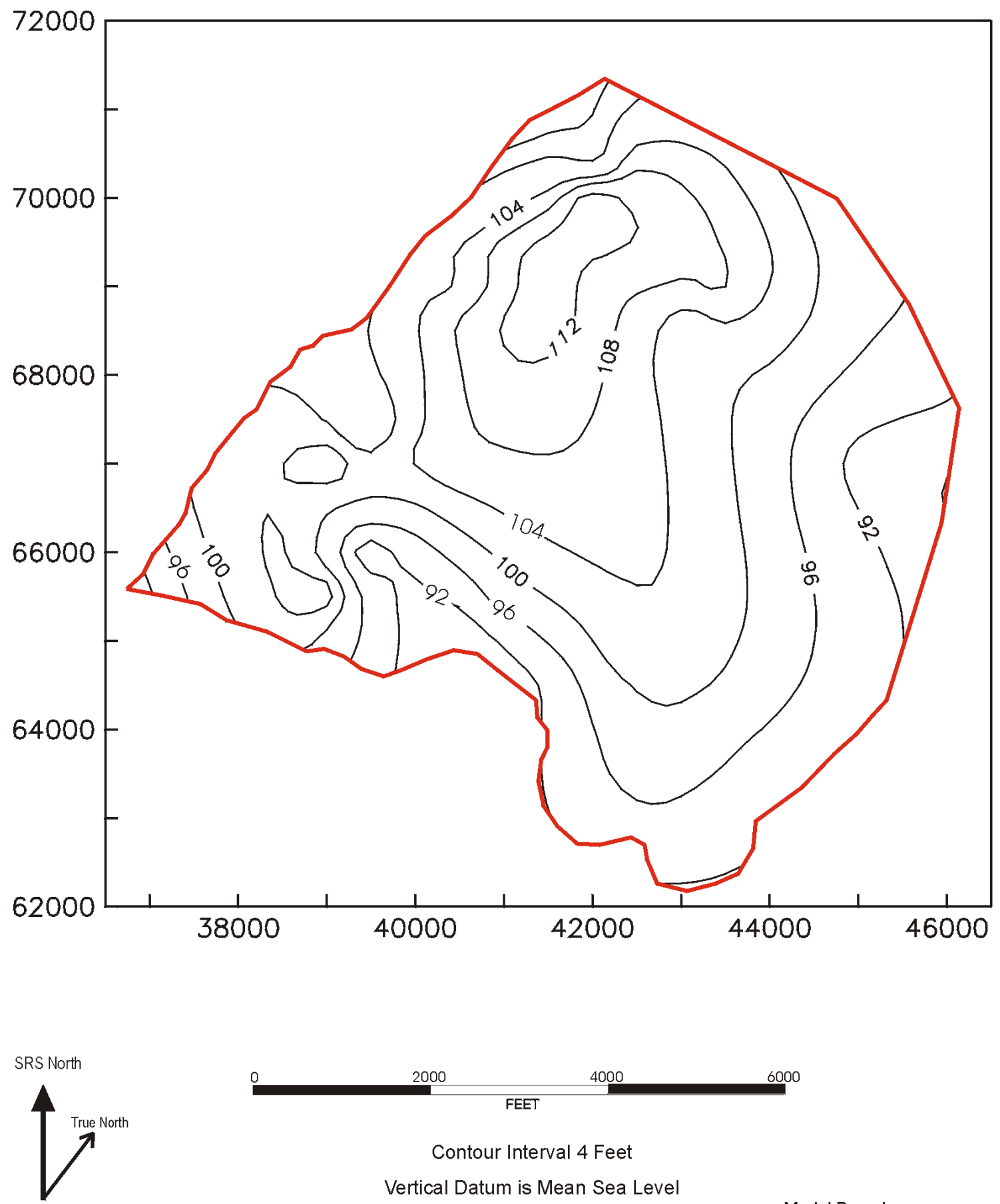

Vertical Datum is Mean Sea Level

Model Boundary

Figure 2-8. Altitude-Contour Map of the Top of the Gordon Confining Unit 

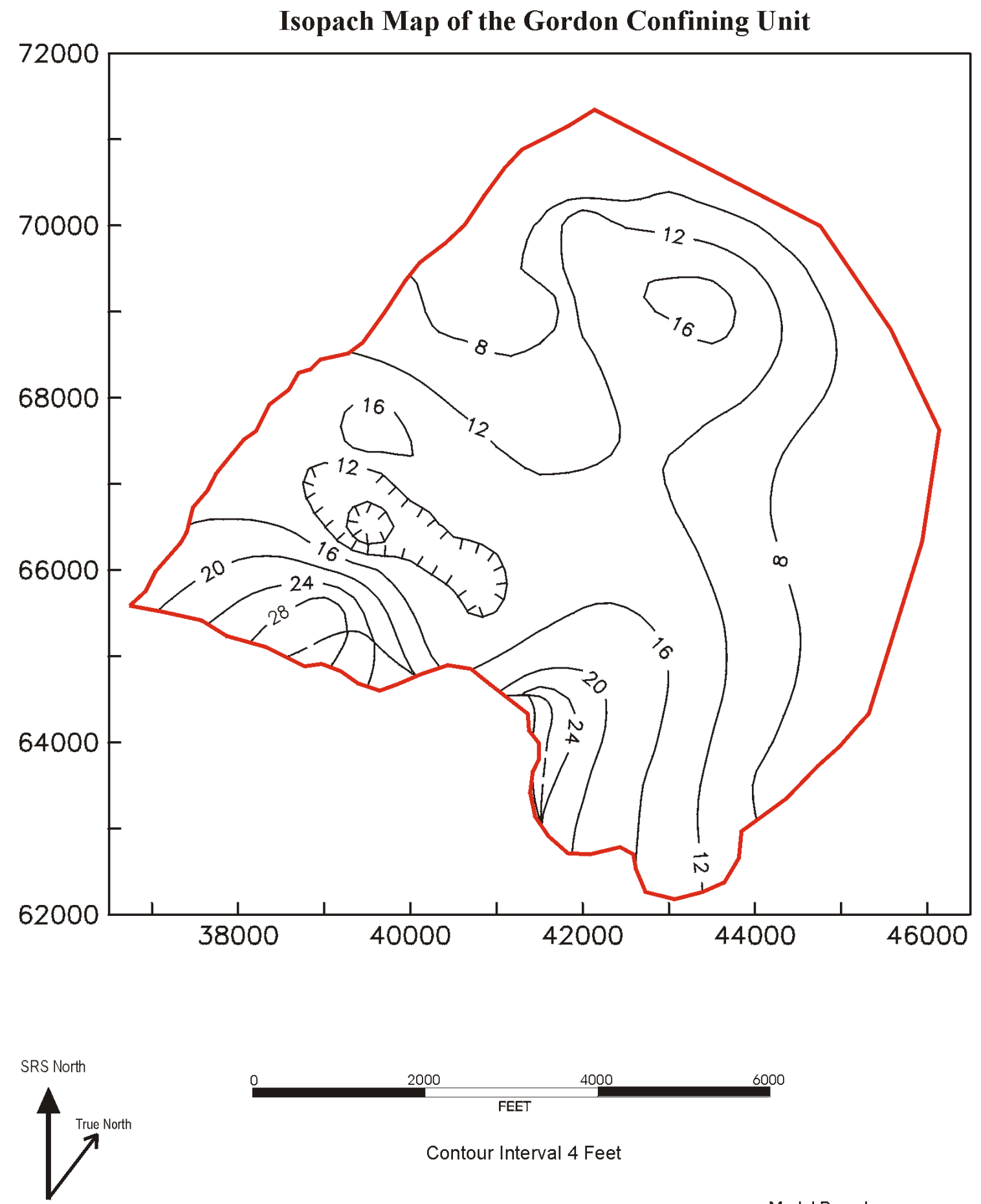

Model Boundary

Figure 2-9. Isopach Map of the Gordon Confining Unit 


\section{Top of the "LLAZ"}

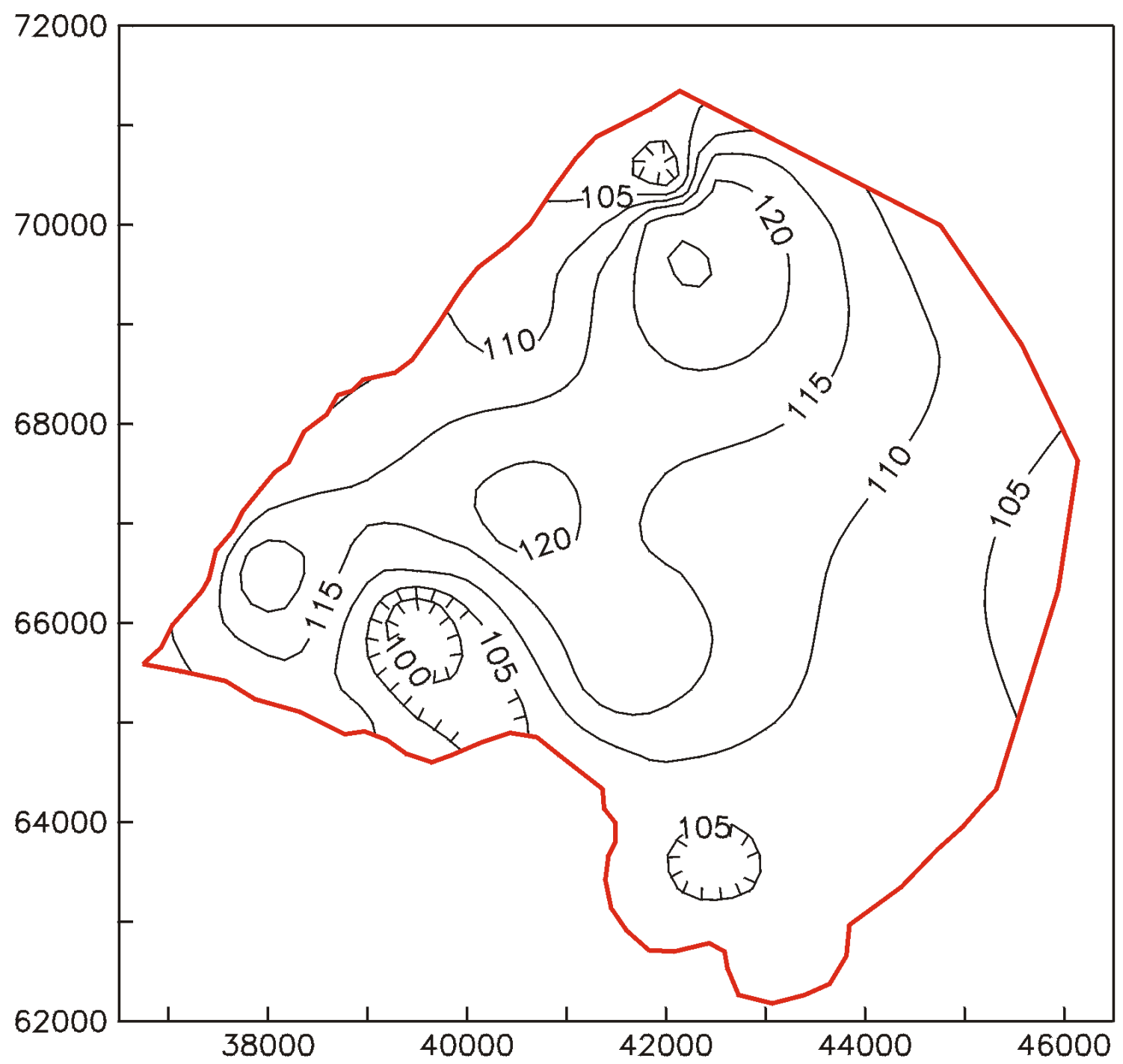

SRS North

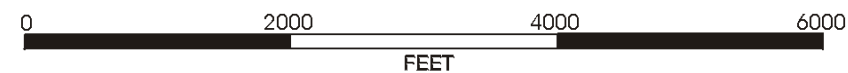

Contour Interval 5 Feet

Vertical Datum is Mean Sea Level

Model Boundary

Figure 2-10. Altitude-Contour Map of the Top of the Lower Interval of the "Lower" Aquifer Zone 

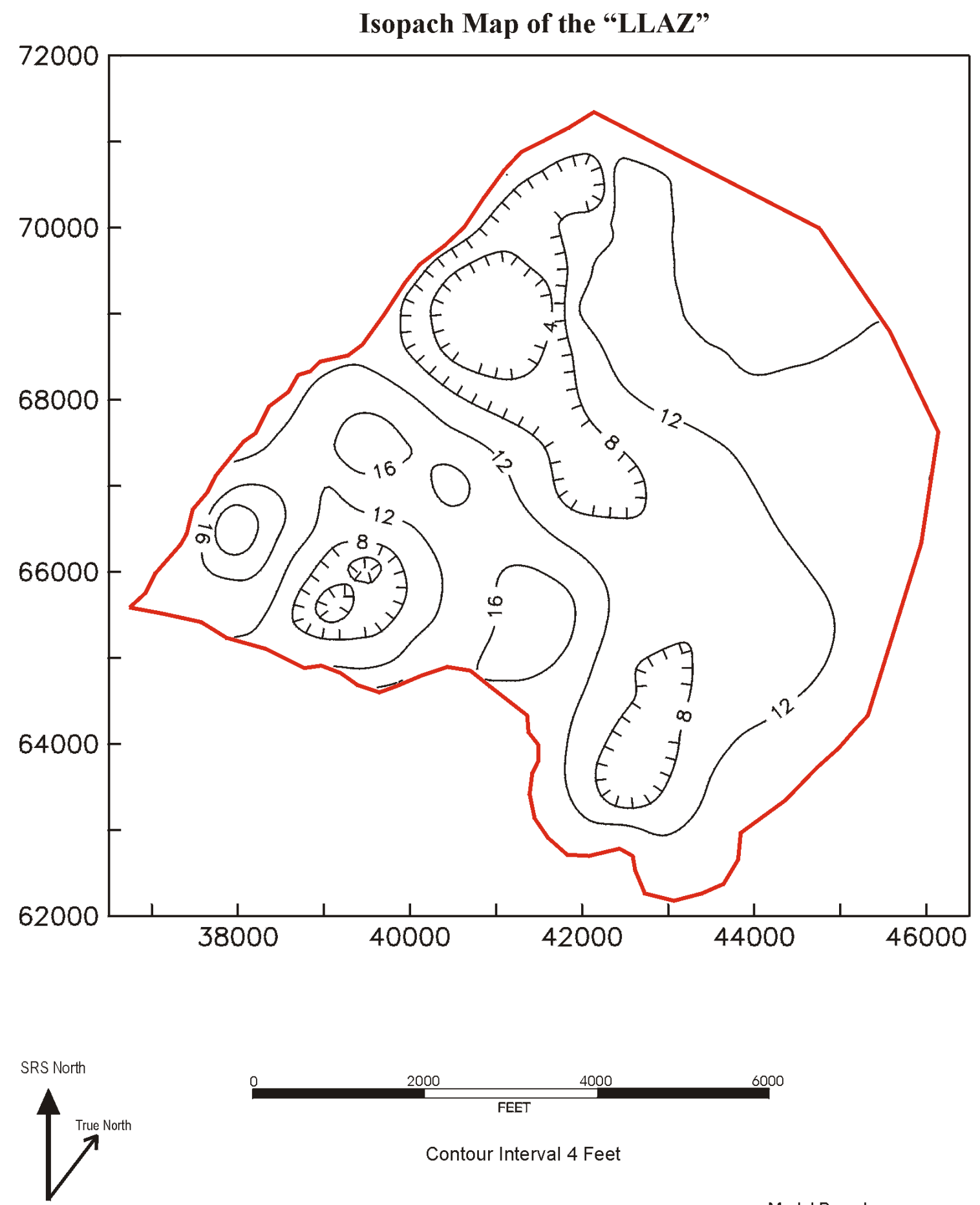

Contour Interval 4 Feet

Model Boundary

Figure 2-11. Isopach Map of the Lower Interval of the "Lower" Aquifer Zone 


\section{Top of the "CC2" Interval}
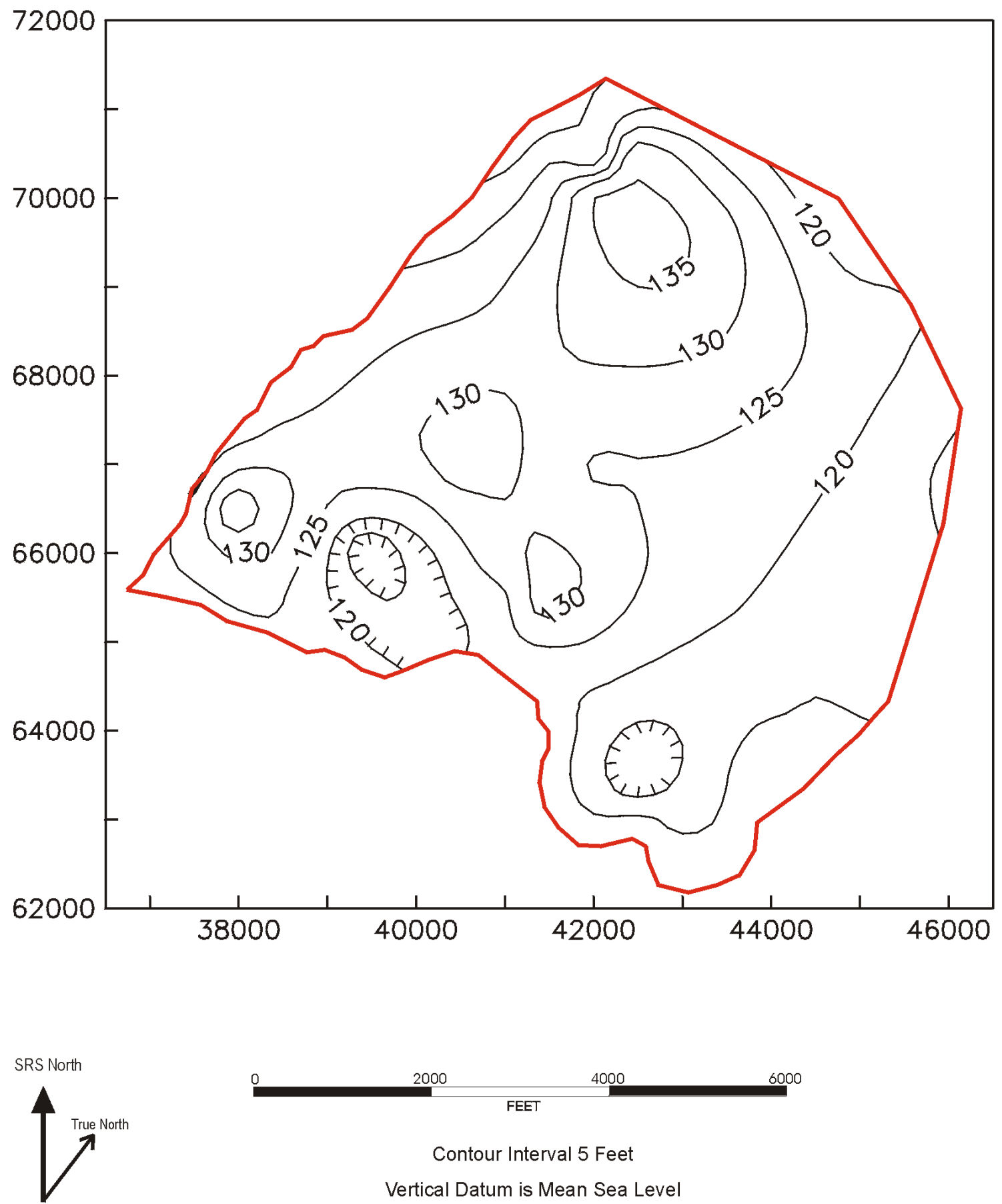

Model Boundary

Figure 2-12. Altitude-Contour Map of the Top of the Lower Carbonate Interval (CC2) within the "Lower" Aquifer Zone 

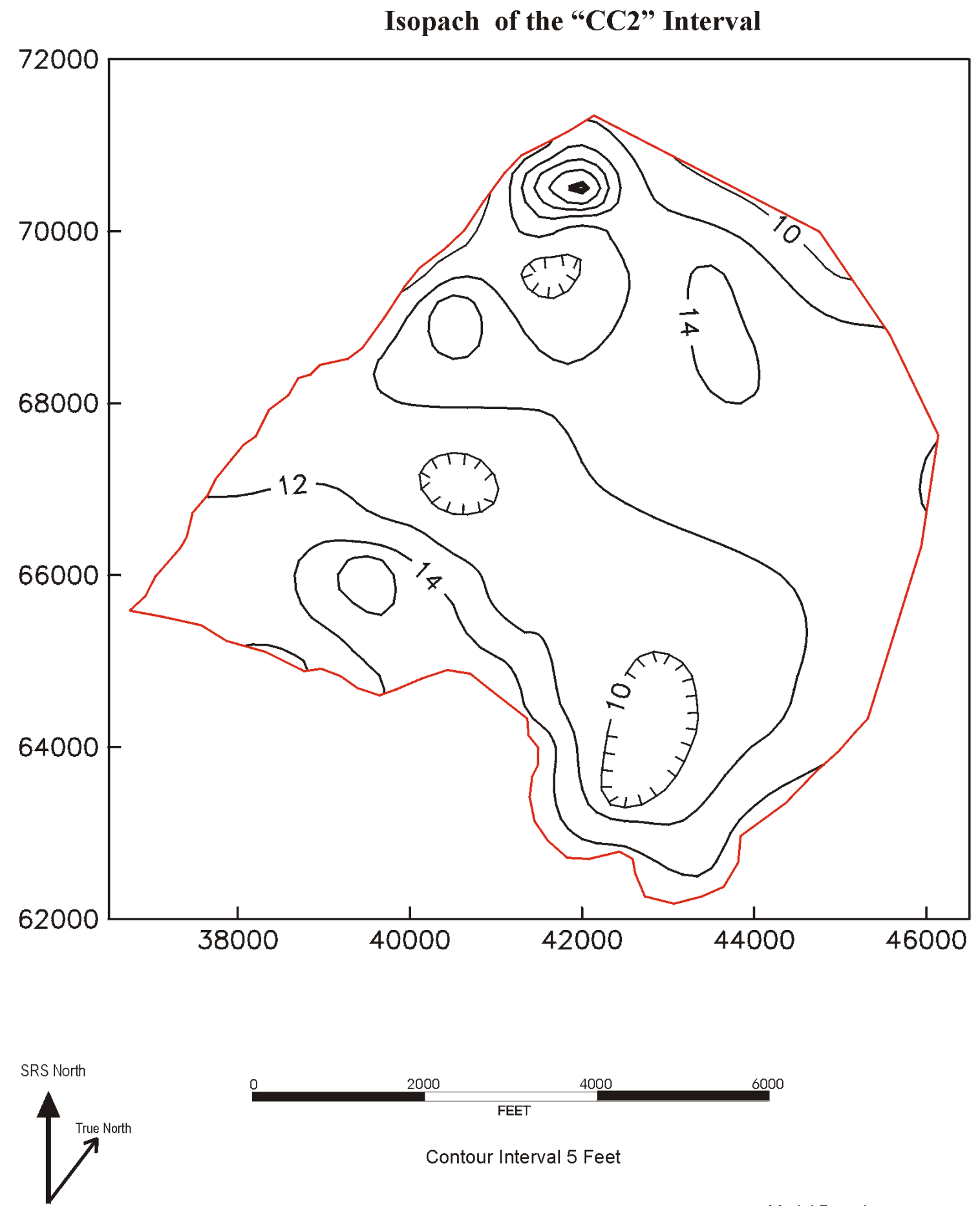

Contour Interval 5 Feet

Model Boundary

Figure 2-13. Isopach Map of the Lower Carbonate Interval (CC2) within the "Lower" Aquifer Zone 

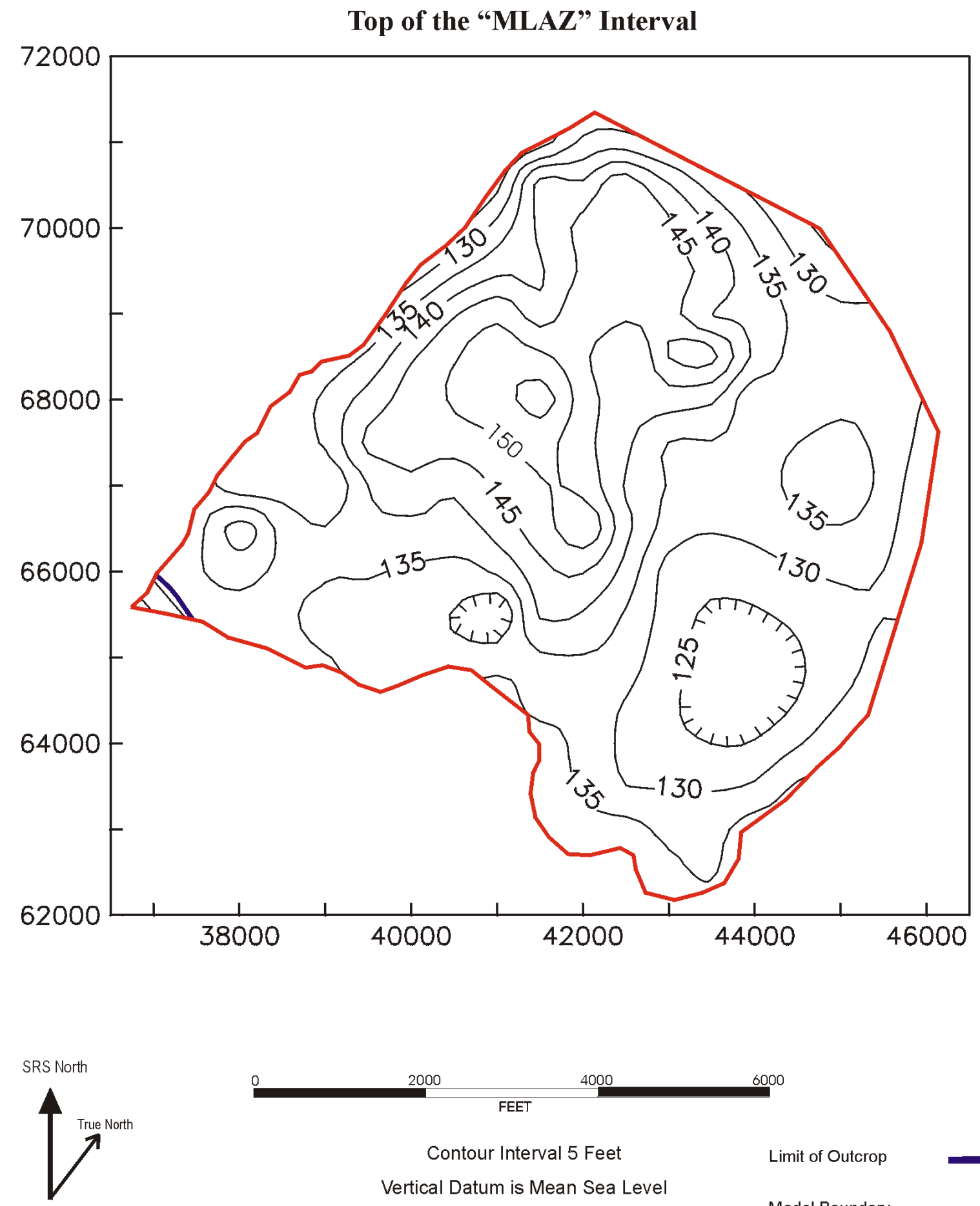

Contour Interval 5 Feet

Limit of Outcrop

Vertical Datum is Mean Sea Level

Model Boundary

Figure 2-14. Altitude-Contour Map of the Top of the Middle Interval of the"Lower" Aquifer Zone 

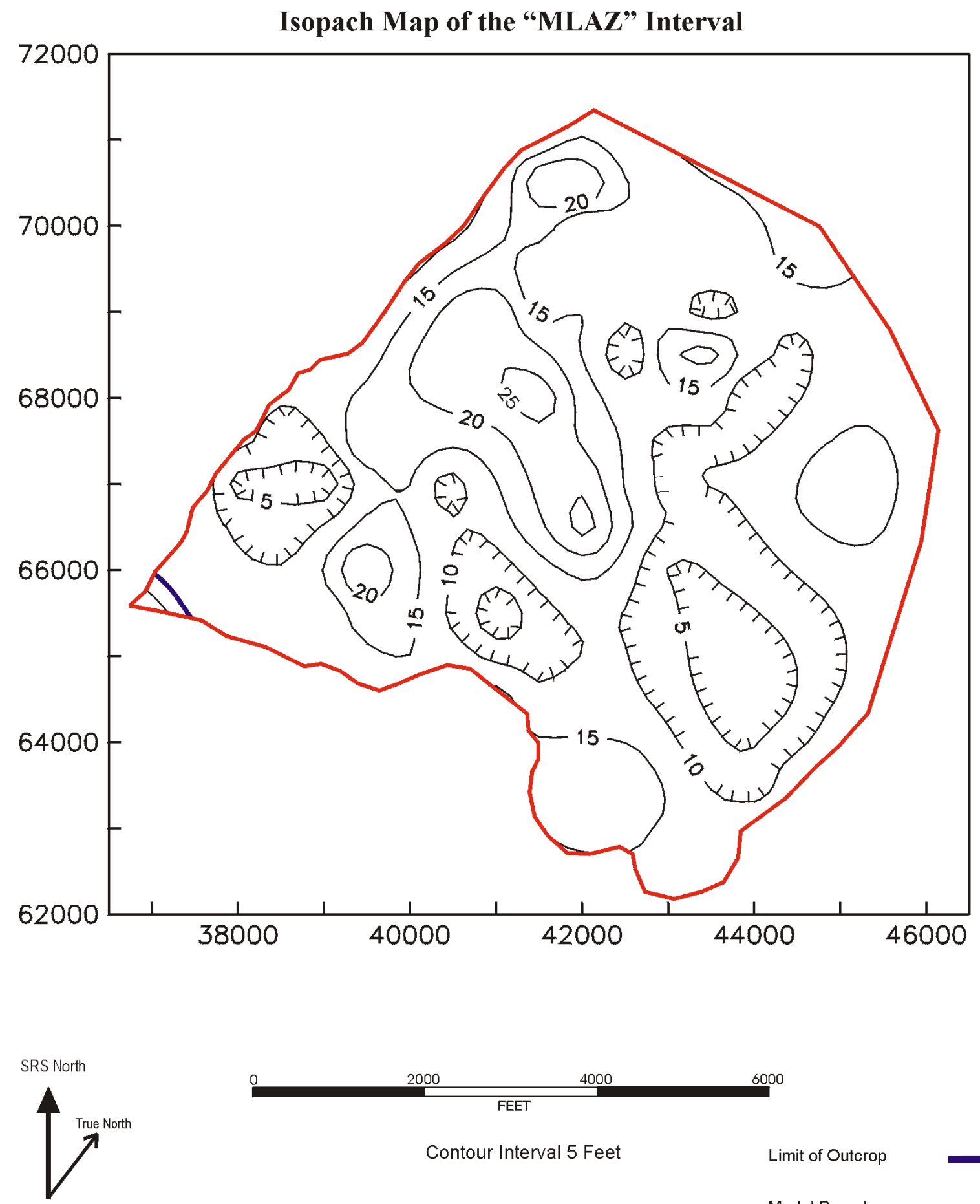

Contour Interval 5 Feet

Limit of Outcrop

Model Boundary

Figure 2-15. Isopach Map of the Middle Interval of the "Lower" Aquifer Zone 

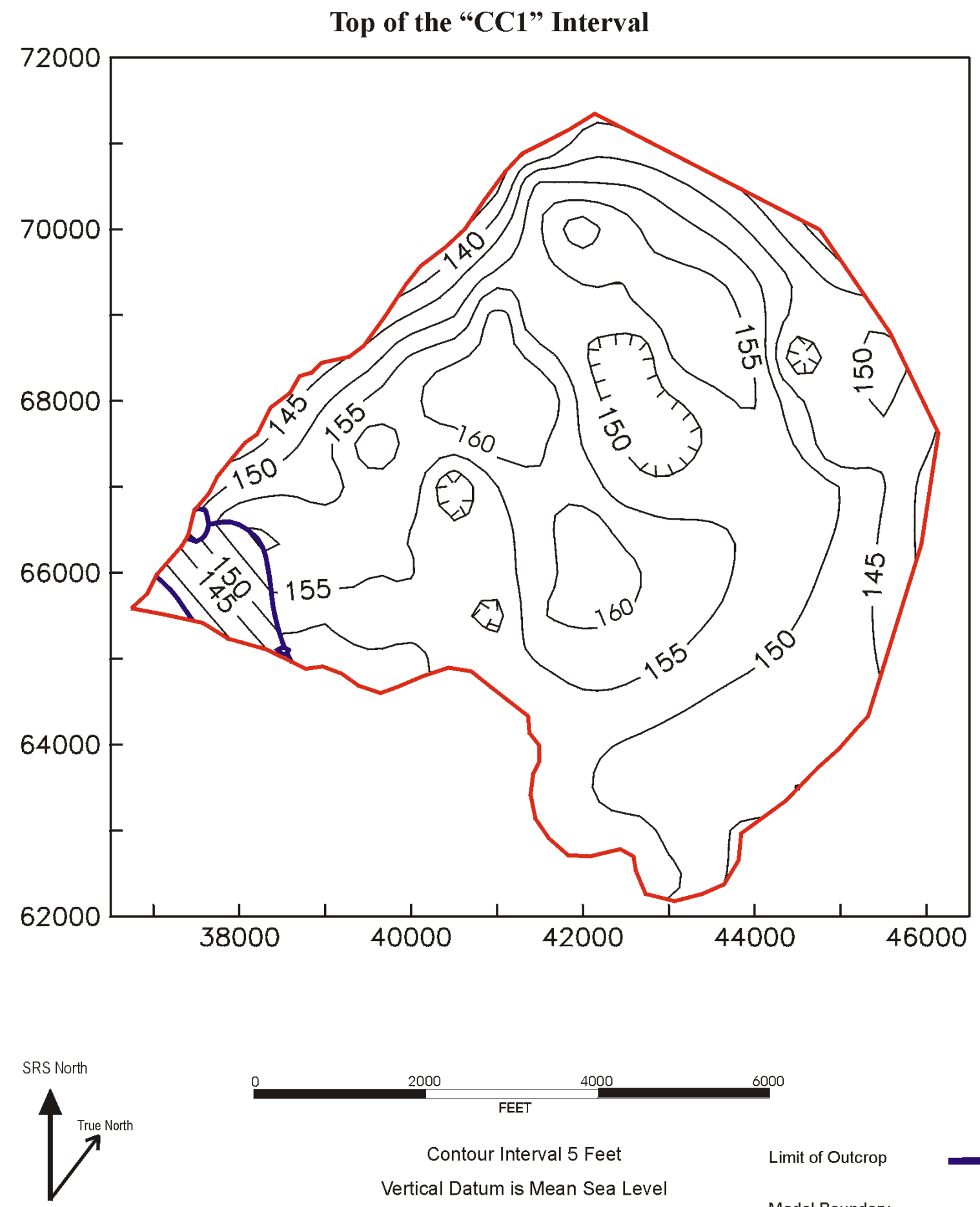

Contour Interval 5 Feet

Limit of Outcrop

Vertical Datum is Mean Sea Level

Model Boundary

Figure 2-16. Altitude-Contour Map of the Top of the Upper Carbonate Interval (CC1) within the "Lower" Aquifer Zone 

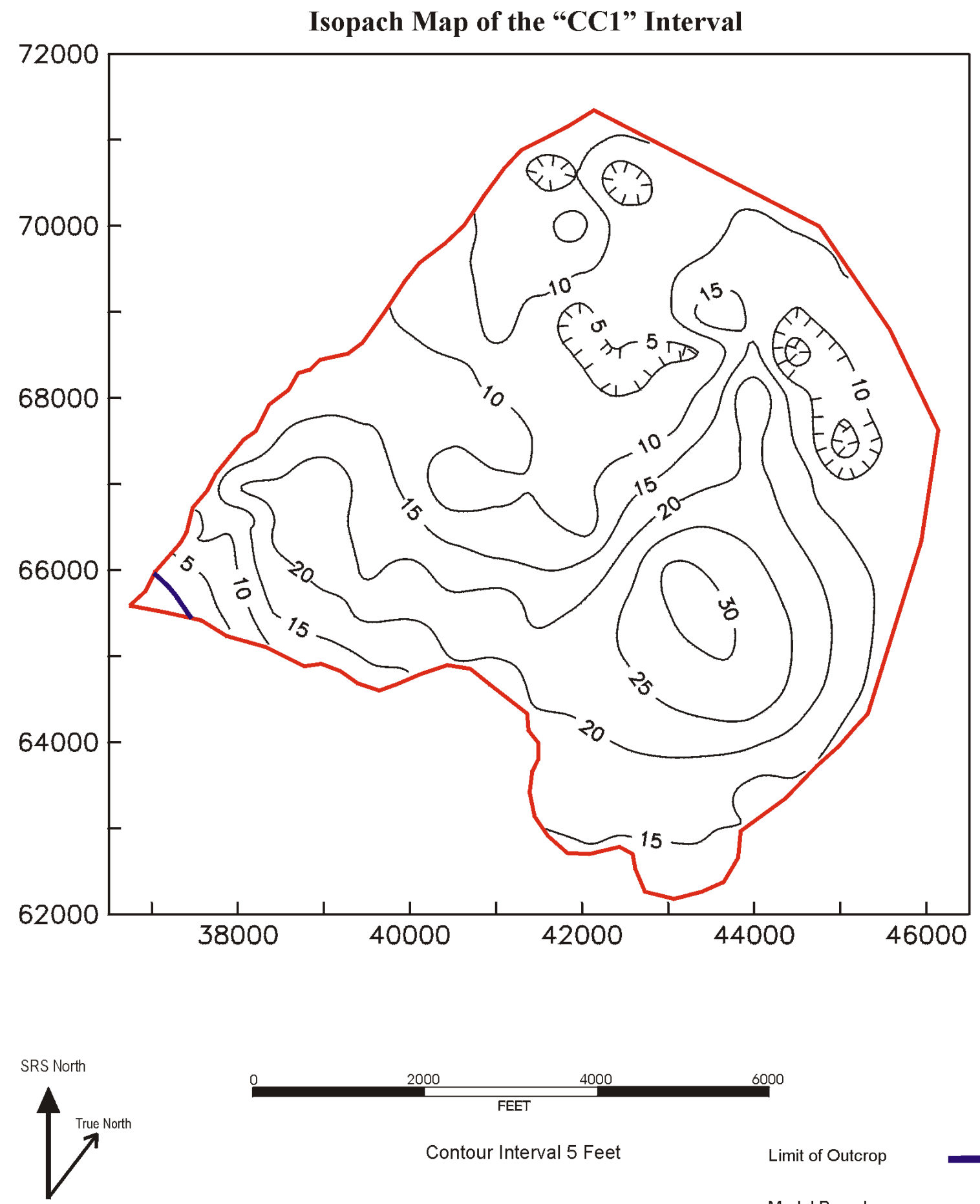

Contour Interval 5 Feet

Limit of Outcrop

Model Boundary

Figure 2-17. Isopach Map of the Upper Carbonate Interval (CC1) within the "Lower" Aquifer Zone 

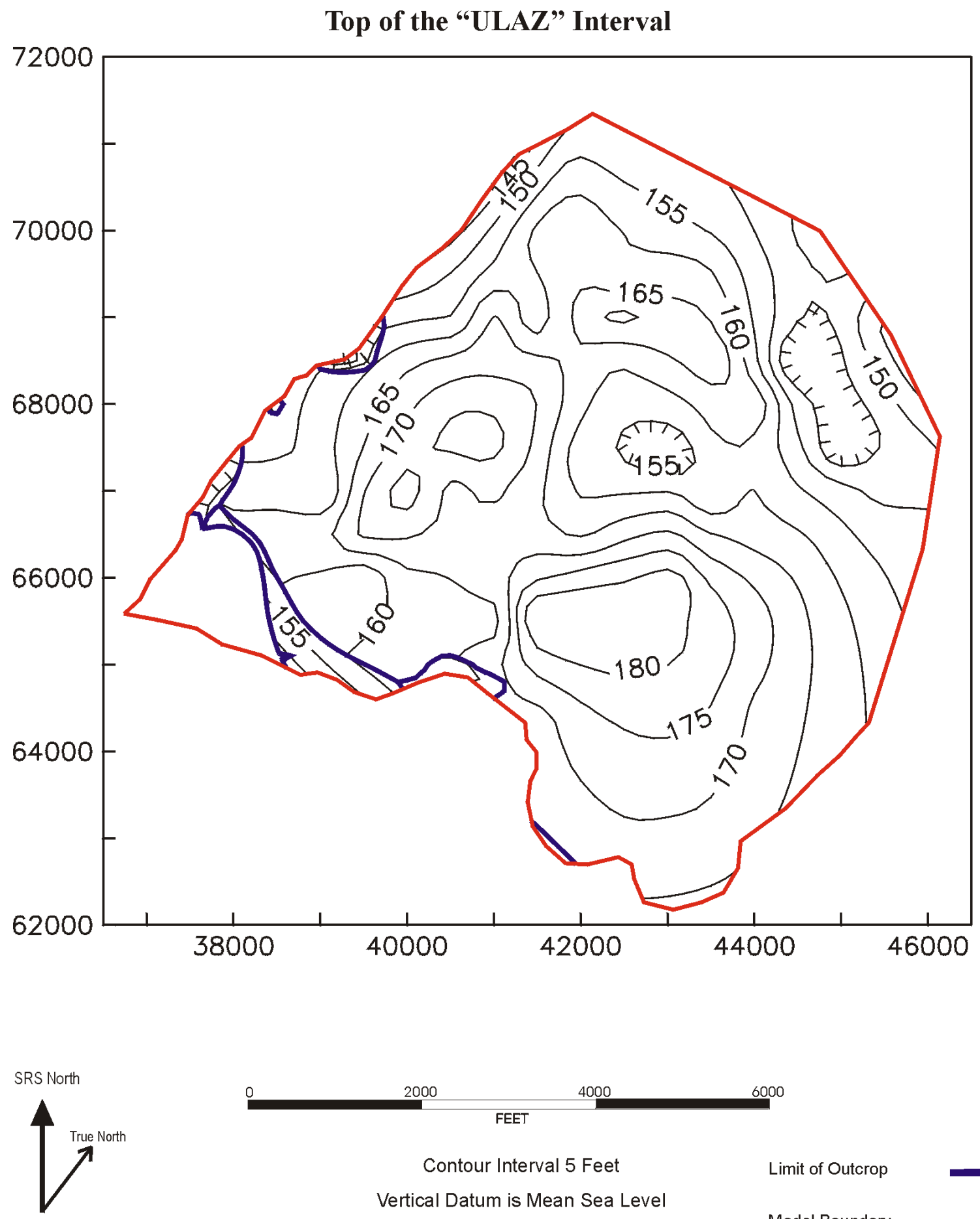

Contour Interval 5 Feet

Limit of Outcrop

Vertical Datum is Mean Sea Level

Model Boundary

Figure 2-18. Altitude-Contour Map of the Top of the Upper Interval of the "Lower" Aquifer Zone 

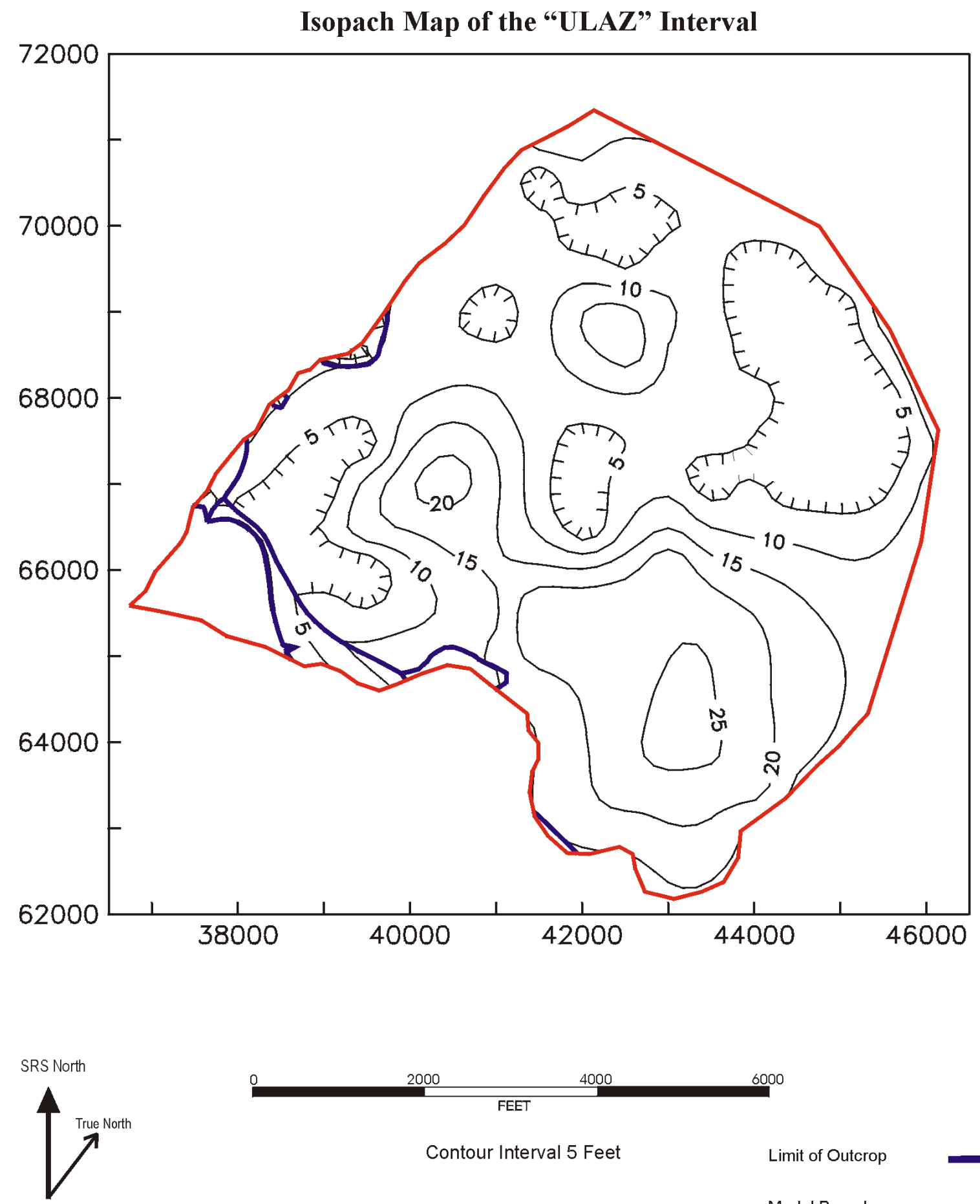

Contour Interval 5 Feet

Limit of Outcrop

Model Boundary

Figure 2-19. Isopach Map of the Upper Interval of the "Lower" Aquifer Zone 

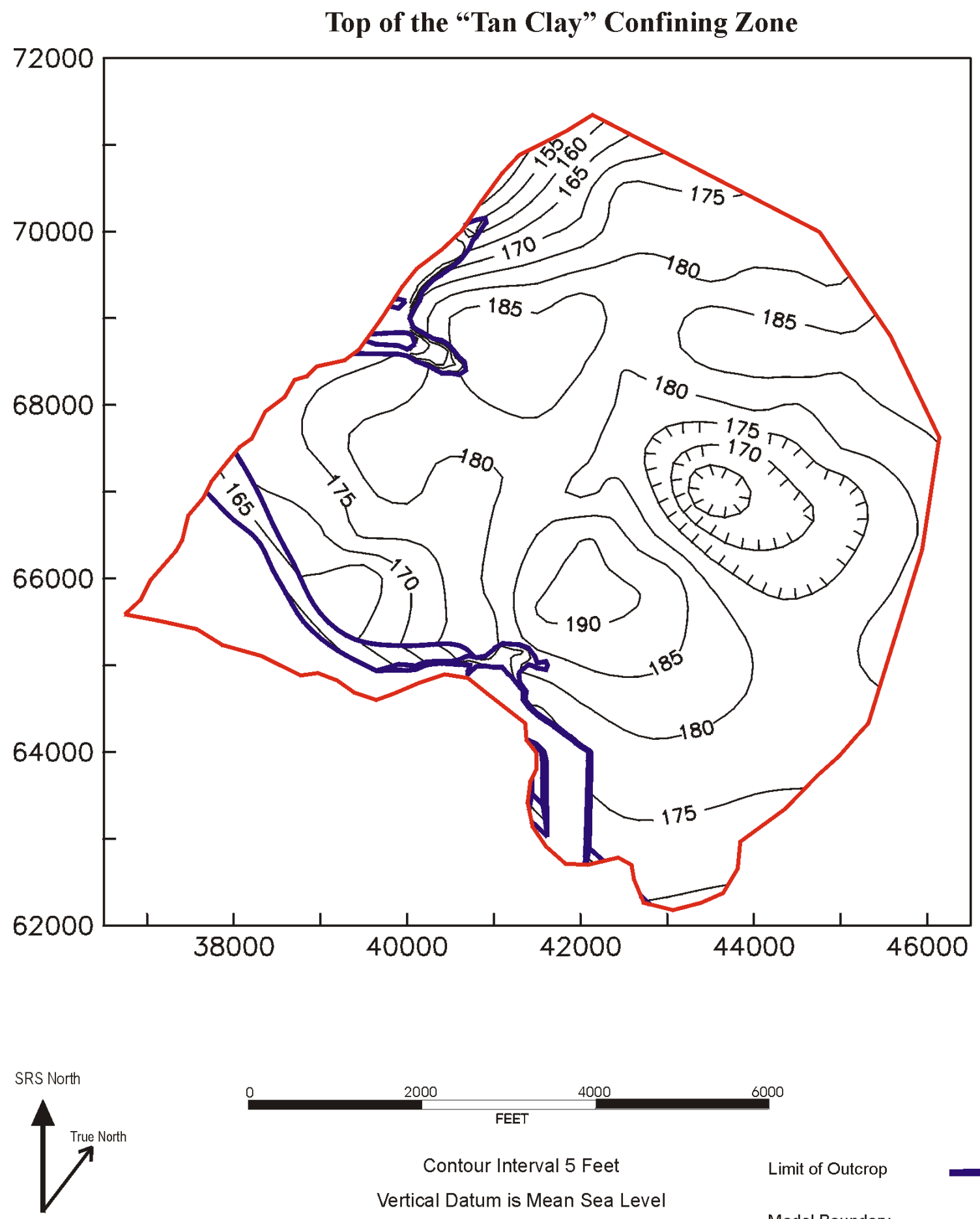

Contour Interval 5 Feet

Limit of Outcrop

Vertical Datum is Mean Sea Level

Model Boundary

Figure 2-20. Altitude-Contour Map of the Top of the "Tan Clay" Confining Zone 

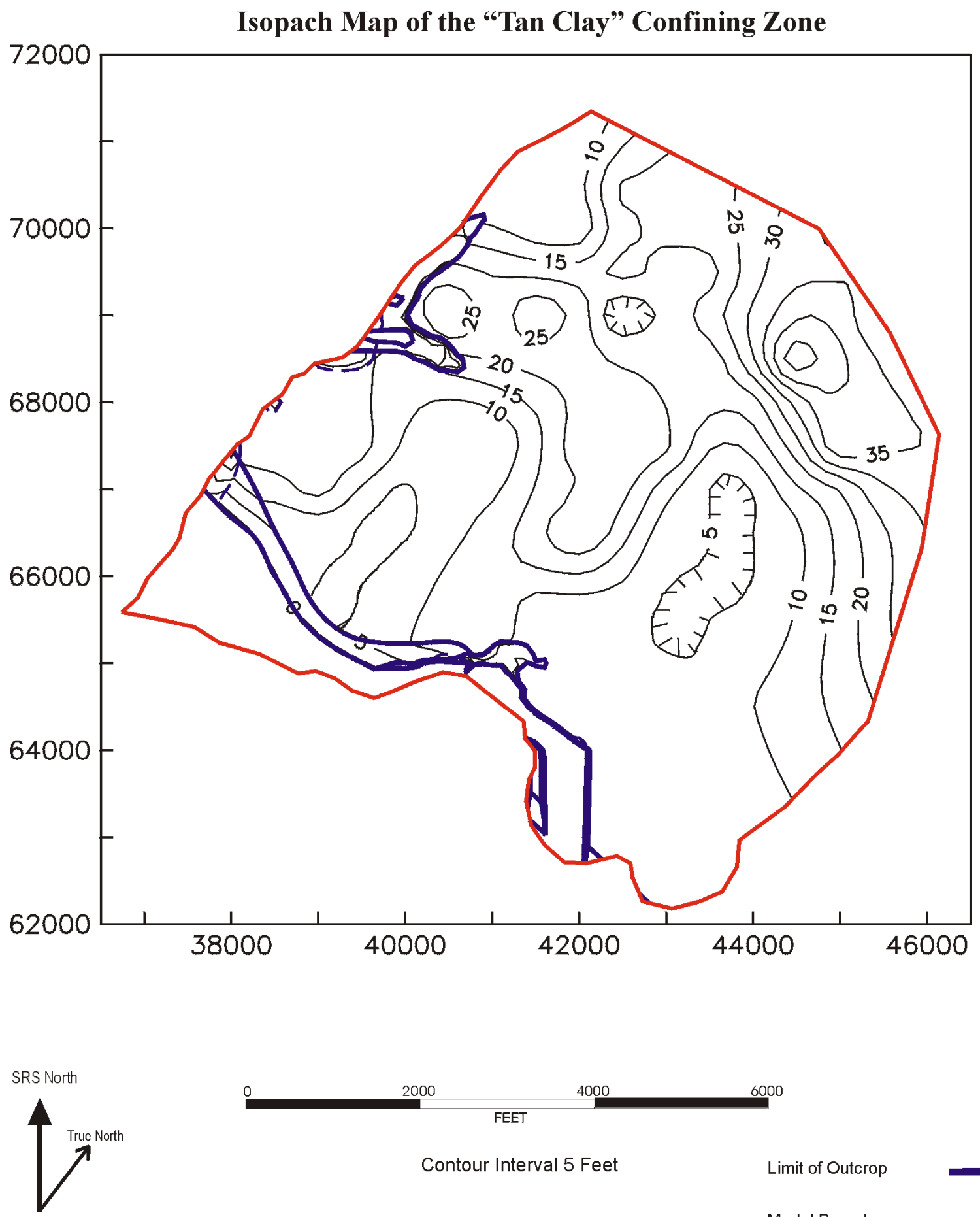

Contour Interval 5 Feet

Limit of Outcrop

Model Boundary

Figure 2-21. Isopach Map of the "Tan Clay" Confining Zone 


\section{Top of the Transmissive Zone}
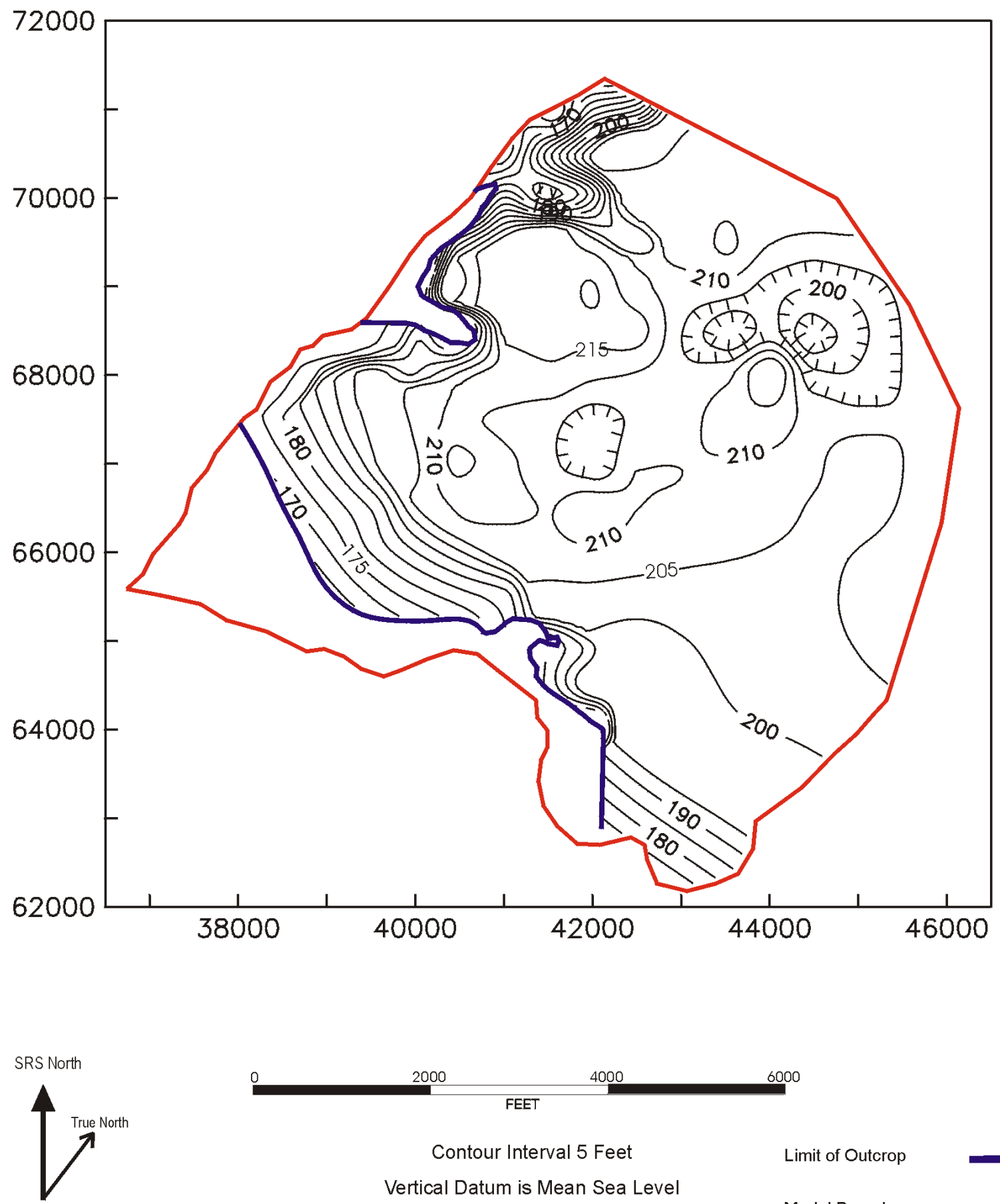

Contour Interval 5 Feet

Limit of Outcrop

Vertical Datum is Mean Sea Level

Model Boundary

Figure 2-22. Altitude-Contour Map of the Top of the "Transmissive Zone" 

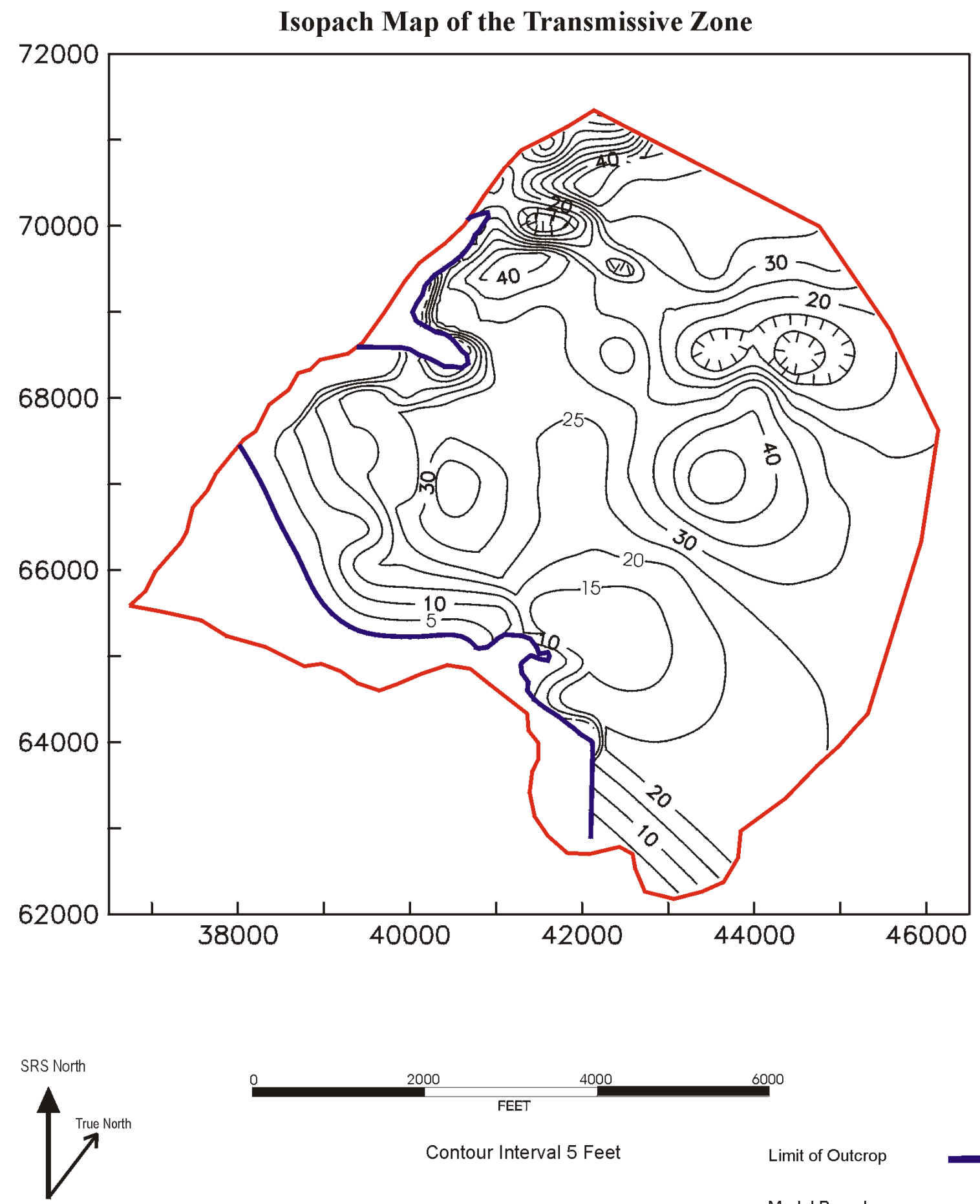

Contour Interval 5 Feet

Limit of Outcrop

Model Boundary

Figure 2-23. Isopach Map of the "Transmissive Zone" 

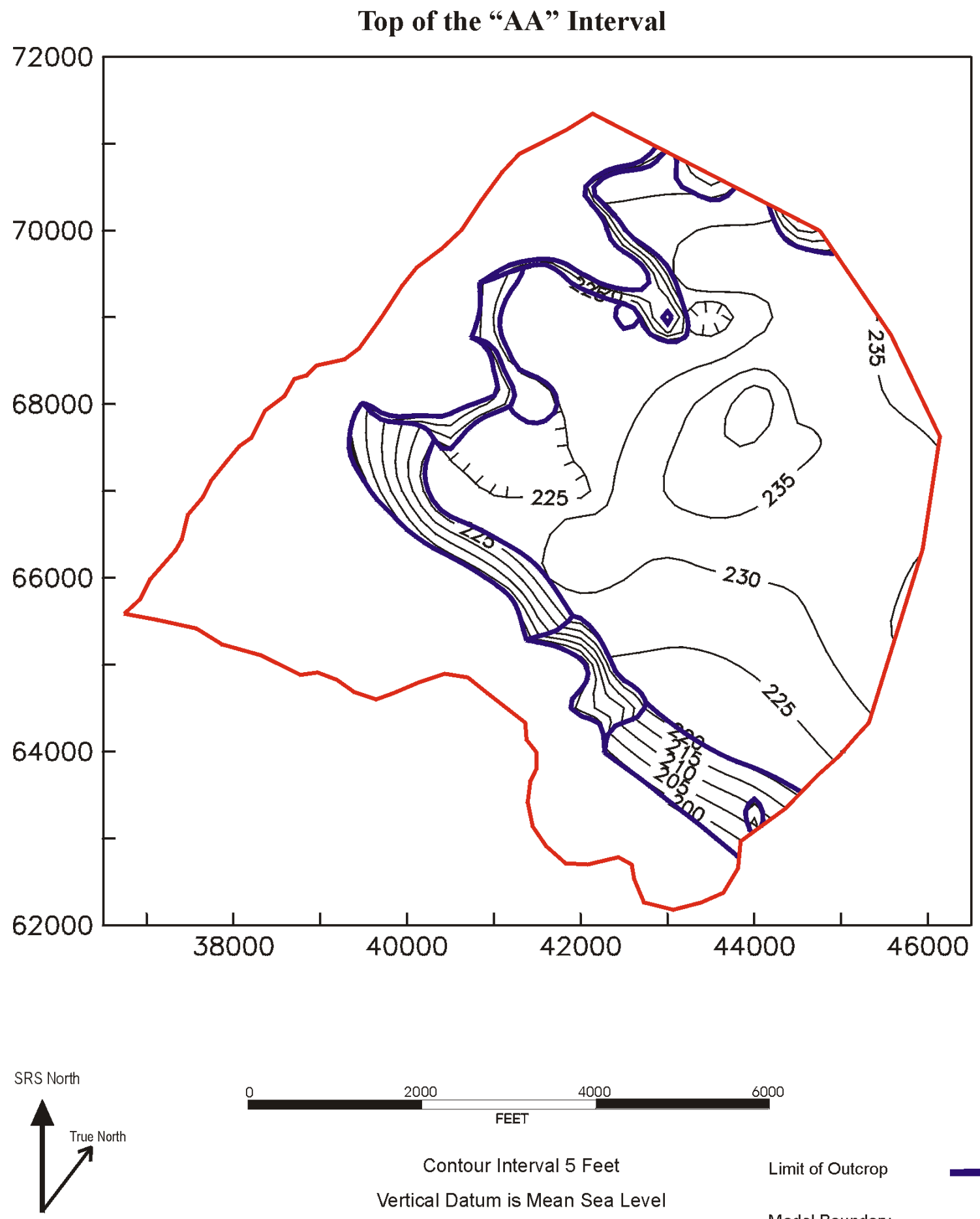

Contour Interval 5 Feet

Limit of Outcrop

Vertical Datum is Mean Sea Level

Model Boundary

Figure 2-24. Altitude-Contour Map of the Top of the "AA" Interval 

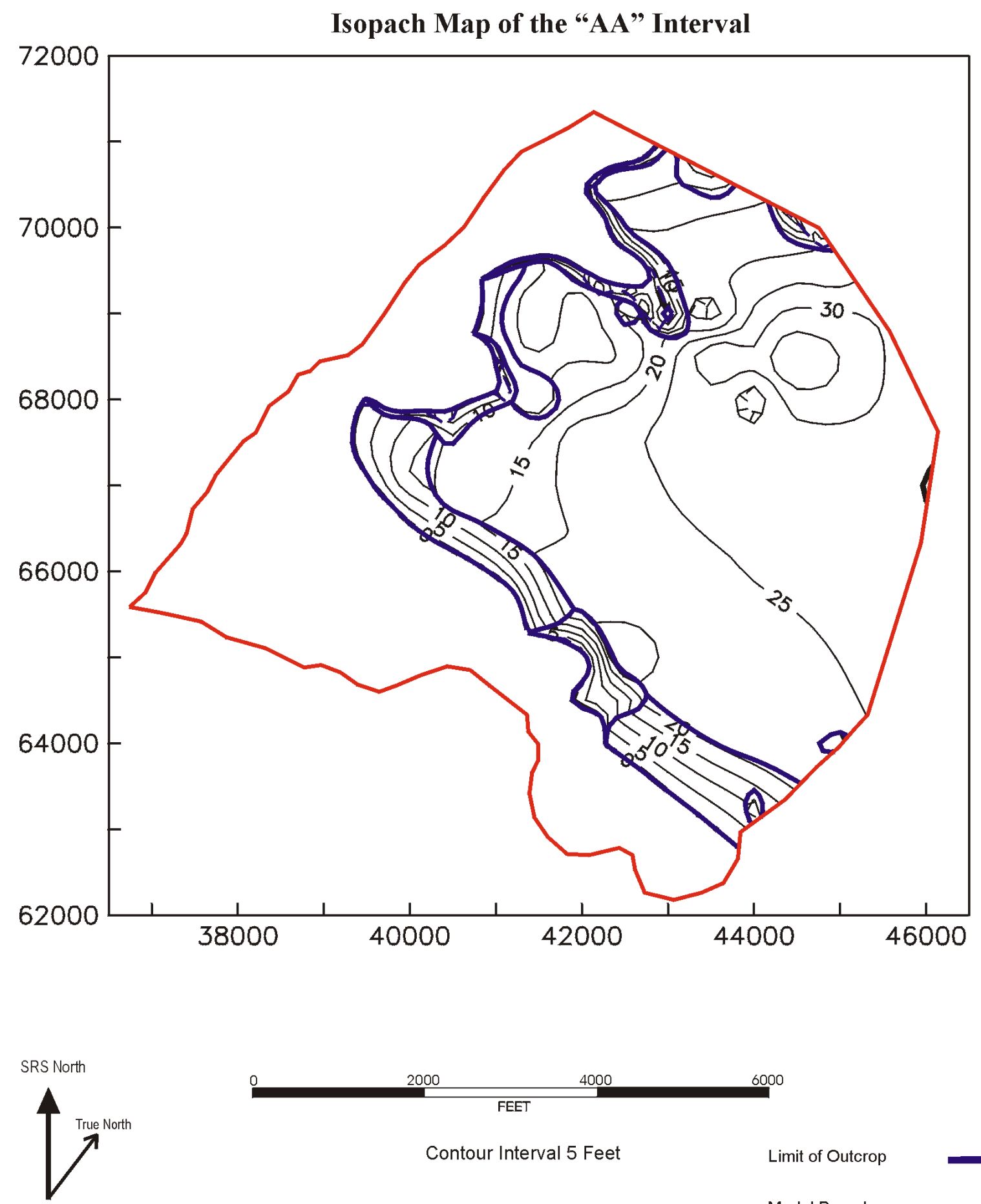

Contour Interval 5 Feet

Limit of Outcrop

Model Boundary

Figure 2-25. Isopach Map of the "AA" Interval 

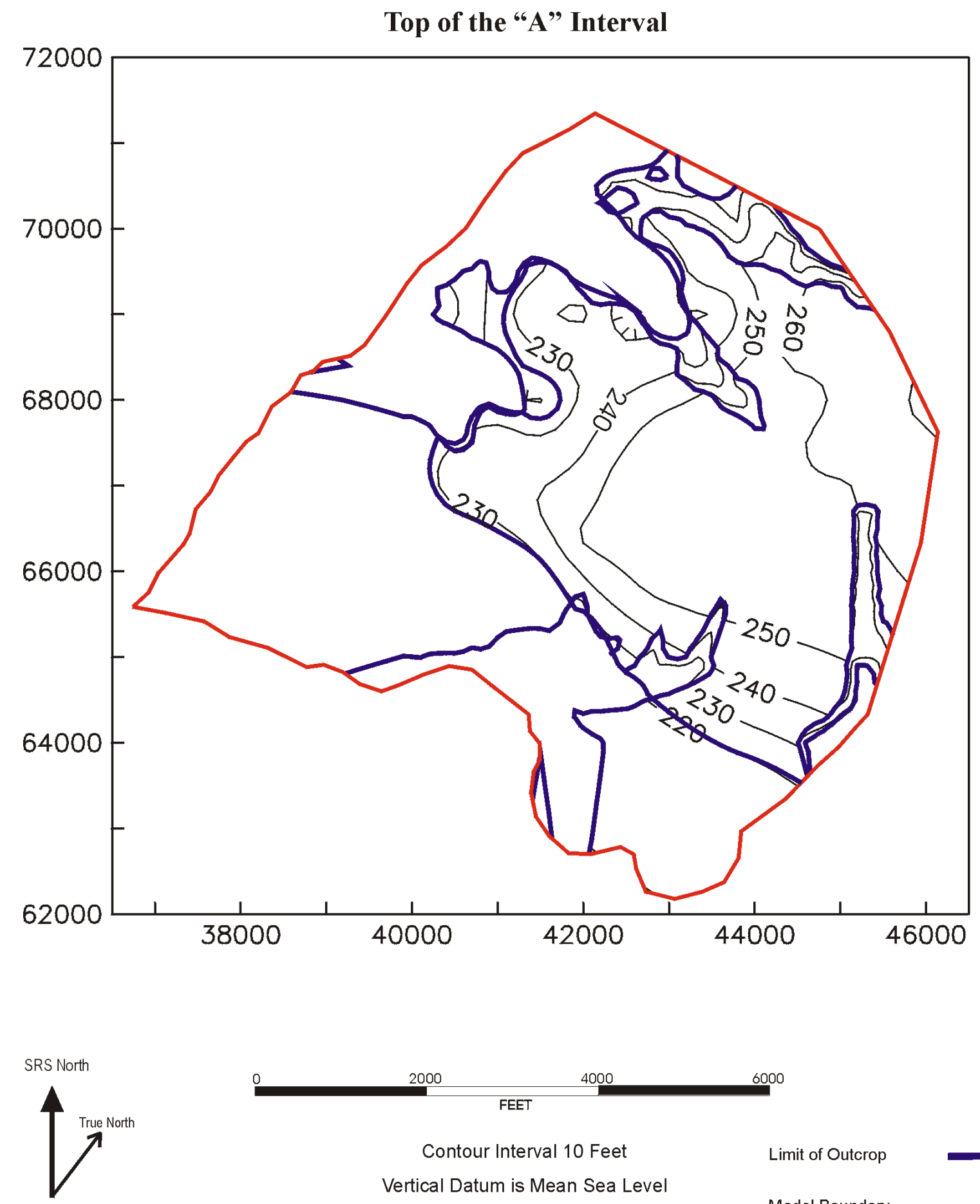

Contour Interval 10 Feet

Limit of Outcrop

Vertical Datum is Mean Sea Level

Model Boundary

Figure 2-26. Altitude-Contour Map of the Top of the "A" Interval 

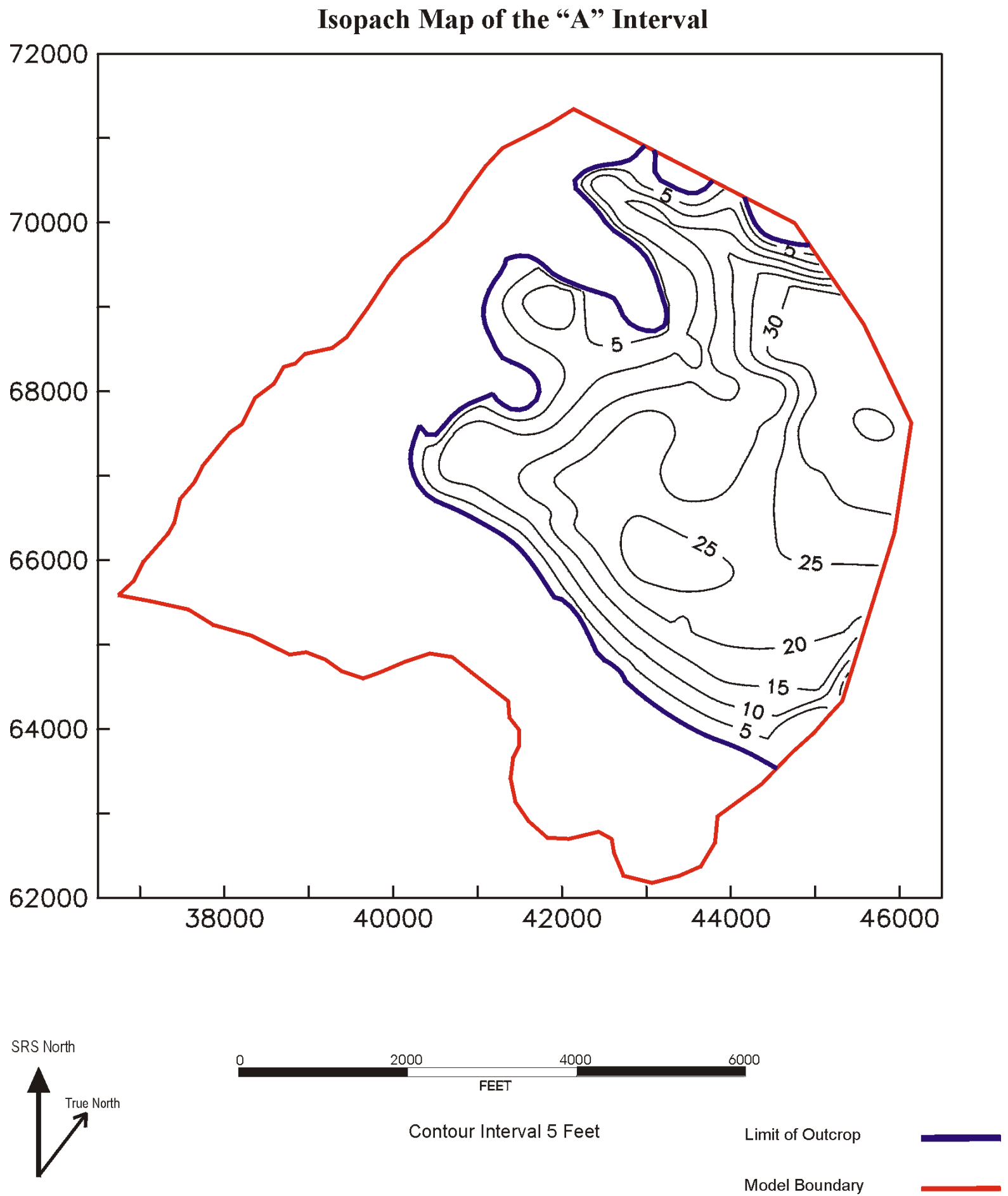

Figure 2-27. Isopach Map of the " $A$ " Interval 

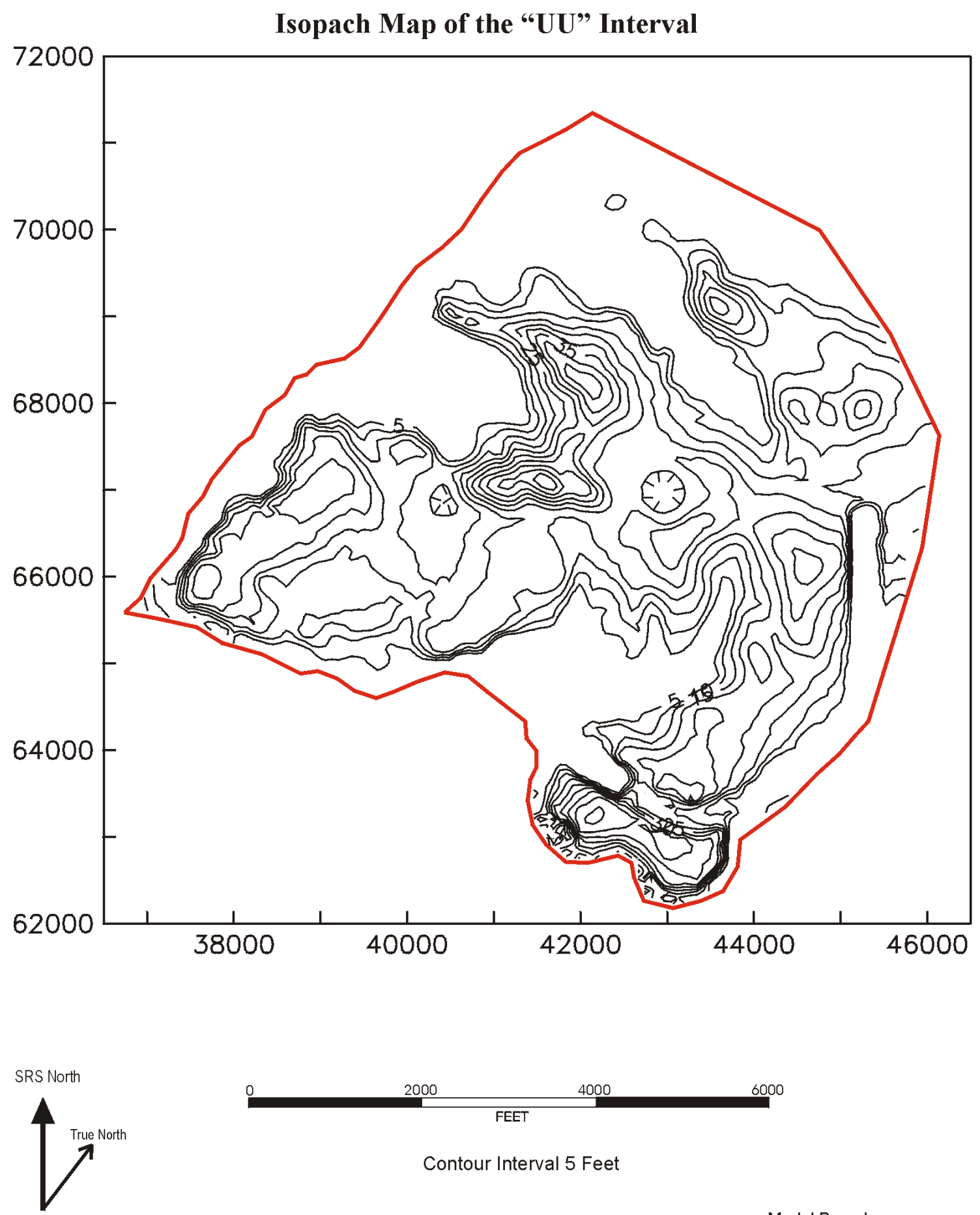

Model Boundary

Figure 2-28. Isopach Map of the "UU" Interval 


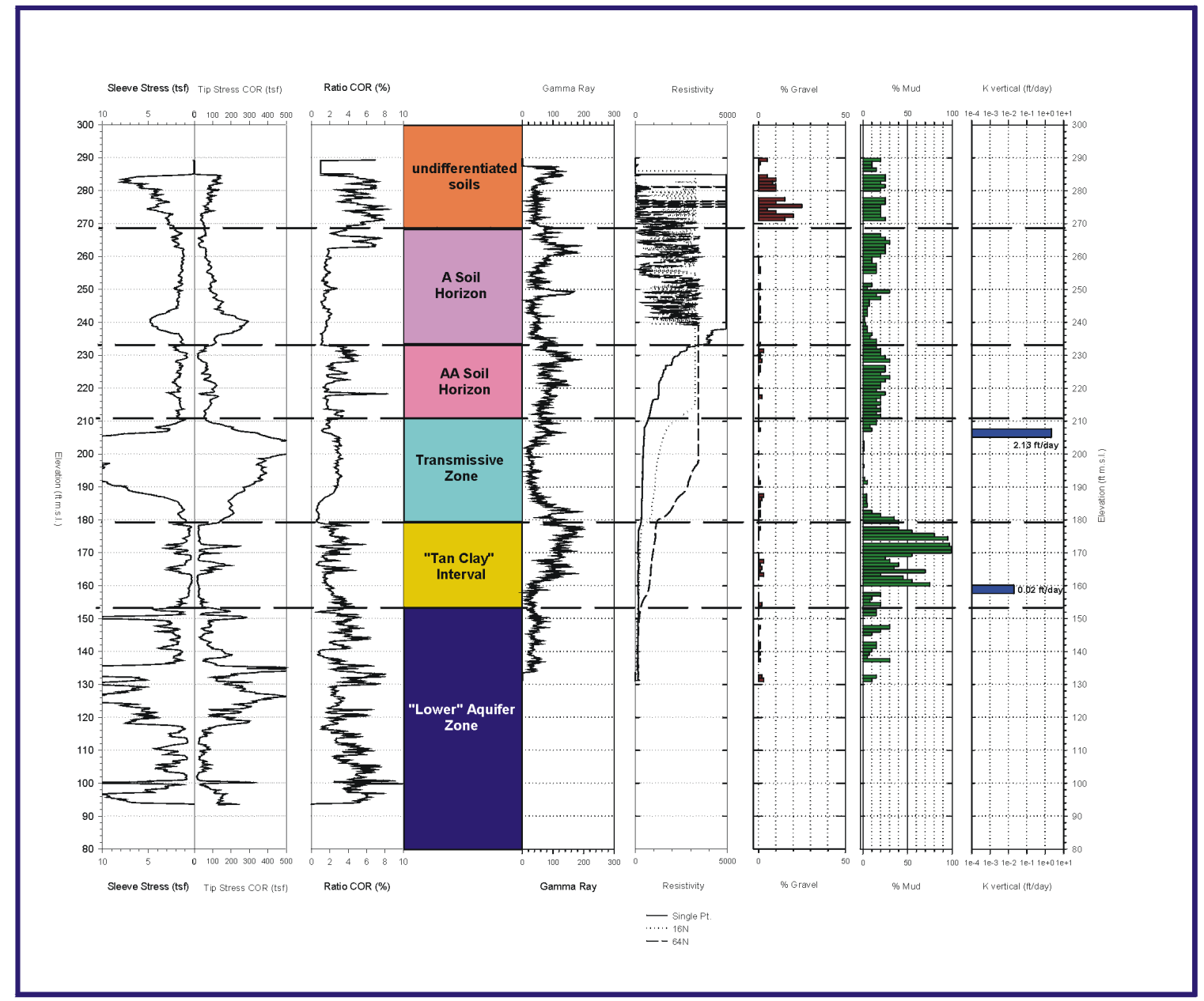




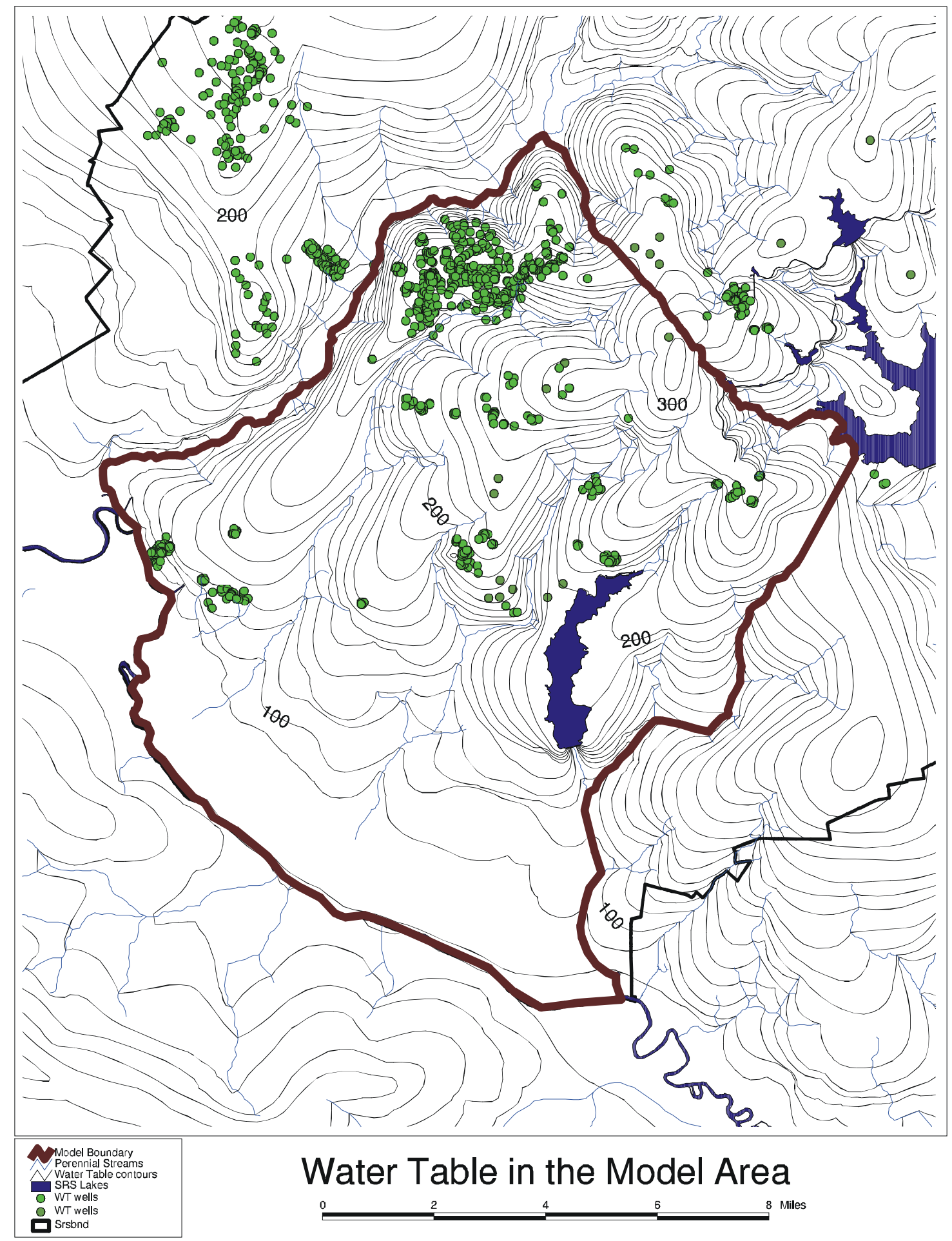

Figure 2-30. Regional Water Table Map 

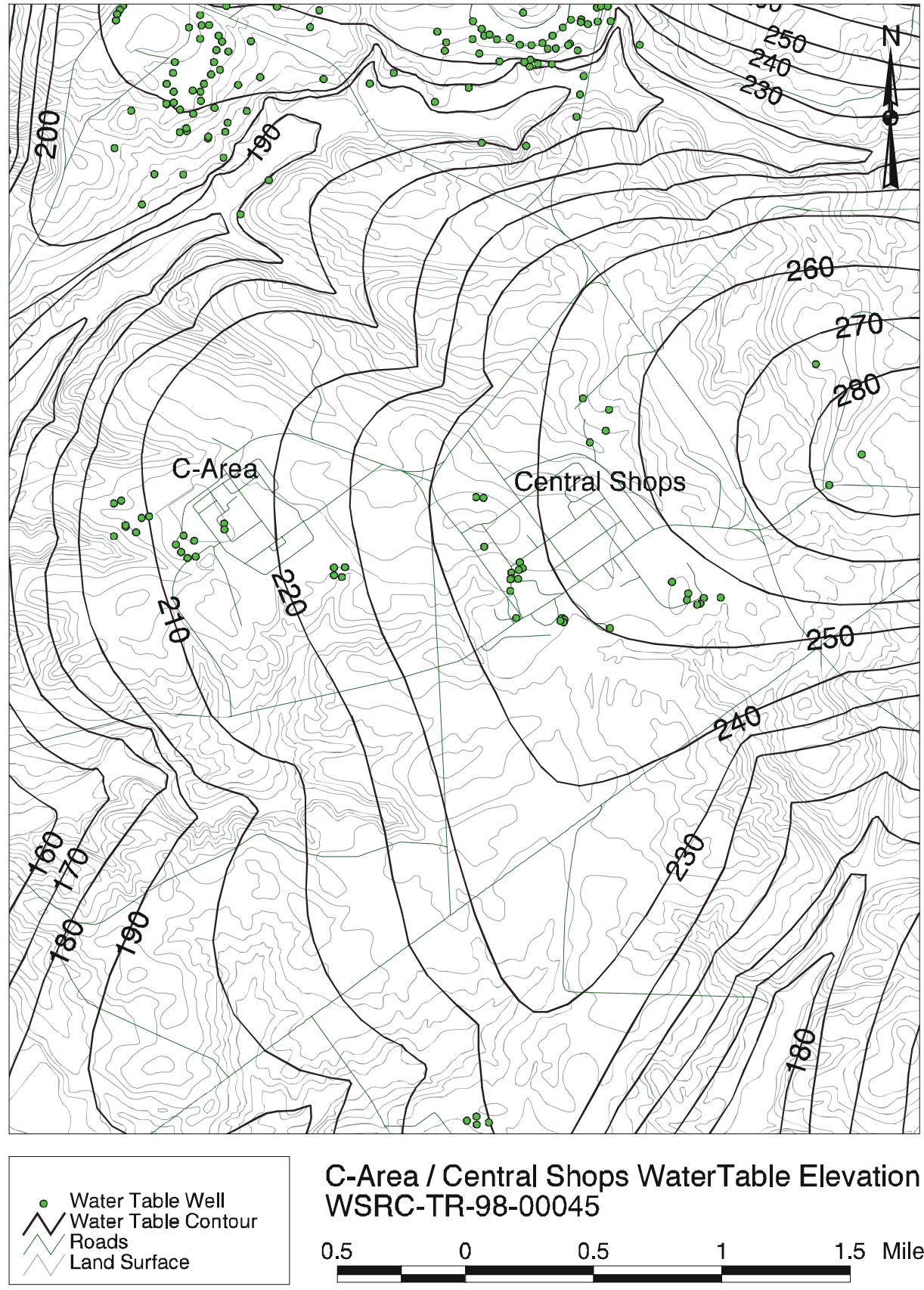

C-Area / Central Shops WaterTable Elevation WSRC-TR-98-00045

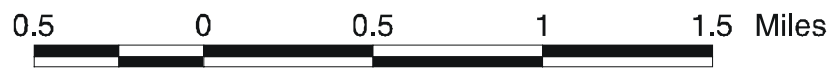

Figure 2-31. Water Table Map for C Reactor Area 


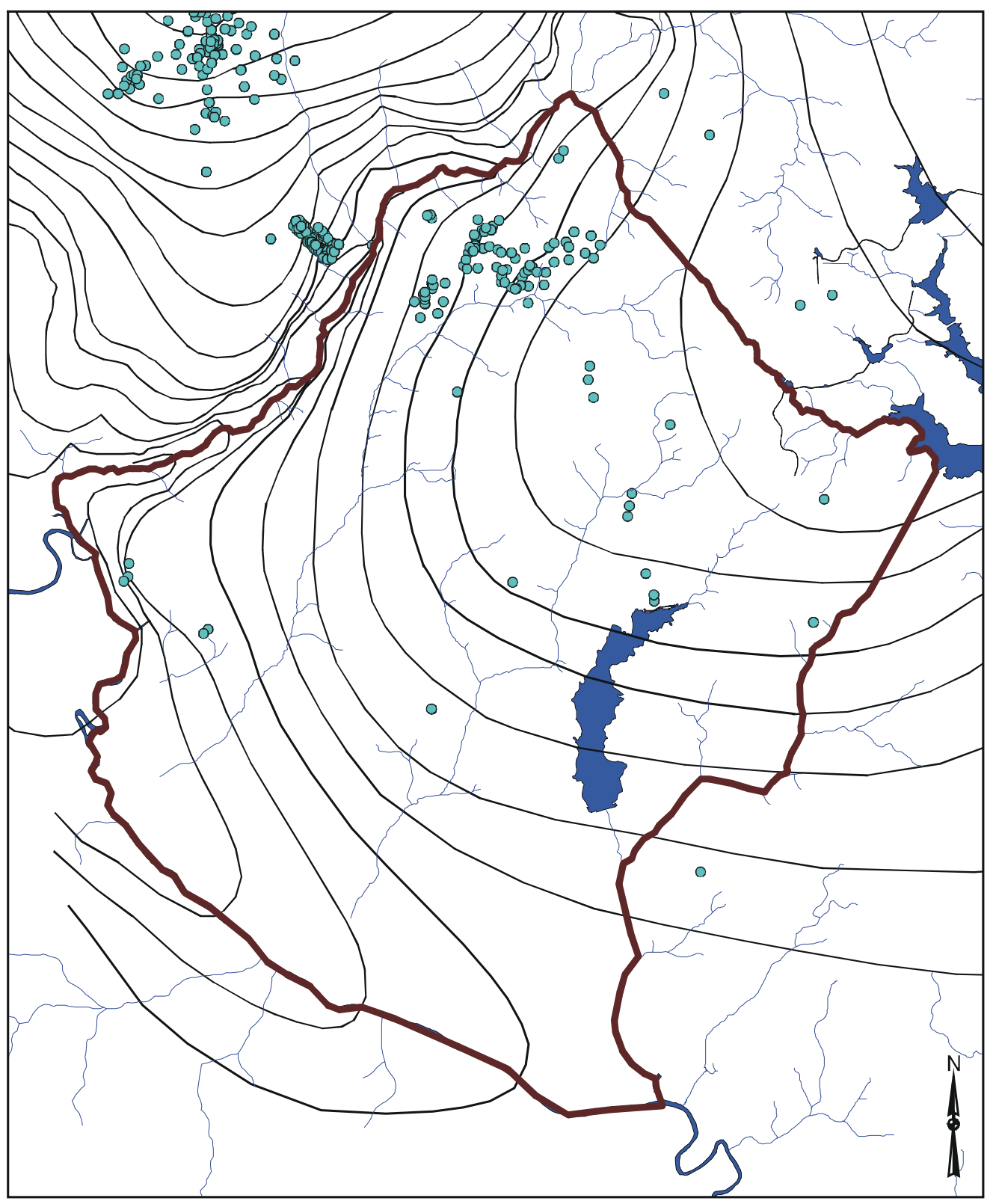

Model Boundary Perennial streams Gordon Aq. Wells Gordon Potentiometric Level in the Model Area SRS Lakes

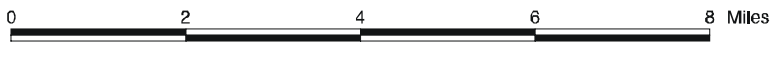

Figure 2-32 Regional Gordon Potentiometric Surface 


\section{Reactor Area (RGW) Piezometers}

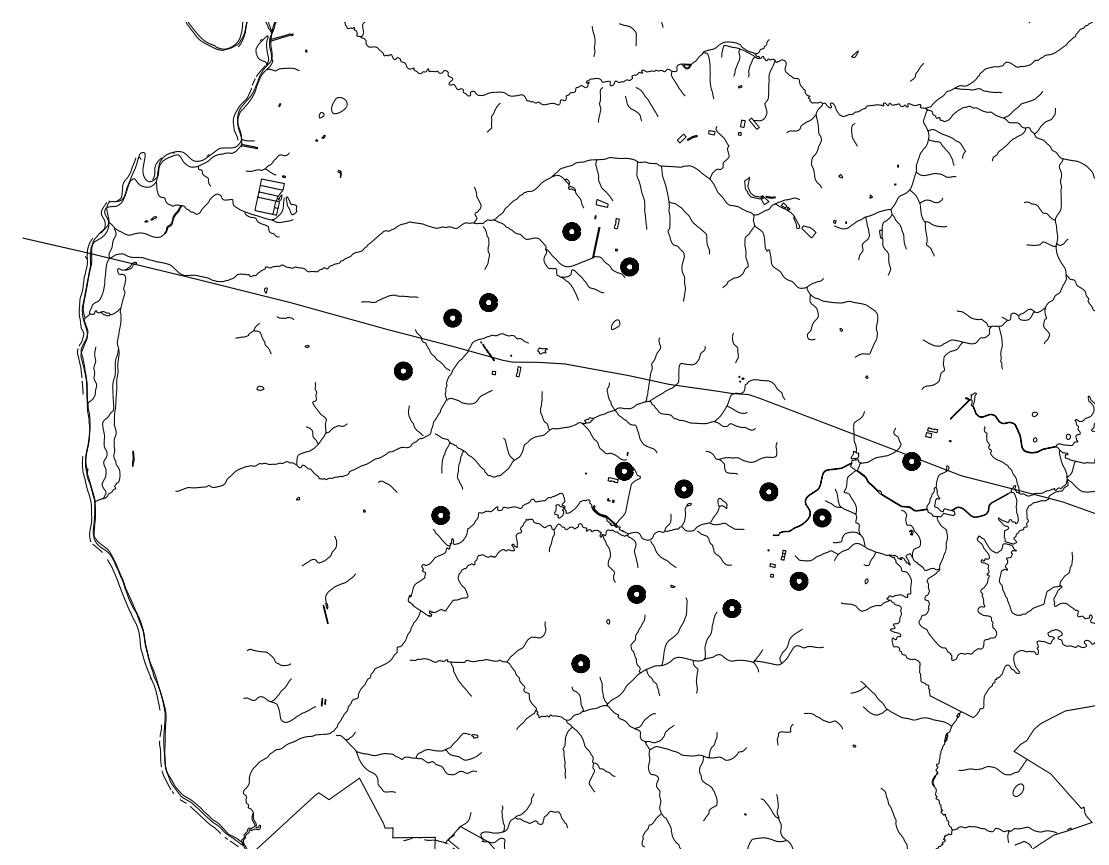

Figure 2-33 Locations of Reactor Area Piezometers Installed in 1998 


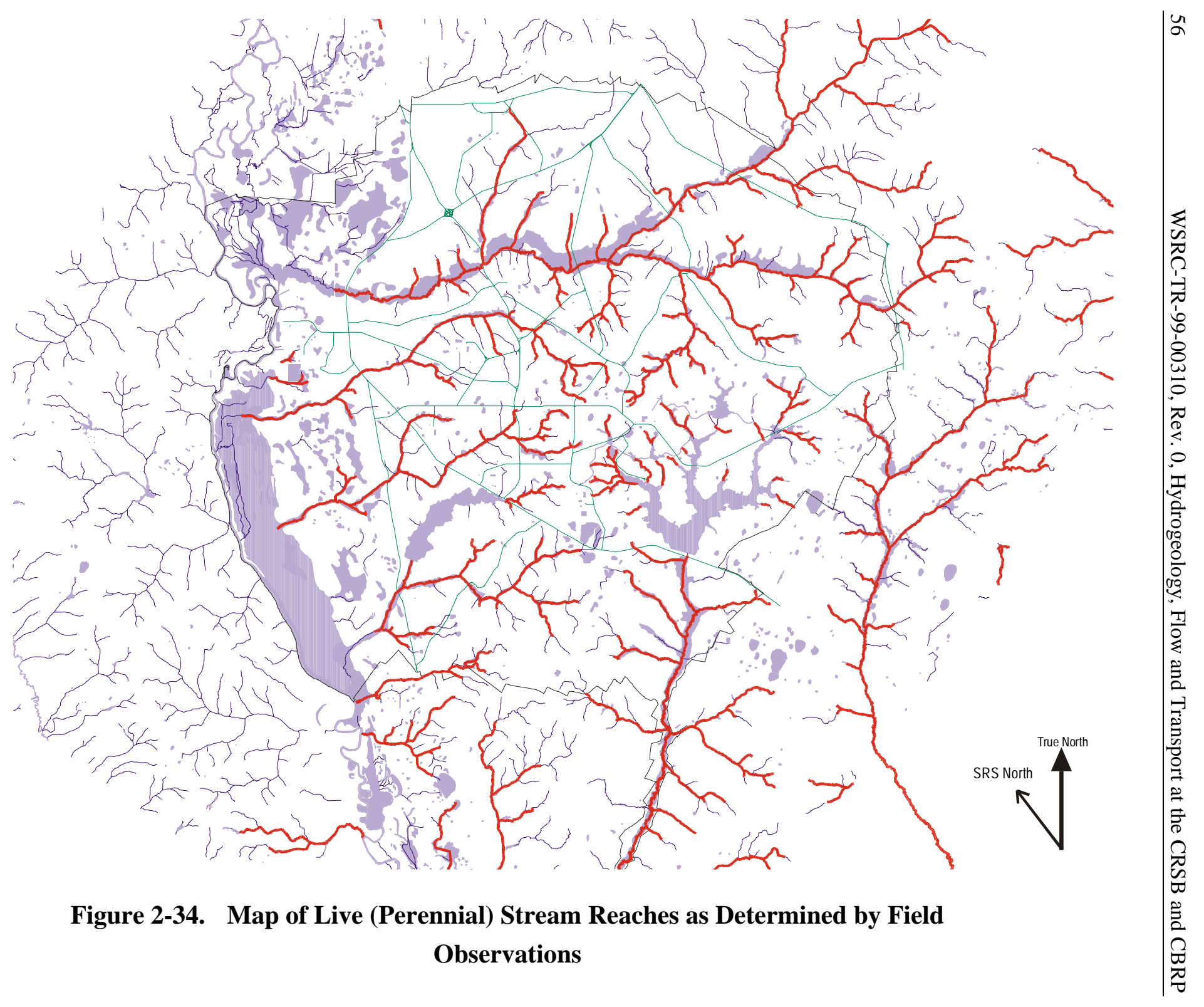




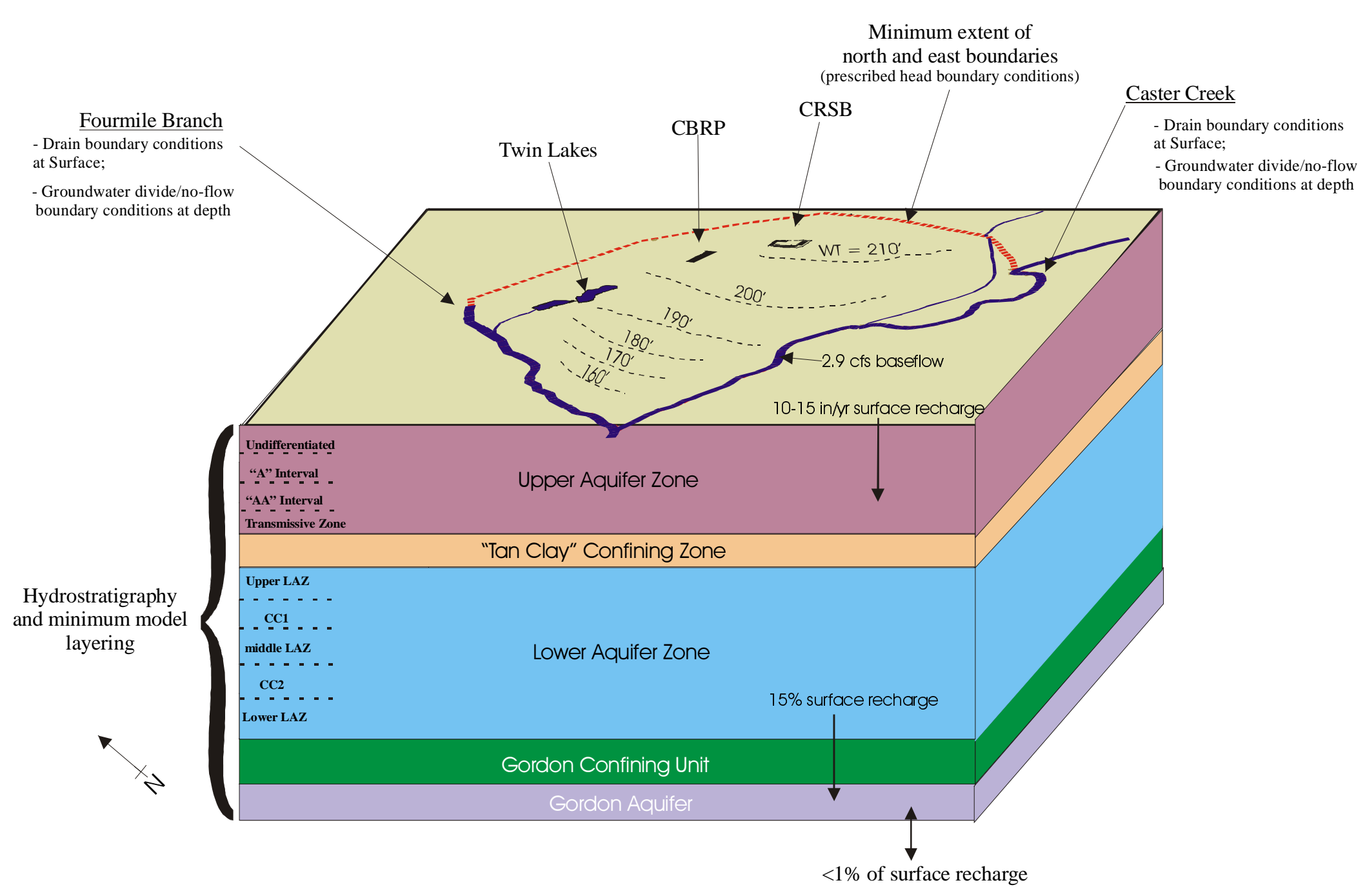

Figure 2-35. Hydrogeologic Conceptual Model 


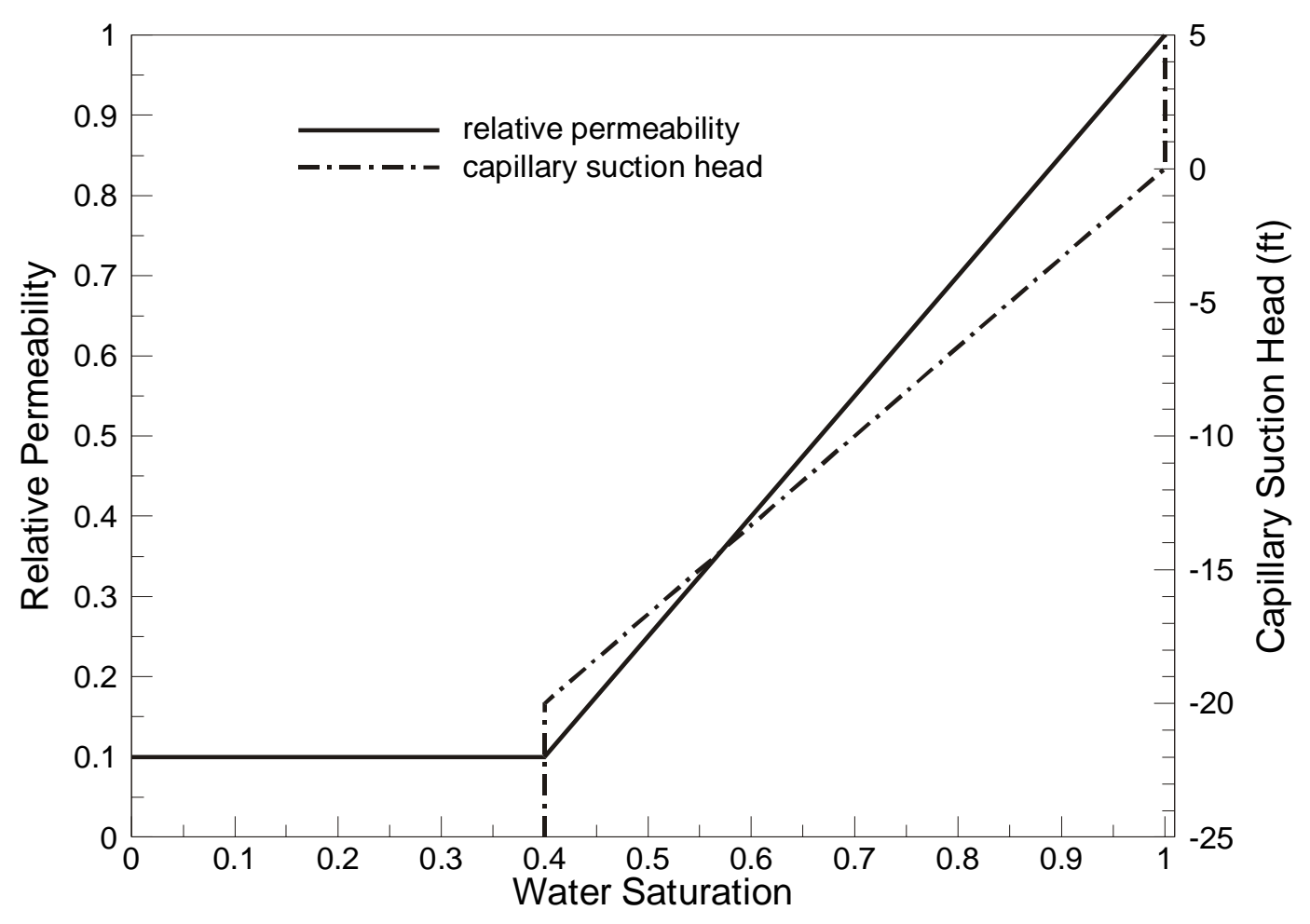

Figure 2-36. Approximate Soil Characteristic Curves 
Table 2-1. Summary of Hydraulic Head Targets

\begin{tabular}{|l|c|c|}
\hline Aquifer unit or zone & Category & Number of hydraulic head targets \\
\hline Gordon & 1 & 2 \\
\hline "lower" UTRA & 2 & 5 \\
\hline transmissive & 3 & 18 \\
\hline AA & 4 & 11 \\
\hline A and uu & 5 & 10 \\
\hline Mixed & 6 & 2 \\
\hline
\end{tabular}


Table 2-2. Base Flow Estimates Based on a Single Field Measurement Under Low Flow Conditions (Appendix E).

\begin{tabular}{|c|c|c|}
\hline Stream reach & $\begin{array}{c}\text { Field measurement } \\
(\mathbf{c f s})\end{array}$ & Date \\
\hline Caster creek & 2.9 & 7 Dec 98 \\
\hline Creek south of Twin Lakes & 0.15 & 8 Dec 98 \\
\hline Twin Lakes creek & 0.19 & 8 Dec 98 \\
\hline Creek north of Twin Lakes & 0.15 & 8 Dec 98 \\
\hline Creek south of Central Shops outfall creek & 0.06 & 9 Dec 98 \\
\hline Central Shops outfall creek & 0.76 & 9 Dec 98 \\
\hline
\end{tabular}




\subsection{C-AREA GROUNDWATER FLOW MODEL DEVELOPMENT}

The process used to transform the hydrogeologic data and conceptual model into a numerical groundwater flow is presented in this section. In general, the C-Area flow model being developed shares the same conceptual model as the regional groundwater flow model developed by Flach and others (1999). Parameters from the calibrated regional model are generally taken as the default setting for the local-scale C-Area model. Examples include hydrostratigraphic picks and surfaces, hydraulic conductivities, leakances, recharge and boundary conditions. For brevity the large-scale flow model of Flach and others (1999) will be referred to as the "regional model".

\subsection{Code Selection and Description}

The Subsurface Flow $\underline{\text { And }} \underline{\text { Contaminant }}$ Transport (FACT) code was selected for numerical flow simulations. FACT is a variably saturated, three-dimensional, finite-element groundwater flow and solute contaminant transport code developed by the Savannah River Technology Center (SRTC) (Hamm and Aleman, 1999). FACT is an outgrowth of the SAFT3D code developed jointly by HydroGeoLogic, Inc. and SRTC (Huyakorn and others, 1991). FACT version 2.0 was selected for the study so that more accurate head and particle tracking solutions could be obtained by replacing the influence coefficient algorithm used in version 1.1 with more accurate Gaussian quadrature available in version 2.0. Other distinguishing features of FACT include efficient memory management and numerical algorithms that make large grids feasible, and user-friendly boundary conditions. For example, the combination recharge/drain boundary condition automatically determines whether a surface node should receive recharge or be discharging groundwater, based on the head solution. The software has been extensively verification and validation (V\&V) tested, and successfully used to model other areas of the SRS. The reader is referred to the FACT User's Manual for a more thorough description of the code (Hamm and Aleman, 1999). FACT was selected primarily because

1) the variably saturated formulation enables explicit modeling of the vadose zone, which may be important for subsequent modeling of contaminant transport or remedial actions using the present model or a derivative

2) the code meets the software Quality Assurance requirements of 1Q, 20-1

3) the authors have a strong working knowledge of the code 
4) existing FACT models and data pre-processing software can be used to support model development

5) the source code is available.

Other codes having similar attributes would also be acceptable.

\subsection{Model Configuration and Mesh}

As described in section 2.5, groundwater recharge over greater C-Area is thought to potentially travel as deep as the Gordon aquifer before leaving the model domain and discharging to the Savannah River, Upper Three Runs, or tributaries. Contamination originating from $\mathrm{C}$-Area is expected to be confined to the Upper Three Runs and Gordon aquifer units. Compared to recharge, groundwater flow across the bottom of the Gordon aquifer is very small. With these considerations, the bottom of the Gordon aquifer is a natural choice for the bottom of the model domain. The contamination sources to be considered are the CRSB and CBRP, which essentially lie at ground surface. Therefore, the top of the model domain is chosen to coincide with the topographic surface. The Upper Three Runs aquifer discharges to Fourmile Branch, and major tributaries such as Caster Creek and the "construction outfall" creek from the Central Shops (Figure 3-1). These streams are natural choices for lateral model boundaries, as drain boundary conditions can be defined from known stream elevations. The southern model boundary spans the headwaters of Caster Creek and the "construction outfall" creek from the Central Shops. Conditions are less certain along the southern boundary, but should have minimal effect on flow and transport at the CRSB and CBRP. Figures 3-1 and 3-2 illustrate the chosen extent of the active C-Area model grid.

The chosen areal grid is 14,600 by $13,200 \mathrm{ft}$ with a resolution of 200 feet (Figure 3-1). The mesh resolution is a compromise between the need to resolve topographic features that drive groundwater flow in the UTR aquifer, and computer memory, run-time, and storage limitations. There are 73 elements along the east-west model coordinate axis and 66 elements along the north-south axis. The vertical resolution varies depending on hydrogeologic unit and stratigraphic variations (Figure 3-2). The top surface of the mesh conforms to the ground surface (Figure 3-3). The bottom surface of the mesh coincides with the bottom of the Gordon aquifer unit. Interior node layers conform to the other stratigraphic surfaces defined in section 2. The transmissive, AA and A/uu horizons within the "upper" UTR aquifer unit are each represented with 3 finite-element layers. The vadose zone is 
included in the model. The "tan clay" confining zone is modeled with a 2 element layers. The "lower" aquifer zone is subdivided into 5 element layers, one each for the "uLAZ", "CC1", "mLAZ", "CC2"and "ILAZ" intervals (Figure 3-2). The Gordon confining and aquifer units each contain 2 element layers, for a total of 20 vertical elements from ground surface to the bottom of the Gordon aquifer. The three-dimensional mesh size is therefore $73 \times 66 \times 20=96,360$ elements or $74 \times 67 \times 21=104,118$ nodes.

\subsection{Boundary Conditions}

The entire top surface of the mesh is assigned a combination recharge/drain boundary condition, except for the area covered by L Lake and Par Pond (Figure 3-4). This FACT code option automatically specifies a recharge boundary condition for nodes with a computed head below ground elevation, and a drain boundary condition for nodes with a computed head above ground surface, which is physically correct. The reader is referred to the FACT code manual for detailed information on how this boundary condition is numerically implemented in FACT (Hamm and Aleman, 1999). Surface drain coefficients are set to 1.0 day $^{-1}$ model wide. The selected drain coefficient is sufficiently large to ensure that computed head will be only slightly greater than ground elevation in discharge areas. Streams and rivers can be represented with the FACT recharge/drain boundary condition, instead of general head or river boundary condition, because they are gaining according to the conceptual model. For gaining surface bodies, the FACT recharge/drain, general head, river, and drain boundaries all function as drains and are equivalent. The maximum local recharge rate is specified as $12.5 \mathrm{in} / \mathrm{yr}$ based on the regional flow model calibration results (i.e. Flach and others, 1999). This value is consistent with the estimated range of 10 to $16 \mathrm{in} / \mathrm{yr}$ for recharge developed in section 2.4.

The entire bottom surface of the mesh is assigned a general head boundary condition to account for flow into or out of the model domain across the Crouch Branch confining unit (Meyers Branch confining system). A leakance coefficient of $3 \times 10^{-6} \mathrm{~d}^{-1}$ is assumed based on Aadland and others (1995, plate 17). This value is the same as that assumed in the regional model. The head distribution in the Crouch Branch aquifer is also taken from Aadland and others (1995, plate 45). The C-04 outfall was shutdown in September, 1996 and is not modeled. Other outfall flows are insignificant.

Boundary nodes between the top and bottom surfaces of the mesh are assigned either a noflow or prescribed head boundary condition. Consistent with the conceptual model, boundary nodes underlying major streams and rivers are assigned no-flow boundary conditions because 
no groundwater is assumed to cross beneath these features. No-flow boundary conditions are also specified in the vadose zone. Where no-flow boundary conditions are inappropriate in the saturated zone, head is prescribed based on the simulated head in the regional flow model. For the Gordon aquifer, the result is no flow conditions on all boundaries as shown in Figure 3-5. For the Upper Three Runs aquifer, head is prescribed along and between the upper reaches of Caster Creek and the "construction outfall" creek (Figure 3-6). Elsewhere, no flow boundary conditions are specified for this unit.

\subsection{Material Properties}

Default hydraulic conductivities are taken from the calibrated regional model. Horizontal conductivity in the Gordon aquifer is set to $35 \mathrm{ft} / \mathrm{day}$, which is consistent with extensive field data from both on and off the Savannah River Site reviewed in section 2.2.2.1 and by Aadland and others (1995). The vertical conductivity of the Gordon confining unit is set to $10^{-4} \mathrm{ft} /$ day in accordance with the regional model and the field data summarized in section 2.2.2.2 and by Aadland and others (1995). Conductivities in the Upper Three Runs aquifer unit are initially set to the values used in the regional model.

Between CRSB and CBRP and downgradient areas along Caster Creek and Fourmile Branch, hydraulic conductivities are subsequently overwritten with initial estimates based on CPT lithologic pushes. The use of CPT measurements to infer conductivity at the model scale is motivated by experience with the regional flow model in C-Area. The regional modeling effort revealed that significant conductivity variations occur between CRSB and Caster Creek. Specifically, the CPTu data indicate that, on the north side of Caster Creek, the tan clay largely disappears as a confining unit and is simultaneously underlain by a deeper confining zone within the "lower" UTRA. The underlying confining zone is interpreted to be a calcareous wackestone/mudstone based on the CPTu signature of low tip and sleeve resistance with high pore pressure. This heterogeneity must be accounted for in a flow model in order to reproduce flow directions deduced from plume data. The CPT conductivity estimates are derived by correlating tip, sleeve and pore pressure measurements to percent fines and hydraulic conductivity. Then the small-scale conductivity estimates are upscaled and interpolated onto the local-scale flow model grid using stochastic theory. The methodology is developed in detail in Appendix G. Figures G-28 through G-59 show the resulting conductivity fields. The predicted conductivity fields provide a starting point for flow model calibration. The predictions are best-estimates, but contain uncertainty due to the $\mathrm{CPTu}$ correlations and upscaling approach. To achieve adequate model calibration, 
modifications will undoubtedly be required to match water level, plume, and other data, in addition to CPTu measurements.

The predicted conductivity fields presented in Figures G-28 through G-59 reveal important spatial trends. Note from Figures G-36 through G-47 that the predicted conductivity of the TZ, TCCZ and uLAZ zones increase abruptly in the vicinity of Caster Creek. Simultaneously, the horizontal (Figure G-34) and vertical (Figure G-35) conductivity of the underlying $\mathrm{CC} 1$ zone decreases abruptly. Hence, the $\mathrm{CPTu}$ predictions indicate that, on the north side of Caster Creek, the tan clay largely disappears as a confining unit and is simultaneously underlain by a deeper, more significant confining zone within the "lower" UTRA, namely the $\mathrm{CC} 1$ interval. The underlying confining zone is interpreted to be a calcareous wackestone/mudstone based on the CPTu signature of low tip and sleeve resistance with high pore pressure. The highest conductivities in the TZ, TCCZ and uLAZ zones near Caster Creek appear to occur midway between the $\mathrm{C}-04$ outfall and Fourmile Branch.

The approximate soil characteristic curves shown in Figure 2-19 are adopted for the numerical model. An effective porosity value of $25 \%$ is assumed for the purpose of computing a pore velocity field that may be used later for particle tracing. The assumed porosity value is consistent with the general recommendation of Looney and others (1987, p. 39). The value does not affect the steady-state head and Darcy velocity solutions, but will affect subsequent transport simulations. For specific storage a nominal value of $10^{-4} \mathrm{ft}^{-1}$ is input to the FACT code, and would only be important for transient flow simulations within a confined aquifer.

\subsection{Calibration Process}

Groundwater recharge and discharge estimates, monitoring well water level data, hydraulic conductivity estimates based on CPT, the regional modeling effort, and TCE and tritium plume data from CRSB and CBRP were used as targets for calibrating the flow model. The main parameters selected for calibration adjustment are horizontal conductivity in UTR aquifer zones and vertical conductivity in confining zones, because the model is sensitive to these parameters, and each has significant uncertainty. Other input parameters have less impact on the steady-state flow results and/or lower uncertainty, and were set to a value consistent with the regional model throughout calibration. For example, horizontal conductivity in the Gordon aquifer is relatively well known from extensive field-scale tests conducted both on and off the Savannah River Site. Therefore, the horizontal conductivity of 
the Gordon aquifer can be set to $35 \mathrm{ft} /$ day, and essentially held fixed during model calibration.

The overall calibration procedure involves satisfying the following criteria, which are listed in order of priority:

1) Match groundwater flow directions inferred from TCE and tritium plumes migrating from the CRSB and CBRP (Appendix G, Figures G-1 and G-2)

2) Maintain consistency with regional model (Flach and others, 1999)

3) Match simulated heads with water levels measured in monitoring wells (Appendix F)

4) Match base flow estimates for Fourmile Branch tributaries, particularly the larger ones (e.g. Caster Creek) (Table 2-3)

5) Maintain consistency with initial conductivity estimates based on CPT measurements (Appendix G)

Recharge, leakance across the Crouch Branch confining unit, and boundary conditions were held fixed during model calibration. Horizontal and vertical conductivities above the Gordon confining unit were adjusted to achieve model calibration.

The goal of the calibration process is to achieve as good of agreement with prior targets as possible, without resorting to unjustifiable zonal variation in conductivity or other parameters. A lower estimate for achievable calibration accuracy is the uncertainty level in the target data. That is, one should not expect to match calibration targets better than the "noise" level in the data. As discussed in section 2.3.3, head targets that are a result of time averaging have a "2-sigma" uncertainty less than or equal to $3 \mathrm{ft}$, with most being well below $3 \mathrm{ft}$ (Appendix F). However, there are also a significant number of one-time head readings that have much larger uncertainty, typically $\pm 5 \mathrm{ft}$, that inflate average uncertainty. The recharge targets have an uncertainty of roughly $\pm 25 \%$ (section 2.4). Uncertainty was not estimated for stream base targets. Previous models covering portions of the SRS have generally achieved a root-mean-square head residual of $3 \mathrm{ft}$ or so (e.g. Camp Dresser \& McKee, 1989; GeoTrans, 1992; Flach and Harris, 1997), which is a reasonable calibration goal. A reasonable calibration goal for the largest head residual is sometimes defined as 5$10 \%$ of the total head variation in the modeled system. For the Gordon aquifer, the total variation is about $40 \mathrm{ft}$ (Figure 2-16) suggesting a calibration goal of 2 to $4 \mathrm{ft}$ for the 
maximum residual. For the Upper Three Runs aquifer, the total variation is about $120 \mathrm{ft}$ (Figure 2-14) for a calibration goal of 6 to $12 \mathrm{ft}$ for the maximum residual. 


\section{Active Mesh Elements of C Area Groundwater Flow Model}

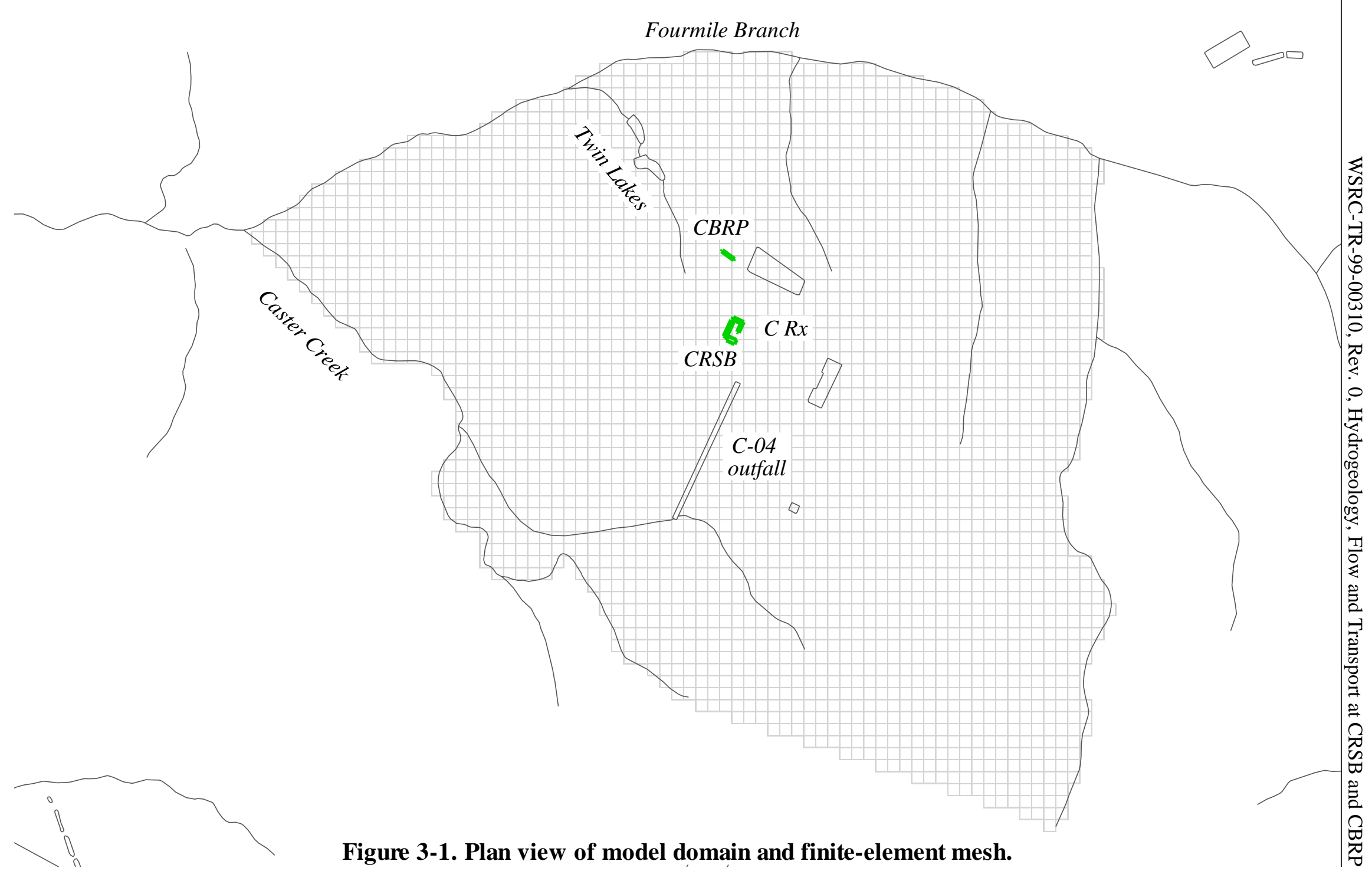


Figure 3-2. North-south cross-sectional slice through mesh at CRSB. 


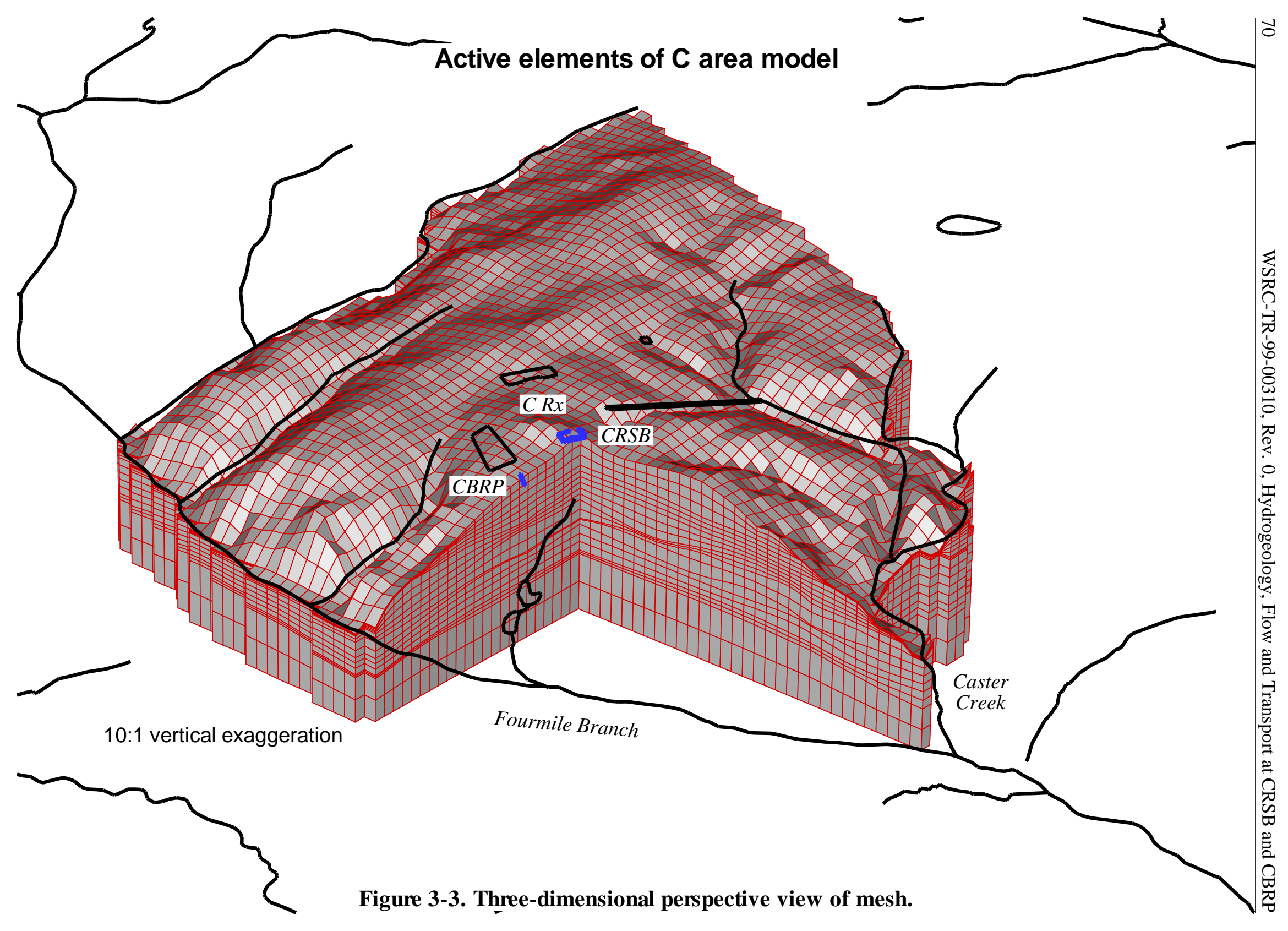




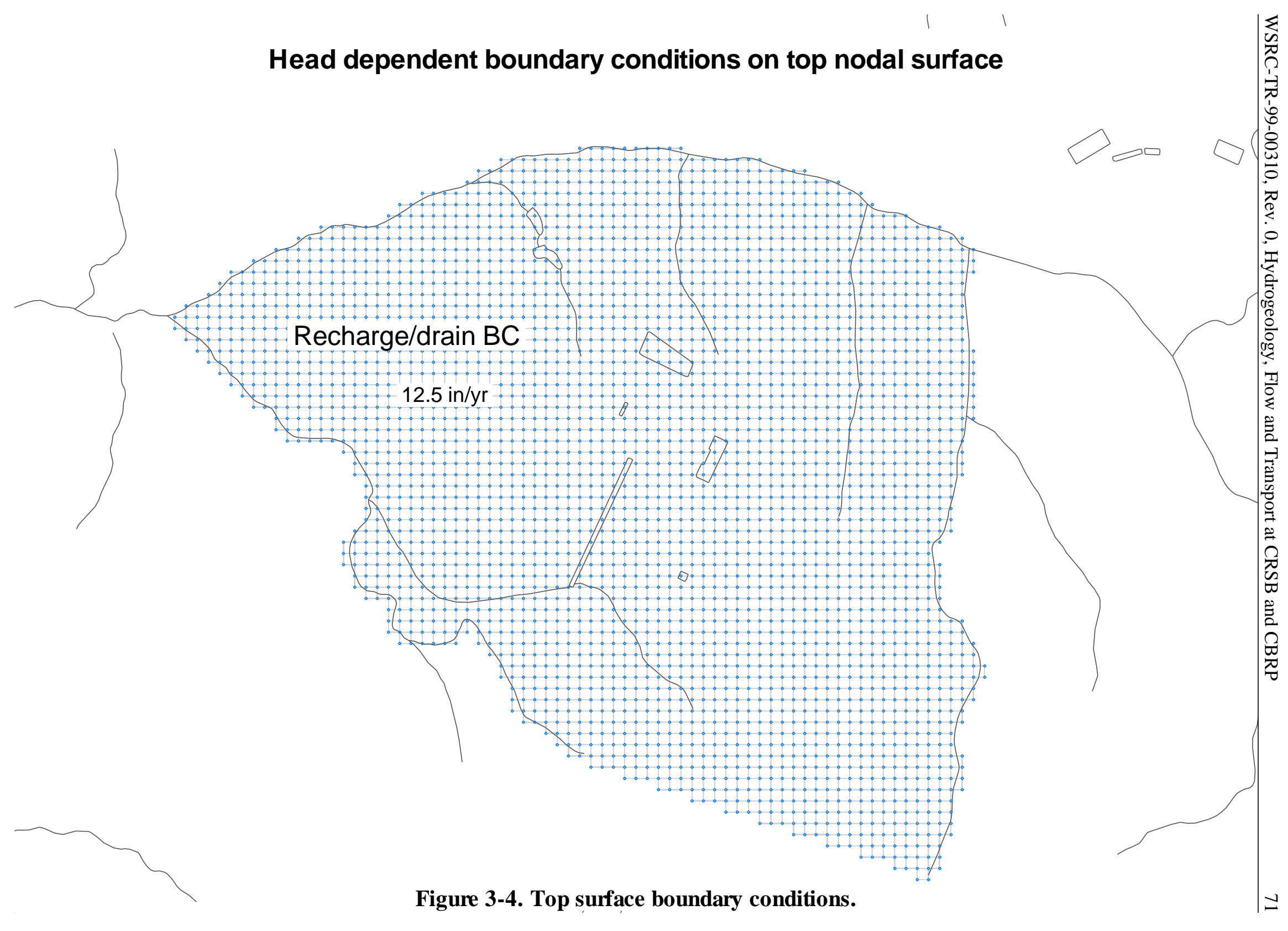




\section{Gordon aquifer boundary conditions}

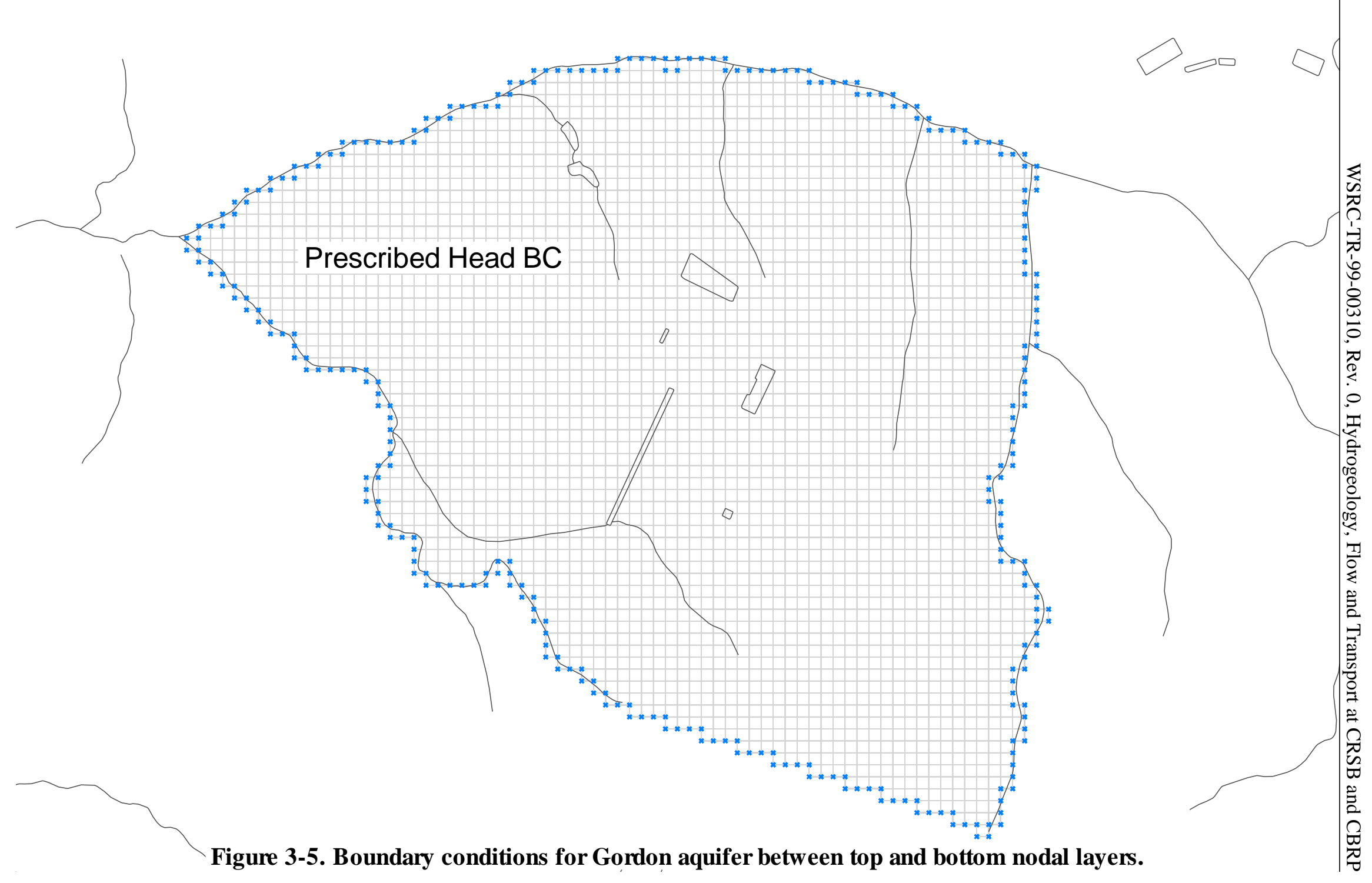




\section{Upper Three Runs aquifer boundary conditions}

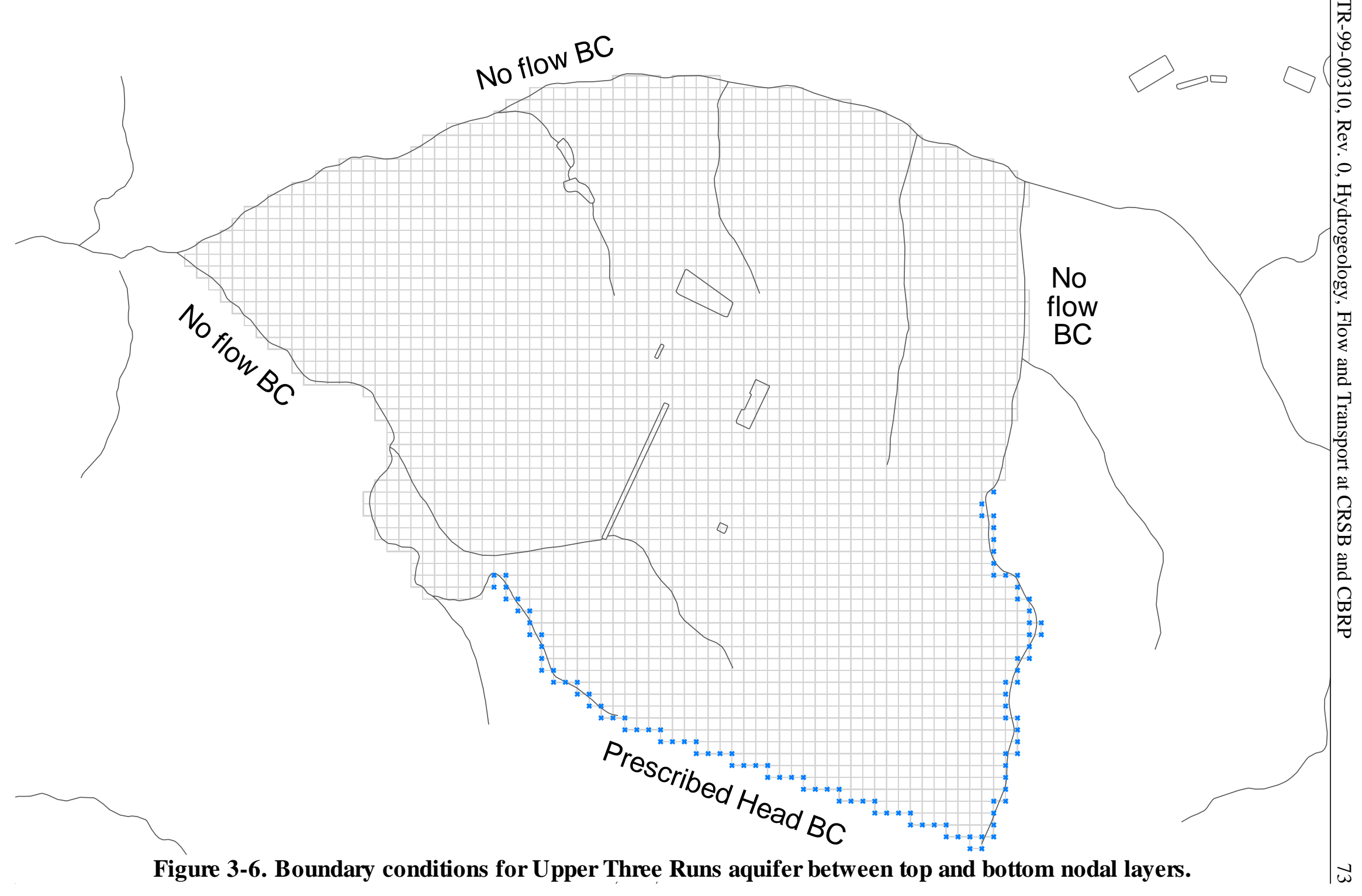




\subsection{C-AREA GROUNDWATER FLOW MODEL RESULTS}

\subsection{Calibration Results}

Table 4-1 summarizes the calibration results for groundwater flow targets. The maximum rate of local recharge is set to $12.5 \mathrm{in} / \mathrm{yr}$ in the FACT recharge/drain boundary condition. The modeled rate is $17 \%$ lower than the prior estimate of $15 \mathrm{in} / \mathrm{yr}$, but very close to the midpoint of the uncertainty range (13 in/yr). Based on total area, which includes seepage areas, the average recharge rate is $11.6 \mathrm{in} / \mathrm{yr}$. Excellent agreement is observed for Caster Creek and a creek receiving outfall from Central Shops, the most significant base flow targets. Predicted base flow for smaller drainages is generally within $0.1 \mathrm{cfs}$.

Table 4-2 summarizes the calibration results for hydraulic head targets. Figure 4-1 graphically compares simulated head with measured head for each aquifer zone. Figures 4-2 through 4-6 illustrate the spatial distribution of head residuals. Appendix F contains a detailed listing of head residual information. The root-mean-square residual is $3.34 \mathrm{ft}$, which is acceptable compared to the r.m.s. calibration goal of $3 \mathrm{ft}$. The mean-absolute residual, which gives lower weight to outliers, is $2.4 \mathrm{ft}$ and well within the calibration goal. The residuals are biased low, except in the " $\mathrm{A} / \mathrm{uu}$ " horizons. The bias is significant in the Gordon and "lower" UTRA and insignificant in the "upper" UTRA. The largest residuals occur in the "lower" UTRA, and are acceptable compared to the calibration goals for maximum residual.

Table 4-3 summarizes the calibration results for hydraulic conductivity. Figures 4-7 through 4-26 show variation in horizontal and vertical conductivity for each model layer in plan view. The calibrated values within the CPT data region are similar to the model-wide averages, which are consistent with the regional model. The calibrated values are consistent with field data (Section 2.2) and previous groundwater flow models (e.g. HSI GeoTrans, 1998, Figure 4-6; HydroGeoLogic, 1998, Table 6.5; Flach, 1998, Table 4; Flach and Harris, 1997; GeoTrans, 1993, Table 4.1; GeoTrans, 1992, Table 3.6; Camp Dresser \& McKee, 1989, Table 3-3). The calibrated conductivity field compares favorably with slug test results for CSB-8D and CSB-9D located near the CSRB, as discussed in Appendix G. The "tan clay" and transmissive zone horizontal conductivities are significantly higher than usual however.

\subsection{Nominal Simulation}

Figures 4-27 through 4-29 illustrate simulated hydraulic head averaged over the entire thickness of the Gordon aquifer and "lower" and "upper" UTR aquifer zones. Simulated head in the aquifer zone containing the water table is shown in Figure 4-30, and Figure 4-31 
illustrates simulated water table elevation. For comparison to Figure 4-27, see Figure 2-16 which shows the Gordon potentiometric surface as based on measured water levels. The estimated water table based directly on head data is shown in Figure 2-14, and can be compared to Figures 4-29 through 4-31. Figures 4-32 through 4-34 illustrate flow directions that are vertically averaged over the entire thickness of the aquifer zones. Figure 4-35 shows simulated seepage faces, and Figure 4-36 illustrates rates of recharge and discharge. Figures 4-35 and 4-36 can be compared to Figure 2-18, which is based on field observations. Example particle tracing results are shown in Figure 4-37 and 4-38 for CRSB and CBRP respectively. These figures may be compared to the observed TCE and tritium migration shown in Appendix G, Figures G-1 and G-2. The particle tracking results are in excellent agreement. A water balance for the model is depicted in Figure 4-39.

\subsection{Model uncertainties and limitations}

Uncertainty in the calibrated flow model can be explored by varying input parameters within their uncertainty range, and in a correlated manner such that agreement with calibration targets is preserved as much as possible. Large scale groundwater flow patterns are most sensitive to surface recharge, which drives overall groundwater flow in this system, and Gordon confining unit (GCU) vertical conductivity, which controls recharge to the Gordon aquifer (equal to leakance from the Upper Three Runs aquifer). Both of these input parameters have significant uncertainty. Uncertainty in $\mathrm{C}$-area groundwater flow paths due to uncertainty in recharge and GCU leakance has been investigated for the regional flow model from which the current C-Area model is developed. The results are presented in Appendix $\mathrm{H}$ and summarized in Table 4-5 of Flach and others (1999). Similar results can be expected for the present model with respect to large scale groundwater movement.

Within the Upper Three Runs aquifer, CPT characterization data and model calibration indicate that hydraulic conductivity varies greatly within the CBRP and CRSB plumes area. This natural heterogeneity strongly affects contaminant migration and plume predictions. Model estimates of this variation are uncertain because the cone penetration testing did not produce direct, field-scale measurements of conductivity. Rather, small-scale conductivity variations were indirectly inferred from tip resistance, sleeve resistance and pore pressure data. Furthermore, the small-scale data were upscaled to the model mesh using stochastic theory which involves a number of assumptions. Uncertainty in portions of the CPT predictions are quantified in Appendix G (e.g. Table G-3, Figure G-9, Figure G-10). Overall uncertainty is explored through comparison to the available field-scale data, namely, slug tests at CSB-8D and CSB-9D. The comparison is summarized in Tables G-6 through G-8 in 
Appendix G. The available field-scale data are insufficient to quantitatively estimate uncertainty in the CPT predictions for $\mathrm{K}_{\mathrm{h}}$, and preclude a formal uncertainty analysis. However, the use of CPT data should reduce model uncertainty compared to ignoring this information. 

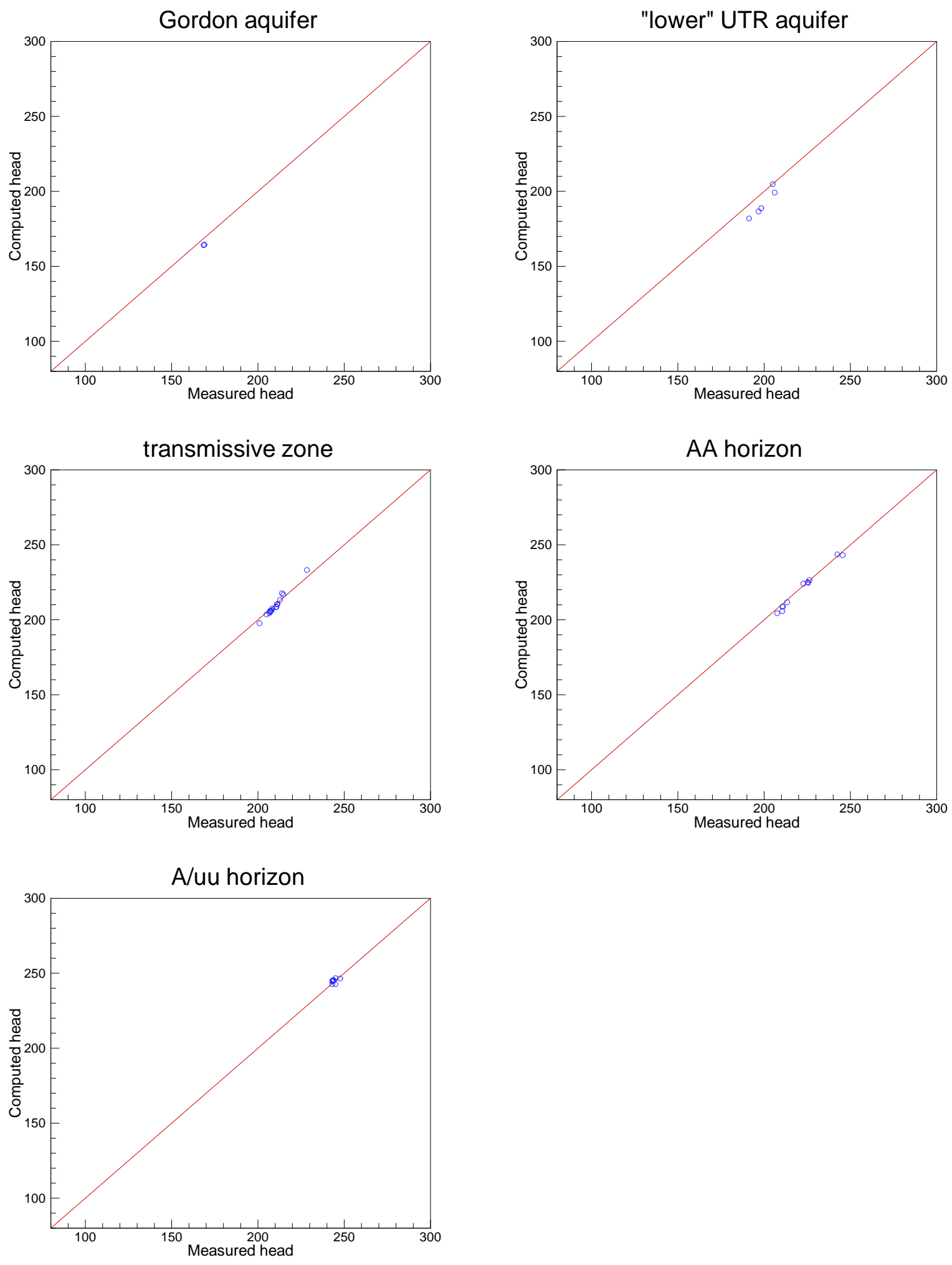

Figure 4-1. Simulated versus measured head for each aquifer zone. 


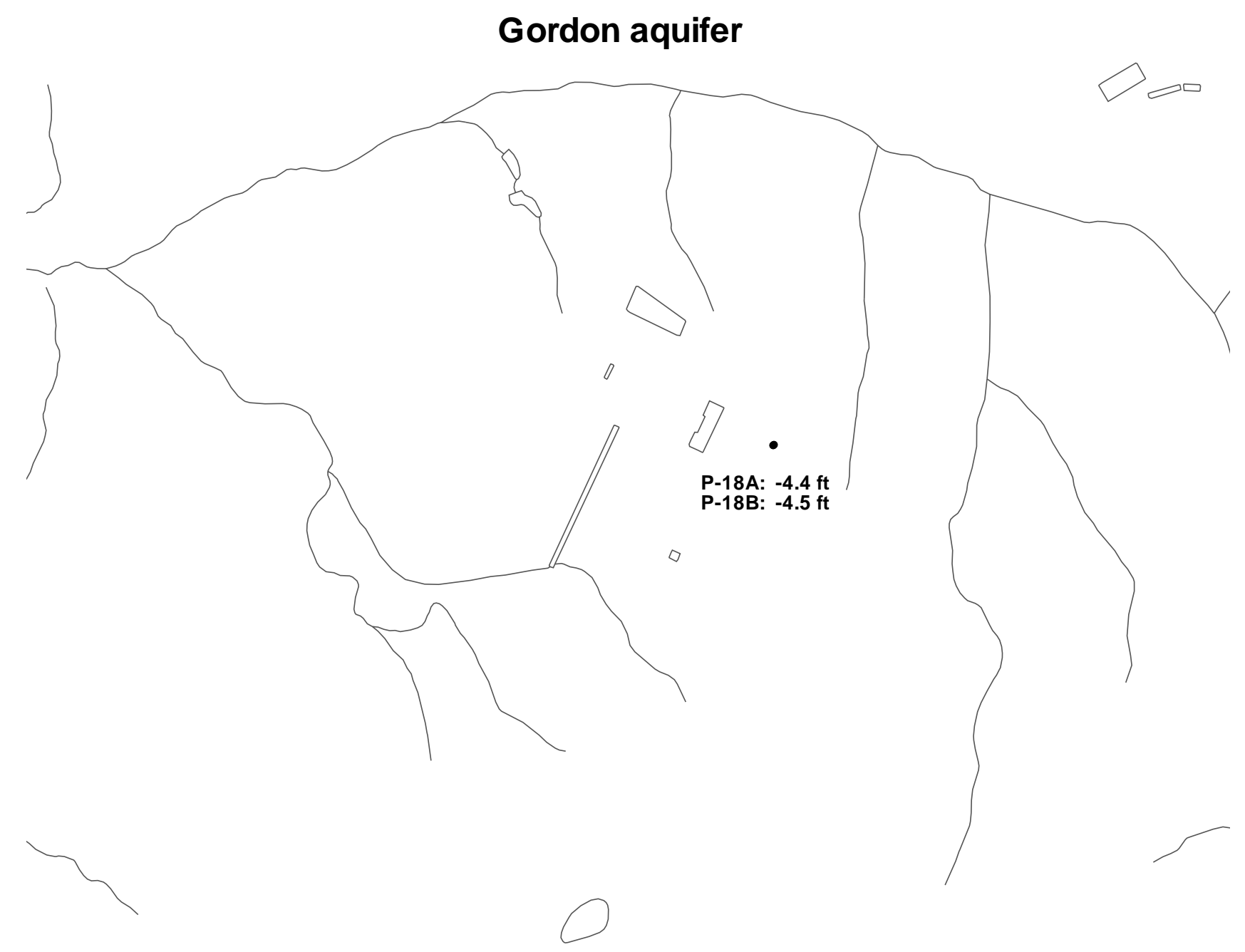

Figure 4-2. Head residuals in the Gordon aquifer. 


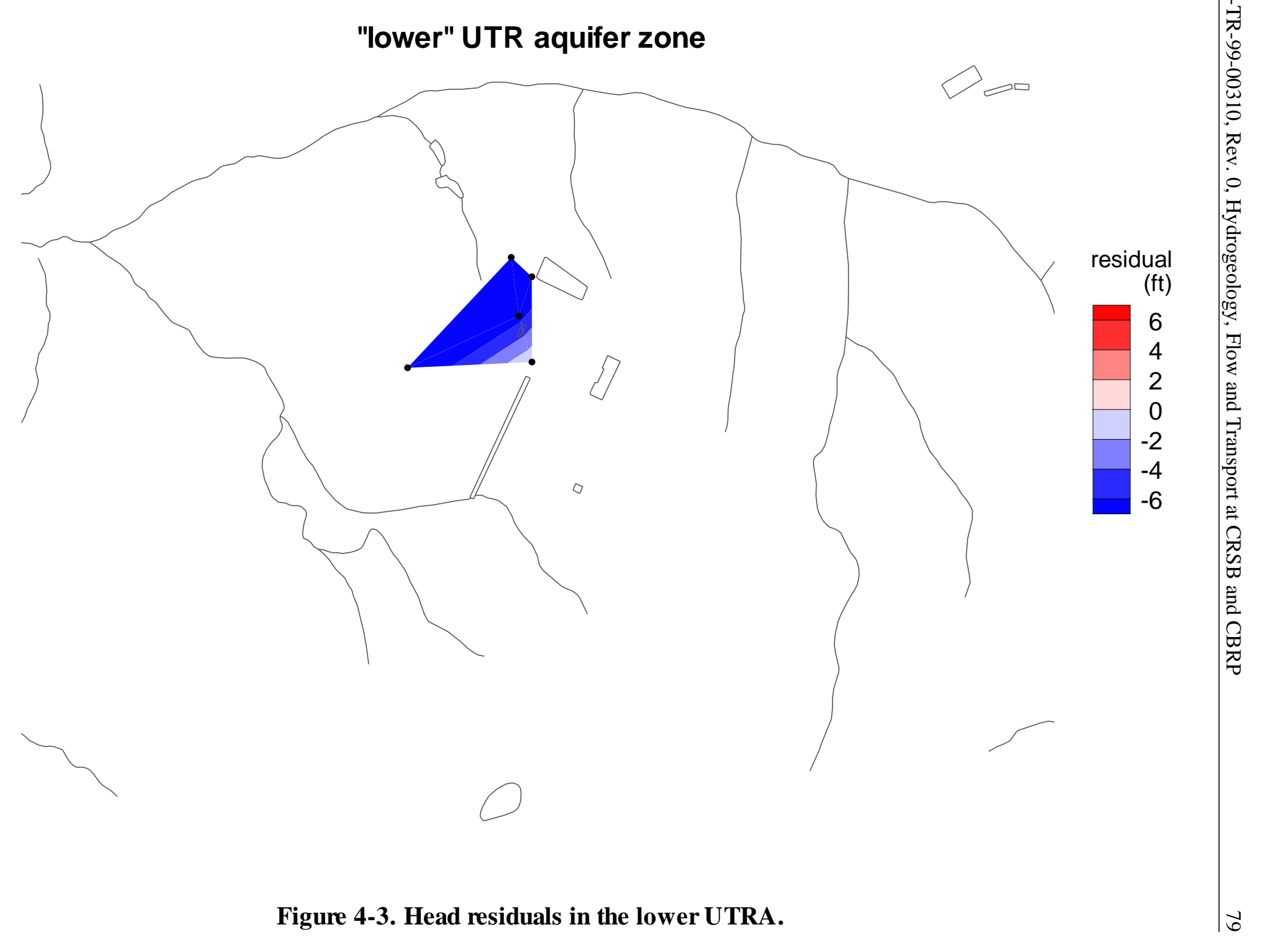




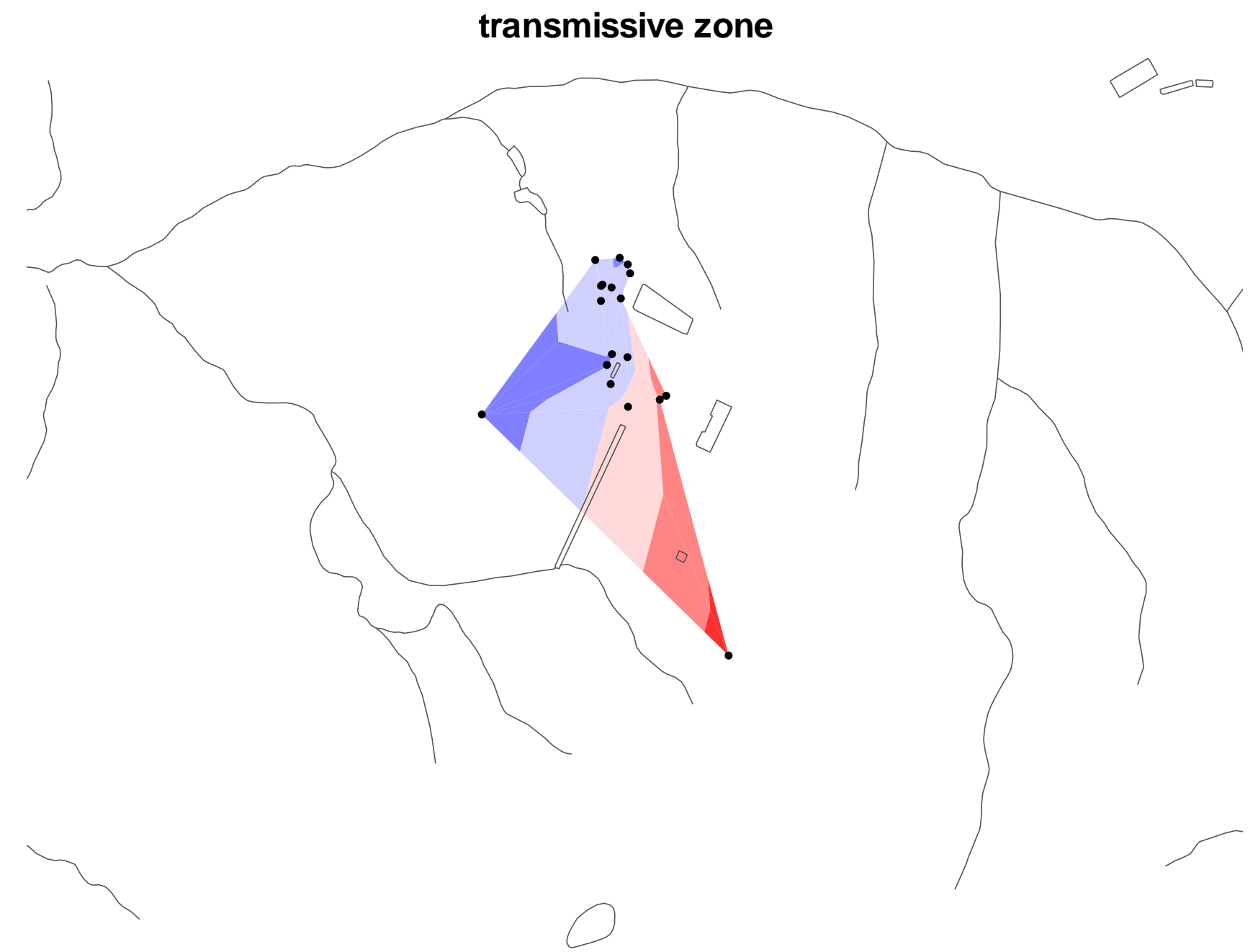

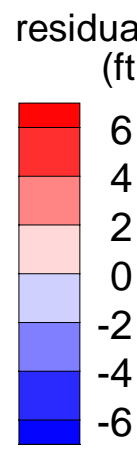

Figure 4-4. Head residuals in the transmissive zone. 


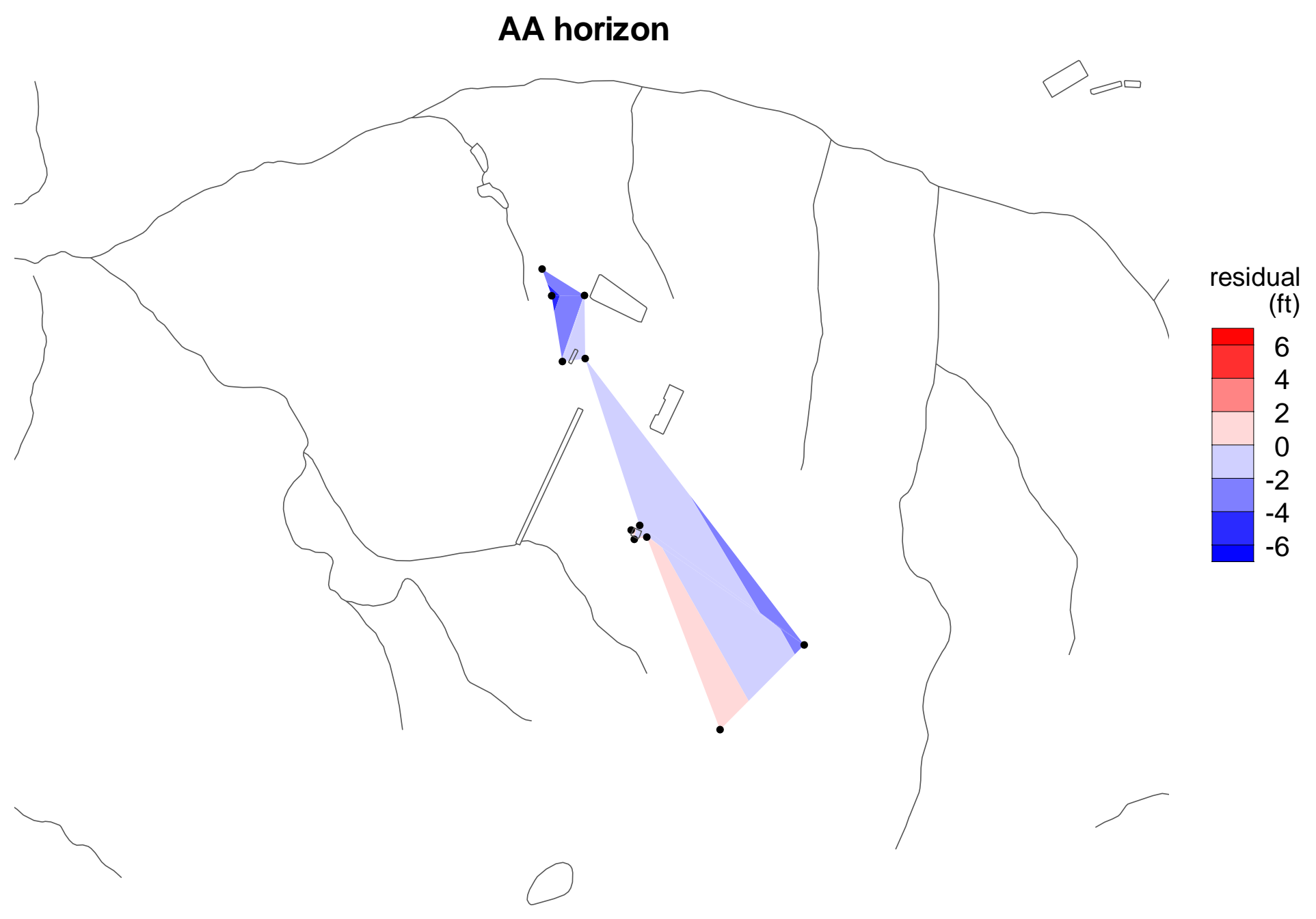




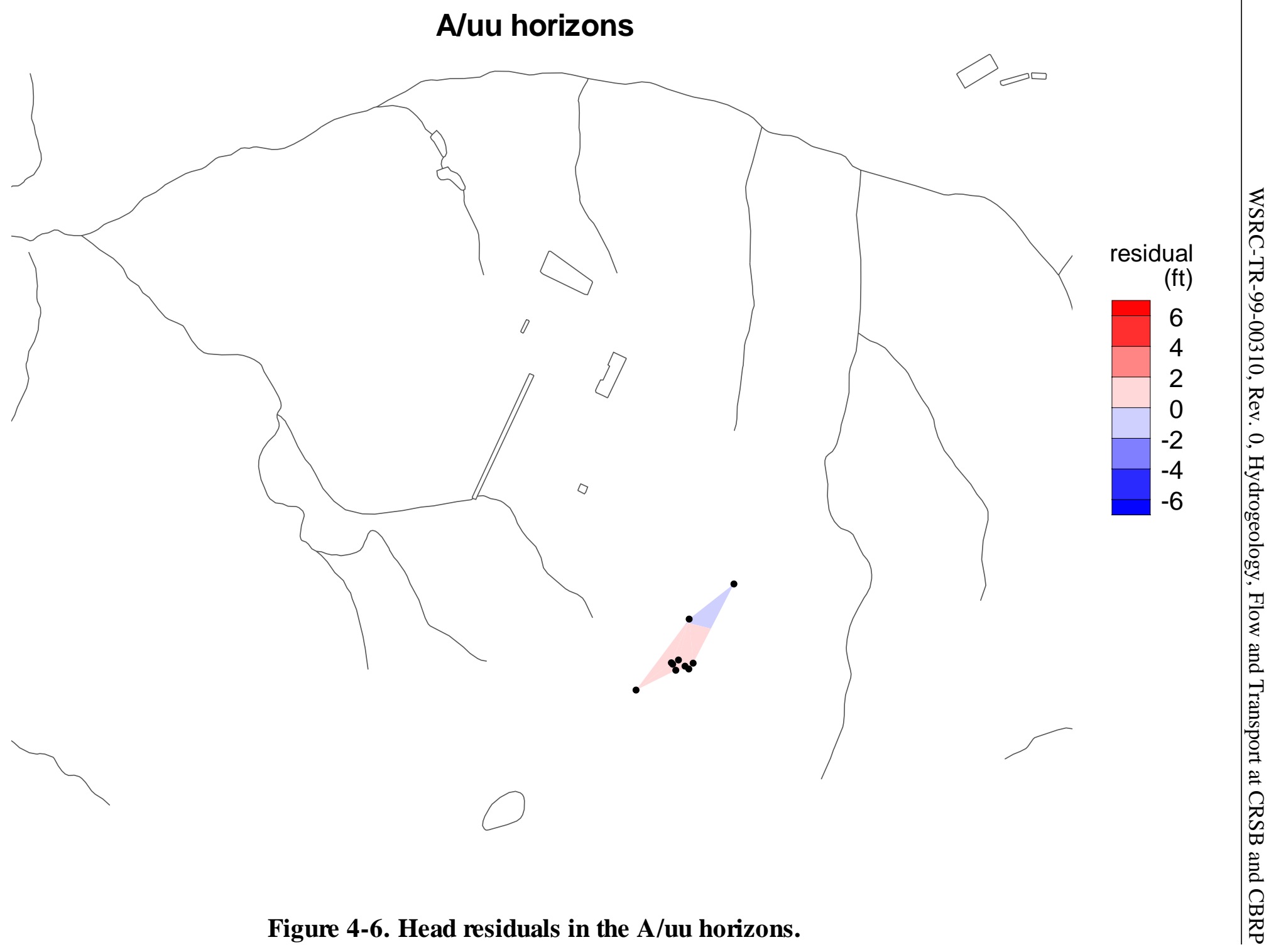



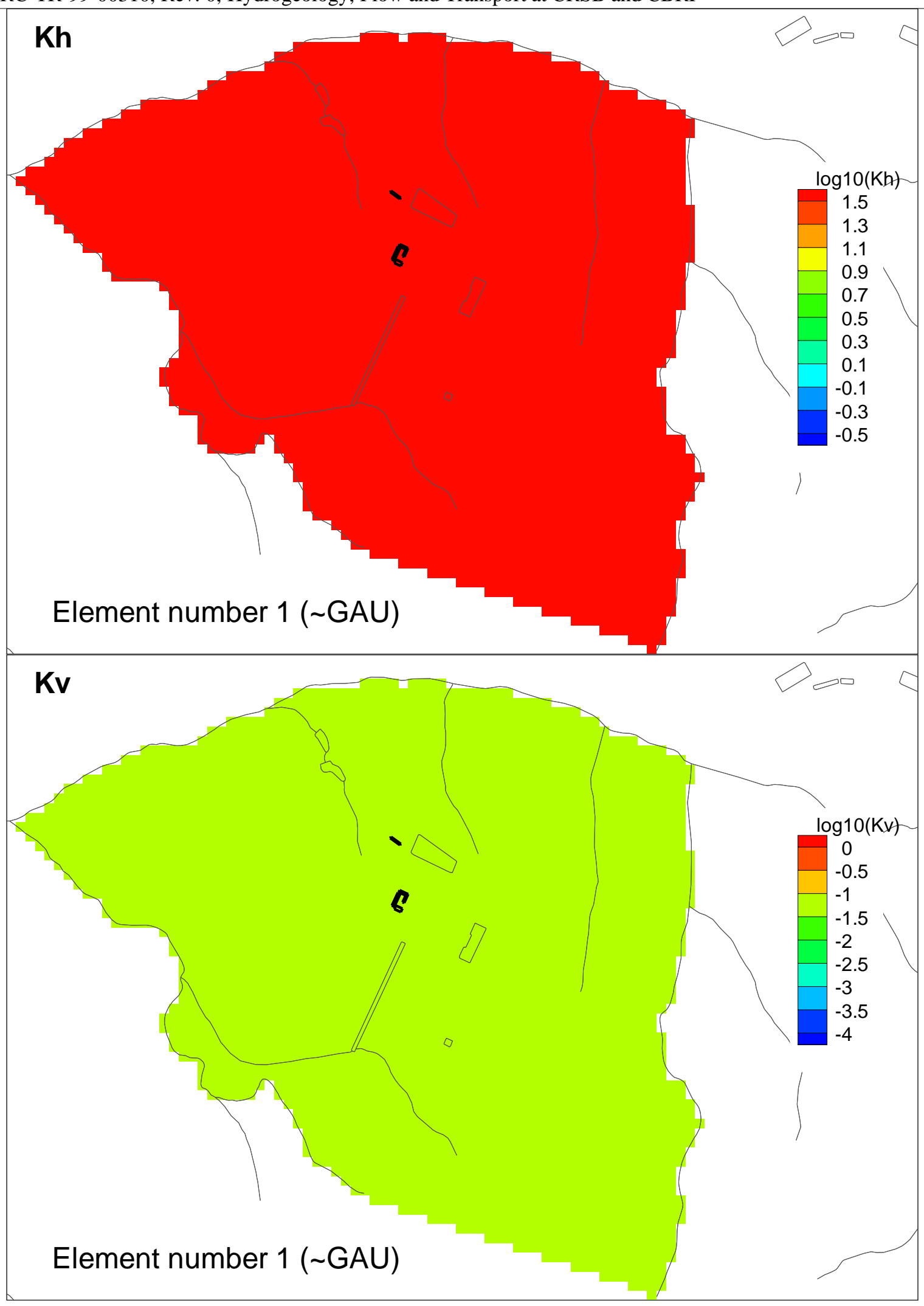

Figure 4-7. Hydraulic conductivities in element layer 1 (GAU except outcrops). 


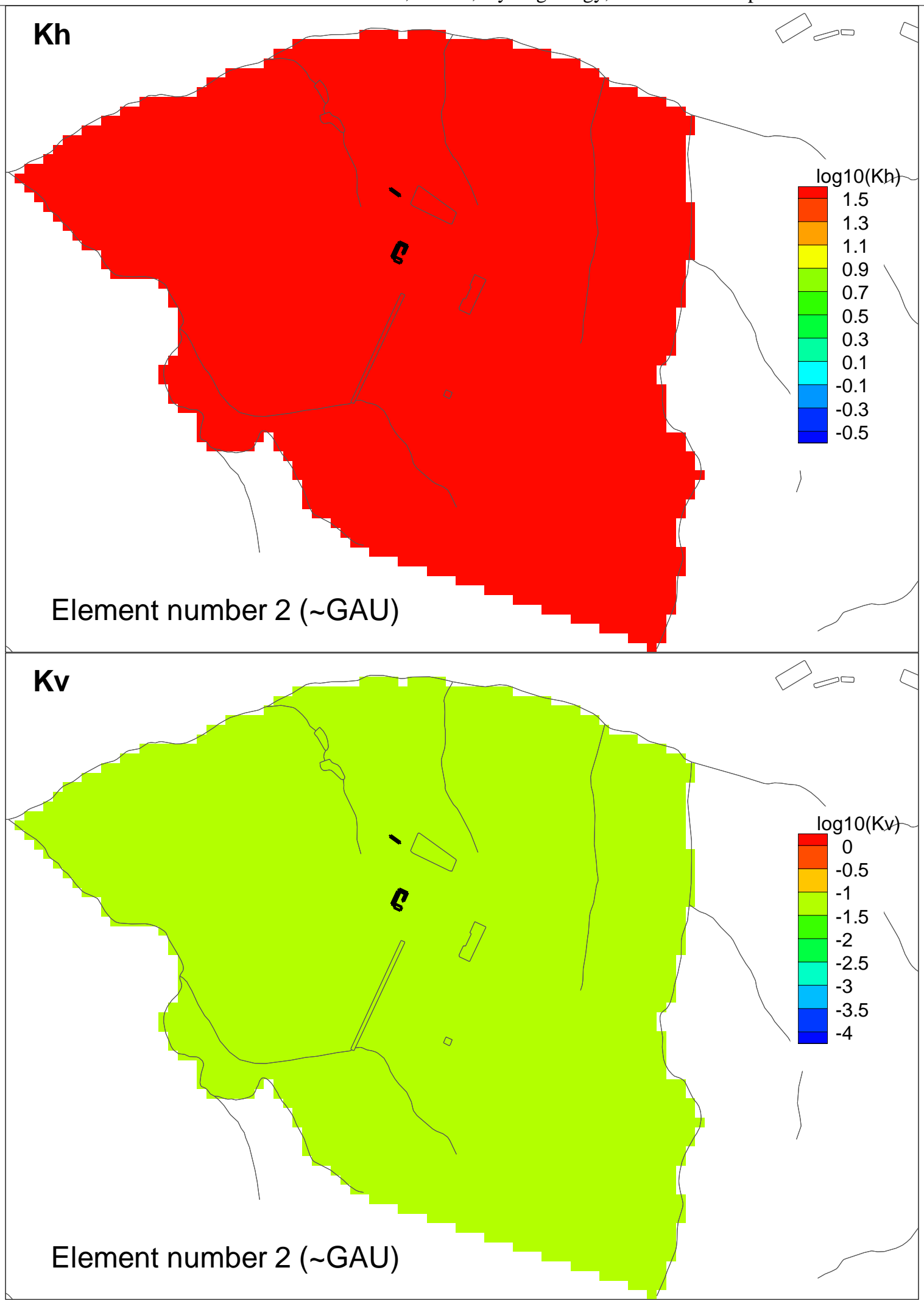

Figure 4-8. Hydraulic conductivities in element layer 2 (GAU except outcrops). 

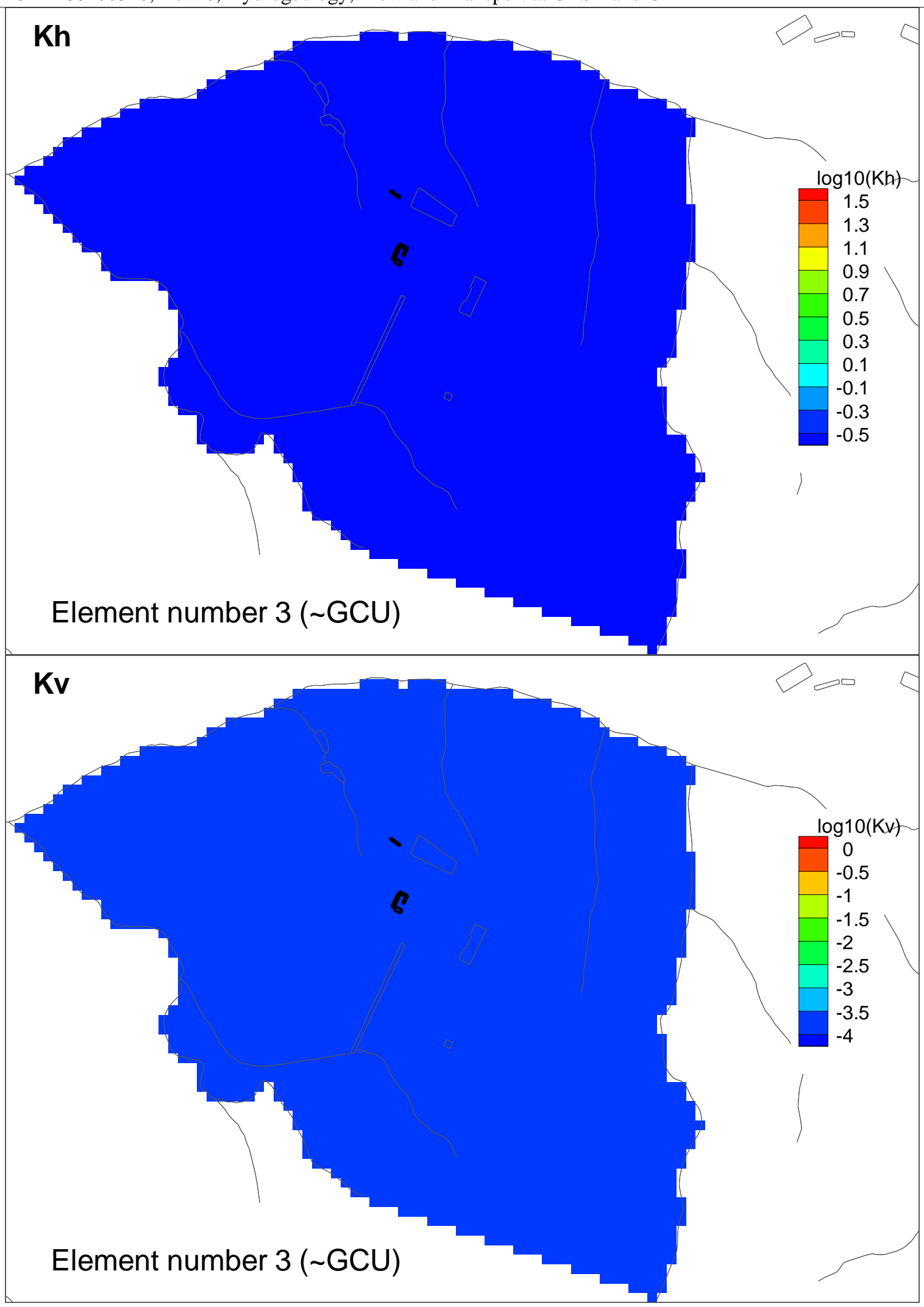

Figure 4-9. Hydraulic conductivities in element layer 3 (GCU except outcrops). 


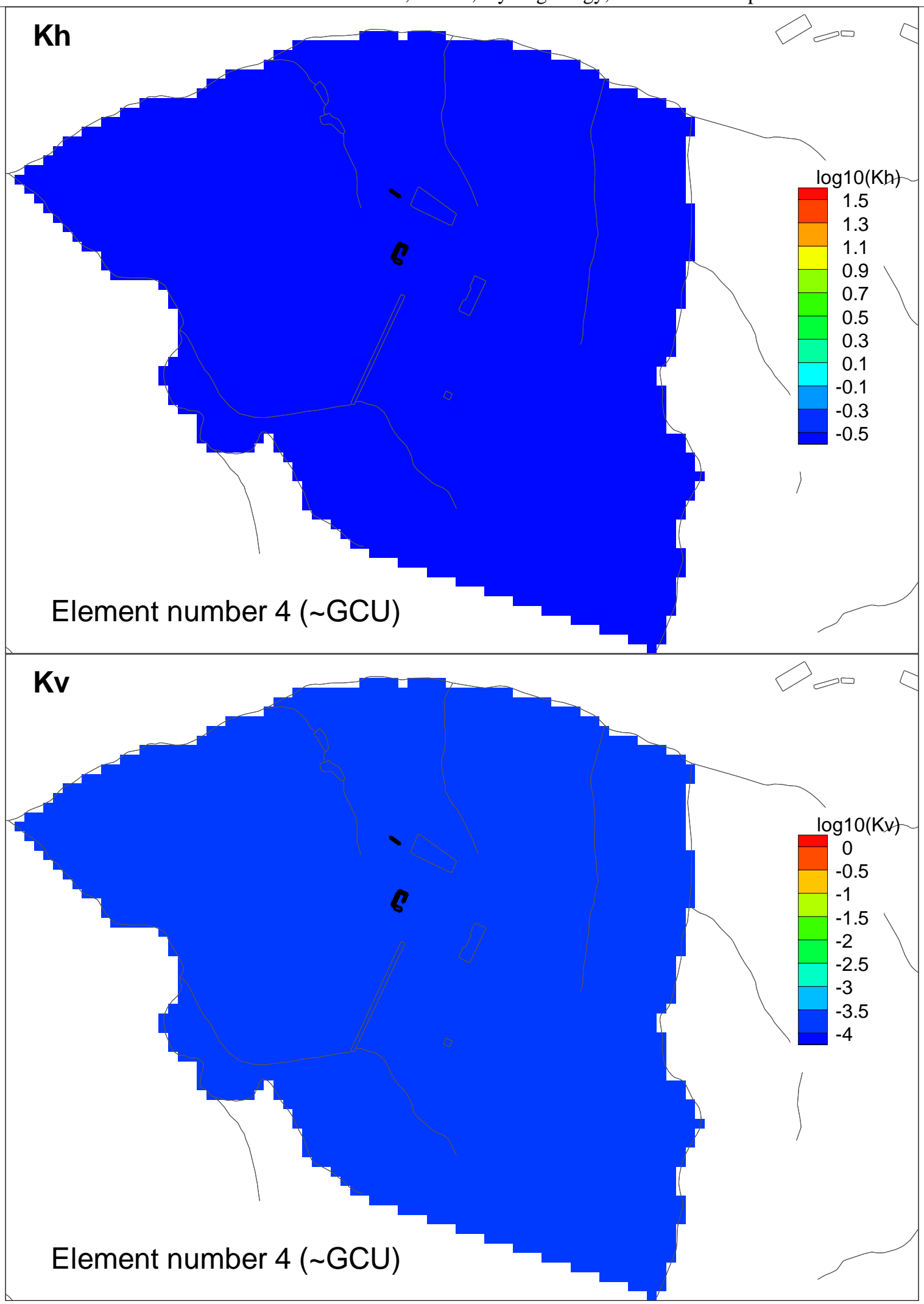

Figure 4-10. Hydraulic conductivities in element layer 4 (GCU except outcrops). 

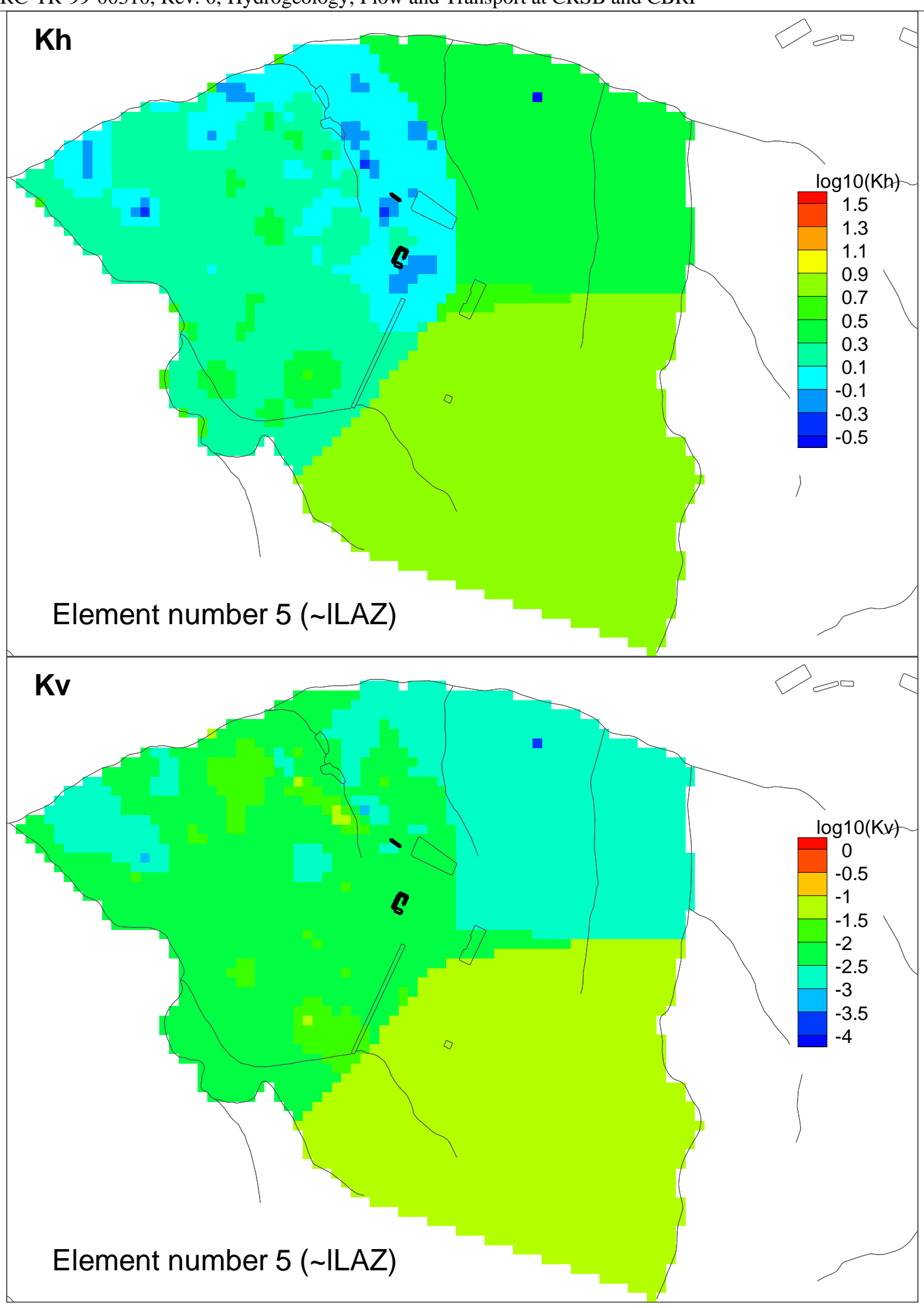

Figure 4-11. Hydraulic conductivities in element layer 5 (ILAZ except outcrops). 


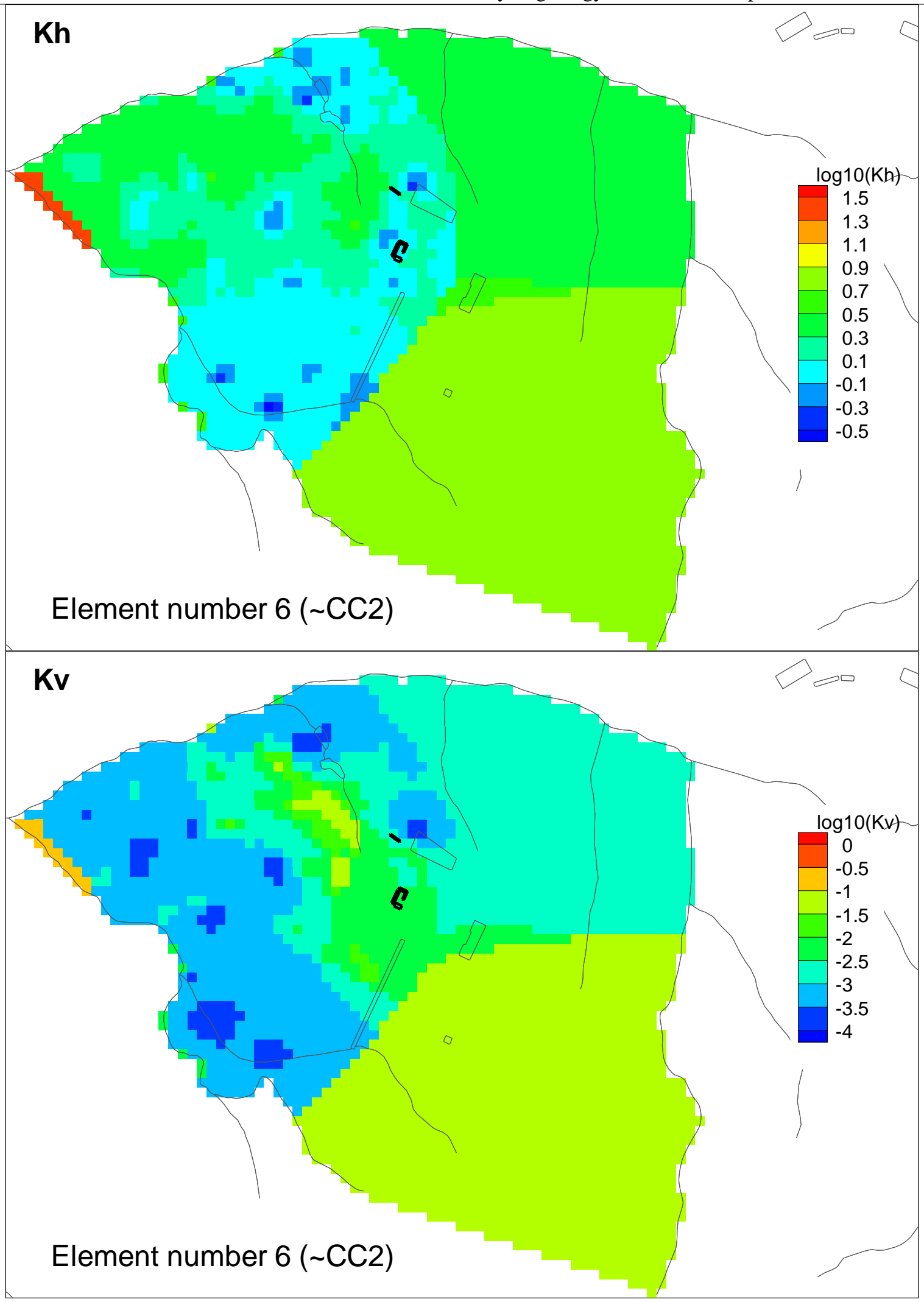

Figure 4-12. Hydraulic conductivities in element layer 6 (CC2 except outcrops). 

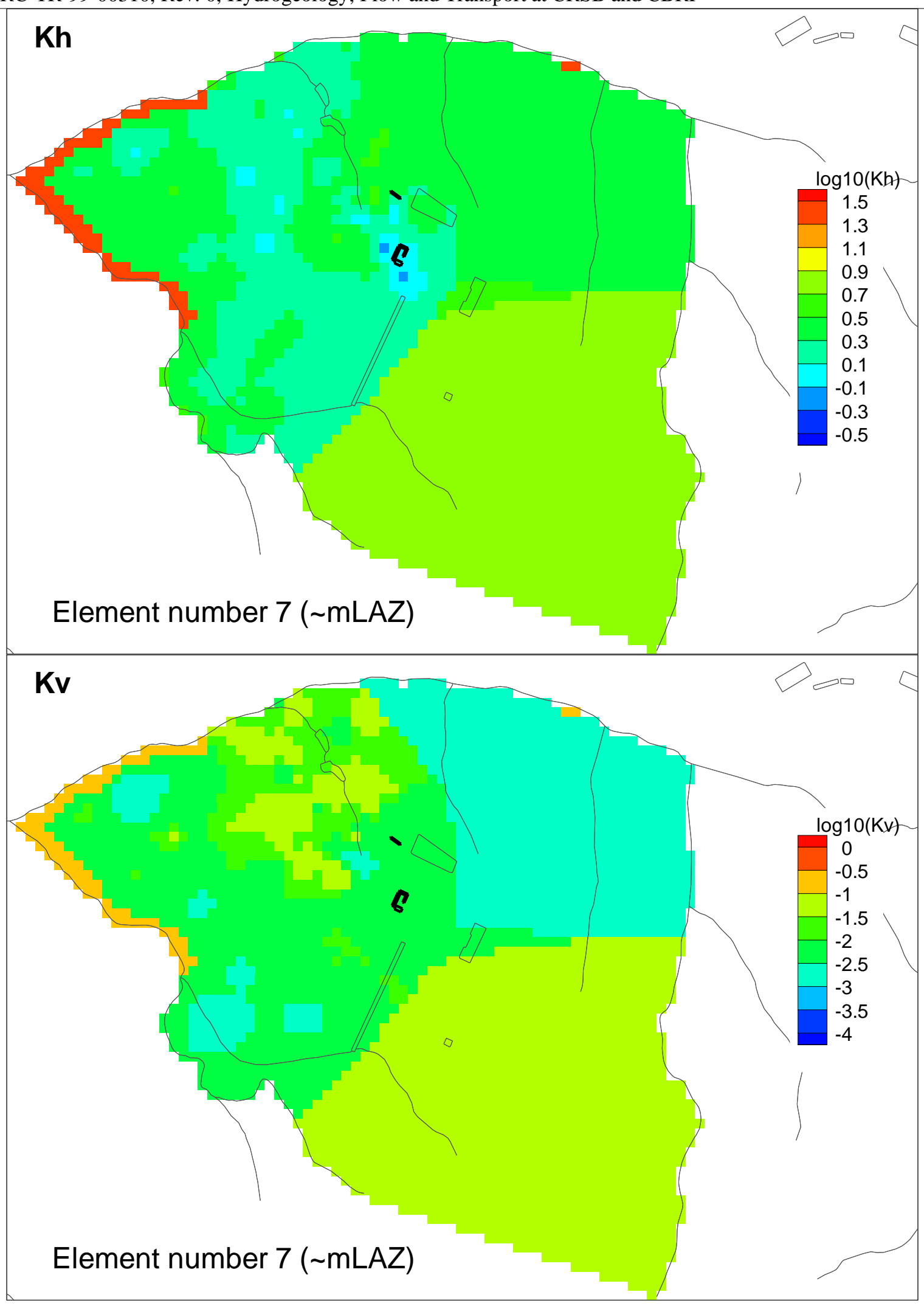

Figure 4-13. Hydraulic conductivities in element layer 7 (mLAZ except outcrops). 

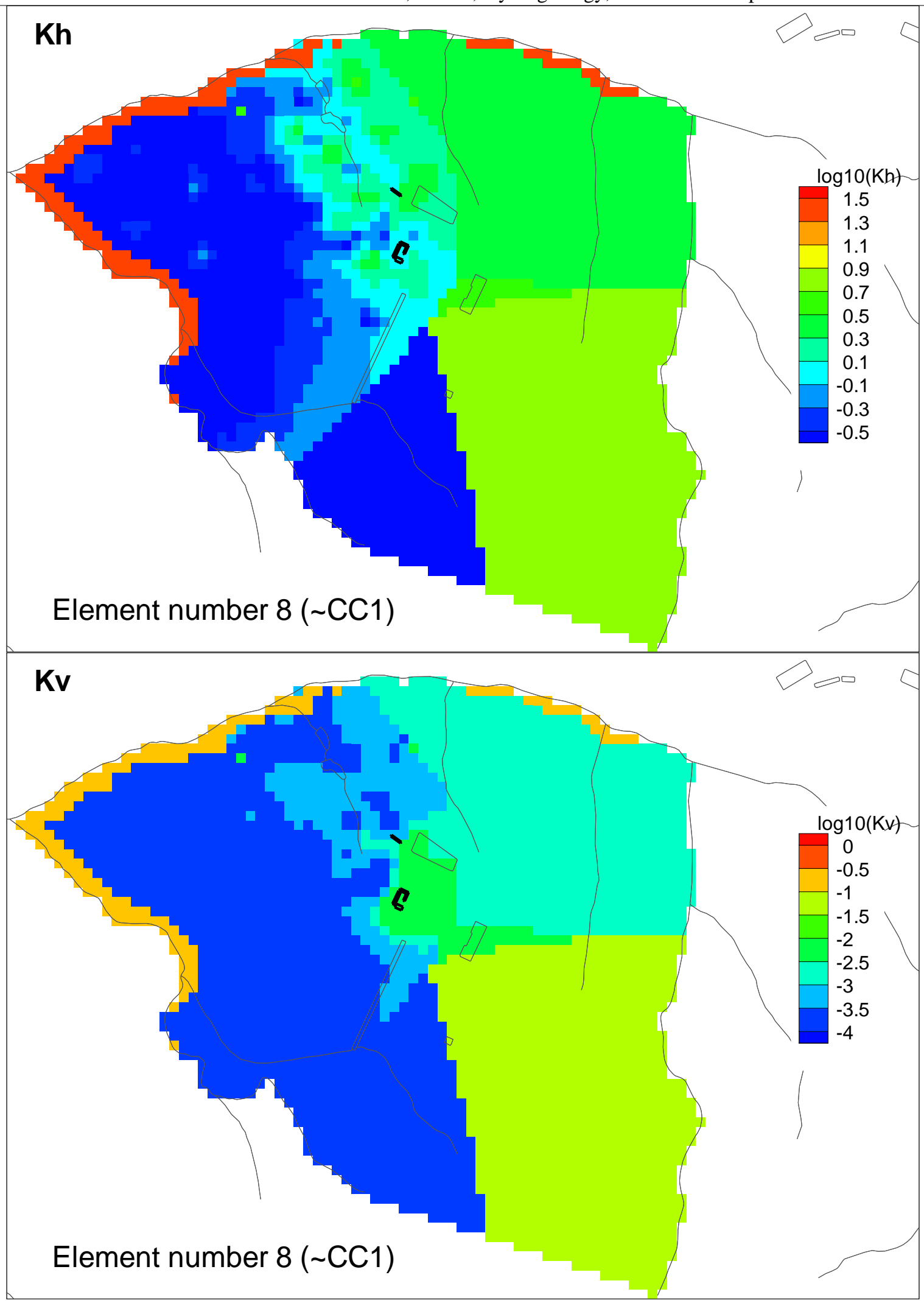

Figure 4-14. Hydraulic conductivities in element layer 8 (CC1 except outcrops). 

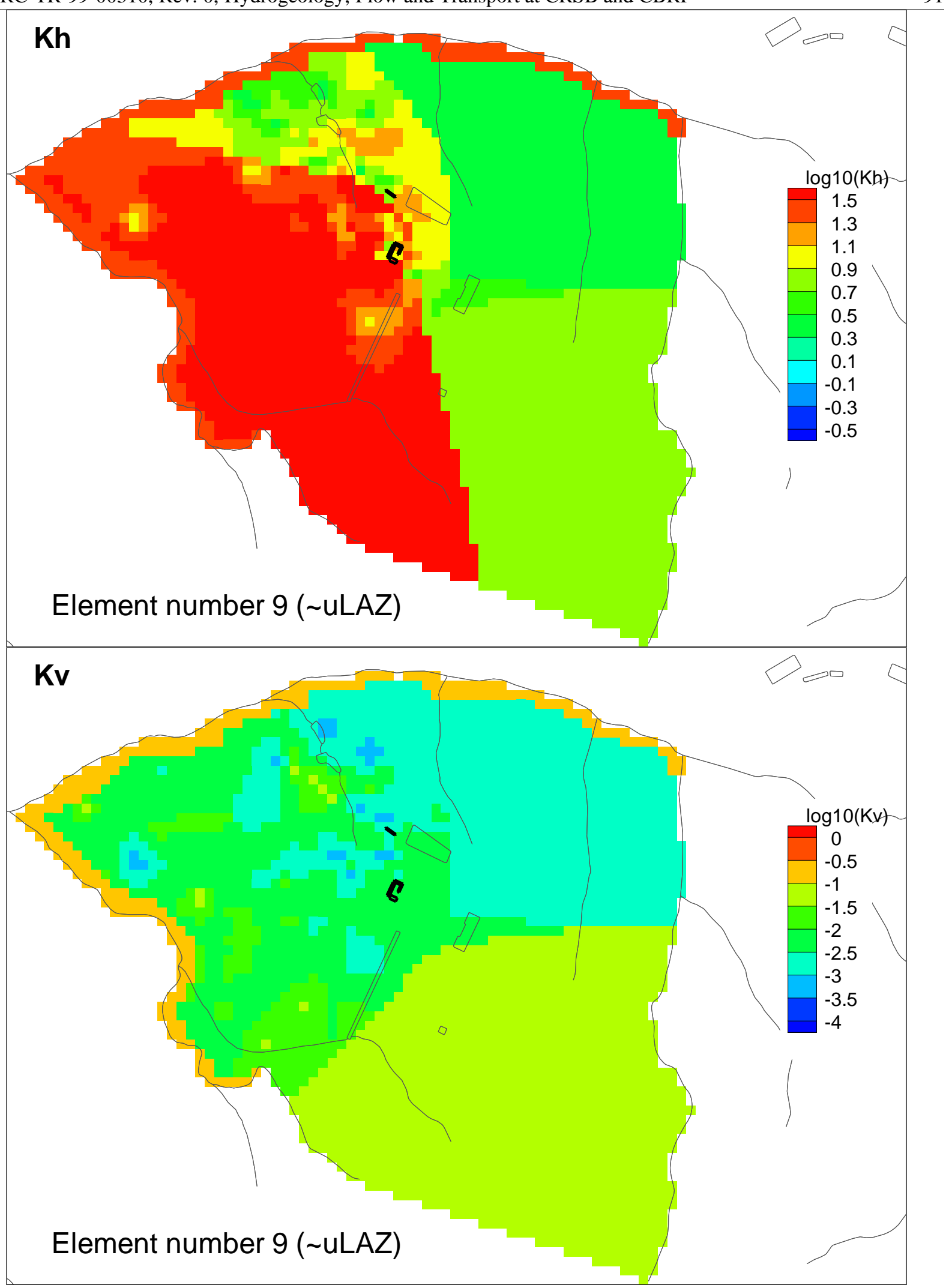

Figure 4-15. Hydraulic conductivities in element layer 9 (uLAZ except outcrops). 


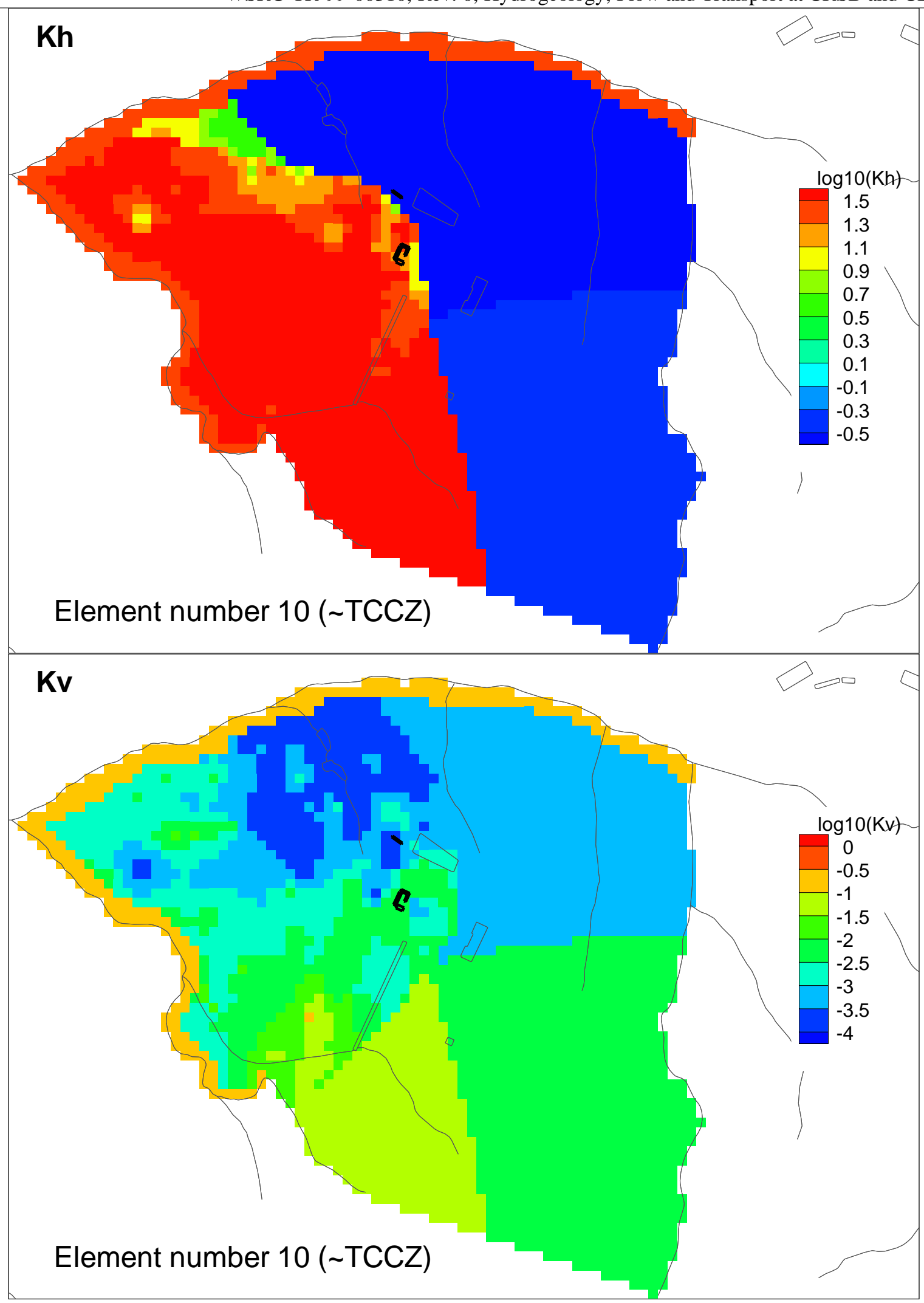

Figure 4-16. Hydraulic conductivities in element layer 10 (TCCZ except outcrops). 

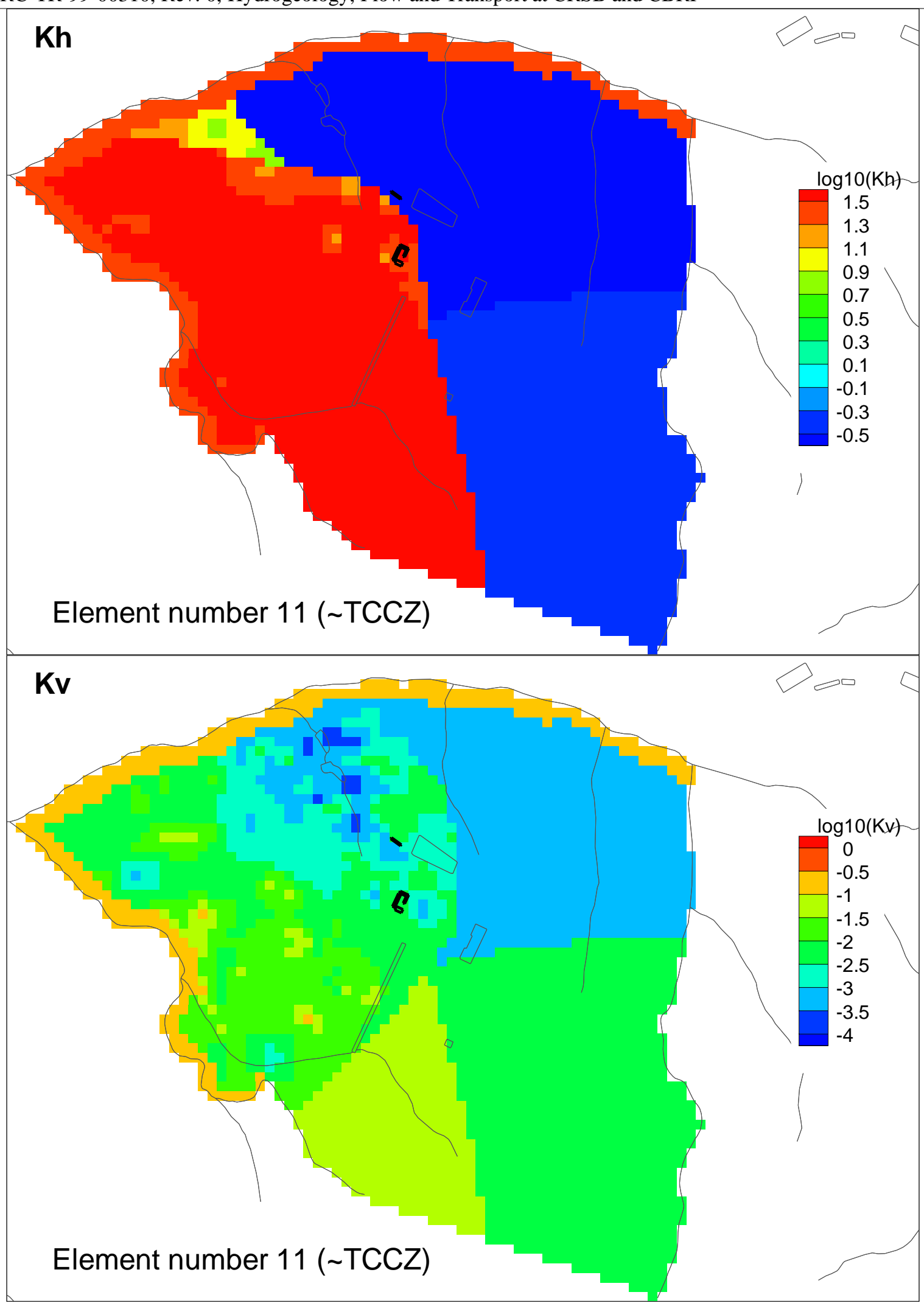

Figure 4-17. Hydraulic conductivities in element layer 11 (TCCZ except outcrops). 


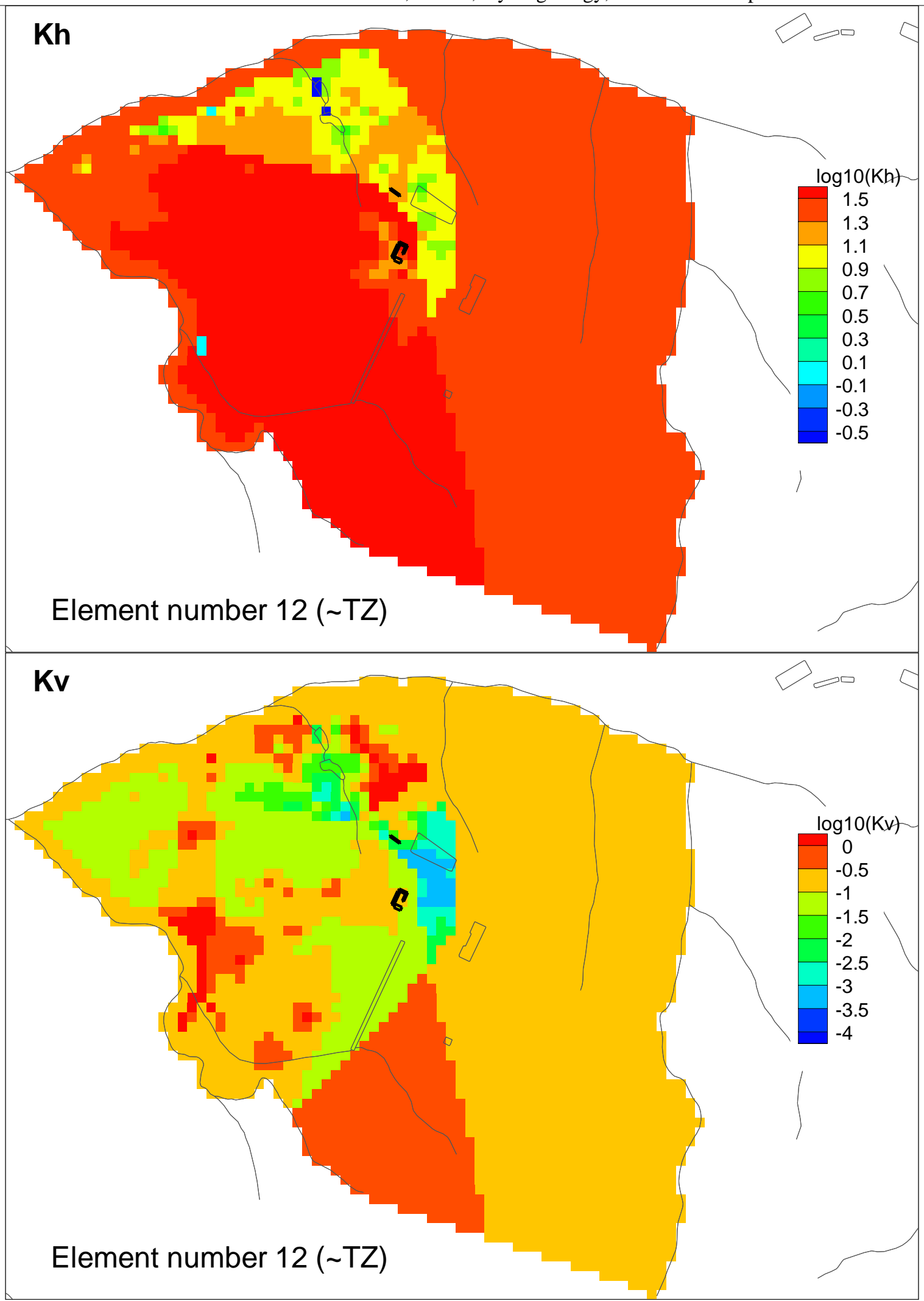

Figure 4-18. Hydraulic conductivities in element layer 12 (TZ except outcrops). 

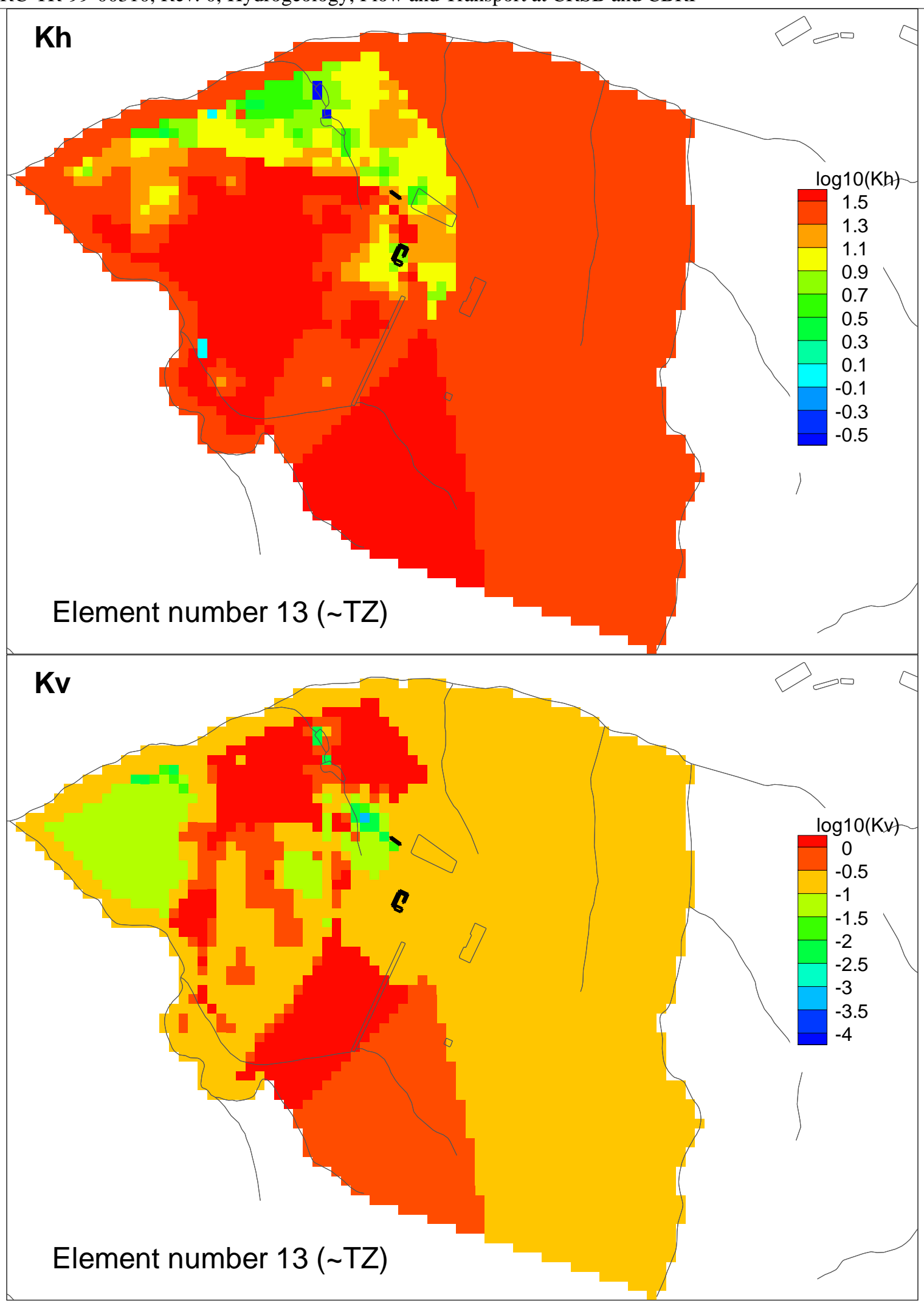

Figure 4-19. Hydraulic conductivities in element layer 13 (TZ except outcrops). 


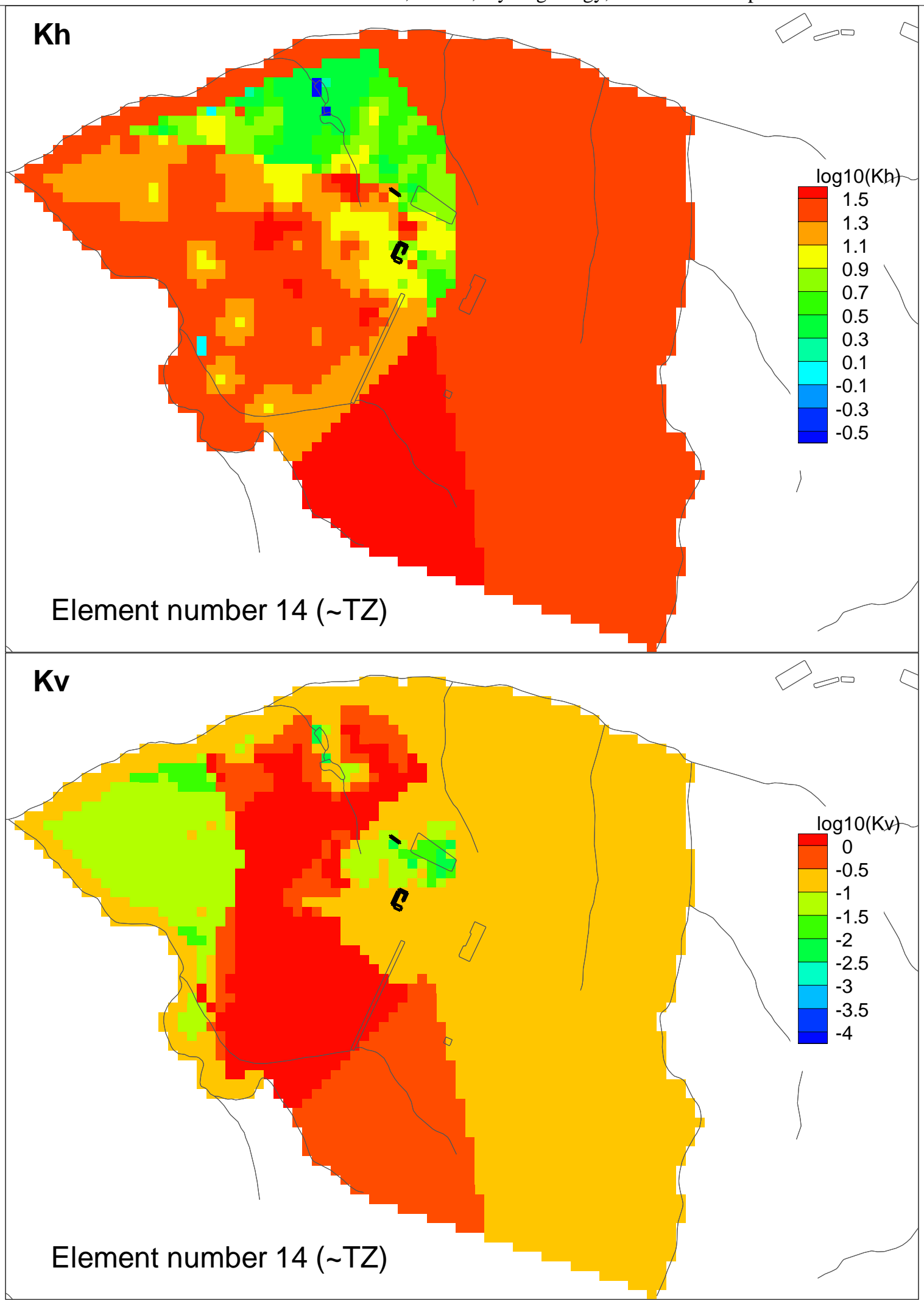

Figure 4-20. Hydraulic conductivities in element layer 14 (TZ except outcrops). 

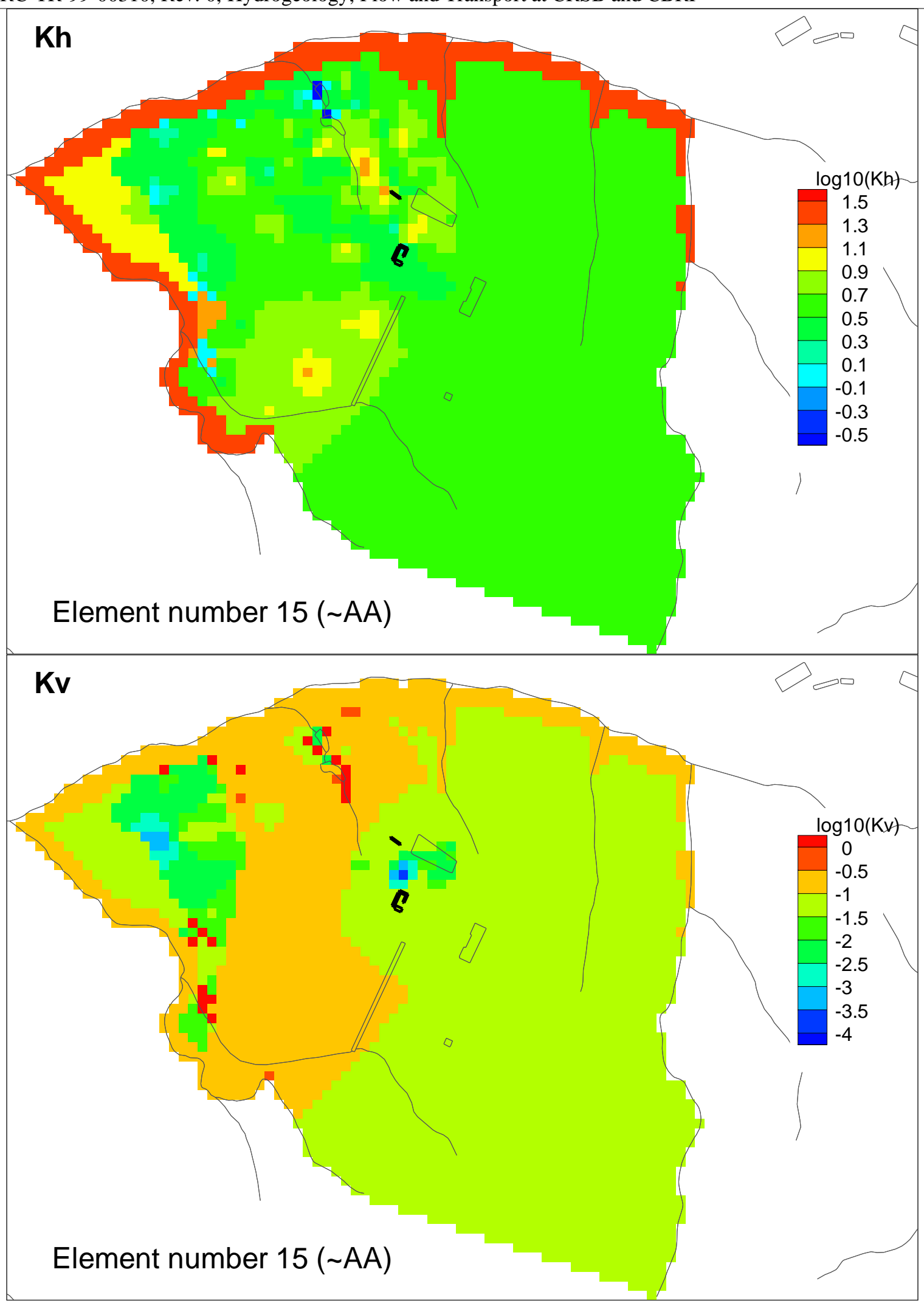

Figure 4-21. Hydraulic conductivities in element layer 15 (AA except outcrops). 


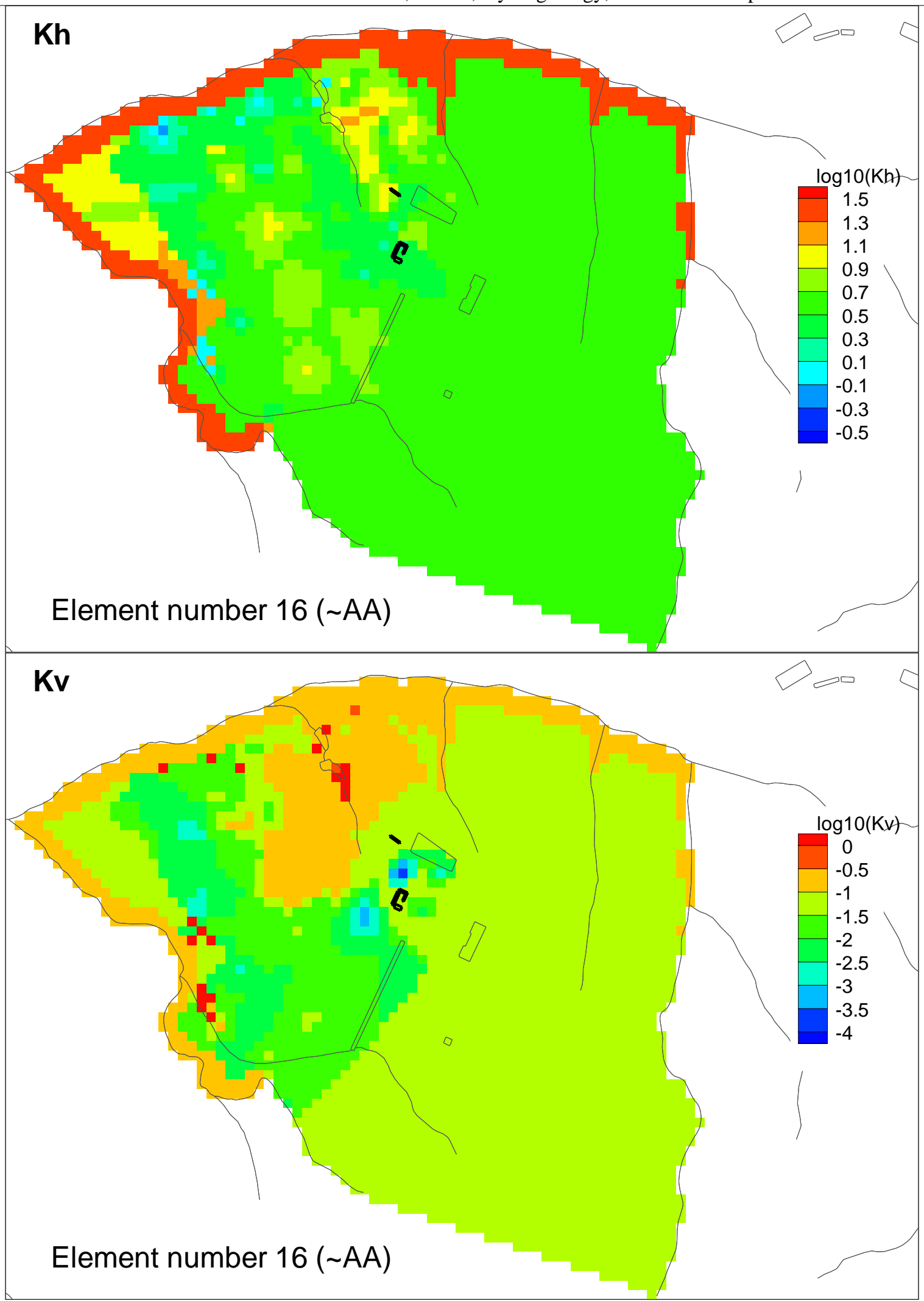

Figure 4-22. Hydraulic conductivities in element layer 16 (AA except outcrops). 

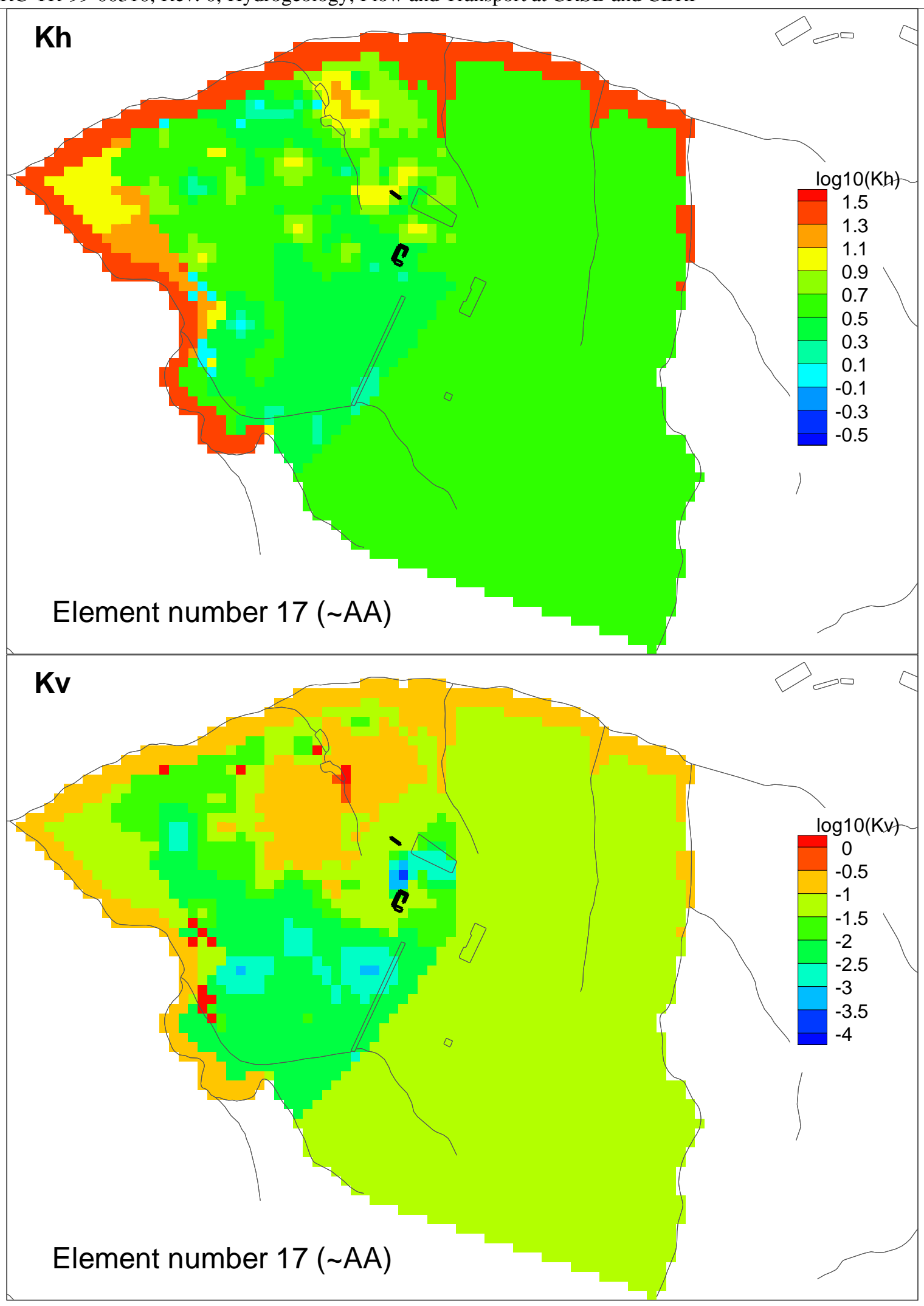

Figure 4-23. Hydraulic conductivities in element layer 17 (AA except outcrops). 


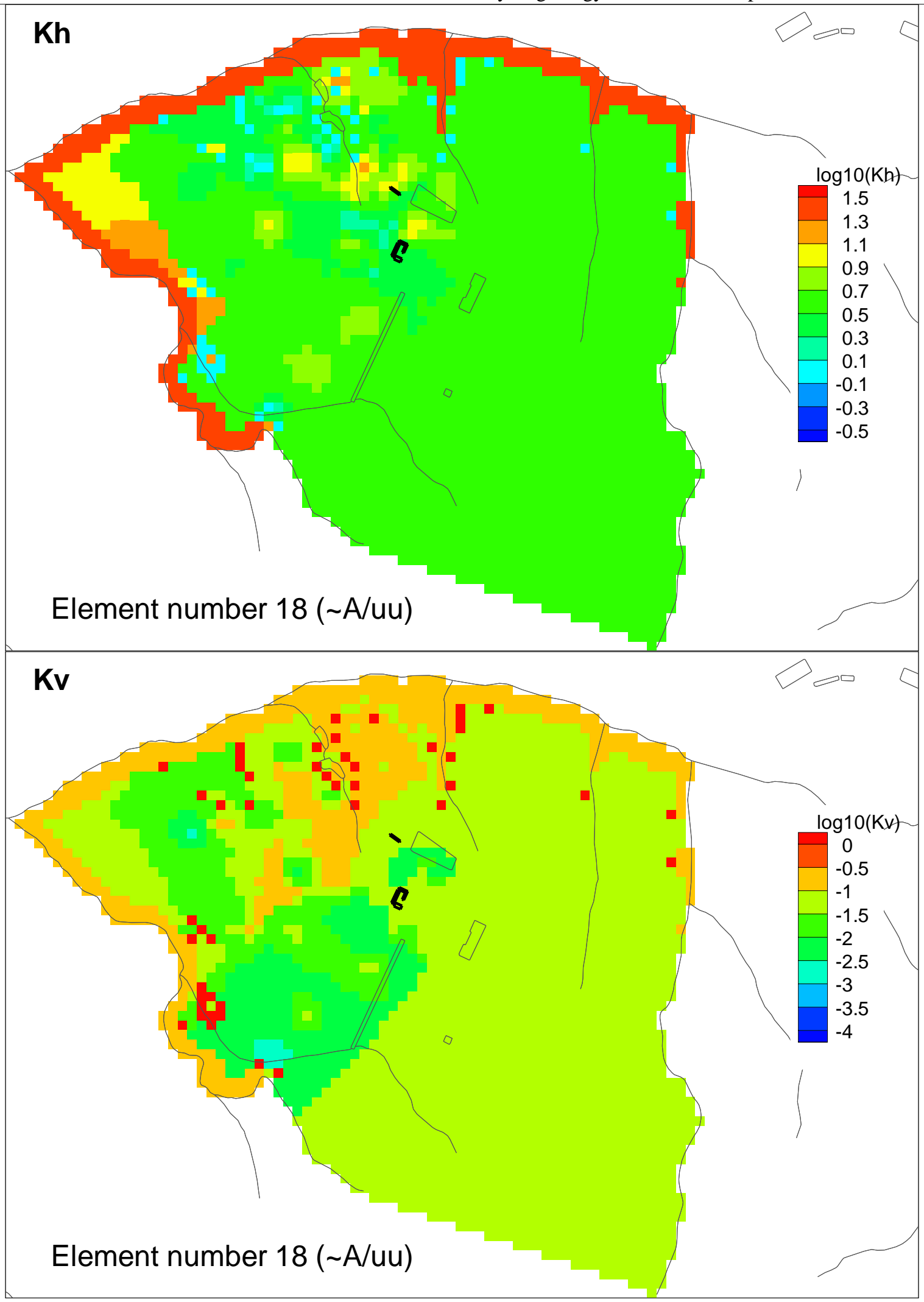

Figure 4-24. Hydraulic conductivities in element layer 18 (A/uu except outcrops). 

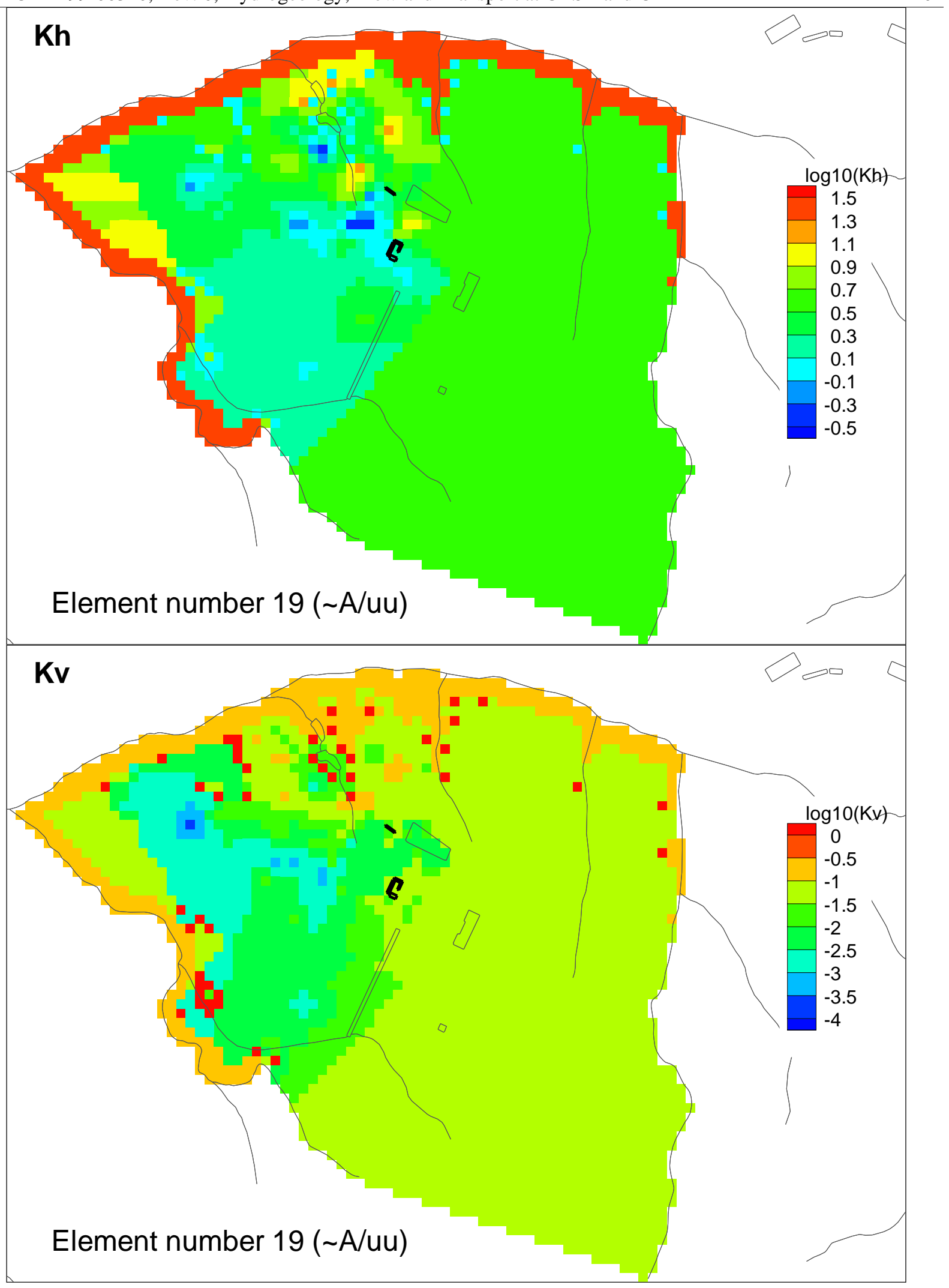

Figure 4-25. Hydraulic conductivities in element layer 19 (A/uu except outcrops). 


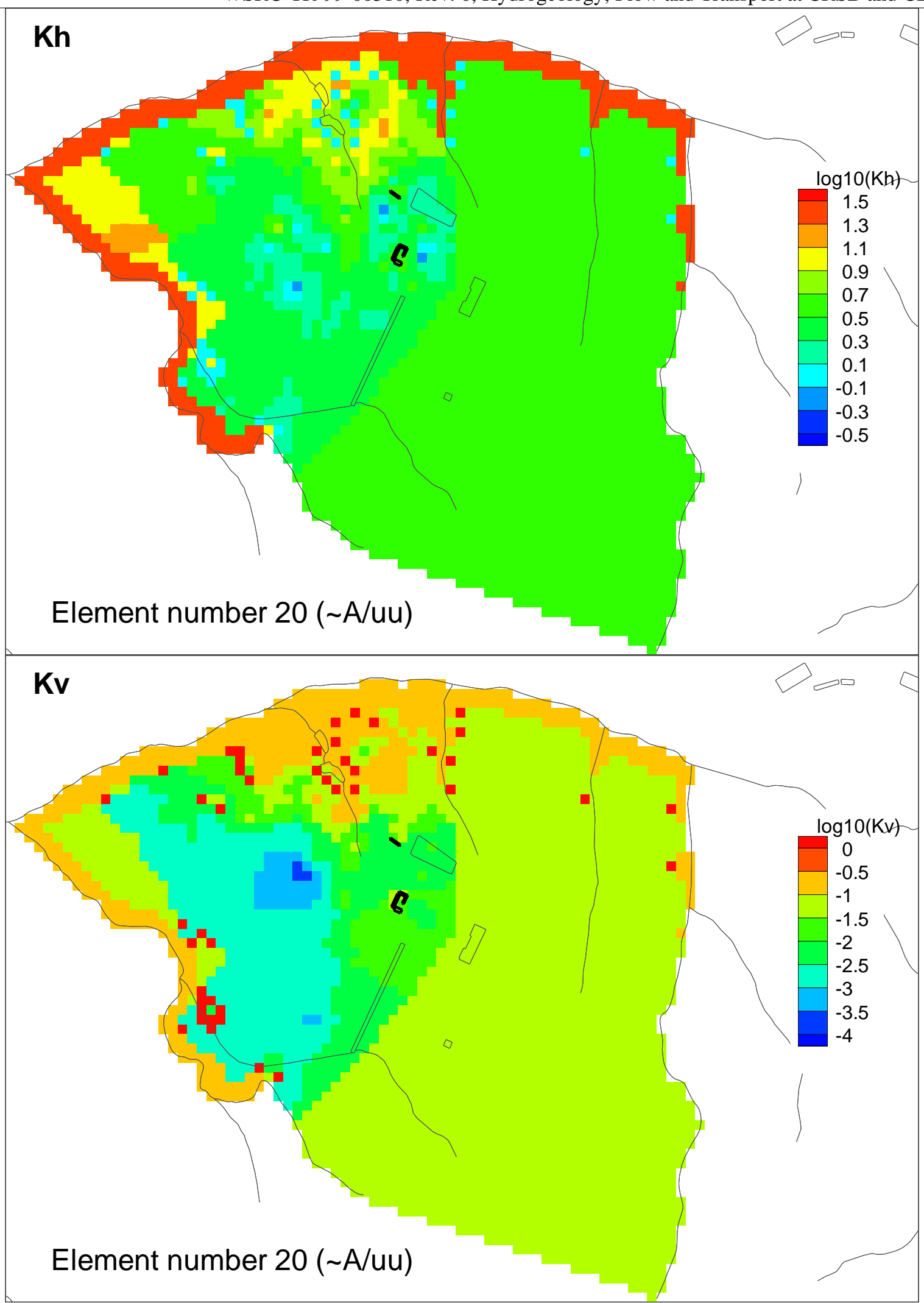

Figure 4-26. Hydraulic conductivities in element layer 20 (A/uu except outcrops). 


\section{Simulated hydraulic head in Gordon aquifer unit}

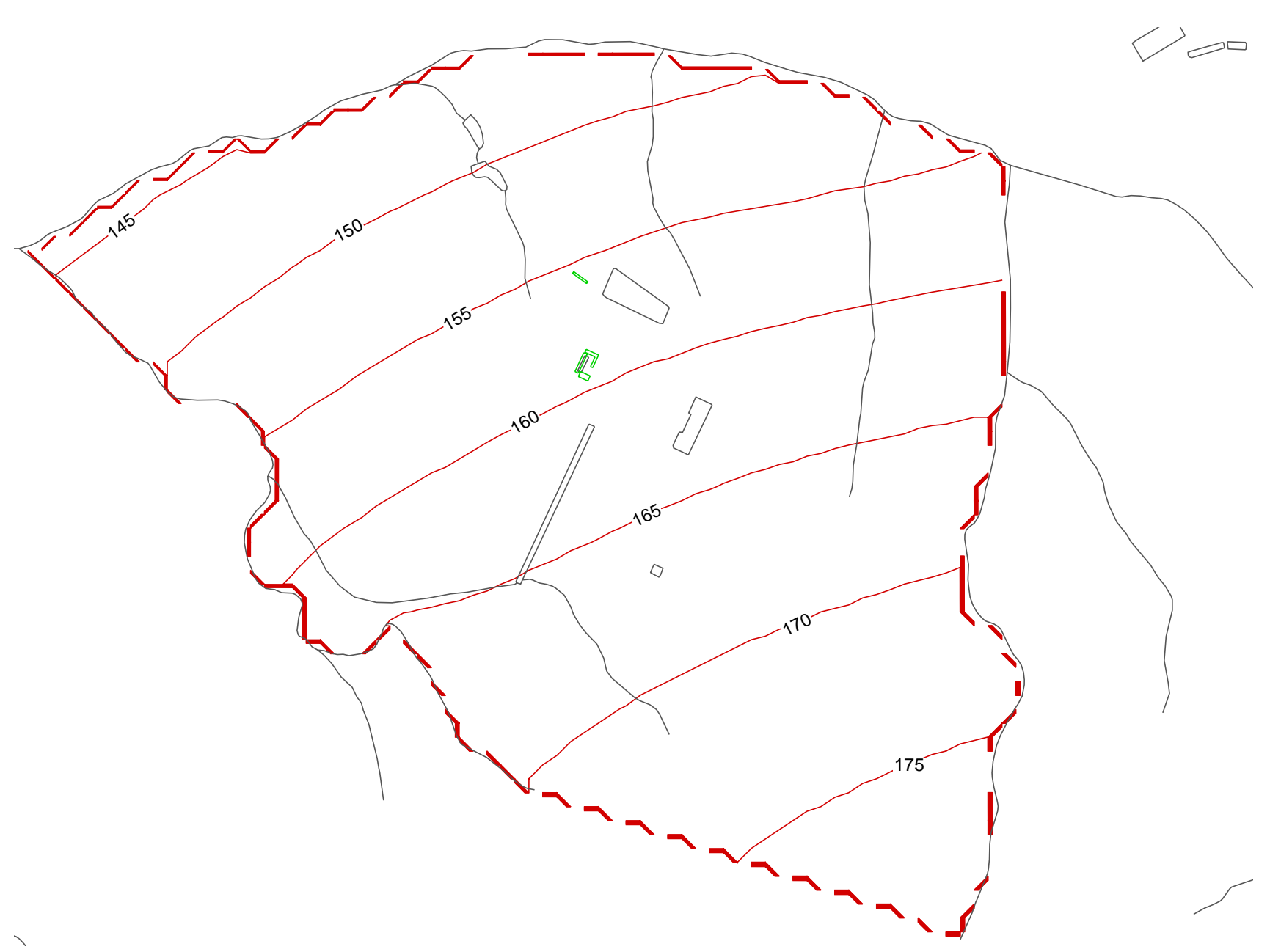

Figure 4-27. Simulated head in the Gordon aquifer. 
Simulated hydraulic head in "lower" UTR aquifer zone

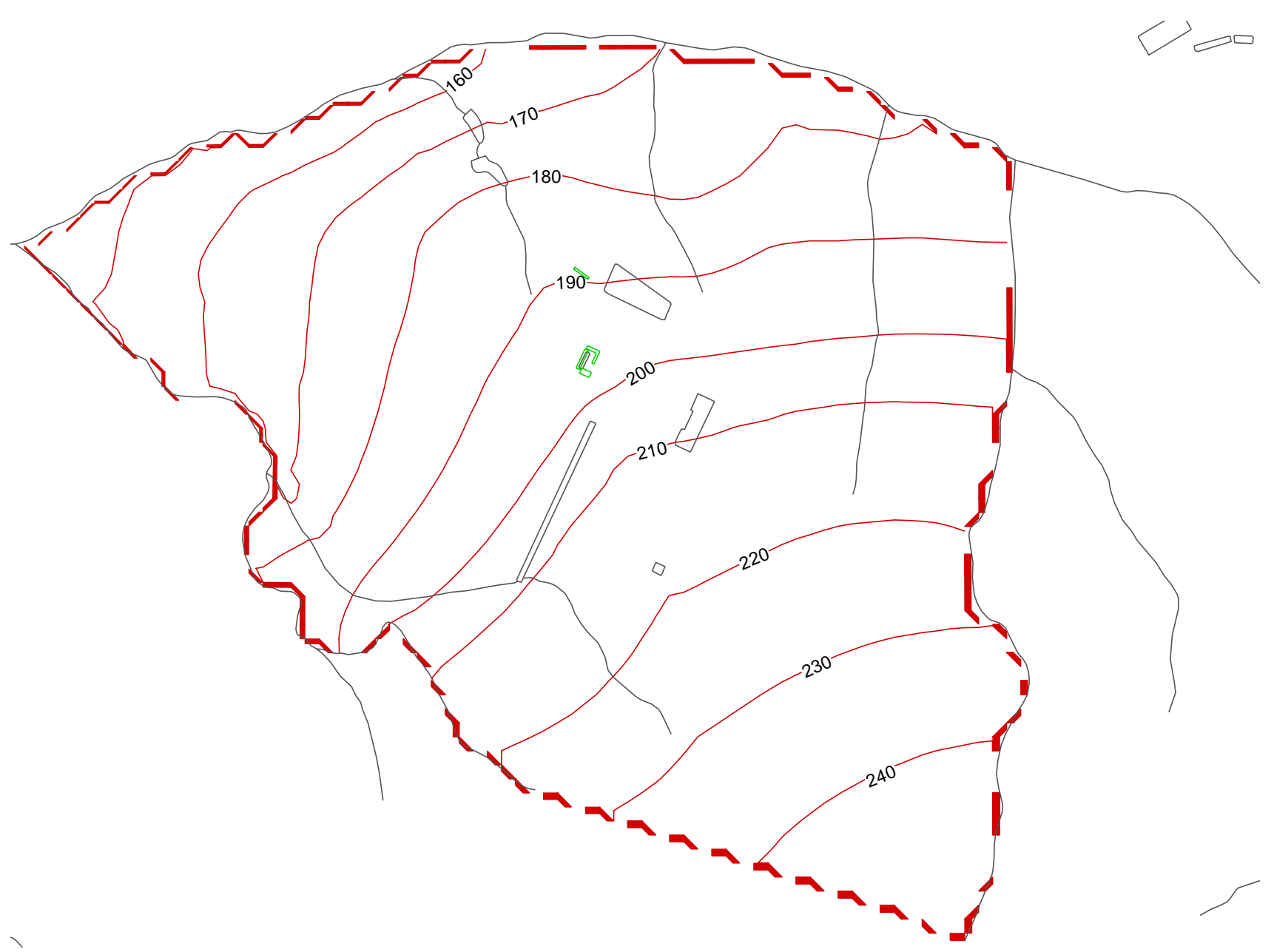

Figure 4-28. Simulated head in the lower UTRA. 


\section{Simulated hydraulic head in "upper" UTR aquifer zone}

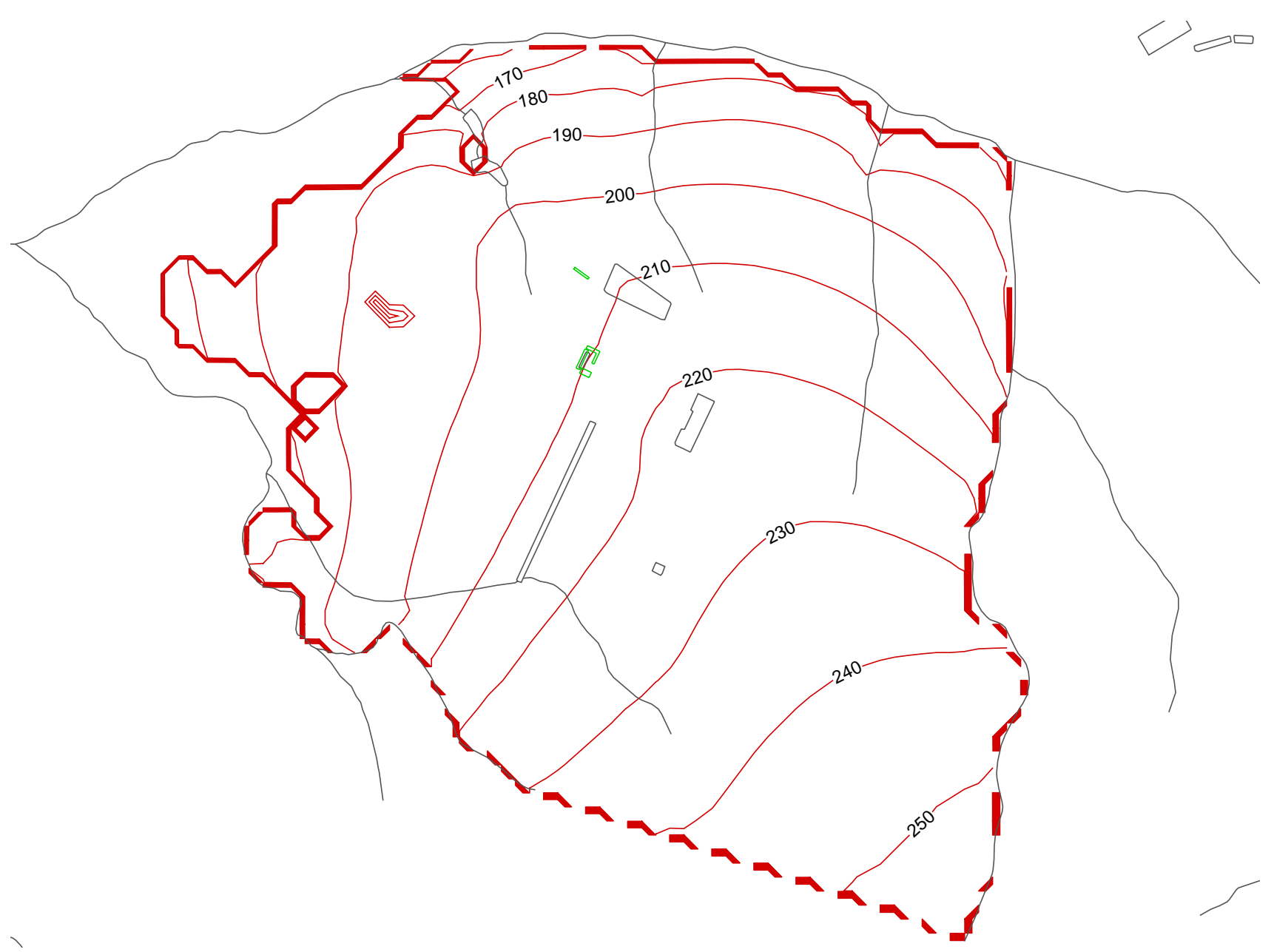

Figure 4-29. Simulated head in the upper UTRA. 
Simulated hydraulic head in aquifer zone containing water table

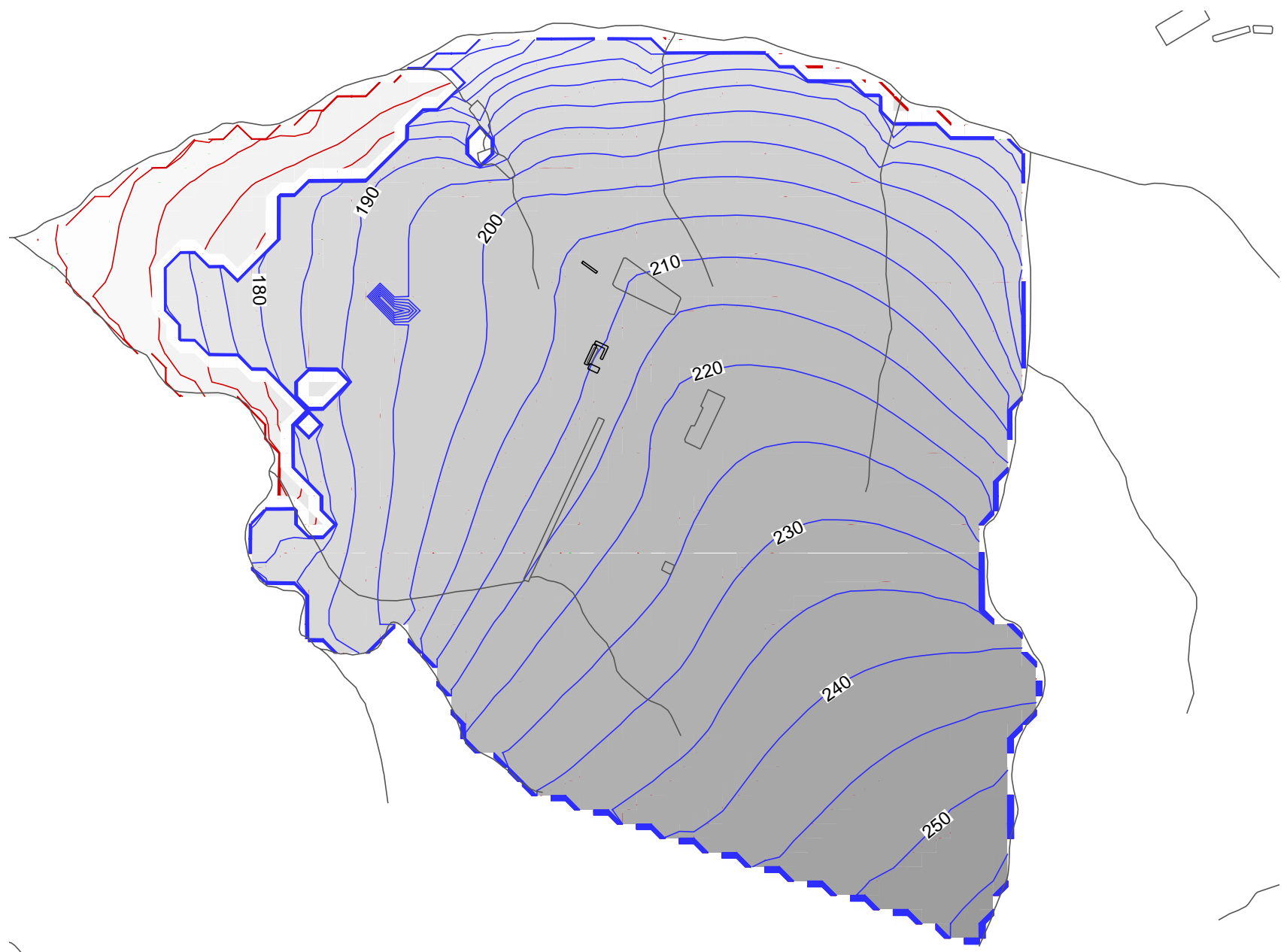

Figure 4-30. Simulated head in the aquifer zone containing the water table. 


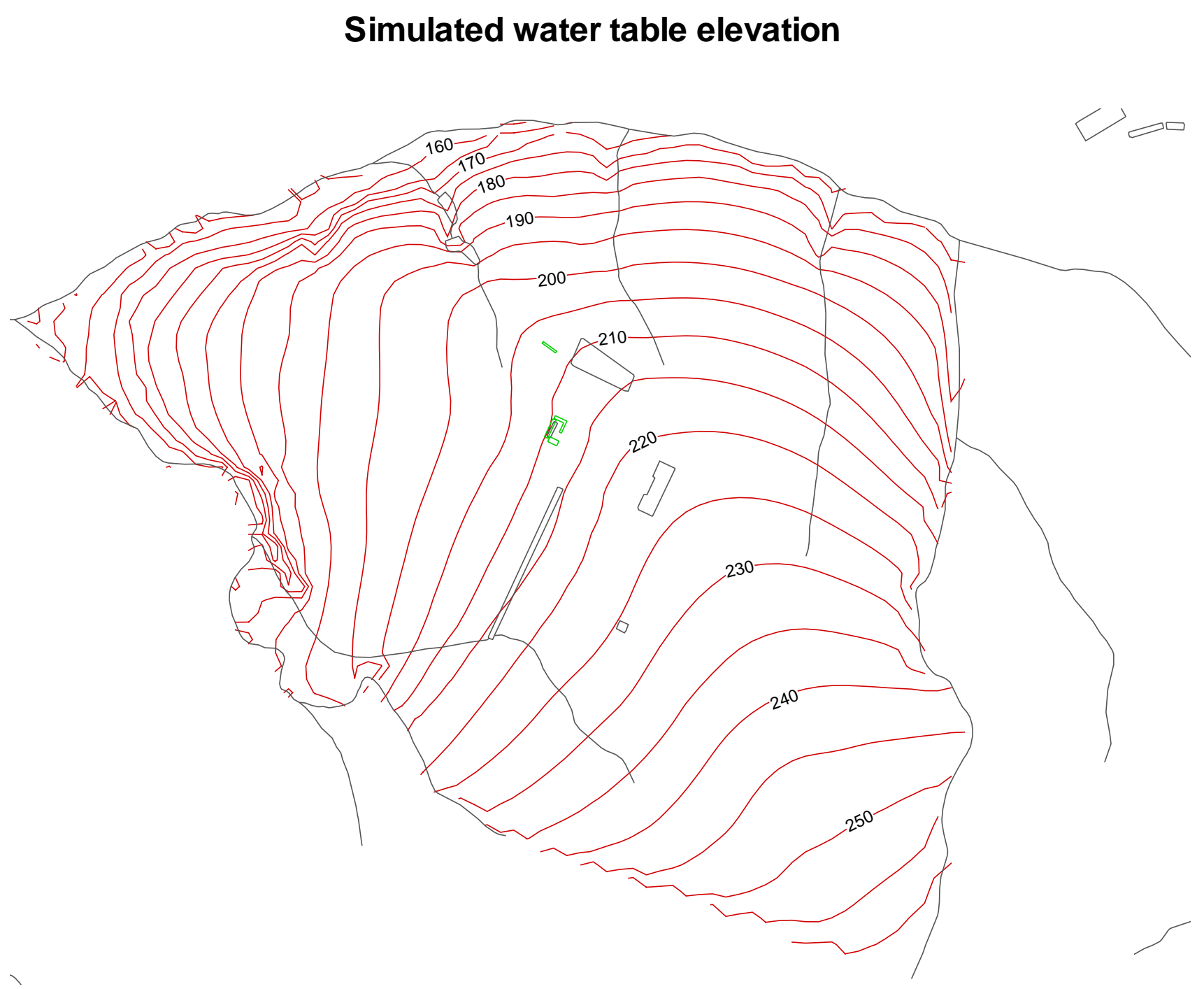




\section{Groundwater flow directions in Gordon aquifer unit}

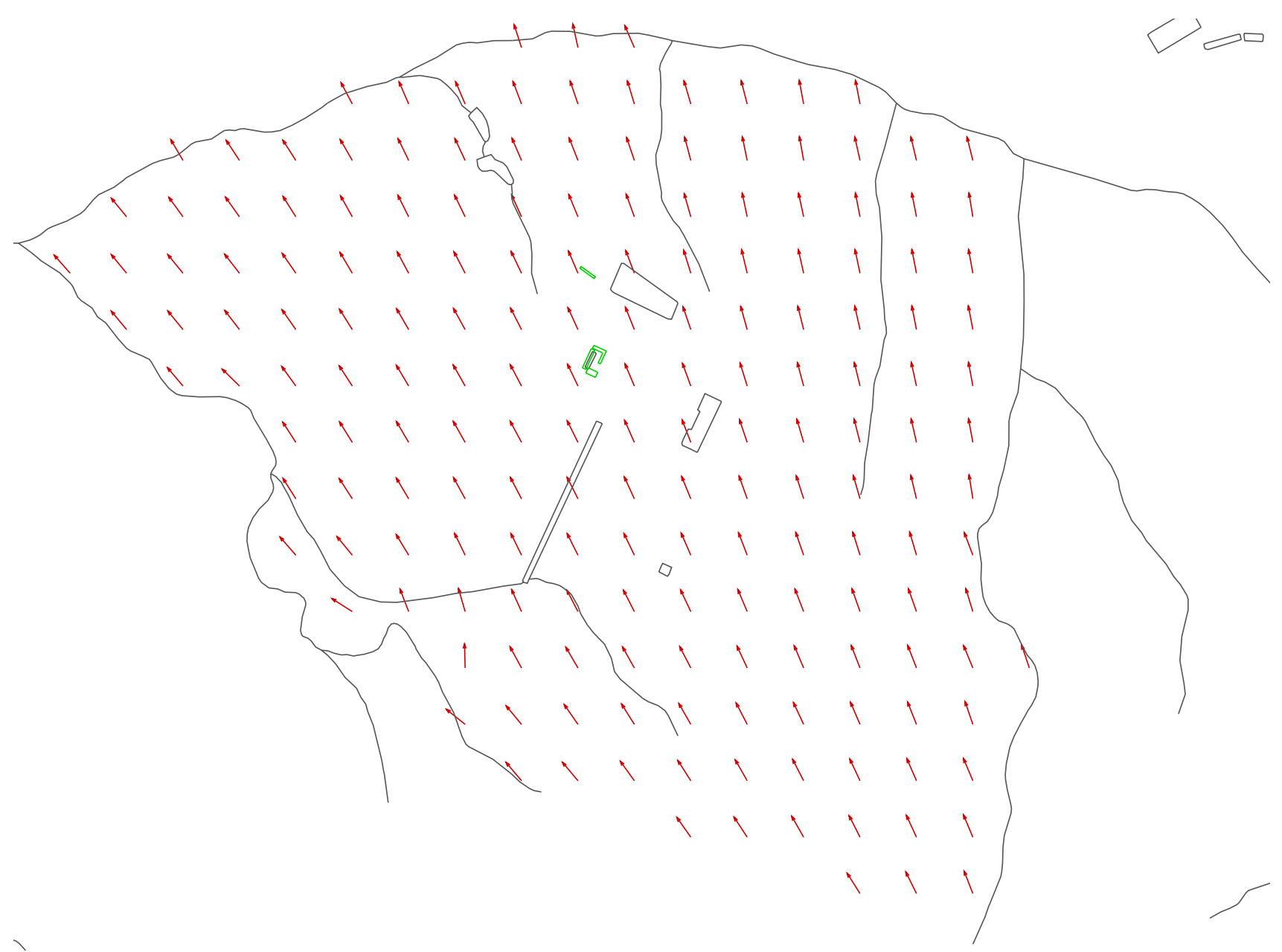

Figure 4-32. Simulated flow directions in the Gordon aquifer. 
Groundwater flow directions in Upper Three Runs aquifer unit, "lower" zone

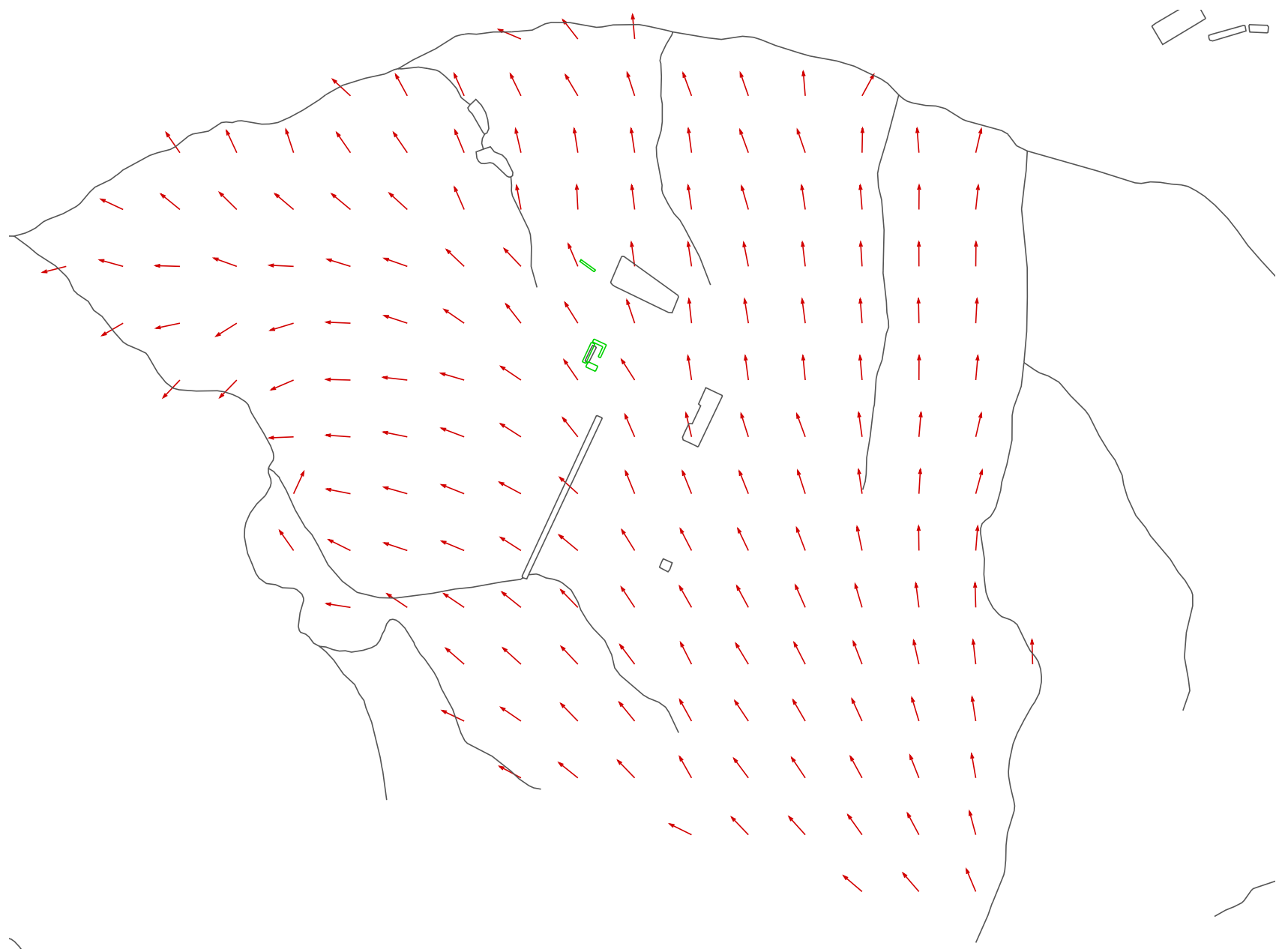

Figure 4-33. Simulated flow directions in the lower UTRA. 


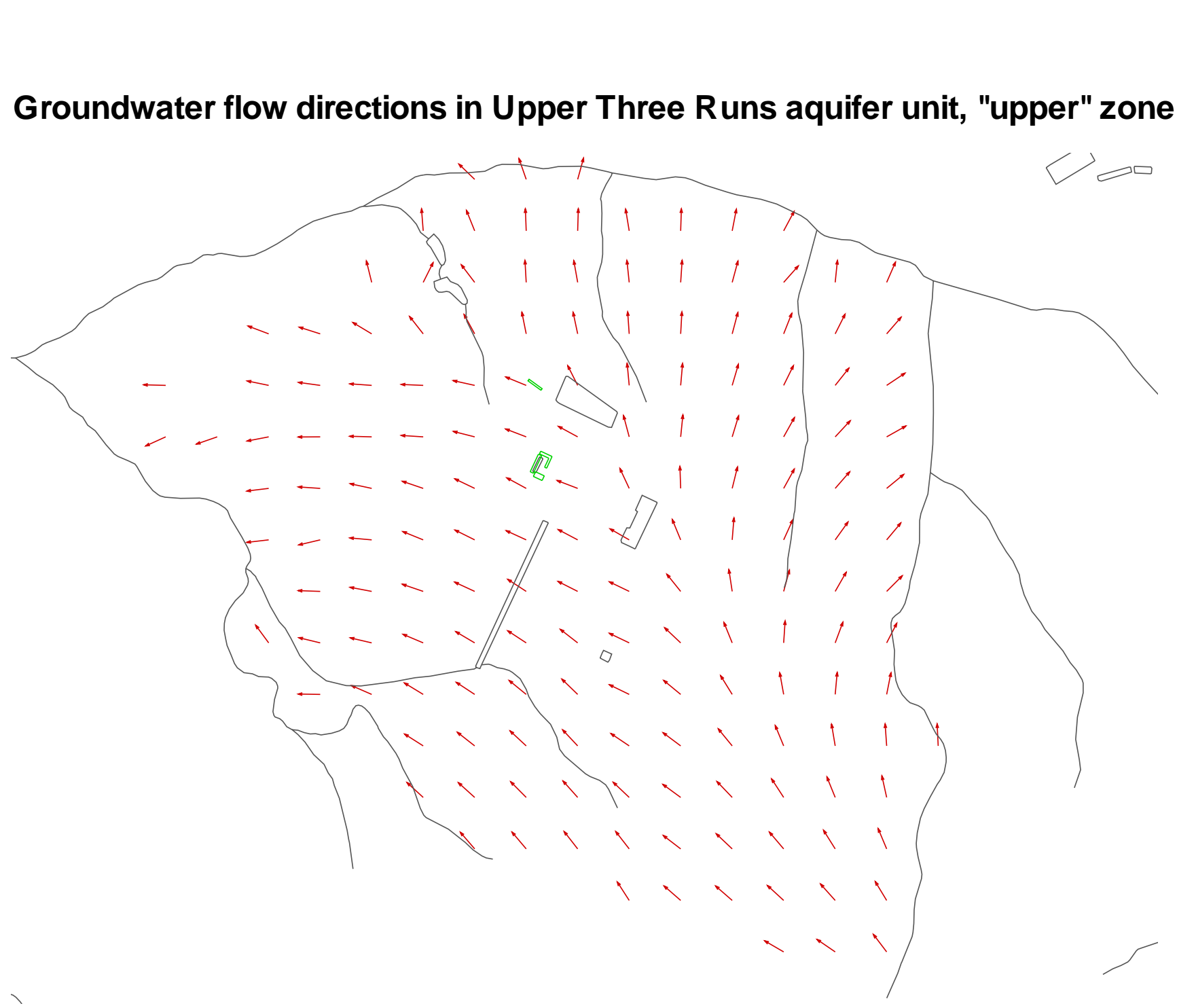

Figure 4-34. Simulated flow directions in the upper UTRA. 


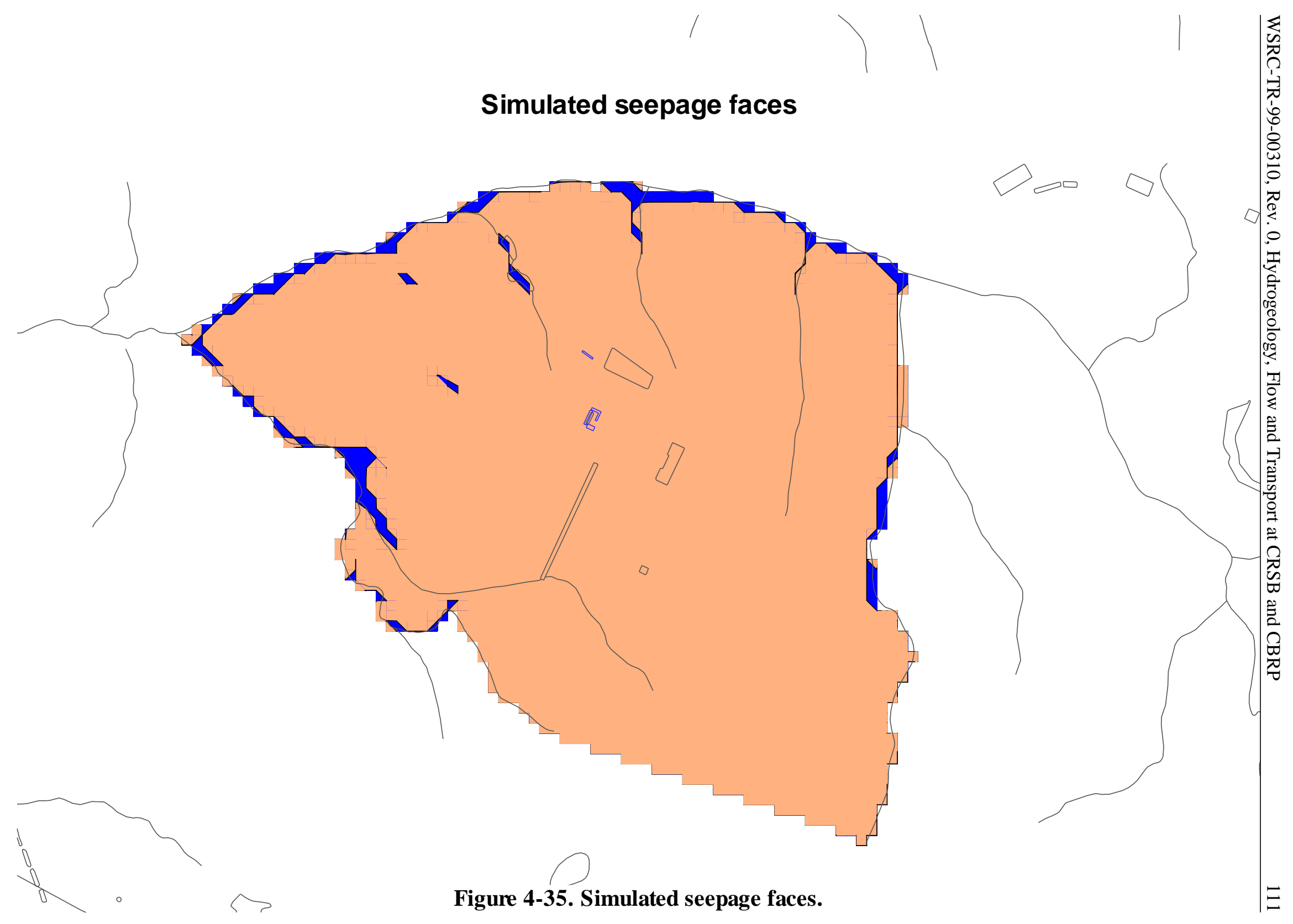




\section{Simulated groundwater recharge (discharge)}

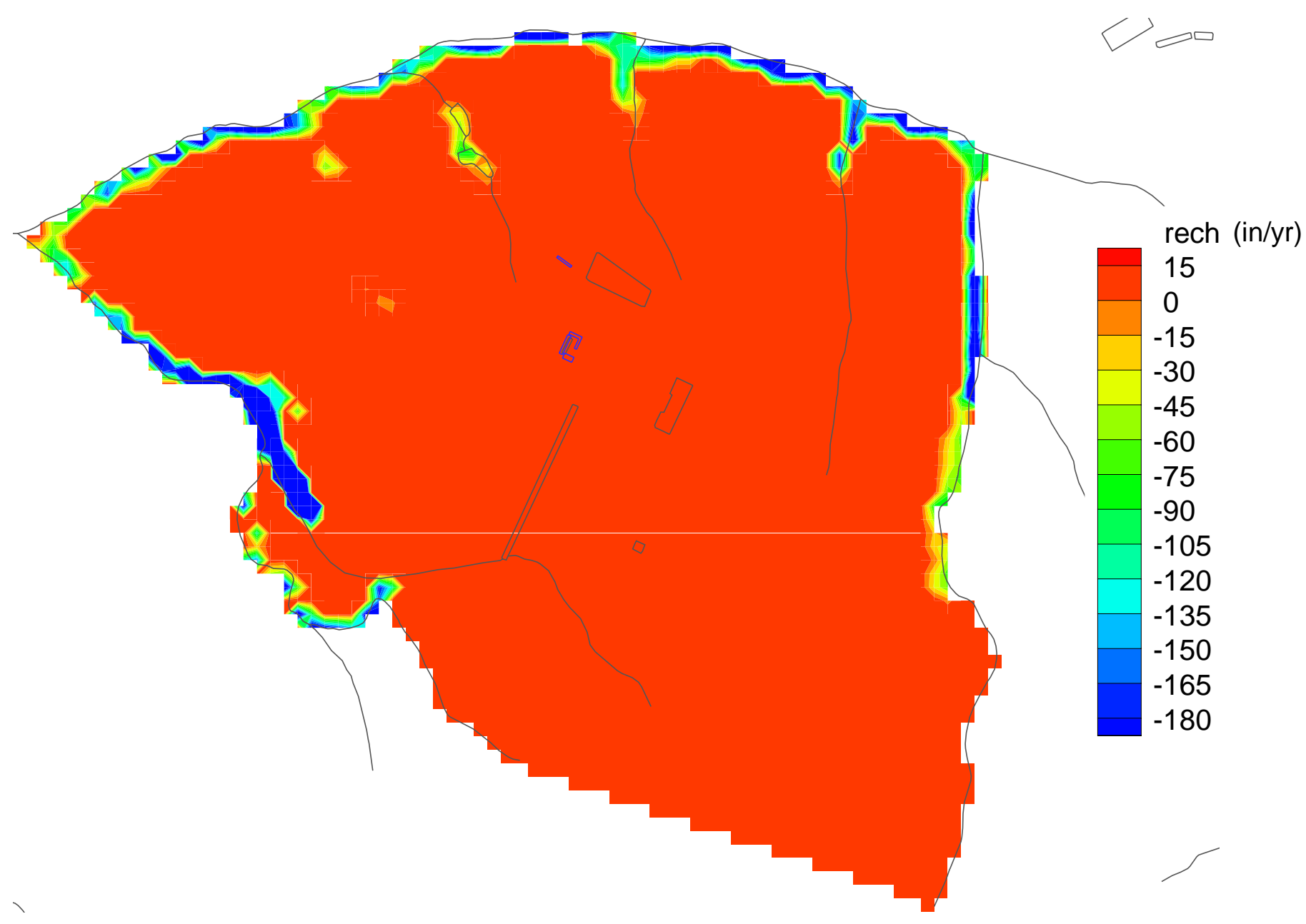

Figure 4-36. Simulated rates of recharge and discharge. 


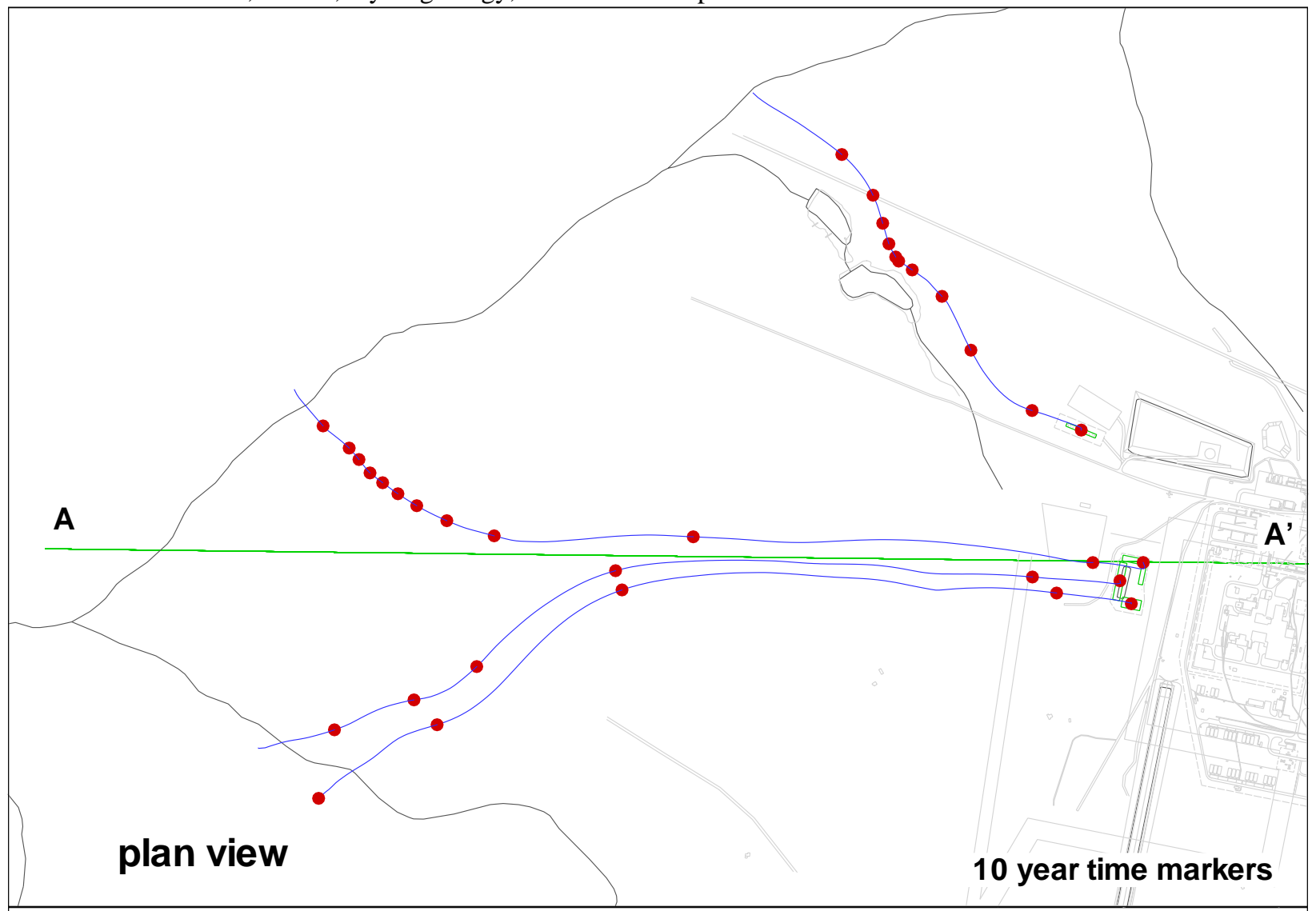

xsec view

10:1 vertical exaggeration

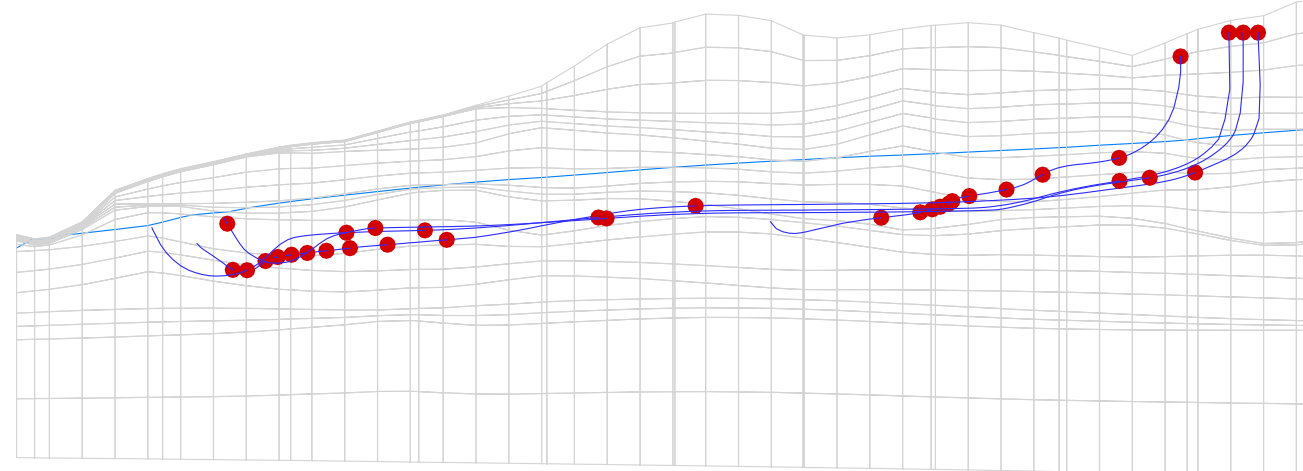

A

Figure 4-37. Simulated groundwater flow paths from the CRSB. 

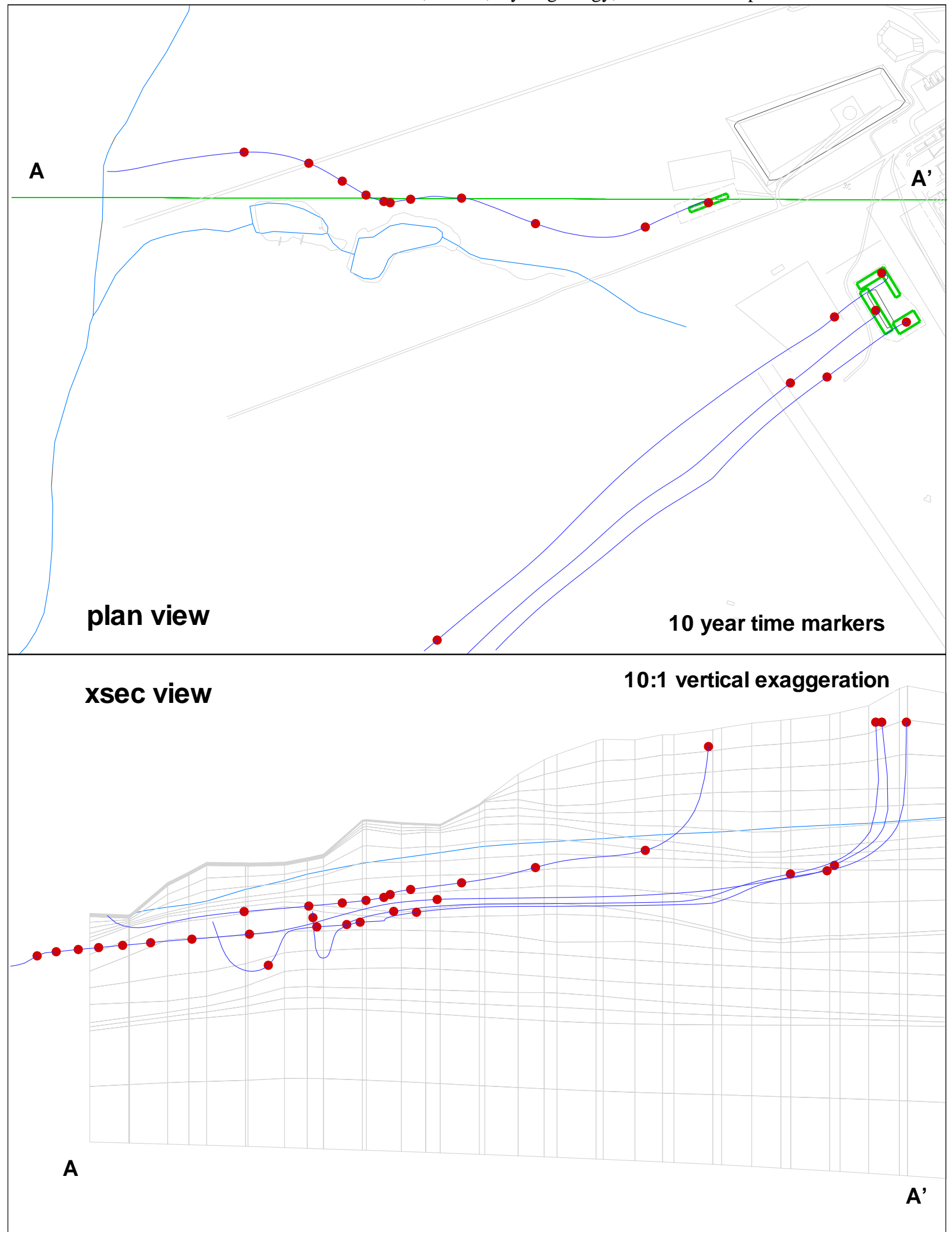

Figure 4-38. Simulated groundwater flow paths from the CBRP. 


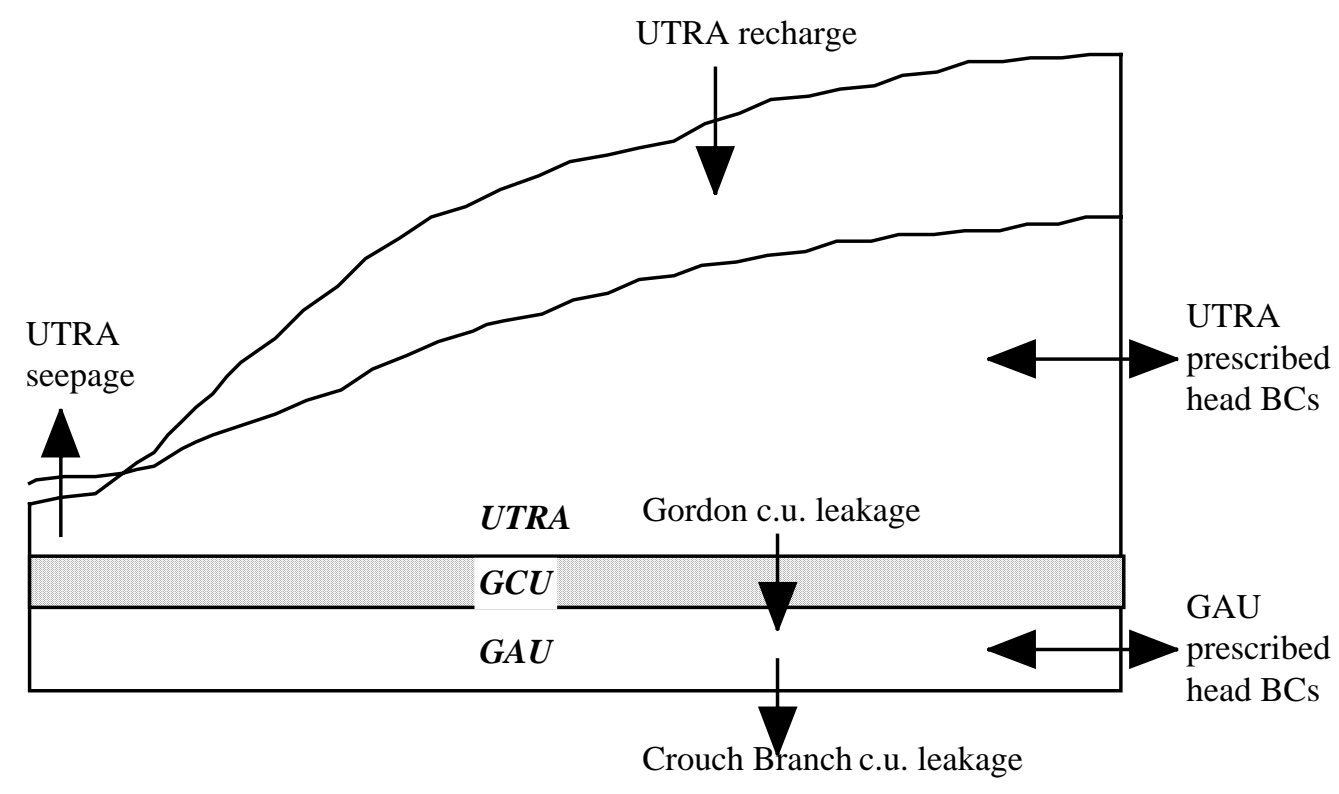

\begin{tabular}{lrrr}
\hline Flow component (cfs) & Entire model & UTR aquifer & Gordon aquifer \\
\hline Recharge & +3.6403 & +3.6403 & N/A \\
Seepage & -3.3292 & -3.3292 & N/A \\
Prescribed head BCs & -0.2191 & +0.3723 & -0.5915 \\
Gordon c.u. leakage & N/A & -0.6804 & +0.6804 \\
Meyers Br. c.s. leakage & -0.0860 & N/A & -0.0860 \\
Net total flow & $\mathbf{+ 0 . 0 0 6 0}$ & $\mathbf{+ 0 . 0 0 3 0}$ & $\mathbf{+ 0 . 0 0 2 9}$ \\
\hline
\end{tabular}

\section{4-39. Water Balance}


Table 4-1. Calibration Summary for Ground water Flow Targets

\begin{tabular}{|c|c|c|c|}
\hline Flow target & $\begin{array}{l}\text { Prior estimate } \\
\text { (cfs unless } \\
\text { otherwise noted) }\end{array}$ & $\begin{array}{l}\text { Range or } \\
\text { Uncertainty }\end{array}$ & $\begin{array}{c}\text { Model value } \\
\text { (in/yr for recharge; } \\
\mathrm{ft} 3 / \mathrm{s} \text { otherwise) }\end{array}$ \\
\hline Surface recharge & $15 \mathrm{in} / \mathrm{yr}$ & $10-16 \mathrm{in} / \mathrm{yr}$ & $\begin{array}{c}12.5 \text { max. local } \\
\left(\begin{array}{c}11.6 \text { based on total } \\
\text { area })\end{array}\right.\end{array}$ \\
\hline Caster Creek* & $2.9 / 2=1.45$ & - & $1.6(+10 \%)$ \\
\hline Creek south of Twin Lakes & 0.15 & - & 0.04 \\
\hline Twin Lakes creek & 0.19 & - & 0.05 \\
\hline Creek north of Twin Lakes & 0.15 & - & 0.06 \\
\hline $\begin{array}{l}\text { Creek south of Central } \\
\text { Shops outfall creek }\end{array}$ & 0.06 & - & 0.12 \\
\hline Central Shops outfall creek* & $0.76 / 2=0.38$ & - & $0.4(+5 \%)$ \\
\hline
\end{tabular}

* half of reach is within model domain 
Table 4-2. Calibration Summary for Hydraulic Head Targets

\begin{tabular}{|c|c|c|c|c|c|c|}
\hline $\begin{array}{c}\text { Measure } \\
(\mathbf{f t})\end{array}$ & $\begin{array}{c}\text { Gordon } \\
\text { aquifer }\end{array}$ & $\begin{array}{c}\text { "lower” } \\
\text { UTR } \\
\text { aquifer }\end{array}$ & $\begin{array}{c}\text { trans- } \\
\text { missive } \\
\text { zone }\end{array}$ & $\begin{array}{c}\text { AA } \\
\text { horizon }\end{array}$ & $\begin{array}{c}\text { A/uu } \\
\text { horizons }\end{array}$ & Overall \\
\hline $\begin{array}{c}\text { RMS } \\
\text { difference }\end{array}$ & 4.5 & 8.1 & 2.2 & 2.2 & 1.6 & 3.34 \\
\hline $\begin{array}{c}\text { Average } \\
\text { difference }\end{array}$ & -4.5 & -7.2 & -0.6 & -1.3 & 0.8 & 2.44 \\
\hline $\begin{array}{c}\text { Median } \\
\text { difference }\end{array}$ & -4.5 & -9.3 & -1.4 & -1.6 & +1.6 & - \\
\hline $\begin{array}{c}\text { Average } \\
\text { difference }\end{array}$ & 4.5 & 7.2 & 1.9 & 1.8 & 1.5 & - \\
\hline $\begin{array}{c}\text { Maximum } \\
\text { difference }\end{array}$ & -4.5 & -10.1 & +4.8 & -4.7 & -2.2 & - \\
\hline
\end{tabular}


Table 4-3. Calibration Summary for Hydraulic Conductivity

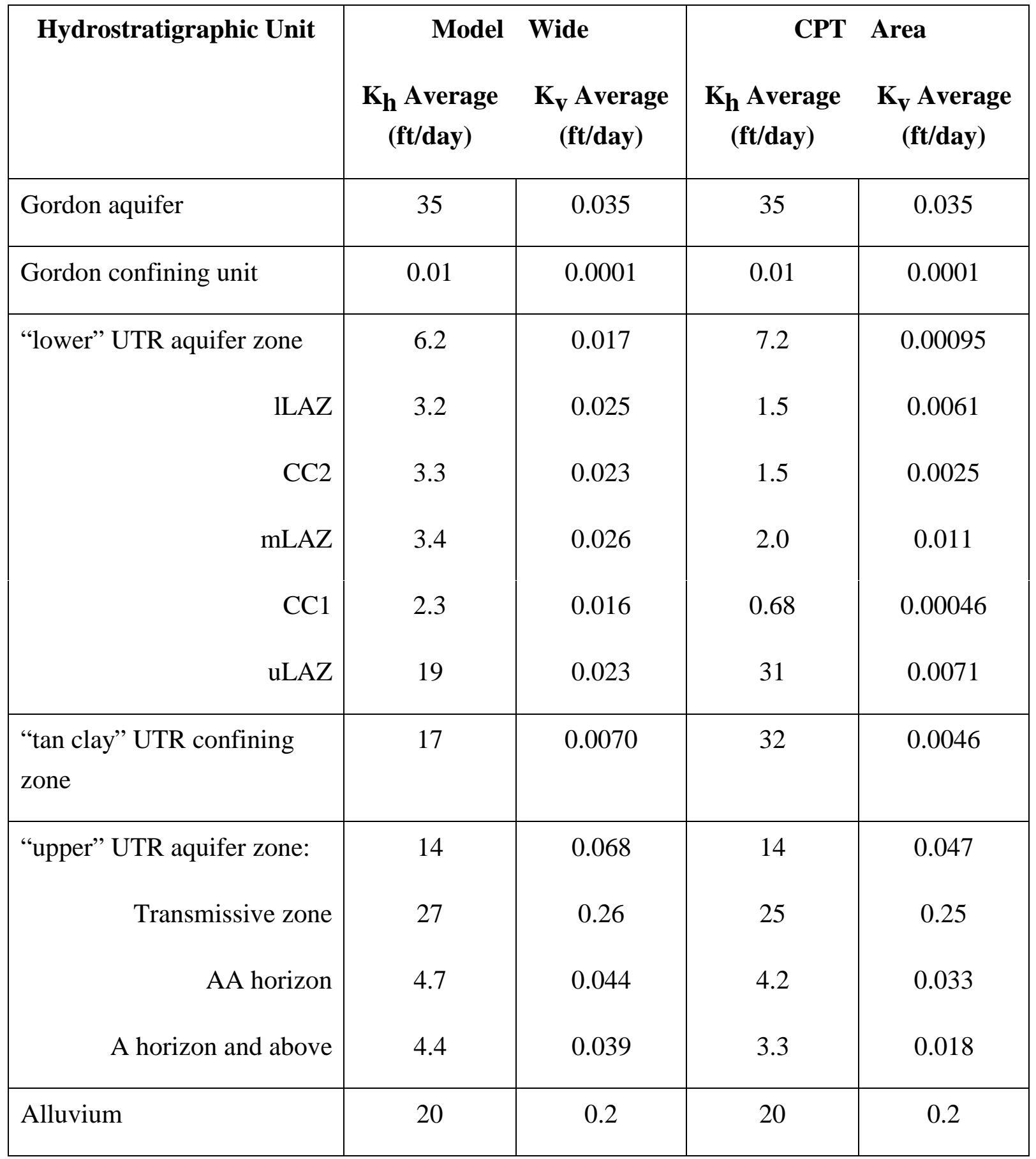




\subsection{CRSB AND CBRP FLOW AND TRANSPORT MODELS}

The C-Area groundwater flow model described in the previous two sections has a horizontal mesh resolution of $200 \mathrm{ft}$ (Figure 3-1). For transport simulations, higher mesh resolution in the horizontal plane is desirable to minimize numerical dispersion. Additional resolution (layers) in the vertical direction is also desirable, at least in the upper strata where contamination lies. Therefore, a second, higher-resolution, model will be developed for CRSB and CBRP transport simulations. Development of the CRSB and CBRP flow and transport model is described below, followed by transport simulation results for each facility.

\subsection{Model Development}

In order to keep the total number of grid blocks down to a feasible number, a smaller model domain is required for the CRSB/CBRP model to compensate for the higher grid resolution. An implication is that a smaller fraction of the model boundaries can be aligned with stream and more prescribed head boundary conditions will be needed. Fortunately this constraint is not an issue because the preceding C-Area flow model can be used to accurately define these boundary conditions, provided the models share the same underlying conceptual model and data.

The chosen domain and active mesh for the CRSB/CBRP model are illustrated in Figures 5-1 and 5-2. Based on the pathline analysis depicted in Figures 4-37 and 4-38, this domain is expected to encompass the entire CBRP and CRSB plumes through all time. Compared to the preceding C-Area model, the horizontal mesh size has been decreased from 200 to $100 \mathrm{ft}$. The vertical mesh contains the same total number of layers, but the distribution is different. The Gordon aquifer and confining units are represented with one model layer instead of two. The uLAZ interval now contains two elements, rather than one. The number of layers in the transmissive zone has been increased from 3 to 4 . The resolution of the other hydrostratigraphic intervals is unchanged.

Along Caster Creek and Fourmile Branch, recharge/drain boundary conditions discharge groundwater at the top nodal layer. No flow boundary conditions are applied beneath the two streams in the Upper Three Runs aquifer. Prescribed head boundary conditions are assigned to the entire Gordon aquifer, and those portions of the UTRA not beneath Caster Creek and Fourmile Branch. Head values are taken from the C-Area flow model. Material properties are assigned to the CRSB/CBRP mesh with the same methodology as was used for the preceding C-Area model. Therefore, the CRSB/CBRP hydraulic conductivity field is 
completely consistent with the C-Area model. Figure 5-3 shows simulated groundwater flow paths from the CRSB and CBRP. The simulated paths are practically the same as those shown in Figure 4-37.

Additional parameters are needed for CRSB and CBRP transport simulations. Based on the discussion in section 2.6.2, the porosity available for transport is assumed to effectively be $25 \%$. The longitudinal dispersivity in the horizontal plane was set to $50 \mathrm{ft}$. This setting is consistent with the rule of thumb that longitudinal dispersivity is approximately $10 \%$ of the plume travel length (Fetter, 1993, section 2.11). The selected dispersivity also corresponds to a grid cell Peclet number of 2 in the horizontal plane. The cell Peclet number less than or equal 2 is desirable in order to avoid excessive numerical dispersion (Huyakorn and Pinder, 1983). The dispersivity for transverse dispersion in the horizontal plane was initially set to $10 \%$ of the longitudinal dispersivity, or $5 \mathrm{ft}$ (Fetter, 1993, section 2.9). Dispersivities in the vertical direction were initially $0.5 \mathrm{ft}$. However, preliminary simulations produced too much dispersion and the dispersivities are currently assumed to be 10,1 and $0.1 \mathrm{ft}$. The time step size is set to 0.1 years, which generally results in a Courant number around 1 or less. Both contaminants of interest, tritium and TCE, are assumed to be unretarded. The first-order decay coefficient for tritium is defined such that the half-life is 12.3 years. TCE is assumed to not undergo first-order (e.g. biological) decay. Source terms for each facility are defined in the following sections.

\subsection{CRSB Transport}

Tritium releases to the C-Reactor Seepage Basins are documented in Environmental Protection Department (EPD) annual monitoring reports. Hetrick and Martin (1990) provide a summary listing through 1988, which covers the time span over which the basins were active. Figure 5-4 illustrates tritium releases to the CRSB, and the nearby C-04 outfall / CArea canal. Although significantly more tritium activity was discharged to the C-04 outfall, the concentration would have been very low due to high process water flows at the time. As shown in Figure 5-5, process water flows when C-Reactor was operating (and significant tritium releases occurred) would have been on the order of $400 \mathrm{cfs}$. For example, an annual release of $15000 \mathrm{Ci}$ corresponds to an average concentration of about $40 \mathrm{pCi} / \mathrm{ml}$. Considering radioactive decay since the mid-1980's, present concentrations would be around $20 \mathrm{pCi} / \mathrm{ml}$ (tritium has a half-life of 12.3 years). Therefore, the C-canal is an unlikely contributor to the higher concentration plume detected with recent CPT sampling (Appendix C). Pathline analysis further supports this conclusion. The possibility of upgradient moderator spills or other high concentration tritium releases from the $105-\mathrm{C}$ reactor building 
as co-mingling sources for the present plume has not been investigated in this study. Transport modeling will be performed only for the known tritium releases to the CRSB shown in Figure 5-4.

Figure 5-6 shows a three-dimensional cutaway view of the simulated tritium plume emanating from the CRSB in early 1999. The floor of the cutaway follows nodal layer 11, which is the bottom of the transmissive zone except where the unit crops out. Plan and crosssectional views of the three-dimensional simulated plume are shown in Figure 5-7. The bulk of the plume discharges to Caster Creek, consistent with the simulated groundwater pathlines shown in Figure 5-3 and CPT data in Figure G-1. The plume travels mainly in aquifer zones above $\mathrm{CC} 1$, which is a competent confining zone in the area (Figures 4.14, G-35). The highest seepline concentrations are about $2000 \mathrm{pCi} / \mathrm{ml}, 100$ times higher than the MCL for tritium $(20 \mathrm{pCi} / \mathrm{ml})$. The maximum concentration anywhere in the simulated plume is shown in Figure 5-8 as a function of time. The peak concentration at the beginning of 1999 is $43,000 \mathrm{pCi} / \mathrm{ml}$, which compares favorably with the maximum measured concentration of $58,000 \mathrm{pCi} / \mathrm{ml}$ at the CRSB.

Figure 5-9 shows simulated tritium concentration vertically averaged between the water table and CC1. The CPT locations shown in the figure were selected for the purpose of comparing model predictions to field data. From inspection of the raw CPT data, locations CRSB-47 and CRSB-116 through CRSB-121 appear to intercept the center of the actual plume in plan view. For each of these locations, Table 5-1 identifies the vertical interval spanning the plume center and the average measured concentration. The actual plume appears to be about $25 \mathrm{ft}$ thick in this area with an average concentration of roughly $5000 \mathrm{pCi} / \mathrm{ml}$. The simulated plume in Figure 5-9 exhibits similar concentrations at the same distance from the source. However, it should be noted that the vertical averages at locations CRSB-47 and CRSB-116 through CRSB-121 span a larger thickness ranging from 35 to $50 \mathrm{ft}$. Nearing the seepline at Caster Creek, the highest concentrations were measured at CRSB-122, CRSB-123, CRSB108 and CSB-66A. The average concentration over the intervals considered in Table 5-1 is about $1500 \mathrm{pCi} / \mathrm{ml}$. Simulated concentrations in the same general area are similar in magnitude. CPT locations CSB-58 through 62A are located along the fringe of the simulated plume. The actual plume concentration averages about $1700 \mathrm{pCi} / \mathrm{ml}$ in this area over a 10 to $15 \mathrm{ft}$ thickness. The simulated concentrations shown in Figure 5-9 are similar. However, these are vertical averages over a 20 to $30 \mathrm{ft}$ thickness, compared to half as much for the measured data in Table 5-1. 
Figure 5-10 shows historical plume development through a sequence of vertically-averaged concentrations between the water table and $\mathrm{CC} 1$, similar to Figure 5-9. Figure 5-11 shows future plume migration through 2035, as predicted by the model. Seepline concentrations above MCL will be observed for decades according to the model predictions. Unfortunately, the decline in tritium concentrations depicted in Figure 5-11 is likely to be overpredicted by the current model. Single-porosity models typically underpredict the tails of a contaminant plume (e.g. Gelhar, 1993, Figure 5.11).

The migration path and concentration levels of the predicted 1999 tritium plume appear to agree well with the CPT data as a whole, considering data variability and gaps. However, the simulated plume is thicker in the vertical dimension than the actual plume. The lateral extent of the plume appears to be somewhat overestimated too. This may be a result of excessive numerical dispersion, and/or the source being distributed over too large of an area. Reducing the plume volume through model refinements would result in higher predicted concentrations. Additional modifications would be anticipated to bring predicted concentrations in line with the 1999 CPT data. Considering that the source term is relatively well known, candidate model improvements within the current framework would include modifying plume travel times through changes to conductivities, effective porosity and/or dispersivities. The above model biases should be reduced before a formal uncertainty analysis is conducted.

Alternatively, a dual porosity approach could be employed to reduce simulated 1999 concentrations by better accounting for aquifer heterogeneities and the resulting wide range of groundwater velocities. The approach can also be expected to improve predictions of long-term plume migration. A dual porosity formulation is recommended for future CRSB transport modeling. In a dual porosity formulation, the total porosity in each model grid block is partitioned into a mobile (effective) and immobile porosity. The former corresponds to sandy, transmissive sediment, and the latter to fine-grained material of comparatively low conductivity. In the early stages of plume migration or at the leading edge, concentrations are higher in the mobile porosity and lower in the immobile porosity compared to a single porosity model. Contaminant slowly diffuses into the immobile region (clay) from the mobile region (sand) in this stage. In the later stages of plume migration or at the back end, concentrations decrease in the mobile region. Concentrations are higher in the immobile region (clay), and contaminant now diffuses back into the mobile porosity (sand). In other words, after the plume centroid passes, contamination "leaches" out of the immobile porosity (clay) into the mobile porosity (sand), thus creating lower peak concentrations but longer 
(heavy) plume tails. Lower peak concentrations in the mobile porosity that is typically sampled by CPT would likely improve CRSB model predictions for 1999. The phenomenon described above was observed at the SRS Old Burial Ground during sediment coring programs conducted in 1979-80, 1982 and 1985 (Orebaugh, 1987). The highest tritium concentrations were frequently observed in the lower conductivity intervals.

\subsection{CBRP Transport}

The C-Area Burning/Rubble Pit was constructed in 1951 and used to dispose of and burn organic solvents, waste oils, paper, plastics, and rubber through 1973. CPT sampling in 1999 detected high TCE concentrations in groundwater beneath and downgradient of the waste unit (Appendix C). Beneath the CBRP, the highest measured concentration was 130,000 ppb $(\mu \mathrm{g} / \mathrm{L})$ at 131C-R10. Downgradient, concentrations in the 100's to 1000's of ppb were frequently observed. At the lower of the Twin Lakes, a concentration of $7900 \mathrm{ppb}$ was measured at 131C-81. The fact that large volumes of organic solvents were disposed of in the pit and the persistence of high TCE concentrations 25 years after burning ceased suggests that the vadose zone beneath the CBRP contains some NAPL. The solubility of TCE is about $1,100,000$ ppb so NAPL would create a long-term source of high, and relatively constant, TCE concentration at the water table beneath the CBRP. Planned Soil Vapor Extraction (SVE) in the vadose zone and Air Sparing (AS) in the saturated zone will greatly deplete the source in the near future.

Following these concepts, the TCE source term can be approximately modeled as a constant flux to the vadose zone from 1951 to present (1999), and no future source. SVE/AS operations will leave some residual contamination in the vadose zone after active remediation, mainly in fine-grain sediment. The contamination will diffuse out of the finegrain material, and recontaminate surrounding sandy sediment. This phenomena has been referred to as a "rebound effect". The amount of residual contamination that will remain after SVE/AS operations cease is uncertain. The Consortium for Risk Evaluation with Stakeholder Participation (CRESP) is currently investigating SVE/AS remediation at the CBRP through analysis of operations data and fundamental modeling. The results of this effort and SVE/AS operating data will be valuable in the long-term. For the present effort, $\mathrm{SVE} / \mathrm{AS}$ operations are assumed to remove all NAPL but not reduce solute concentrations at the source. This assumption is likely to be conservative with respect to predictions of future migration. The magnitude of the flux was estimated through model calibration to be roughly $10 \mathrm{~kg} / \mathrm{yr}$, in order to achieve concentration levels similar to the CPT data. This corresponds to a NAPL area of $300 \mathrm{ft}^{2}$, or $3.5 \%$ of the pit area. 
Figure 5-12 illustrates the simulated TCE plume from the CBRP in early 1999. The floor of the cutaway follows nodal layer 11 , which is the bottom of the transmissive zone. The vertical cut passes through the upper part of Twin Lakes. The simulated plume is observed to discharge to Twin Lakes consistent with field data. Centerline concentrations at this point peak at about $500 \mathrm{ppb}(\mu \mathrm{g} / \mathrm{L})$. Figure 5-13 shows plan and cross-sectional views of the threedimensional plume. The plume travels mainly in hydrostratigraphic zones above $\mathrm{CC} 1$ and discharges to both Twin Lakes and Fourmile Branch. The migration path of the main plume is consistent with CPT data (Figure G-2), in that it parallels the Twin Lakes drainage on the north side. The extent of the calculated plume is greater than observed, especially with respect to the lobe passing south of the Twin Lakes drainage. The southern lobe is created in the model by a high conductivity zone starting near the CBRP and stretching to Caster Creek and Fourmile Branch (Figures 4-15 through 4-20, G-36, G-38, G-40, G-42 and G-44). The feature is not observed in the actual plume based on CPT concentration data (Figure G-2). The maximum predicted concentration anywhere in the plume is shown in Figure 5-14. In 1999 , the peak concentration is nearly $12,000 \mathrm{ppb}$. Source zone concentrations measured with CPT vary greatly and at a smaller scale than the effective model resolution, making a direct comparison difficult.

Figure 5-15 illustrates vertically-averaged concentration between the water table and CC1 for the simulated plume in early 1999. Predicted concentration levels for portion of the plume migrating past Twin Lakes appear to be consistent with the CPT data listed in Appendix C. Immediately down-gradient of the source zone, predicted concentrations are several hundred ppb. In the Twin Lakes area, concentrations are on the order of $100 \mathrm{ppb}$. Historical plume development is depicted in Figure 5-16. The simulated plume has essentially reached a steady-state configuration by 1999 as a result of applying a constant TCE source from 1951 through present. No additional TCE is added to the source zone after 2000, and plume concentrations decline as shown in Figure 5-17. Predicted concentrations remain well above MCL (5 ppb) for decades into the future. Recalling that SVE/AS operations are assumed to remove all NAPL but not reduce solute concentrations at the source, these predictions are probably conservative. On the other hand, single porosity transport models such as the present typically underestimate the plume tail, a non-conservatism.

A number of model refinements are recommended for future CBRP modeling. The conductivity field should be modified to eliminate TCE migration to the south side of the Twin Lakes drainage. The vertical and horizon extent of the plume should be decreased by reducing numerical dispersion, and confining the source area to the actual CBRP (the current 
model has a broader source zone). Following these adjustments, the source term should be recalibrated to match CPT data. Additional interpretation of the CPT data and hand-drawn plume cross-sections are recommended to aid model calibration. The amount of residual contamination remaining after SVE/AS operations should quantitatively estimated, hopefully based on the CRESP effort. A dual porosity formulation is recommended in order to better model rebound phenomena in vadose and saturated zones, and heavy plume tailing. The suggested model refinements should completed in order to reduce model biases before a formal uncertainty analysis is conducted. 


\section{Active Mesh Elements of CRSB and CBRP Flow and Transport Model}

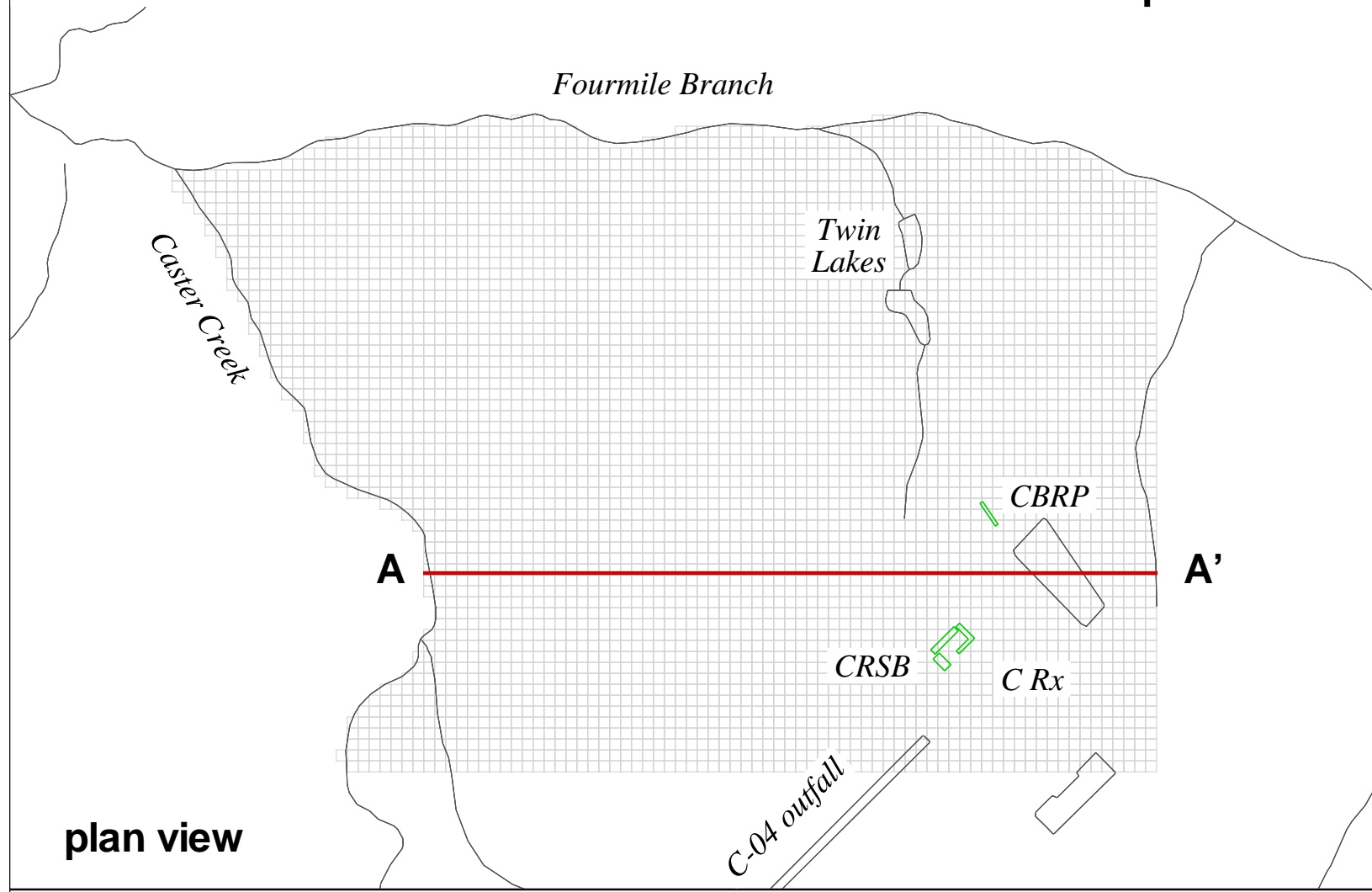

xsec view

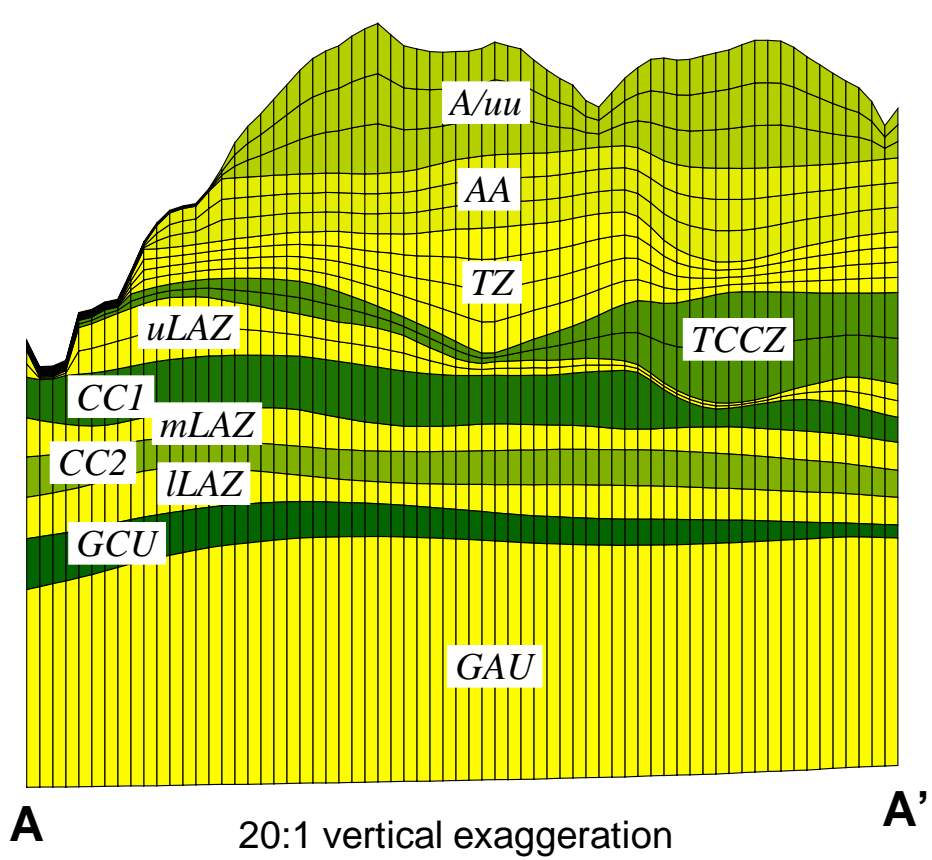

Figure 5-1. Plan view of CRSB/CBRP model domain and finite-element mesh. 


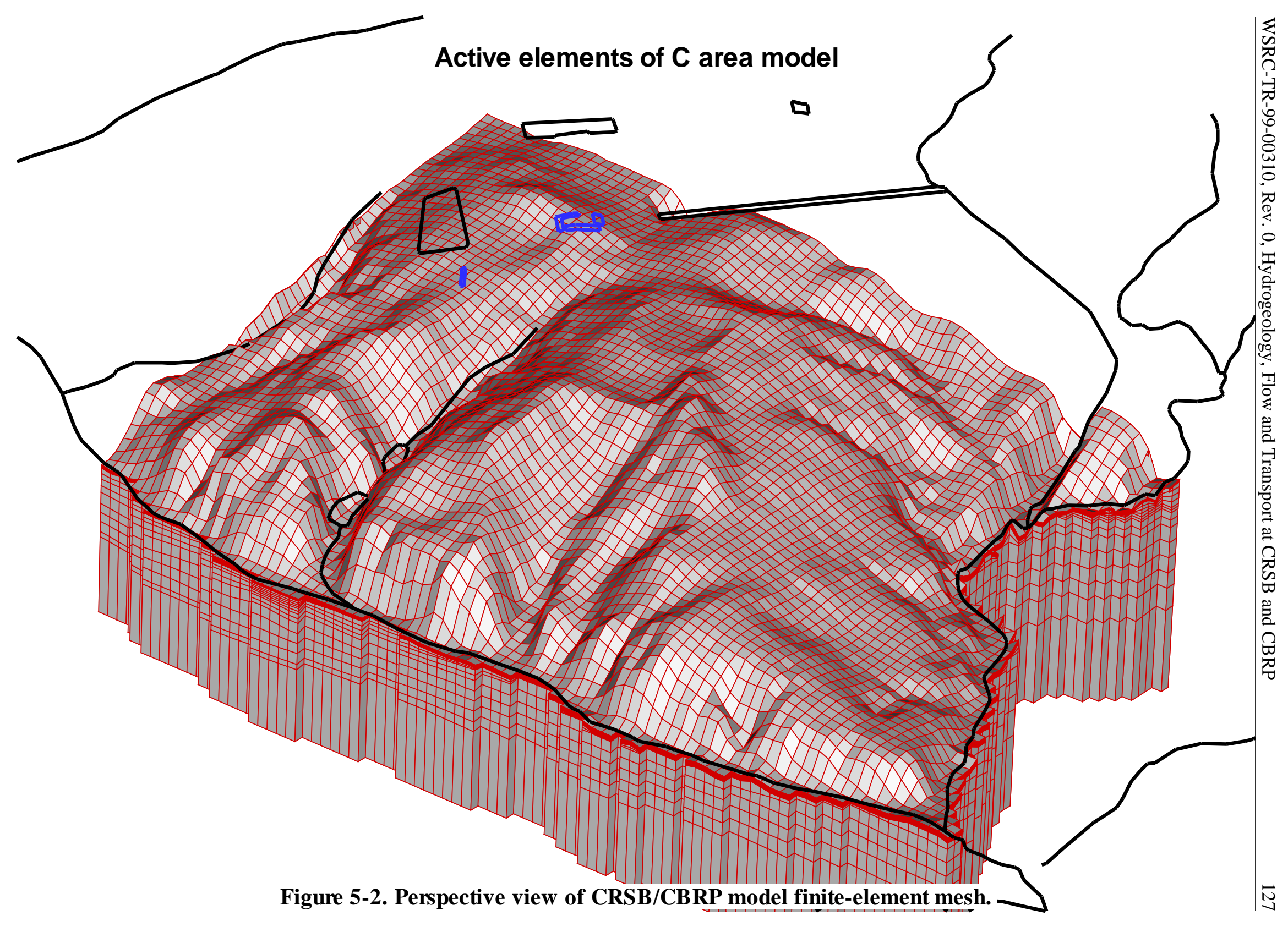



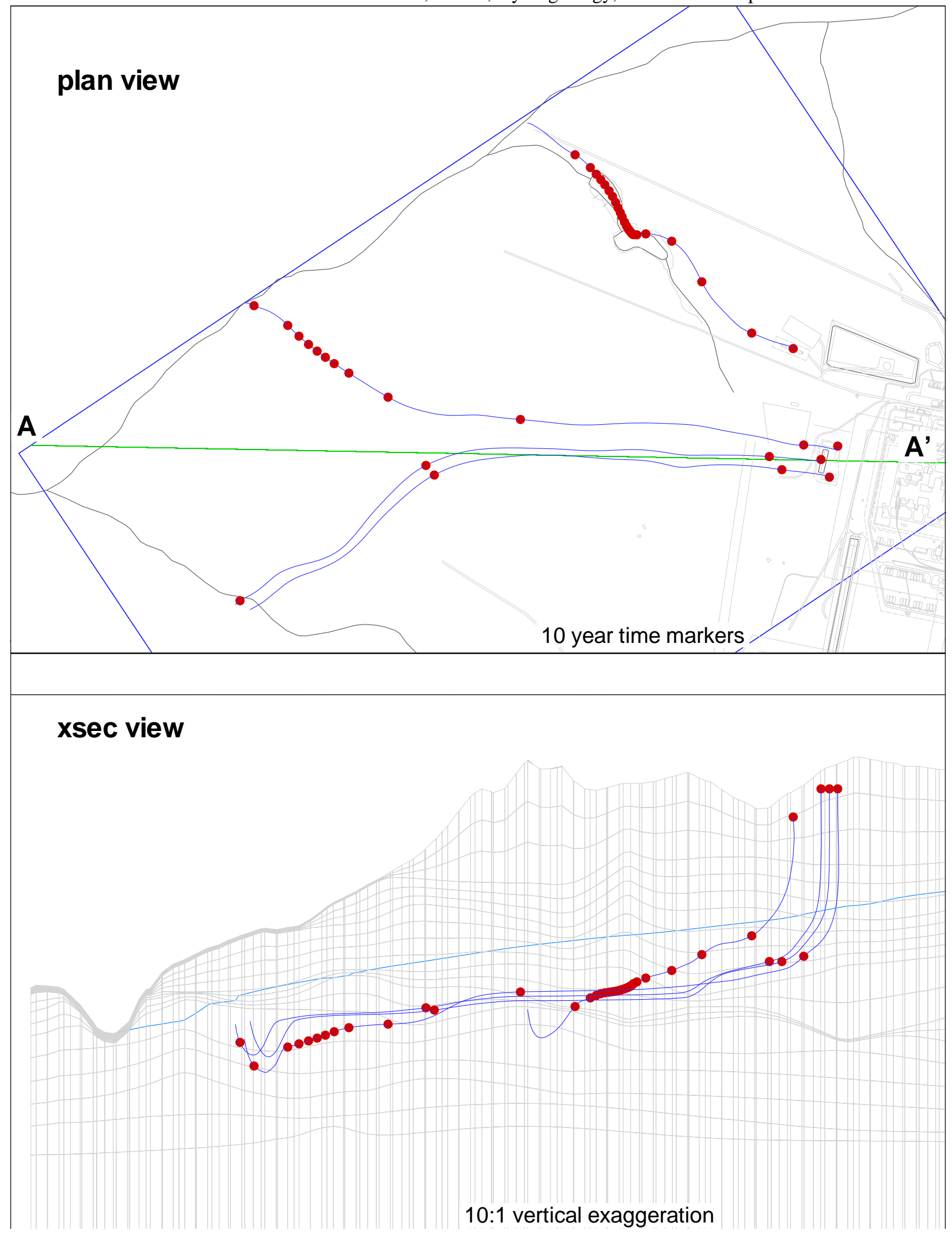

Figure 5-3. Simulated groundwater flow paths from the CRSB and CBRP. 


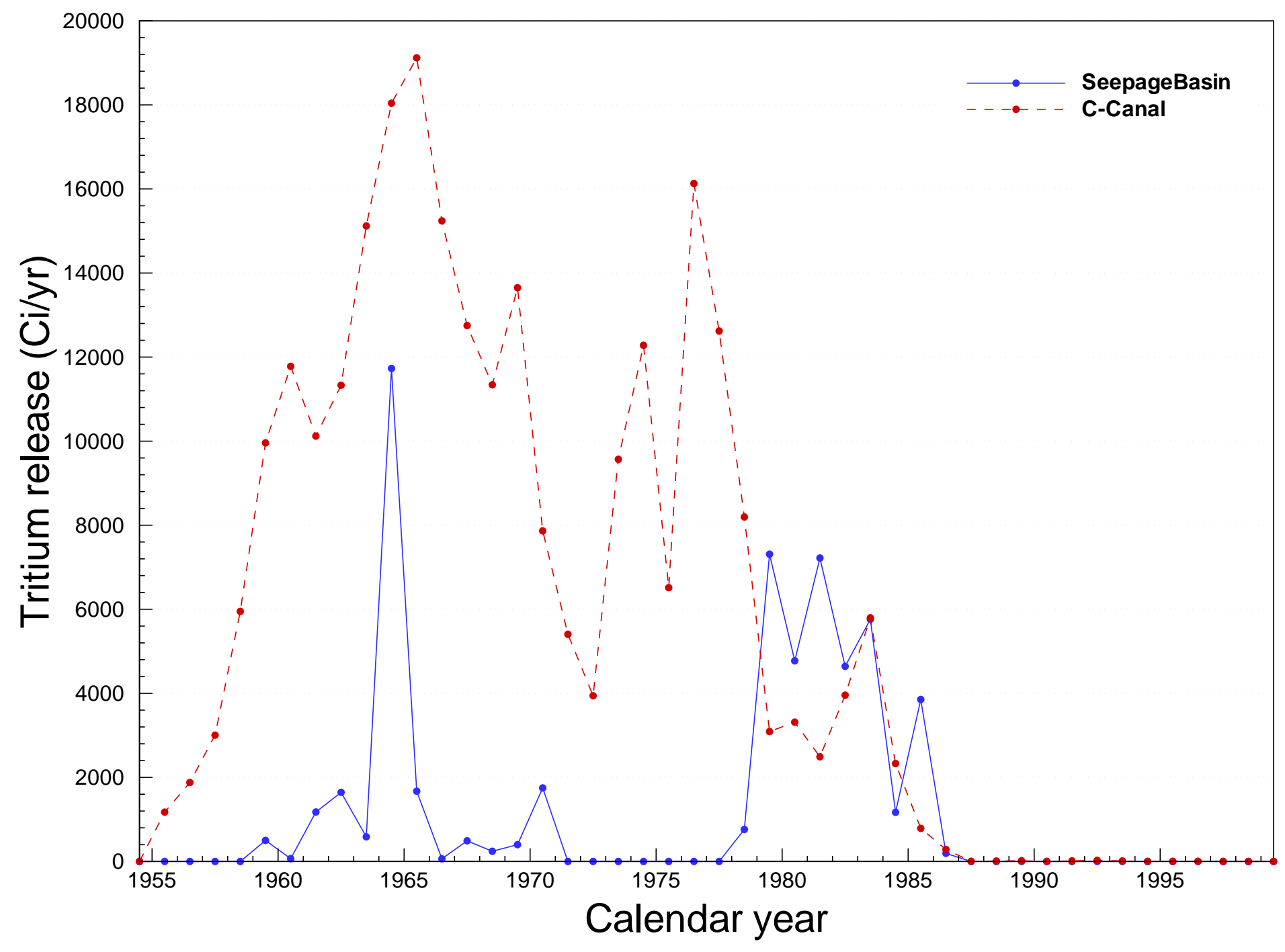

Figure 5-4. Tritium releases to the $\mathrm{C}$-Reactor Seepage Basins. 


\section{6 / C-04}

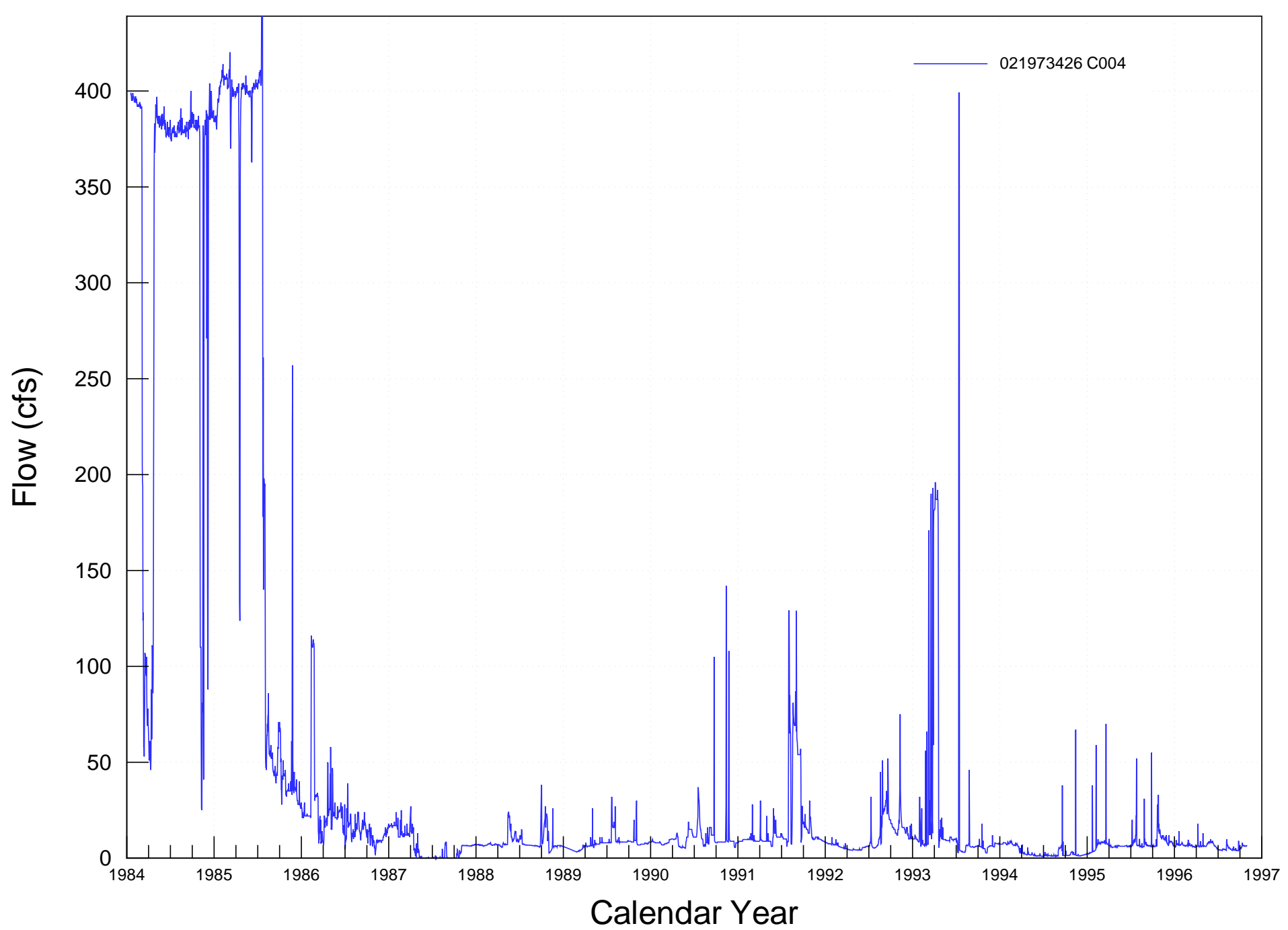

Figure 5-5. Process water discharge to $\mathrm{C}-04$ outfall and C-area canal. 


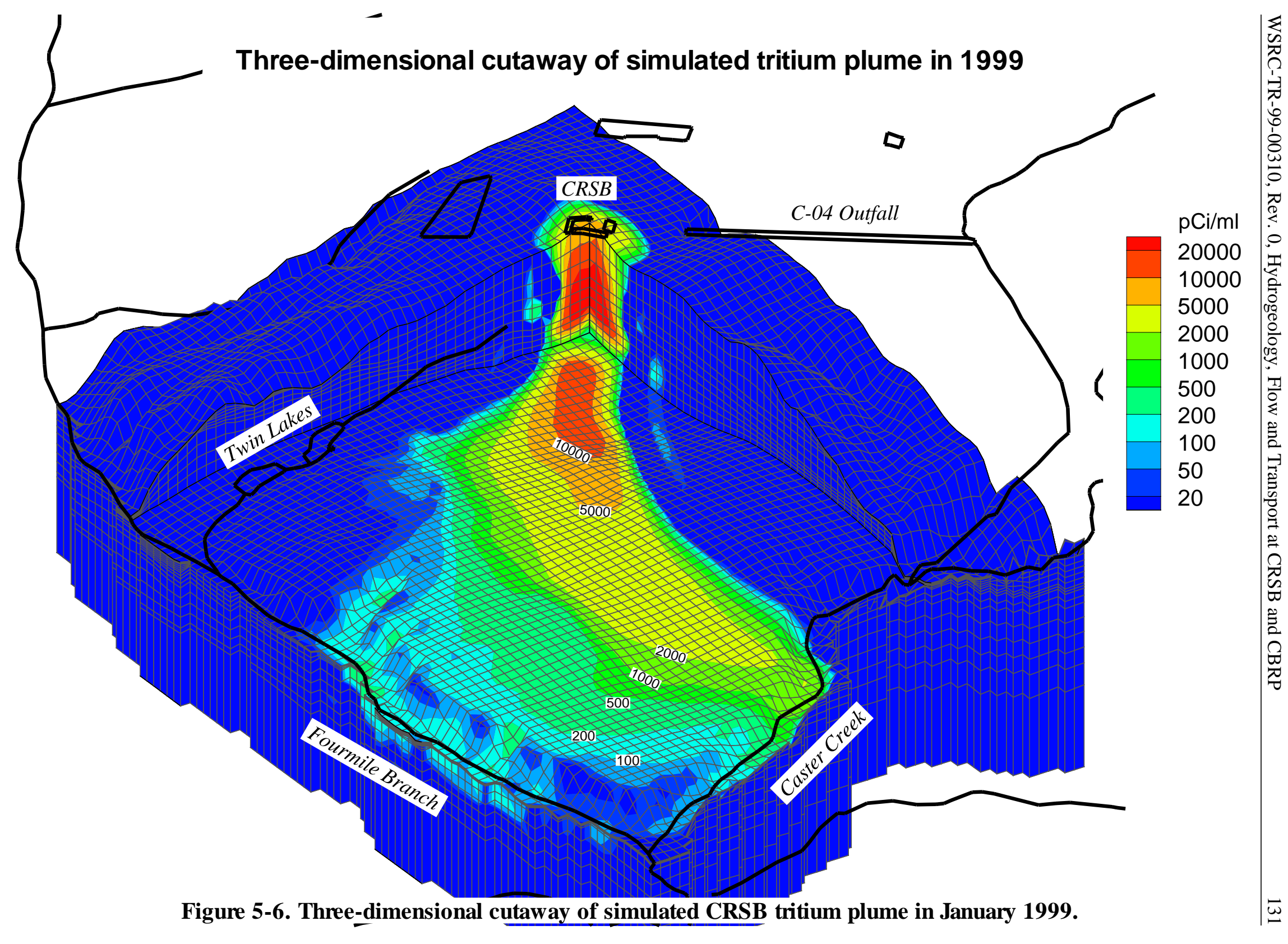




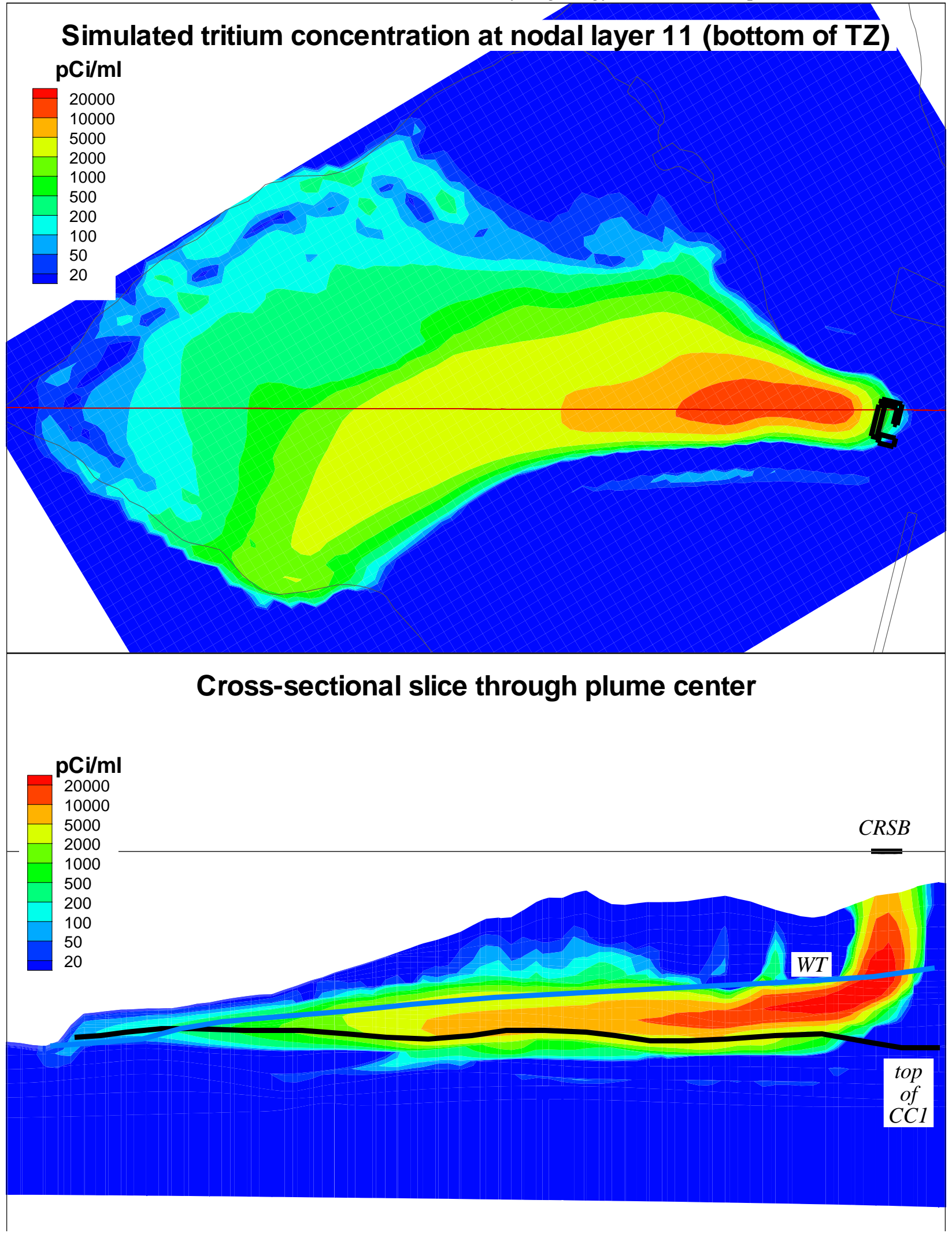

Figure 5-7. Plan and cross-sectional views of simulated CRSB tritium plume in Jan. 1999. 


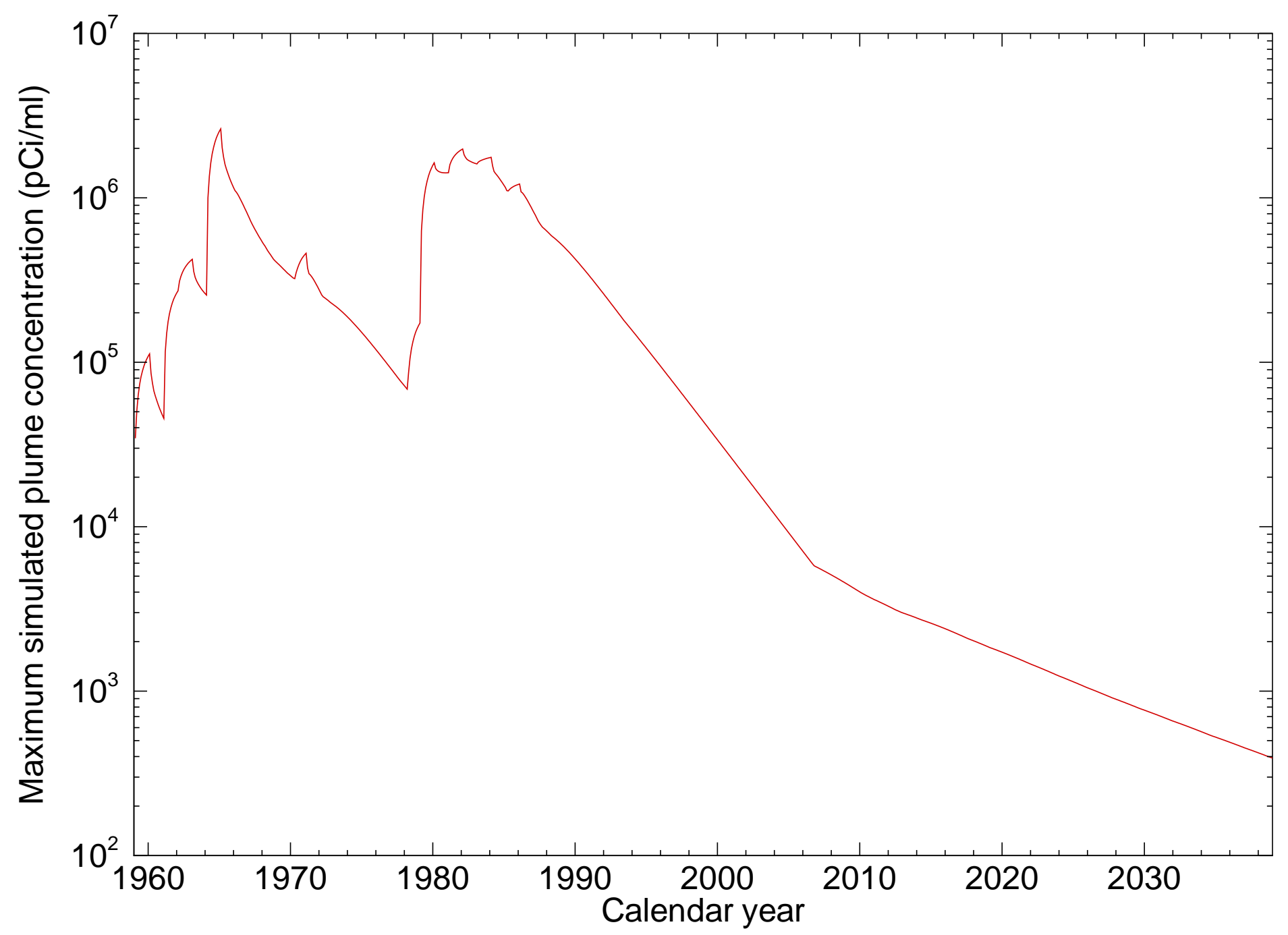

Figure 5-8. Maximum concentration in simulated CRSB tritium plume through time. 
Vertically-averaged simulated tritium concentration above CC1

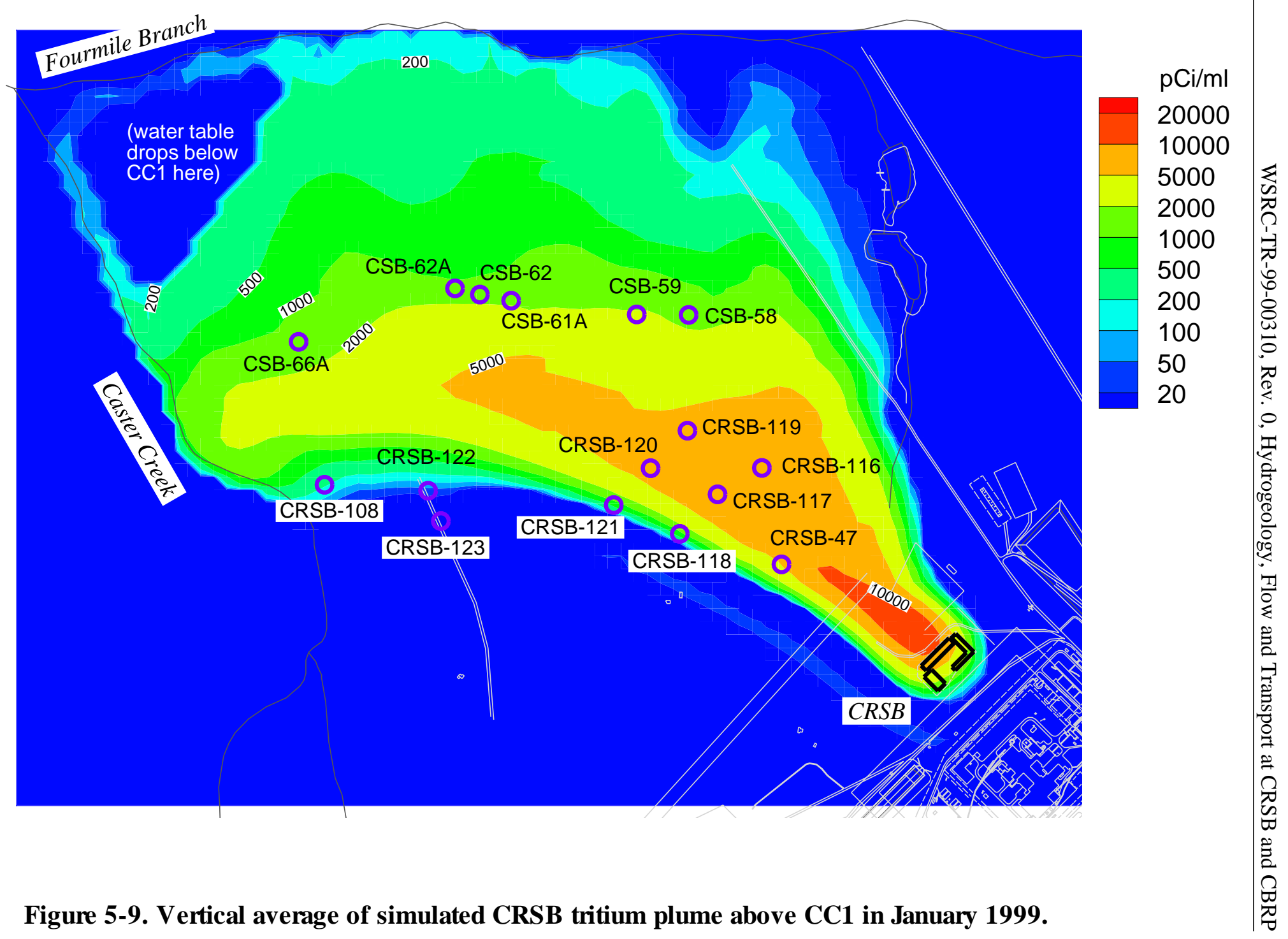




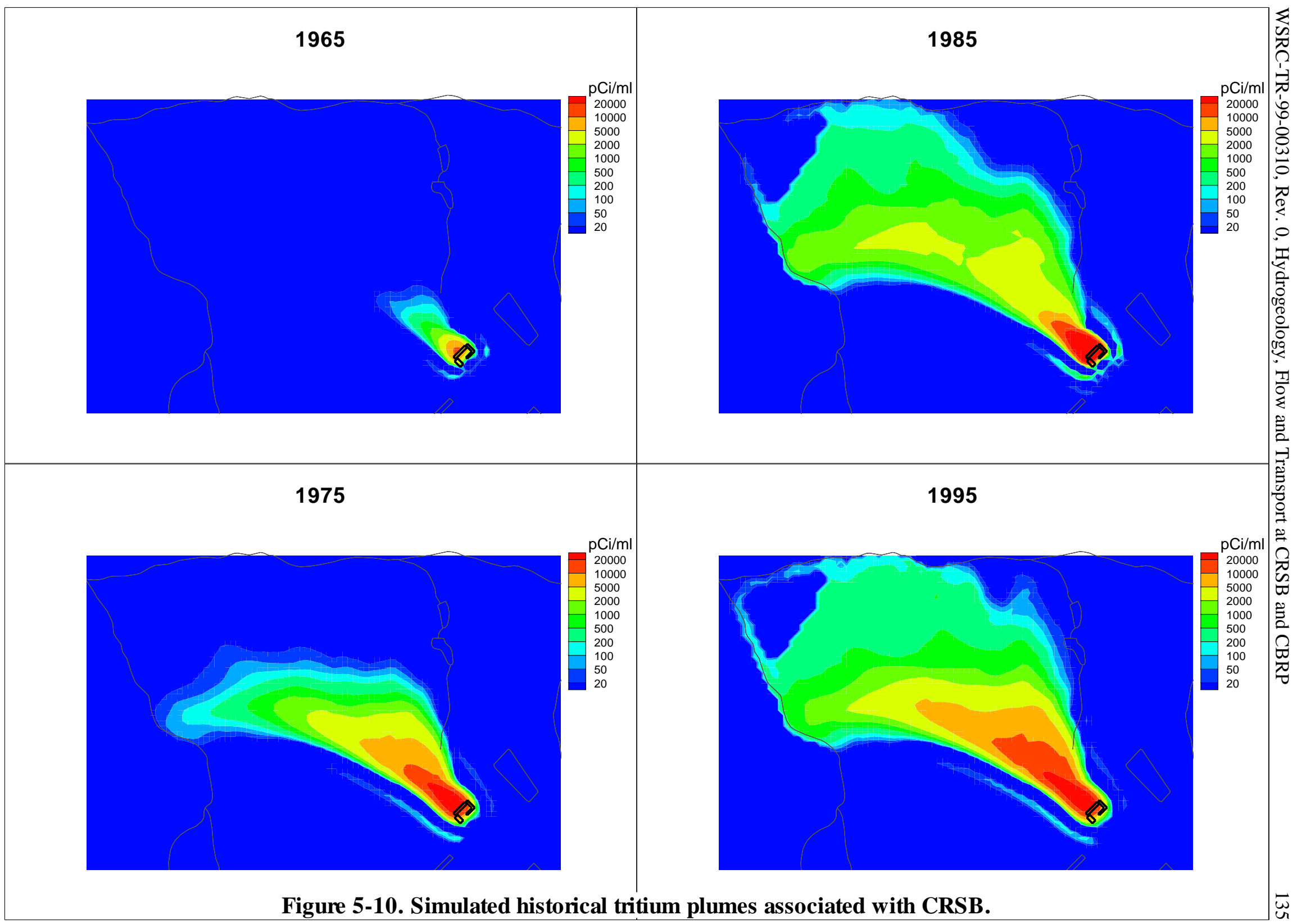




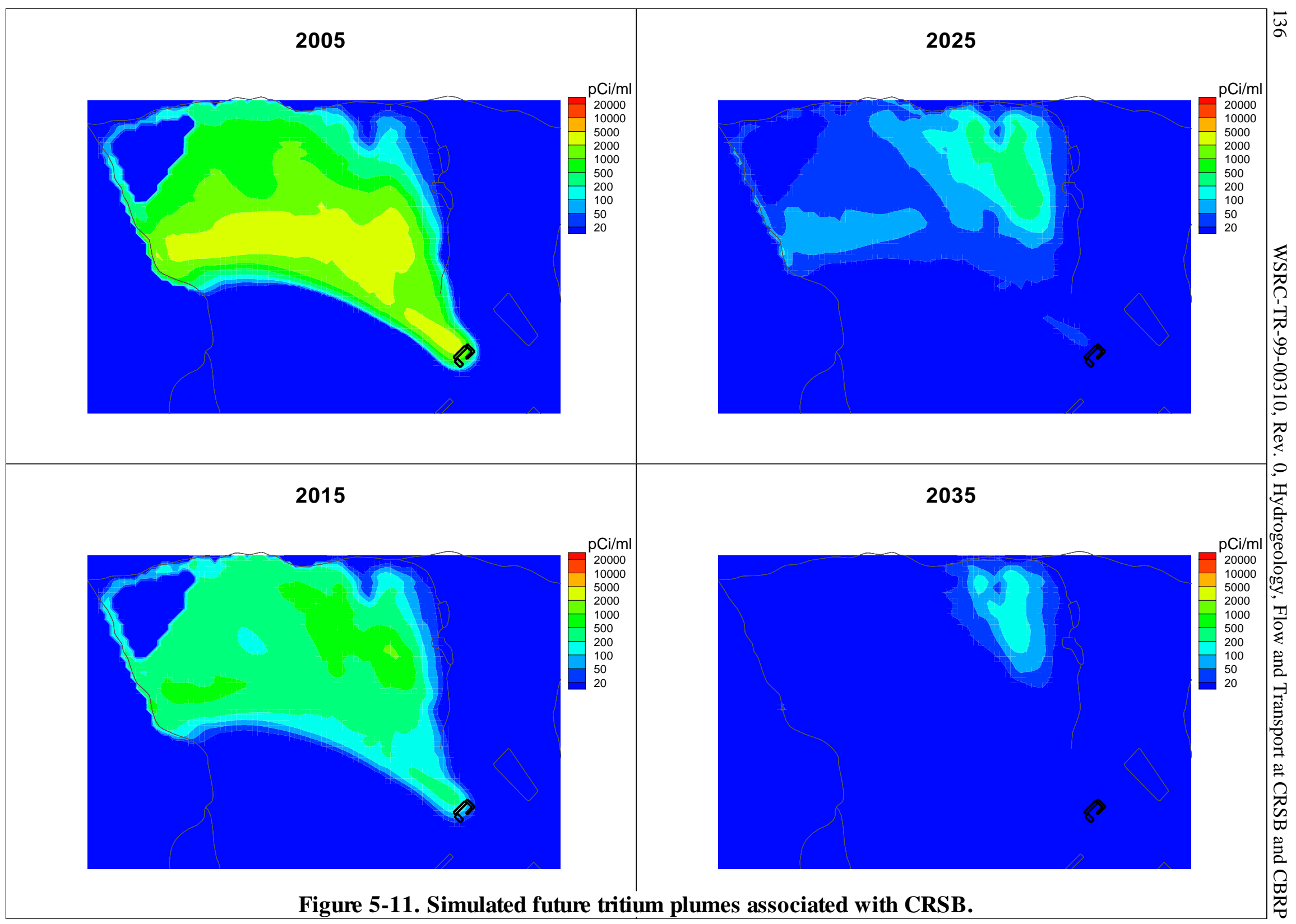




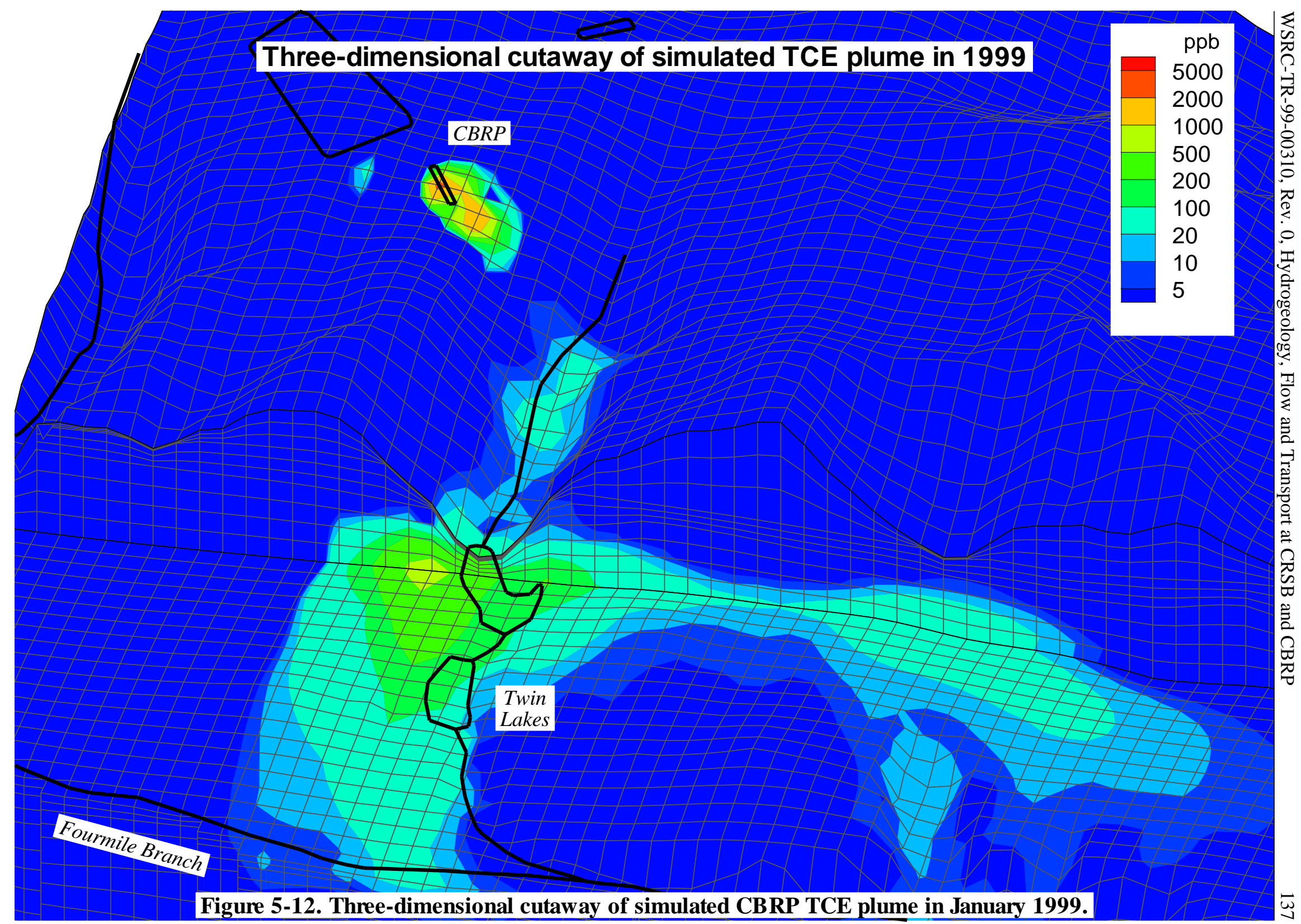




\section{Simulated TCE concentration at nodal layer 11 (bottom of TZ)}
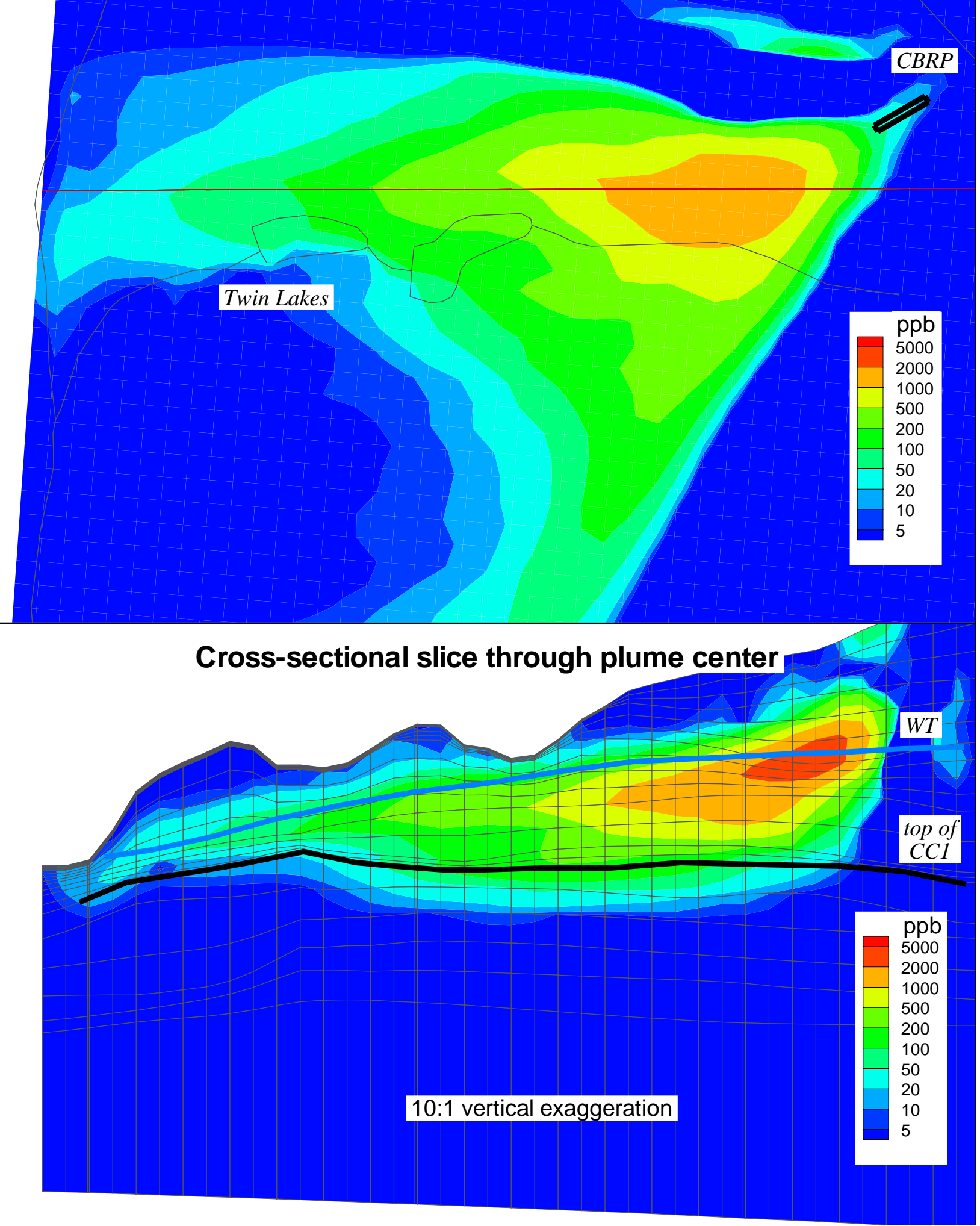

Figure 5-13. Plan and cross-sectional views of simulated CBRP TCE plume in Jan. 1999. 


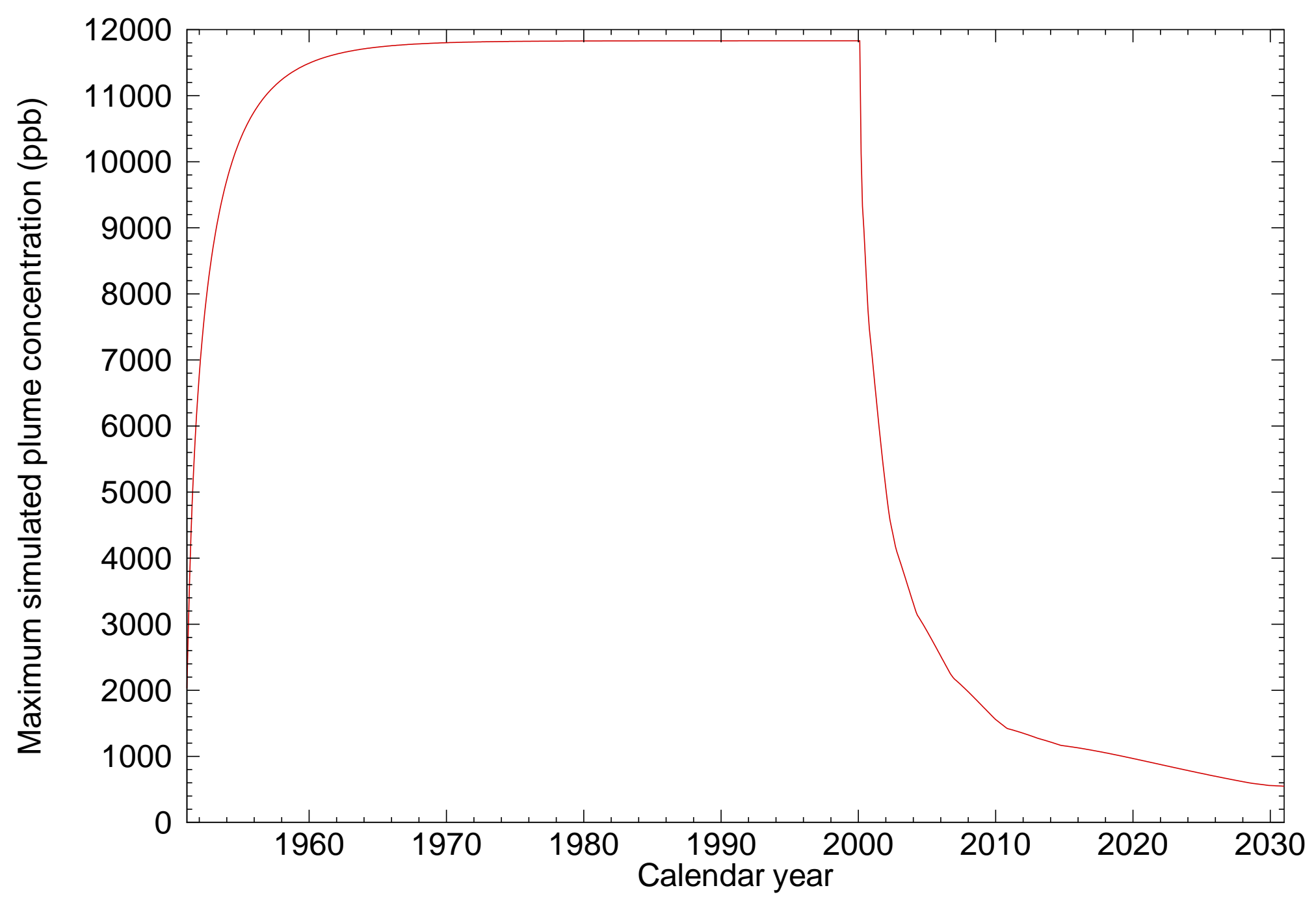

Figure 5-14. Maximum concentration in simulated CBRP TCE plume through time. 
Vertically-averaged simulated concentration above CC1

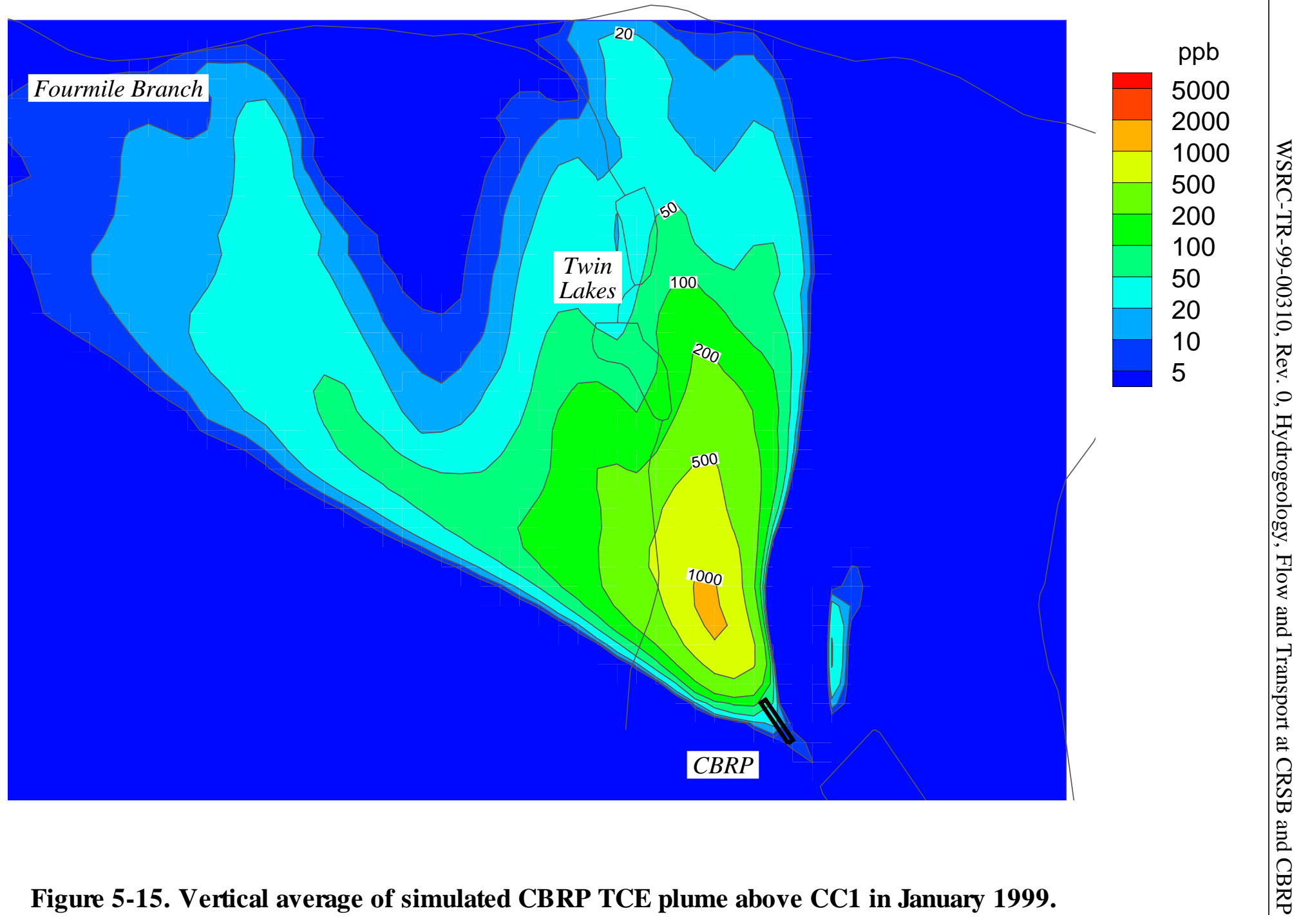




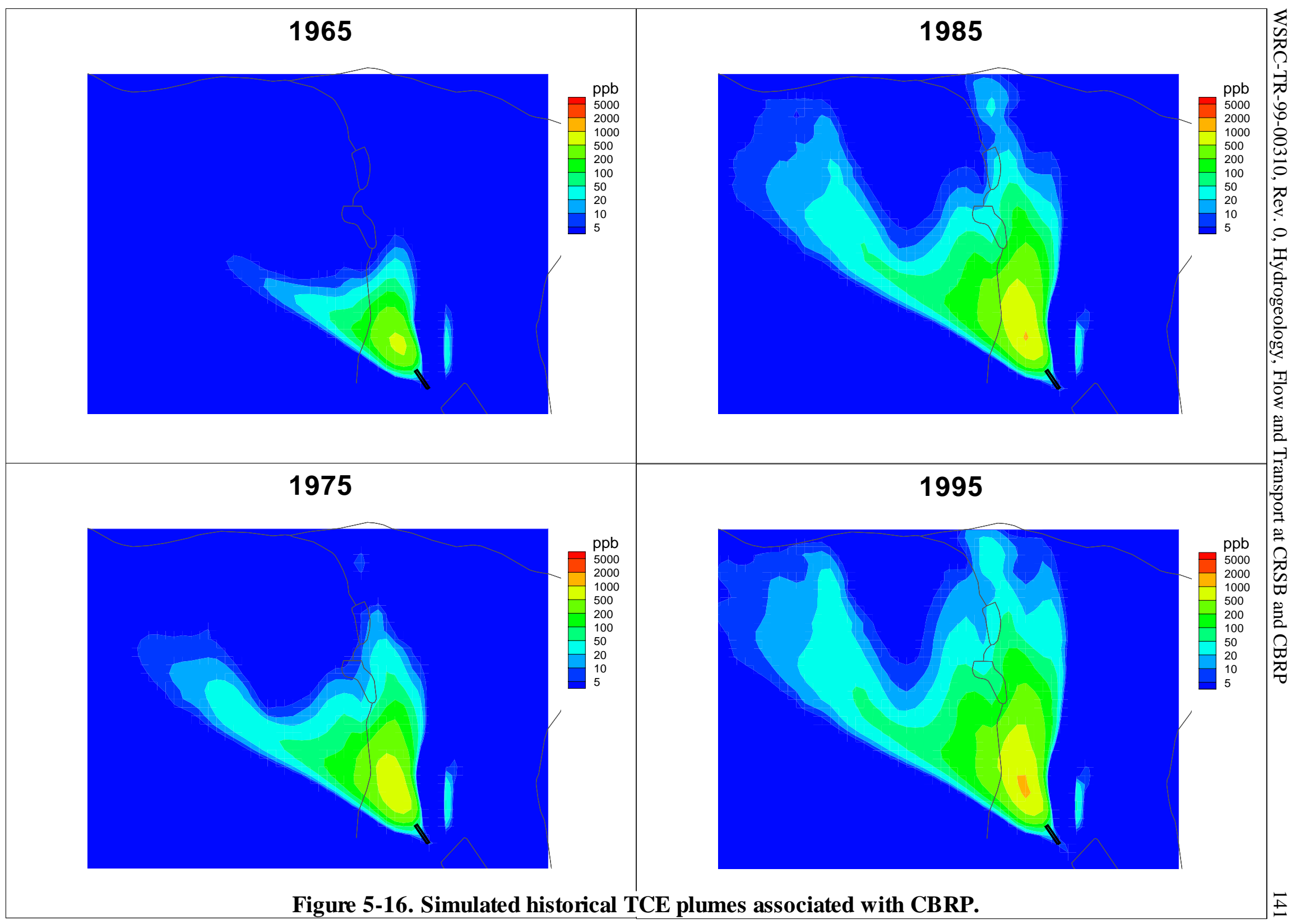




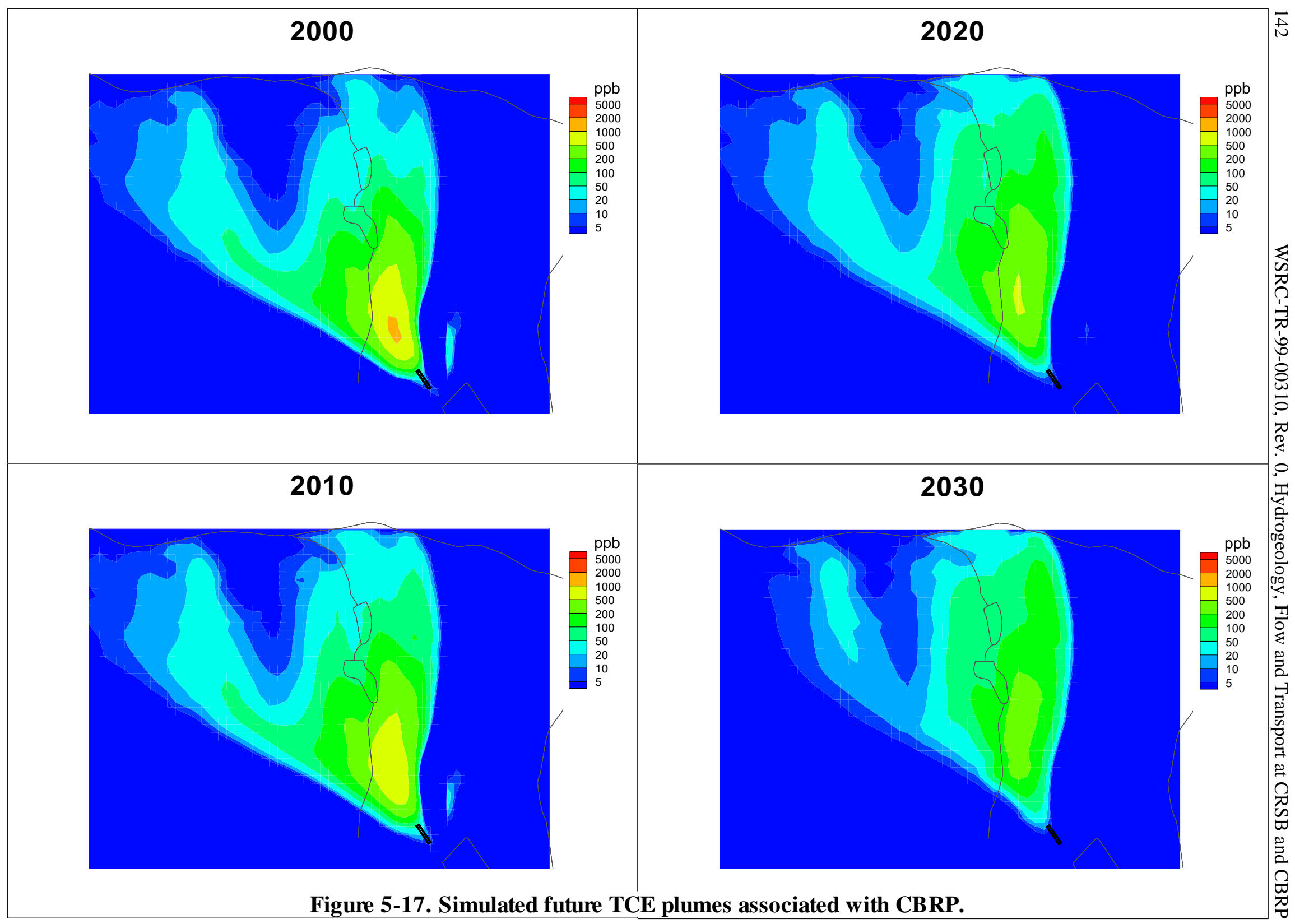


Table 5-1. Selected CPT sampling results for tritium.

\begin{tabular}{|c|c|c|c|c|c|c|}
\hline CPT location & SRS easting & SRS northing & $\begin{array}{l}\text { Interval } \\
\text { bottom } \\
\text { elevation } \\
(\mathrm{ft})\end{array}$ & $\begin{array}{l}\text { Interval } \\
\text { top } \\
\text { elevation } \\
\text { (ft) }\end{array}$ & $\begin{array}{l}\text { Tritium } \\
\text { conc. } \\
\text { (pCi/ml) }\end{array}$ & $\begin{array}{c}\text { Interval } \\
\text { thickness } \\
\text { (ft) }\end{array}$ \\
\hline \multicolumn{7}{|l|}{ Middle of plume: } \\
\hline CRSB-47 & 43419.51 & 67185.49 & 175.7 & 199.2 & 2348 & 24 \\
\hline CRSB-116 & 42794.74 & 67598.91 & 166.2 & 190.2 & 9111 & 24 \\
\hline CRSB-117 & 42698.32 & 67218.22 & 159.0 & 184.0 & 3165 & 25 \\
\hline CRSB-118 & 42707.65 & 66802.15 & 161.3 & 186.3 & 9000 & 25 \\
\hline CRSB-119 & 42193.79 & 67398.77 & 162.3 & 189.3 & 933 & 27 \\
\hline CRSB-120 & 42197.24 & 66998.48 & 157.8 & 179.8 & 4510 & 22 \\
\hline \multirow[t]{2}{*}{ CRSB-121 } & 42197.24 & 66601.65 & 157.7 & 182.7 & 3462 & 25 \\
\hline & & & & Average: & 4647 & \\
\hline \multicolumn{7}{|l|}{ Near seepline: } \\
\hline CRSB-122 & 41120.90 & 65679.58 & 133.4 & 164.9 & 3080 & 32 \\
\hline CRSB-123 & 41352.90 & 65585.04 & 138.7 & 163.7 & 1950 & 25 \\
\hline CSB-66A & 39622.52 & 65783.83 & 156.2 & 177.7 & 485 & 22 \\
\hline \multirow[t]{2}{*}{ CRSB-108 } & 40531.22 & 65154.15 & 150.2 & 162.7 & 562 & 12 \\
\hline & & & & Average: & 1519 & \\
\hline \multicolumn{7}{|l|}{ Lateral fringe: } \\
\hline CSB-58 & 41577.12 & 68028.13 & 180. & 181. & 2430 & 11 \\
\hline CSB-59 & 41295.09 & 67751.28 & 179. & 180. & 1980 & 12 \\
\hline CSB-60 & 40980.25 & 67502.28 & 164. & 161. & 1430 & 14 \\
\hline CSB-61 & 40668.70 & 67245.08 & 166. & 167. & 1300 & 10 \\
\hline CSB-61A & 40545.13 & 67149.46 & 168. & 169. & 1670 & 15 \\
\hline CSB-62 & 40344.02 & 67014.10 & 156. & 157. & 2410 & 18 \\
\hline \multirow[t]{2}{*}{ CSB-62A } & 40176.76 & 66913.72 & 151. & 152. & 1170 & 11 \\
\hline & & & & Average: & 1770 & \\
\hline
\end{tabular}


This page intentionally left blank 


\subsection{SUMMARY AND RECOMMENDATIONS}

\section{$\underline{\text { C Area Groundwater Model }}$}

SRTC has developed a groundwater model for C Area that:

1) Maintains consistency with the regional C, K, L and P Reactor Areas model described in Flach and others (1999);

2) Accurately reproduces groundwater flow directions from the CBRP and CRSB;

3) Matches targets for hydraulic head, recharge and baseflow within calibration goals;

4) Reflects aquifer heterogeneity as derived from CPT lithologic data; and

5) Provides the basis for subsequent transport modeling of specific waste units on a finer scale.

A flow model has been developed at a finer scale for the CRSB and CBRP that:

1) Maintains consistency with the $C$ Area flow model, and

2) Reflects aquifer heterogeneity as derived from CPT lithologic data.

Baseline transport models have been developed for the CBRP and CRSB waste units. These transport models accurately reconstruct historical contaminant distributions and simulate future plume migration.

\section{$\underline{\text { C-Reactor Seepage Basins (CRSB) Transport Model }}$}

Known tritium releases form the basis for the CRSB transport model. The average plume concentrations and migration path are in good agreement with recent groundwater sampling results. However, the thickness of the simulated plume exceeds the vertical extent of contamination as defined by the CPT data. Predicted tritium activity levels for 1999 are as high as $2000 \mathrm{pCi} / \mathrm{ml}$ at Caster Creek. Predicted seepline concentrations above the tritium MCL of $20 \mathrm{pCi} / \mathrm{ml}$ will be observed at Caster Creek for decades.

Recommendations for improving the CRSB model include: 
1) Restricting the vertical extent, and to a lesser degree, the areal distribution of the modeled plume. This will require refining the mesh and restricting the release area for the contaminants to be within the dimensions of the basins.

2) Implementing a "dual porosity" approach so as to improve the model's depiction of historical contaminant distributions and prediction of future plume migration.

\section{C-Area Burning/Rubble Pit (CBRP) Transport Model}

The CBRP transport model relies on the premise that NAPL is present within the vadose zone and serves as a source for the dissolved phase of TCE contamination. The model depicts this TCE source as a constant mass flux until implementation of SVE/AS remedial technology. The magnitude of the pre-SVE/AS TCE flux is uncertain, but is estimated (through model calibration) at $10 \mathrm{~kg} / \mathrm{yr}$. The model assumes that after remediation, all of the NAPL is removed and the dissolved phase remains in the source term. The current model further assumes that residual TCE contamination is not present in the vadose zone after remediation.

The predicted TCE plume for 1999 travels primarily along the north side of the Twin Lakes drainage at concentrations that are consistent with current CPT data. TCE concentrations are predicted to remain well above MCL for decades into the future.

Recommended refinements for future CBRP modeling include:

1) Modifying the model's conductivity field so as to eliminate TCE migration into areas south of the Twin Lakes drainage;

2) Replicating the observed vertical and horizontal extent of the modeled TCE plume by reducing numerical dispersion, and restricting the source area to the actual CBRP footprint;

3) Integrating CPT lithologic data into the plume model. This can be accomplished relatively easily through the construction of hand-drawn cross-sections of the plumes. Such cross-sections would use the groundwater data in concert with hydrostratigraphic interpretation and CPT lithologic data to depict a realistic plume configuration within the hydrogeologic framework. Detailed data on plume geometry will be a significant aid to model calibration. 
4) Incorporating quantitative estimates of residual contamination expected in the vadose zone after implementation of SVE/AS operations. These estimates will hopefully be based on the CRESP effort.

5) Implementing a "dual-porosity" formulation so that the model can better depict rebound phenomena in the vadose and saturated zones, and heavy plume tailing. 
This page intentionally left blank 


\subsection{REFERENCES}

Aadland, R. K., Gellici, J. A., and Thayer, P. A., 1995. Hydrogeologic Framework of WestCentral South Carolina. Report 5, Water Resources Division, South Carolina Department of Natural Resources, Columbia, SC.

Aadland, R. K., Harris, M. K., Lewis, C. M., Gaughan, T. F., and Westbrook, T. M., 1991. Hydrostratigraphy of the General Separations Area, Savannah River Site (SRS), South Carolina. WSRC-RP-91-13, Westinghouse Savannah River Company, Aiken, SC 29808.

Amidon, M. B., 1996. Re: Geotechnical Report (U), memorandum to G. Flach dated May 13.

Beard, D. C., and Weyl, P. K., 1973. "Influence of Texture on Porosity and Permeability of Unconsolidated Sand", American Association of Petroleum Geologists Bulletin, V. 57, p. 349-369.

Cahill, J. M., 1982. Hydrology of the Low Level Radioactive Solid Waste Burial Site and vicinity near Barnwell, South Carolina, United States Geological Survey Open File Report 82-863.

Camp Dresser \& McKee, 1989. Numerical Simulation of Groundwater Flow and Contaminant Transport at the K, L, and P Areas of the Savannah River Site, Aiken, South Carolina, Final Report, prepared for Westinghouse Savannah River Company.

Cooney, T. W., Drewes, P. A., Jones, K. H., Gissendanner, J. W., and Church, B. W., 1998. Water Resources Data - South Carolina, Water year 1997, Volume 1, U. S. Geological Survey Water-Data Report SC-97-1.

De Marsily, G., 1986. Quantitative Hydrogeology, Groundwater Hydrology for Engineers, Academic Press, Inc., Harcourt Brace Jovanovich, Publishers.

Denehy, K., and McMahon, P., 1985. Hydrologic and Micrometeorological Data for an Unsaturated Zone Flow Study at a Low-Level Radioactive Waste Burial Site, Barnwell, South Carolina, U. S. Geological Survey Open File Report OF85-476.

Environmental Protection Department and Exploration Resources, Inc., 1996a. Environmental Protection Department's Well Inventory (U), ESH-EMS-960488. Westinghouse Savannah River Company, Aiken, SC 29808. 
Environmental Protection Department and Exploration Resources, Inc., 1996b. The Savannah River Site's Groundwater Monitoring Program; Second Quarter 1996 (U), ESH-EMS960057. Westinghouse Savannah River Company, Aiken, SC 29808.

Fetter, C. W., 1993, Contaminant hydrogeology, Macmillan, New York.

Flach, G. P., L. L. Hamm, M. K. Harris, P. A. Thayer, J. S. Haselow and A. D. Smits, 1996. Groundwater Flow and Tritium Migration from the SRS Old Burial Ground to Fourmile Branch $(U)$, WSRC-TR-96-0037, Westinghouse Savannah River Company, Aiken, SC 29808.

Flach, G. P. and Harris, M. K., 1997. Integrated Hydrogeological Model of the General Separations Area (U), Volume 2: Groundwater Flow Model (U), WSRC-TR-96-0399, Rev. 0, Westinghouse Savannah River Company, Aiken, SC 29808.

Flach, G. P., 1998. Impact of F- and H-Area Pump-Treat-Reinject Remediation Systems on the Old Radioactive Waste Burial Ground (U), SRT-EST-98-154.

Flach, G. P., M. K. Harris, R. A. Hiergesell, A. D. Smits and K. L. Hawkins, 1999, Regional groundwater flow model for $C, K, L$, and $P$ reactor areas, Savannah River Site, Aiken, South Carolina (U), WSRC-TR-99-00248.

Freeze, R. A., and Cherry, J. A., 1979. Groundwater, Prentice-Hall, Inc.

Gelhar, L. W., 1993, Stochastic surface hydrology, Prentice Hall, Englewood Cliffs, New Jersey.

GeoTrans, 1992. Groundwater flow model of the General Separations Area, Savannah River Site, prepared for Westinghouse Savannah River Company, Project no. 3017-003.

GeoTrans, 1993. Groundwater Model Calibration and Review of Remedial Alternatives at the F- and H-Area Seepage Basins, WSRC-TR-93-384, Westinghouse Savannah River Company, Aiken, SC 29808.

Gruber, P., 1981. A Hydrology Study of the Unsaturated Zone Adjacent to a RadioactiveWaste Disposal Site at the Savannah River Plant, Aiken, South Carolina, M.S. Thesis, Geology Department, University of Georgia, Athens, GA. 
Gruber, P., 1983. "A Hydrology Study of the Unsaturated Zone Adjacent to a RadioactiveWaste Disposal Site at the Savannah River Plant, Aiken, South Carolina”, Role of Unsaturated Zone in Radioactive and Hazardous Waste Disposal, J.W. Mercer, P.S.C. Rao, and I.W. Marine (editors), An Arbor Science Publishers, Ann Arbor, MI.

Hamm, L. L. and Aleman, S. E., 1999. FACT (Version 2.0): Subsurface Flow and Contaminant Transport; Documentation and User's Guide (U), WSRC-TR-99-00282, Westinghouse Savannah River Company, Aiken, SC 29808.

Hamm, L. L., Aleman, S. E., Flach, G. P, and Jones, W. F., 1997. Subsurface Flow and Contaminant Transport Documentation and User's Guide (U), WSRC-TR-95-0223, Savannah River Technology Center, Westinghouse Savannah River Company, Aiken, SC 29808.

Harris, M. K., Aadland, R. K., and Westbrook, T. M., 1990. "Lithological and Hydrological Characteristics of the Tertiary Hydrostratigraphic Systems of the General Separations Area, Savannah River Site, South Carolina”. Savannah River Region: Transition Between the Gulf and Atlantic Coastal Plains, Proceedings of the Second Bald Head Island Conference on Coastal Plains Geology, University of North Carolina at Wilmington, pp 68-73.

Hetrick, C. S. and D. K. Martin, 1990, Radioactive releases at the Savannah River Site, 19541988 (U), WSRC-RP-89-737.

Hiergesell, R. A., 1997. Personal communication, January 6, 1997.

Hiergesell, R. A., 1998a. Regional Water Table Coverage of the Savannah River Site. WSRC-TR-98-00045, Rev. 0, Westinghouse Savannah River Company, Aiken, SC 29808.

Hiergesell, R. A., 1998b. Summary of Stream Baseflow and Water Table Work Conducted in Support of the R-Reactor and K-Reactor Groundwater Modeling Efforts. Westinghouse Savannah River Company Inter-Office Memorandum, SRT-EST-98-110.

Hiergesell, R. A., 1998c. Transmittal of Stream Baseflow Measurement Data, Westinghouse Savannah River Company Inter-Office Memorandum, SRT-EST-98-197.

Hiergesell, R. A., 1999, Preparation of Gordon aquifer regional potentiometric surface, InterOffice Memorandum SRT-EST-99-309, July 15. 
HSI GeoTrans, 1998. Groundwater Flow and Solute Transport Modeling Report; K-Area Burning/Rubble Pit and Rubble Pile, WSRC-TR-98-5052. Westinghouse Savannah River Company, Aiken, SC 29808.

Hubbard, J. E., and Emslie, R. E., 1984. Water Budget for the SRP Burial Ground Area, DPST-83-742.

Hubbard, J. E., 1986. An Update on the SRP Burial Ground Area Water Balance and Hydrology, DPST-85-958.

Huyakorn, P. S., Panday, S., and Birdie, T., 1991. Subsurface Analysis Finite Element Model for Flow and Transport in 3 Dimensions, Version 1.3, Documentation and User's Guide, prepared for Westinghouse Savannah River Company.

Huyakorn, P. S. and G. F. Pinder, 1983, Computational methods for subsurface flow, Academic Press, Orlando.

HydroGeoLogic, Inc., 1997. Groundwater Flow Model for the R-Reactor Area (U). WSRCOS-97-00006, Revision 0, HydroGeoLogic, Inc., Herndon, VA, 81 pp.

HydroGeoLogic, Inc., 1998. Groundwater Flow and Contaminant Transport for the RReactor Seepage Basins $(U)$, HydroGeoLogic, Inc., Herndon, VA.

Leeth, D. C. and Nagle, D. D., 1996. "Shallow Subsurface Geology of Part of the Savannah River Alluvial Valley in the Upper Coastal Plain of Georgia and South Carolina", Southeastern Geology, v. 36, no. 1, pp. 1 -14.

Looney, B. B., Grant, M. W., and King, C. M., 1987. Estimation of Geochemical Parameters for Assessing Subsurface Transport at the Savannah River Plant, DPST-85-904.

O’Brien \& Gere Engineers, Inc., 1991. M Area Post-Test Characterization Geotechnical Testing, File: 4998.007 \#2.

Orebaugh, E. G., 1987, Burial ground tritium plume investigation and interpretation of findings, DPST-86-591.

Parizek, R. R., and Root, R. W., Jr., 1986. Development of a Ground-Water Velocity Model for the Radioactive Waste Management Facility, Savannah River Plant, South Carolina, DPST-86-658. 
Siple, G. E., 1967. Geology and Ground Water of the Savannah River Plant and Vicinity, South Carolina, U.S. Geological Survey Water Supply Paper 1841.

Smits, A. D., Harris, M. K., Hawkins, K. L., and Flach, G. P., 1997. Integrated Hydrogeological Model of the General Separations Area (U), Volume I: Hydrogeologic Framework (U), WSRC-TR-96-0399, Westinghouse Savannah River Company, Aiken, SC, $118 \mathrm{pp}$.

Snipes, D. S., Fallaw, W. C., Price, V., Jr., and Cumbest, R. J., 1993. "The Pen Branch Fault: Documentation of Late Cretaceous-Tertiary Faulting in the Coastal Plain of South Carolina”, Southeastern Geology, v. 33, no. 4, pp 195-218.

Stieve, A. and Stephenson, D., 1995. "Geophysical Evidence for Post Late Cretaceous Reactivation of Basement Structures in the Central Savannah River Area", Southeastern Geology, v. 35, no. 1, pp 1-20.

Walpole, R. E. and R. H. Meyers, 1978, Probability and statistics for engineers and scientists, $2^{\text {nd }}$ edition, MacMillan, New York.

WSRC, 1993. Site Evaluation Report for the C-Area Reactor Seepage Basin (904-68G)(U), WSRC-RP-93-360, Westinghouse Savannah River Company, Aiken, SC, 29808.

WSRC, 1994, Phase II, Revision 2, RCRA facility investigation/remedial investigation plan for the C-Area Burning/Rubble Pit (131-C) (U), WSRC-RP-91-1122, Rev. 2.

WSRC, 1996. RCRA Facility Investigation/Remedial Investigation Report with Baseline Risk Assessment for the Chemicals, Metals, and Pesticides Pits (U), WSRC-RP-96-0012, Revision 1, Westinghouse Savannah River Company, Aiken, SC 29808.

WSRC, 1997a. General Groundwater Strategy for Reactor Area Projects, WSRC-RP-97435, Revision 0, Westinghouse Savannah River Company, Environmental Restoration Division, Aiken, SC, 29808.

WSRC, 1997b. Preliminary Characterization Report Phase I RFI/RI for the R-Reactor Seepage Basins/108-4R Overflow Basin (U), Westinghouse Savannah River Company, Aiken, SC, 29808.

WSRC, 1999. Technical Oversight to Install Reactor Piezometers (U), WSRC-RP-99-4021, Westinghouse Savannah River Company, Aiken, SC 29808. 
Yu, A. D., C. A. Langton and M. G. Serrato, 1993. Physical Properties Measurement Program (U), WSRC-RP-93-894, Westinghouse Savannah River Company, Aiken, SC 29808. 